a 20 


$$
\text { ช }
$$









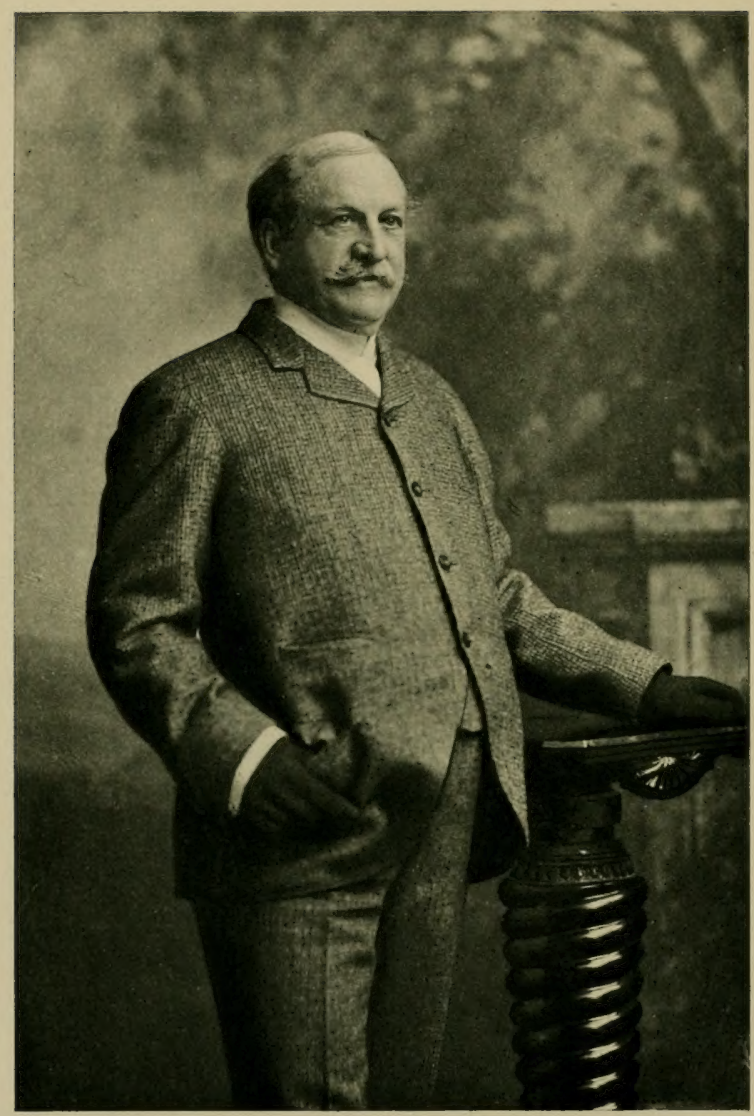




\section{Reminiscences of a}

\section{Spxитьтан}

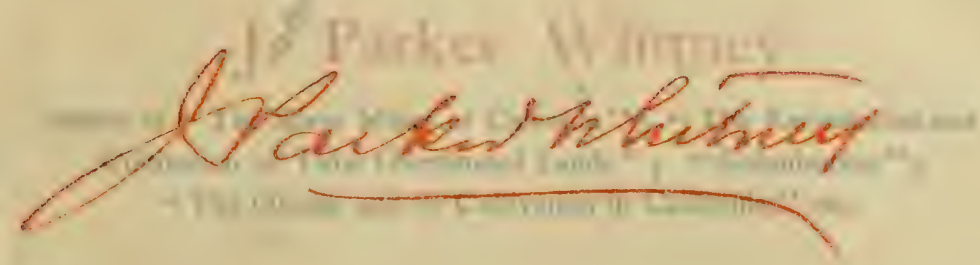

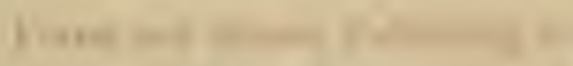




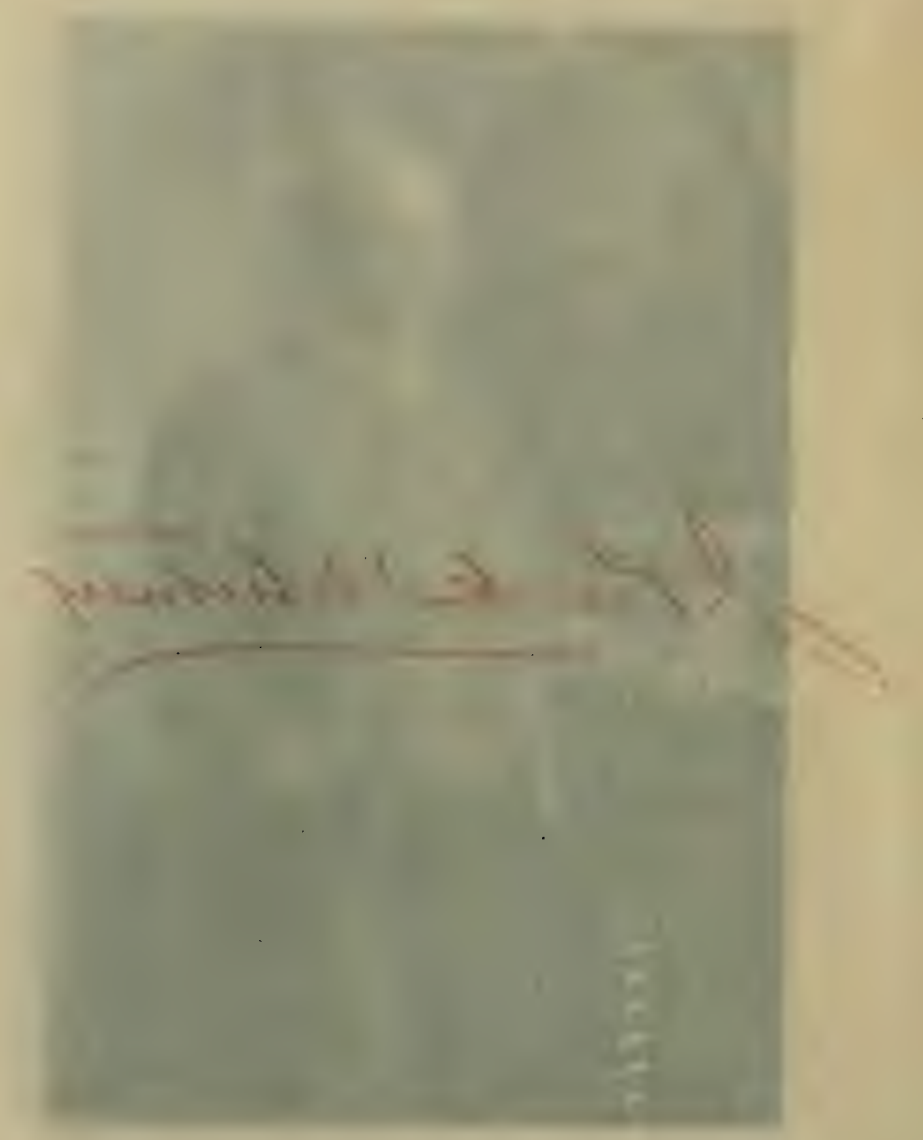




\title{
Reminiscences of a
}

\section{Sportsman}

\author{
By

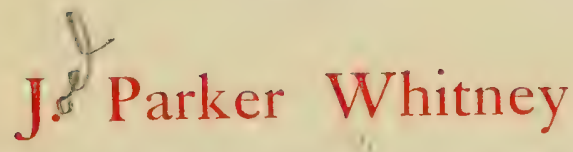

Author of "The Silver Mines of Colorado"; "The Reclamation and Cultivation of Tidal Overflowed Lands"; "Colonization"; "The Orange and its Cultivation in California," etc.

Forest and Stream Publishing Co.

New York

1906 


\section{$S K 35$ his}

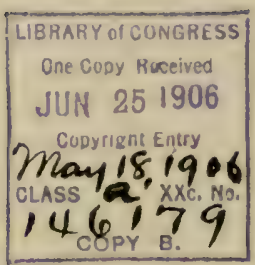

COPYRIGHT, 1906

BY

J. PARKER WHITNEY

$\therefore \vdots$

Tbe tanfckerbocker press, Wew Work 


\section{PREFACE}

SOME time ago I was induced at the request of a $S$ friend who had charge of a Sporting Review to write some articles for his paper.

These were continued longer than I had originally contemplated, and I give them with some additions in this volume.

From youth I have been.very fond of out-door life, and sports of all kinds, and although for many years engaged extensively in business affairs, I have never failed in giving way for these pursuits. Often such indulgence was seemingly to my disadvantage, but after half a century of gratification in this respect, I am well satisfied in believing I have no occasion for regret, for one cannot be deprived of enjoyments once possessed. I may add, that in pursuit of adventure, I have gained some important pecuniary advantages from opportunities offering.

The material in this volume of reminiscences is given in the order as first contributed, and not classified as it would be if written lately. 



\section{Reminiscences}

FISHING has been my predominating pastime, to which I have given more time and attention than to any other. At eight years of age, my father then being a resident of New Orleans, I commenced the gratification of this taste along the route of the Pontchartrain canal running from the city by the shell road to the lake of the same name.

I well remember now, after many years have elapsed, the exciting joy I felt when with my short rod and line I drew forth from amid the tree roots and rushes skirting the canal the small perch which I afterward fried in buttered tins by the kitchen fire. They tasted good, as well as the soft-shell crabs which I netted at the lake. And I remember how late on Saturday afternoon, after school, I prolonged my stay at the canal and lake until darkness came on and how frightened I became as I sped my way home at running speed, imagining the logs and roots by the canal to be bears or alligators, which abounded in the neighboring swamps.

At ten years of age I accompanied my two elder brothers upon a bear-hunting excursion in Texas, where my action was a minor part, but which resulted in the capture of two.

At twelve years of age I passed the summer near my birthplace in Massachusetts, where I spent the 
most of my time in trout and pickerel fishing. The former was fairly good, and the latter particularly so over the many ponds in the vicinity, and I trudged many miles for constantly alluring prospects at more promising ponds at a distance, when my results were less than I could have accomplished nearer home. Thus ever is the sportsman beckoned on to distant fields by the ignis fatums of expectation, and too often misled.

I remember one day, although I fished for pickerel generally with a skittering bait of frog's legs, of setting a quantity of lines off the dam of a mill-pond in the deep water, bai ted with live minnows, and making a great catch. I employed a number of boys who caught bait and attended the lines, using quite a number of winter lines belonging to my uncle. I paid the boys in fish, but had so many, and more than could be eaten at home, that, with the boys, I lugged them two or three miles to a neighboring hotel and sold them for a small handful of silver, which I was not above making pocket-money of, and' thought at the time I was making great headway in finance. This success inspired so much attention toward the pond that it soon became depleted of its precious holding.

I noted in later years, when visiting the trout brooks I fished that summer with tolerable success, that these brooks had dwindled away in volume and life, owing to the denudation of the forests, a result which is now clearly evident with many New England brooks, and which is shown on a larger scale in many countries and particularly in Spain in the country about Madrid, where are seen large bridges of iron and stone constructed in the sixteenth century over then large 
streams, which have now dwindled down to insignificant volume.

At the time of founding Madrid in the early part of the sixteenth century, which was centrally located in Spain, it was surrounded by forests of magnitude, all of which have disappeared from view. They were rain breeders and moisture holders, and with their loss the country became deprived of water supply and dependent upon irrigation.

I was strongly reminded while there, and viewing the desolate appearance of the environs of the city, of those about the comparatively treeless region of the city of Santa Fé in New Mexico, where one looks out upon a desert country, but scantily relieved by habitation.

I have noted in New Mexico the effect of forest denudation, as it is well known that at the time of the Francisco Vasquez de Coronado Spanish invasion in the early part of the sixteenth century, diverted from the Hernando Cortes, that considerable parts of New Mexico were forest-grown, now barren, which supported a much larger native population than found at the time of the acquisition of that territory by the United States in 1848 .

Frequent forest fires were the occasion which, even before the Coronado advance in search of the golden cities of Mexican tradition, had made prominent ravages, and diminished a population which had so far as indications show, been the most dense at one time in Northern New Mexico and Southern Colorado that existed upon the North American continent.

I have witnessed on the Estancia plains, and at Algodones and other localities in New Mexico and 
Southern Colorado, and especially about Algodones, comparatively unsettled now, the plentiful remnants of pottery, which can be dug up at about every shovelful, ancient watercourses, and adobe walls extending over many square miles, which have withstood the exposure of centuries. Ruins of stone watch-towers, and walls of immense community houses which were occupied by hundreds of the early Toltecs, remain as monuments of a departed race.

The question of forest preservation is becoming one of increasing importance, not only for game life but for commercial purposes, and the consumption at present by fires, and the demands for lumber, and especially wood pulp, and for domestic uses, is reaching alarming proportions; and in view of a rapidly increasing population on the North American continent, which in'another century will be four or five times greater than now, one may readily see that the question of wood supply and its preservation and cultivation will be one of vital interest.

At fourteen and fifteen years of age-in $1849-50-$ I had plentiful experience in Illinois over its plains and in the wooded region along the Mississippi River.

The State was then young, containing about one twentieth of its present population. Game was plentiful: bear, deer, raccoons, opossum, wild turkeys, water-fowl, prairie chickens, and quail. Squirrels were common about the hickory groves-gray, fox, and some black-and many of the gray and fox fell before my gun. I was very fond of this shooting, and I have never seen such quantities of squirrels elsewhere as were in evidence at that time. The fox squirrels here moved about the corn bins and fields, 


\section{A Sportsman}

while the gray I found more plentiful about the trees. These were more cunning in escaping observation, and had a habit of rapidly disappearing around the opposite side of the trees, where they were securely hidden from view, excepting a small portion of their heads, projecting for observation. As I would proceed around the tree I would be baffled by the alert squirrels, which would slip around in sequence with my movements.

It has been a mooted question if, in circling a tree in this manner, one who made the circuit with a squirrel upon the opposite side of the tree would actually go around the squirrel while going around the tree. This question I will leave open.

I soon overcame this difficulty by throwing a convenient stone or stick of wood as far as I could to the opposite side of the tree, which landing with some noise would almost invariably throw the squirrel momentarily off guard, when he would flash quickly to my side of the tree to investigate the probably new source of danger. The stay would scarcely be more than half a second, but sufficient in my preparedness to accomplish the end.

One day I bagged four grays out of five from a single hickory tree, which set the color vividly in mind. This was equalled on a moonlight foray we made with dogs for 'coons.

One evening we secured a family of four from a single tree where they had taken refuge. This hunting at night on horseback with dogs was a pastime much in vogue in my locality, and an occasional wildcat was taken in. I had an adventure with a 'coon one day which was not very pleasant. It was after a light 
fall of snow when I sallied out with axe and gun with two old, almost toothless dogs, the only ones about, and after tracking a 'coon to a hollow tree I proceeded to cut it down. No 'coon appeared, but while inspecting the upper part of the decayed tree a large one in its fright leaped out directly upon me. Down I fell in confusion, and upon me the 'coon and my two old dogs. To save myself I struggled hard, but the more I struggled the more I seemed to be the centre of attack, and it was an occasion of pleasant surprise when I succeeded in removing myself from the conflict, when the dogs had disabled the 'coon, to find I had received no bites, although sadly scratched, and with my clothing badly torn.

Wild turkeys abounded in the neighboring forest, and their gobblings could often be heard at a distance in the early morn. Small-brained and stupid as they are in many respects, they are nevertheless very quick and alert to take alarm, and when disturbed depend more upon their running than on flying. Stupid they are to allow themselves to be trapped in a rough structure of logs of a few feet in height, with open spaces between the logs, but not sufficiently wide to allow their egress.

One part on one side is left open to a height of twelve or thirteen inches from the ground. Corn is strewed plentifully on the ground inside of the structure and in a stringing way leading in several directions from it. The turkeys, reaching the corn leaders, follow up and unsuspecting enter the open way to the interior. After a while a sense of confinement occurs, and one flies up to escape between the logs, and, failing, gives panic to the balance, who lose their heads and all become frantic in their efforts to escape in the same 


\section{A Sportsman}

manner without seeking the place of ingress. This simple method is often followed with much success.

We occasionally in the autumn caught turkeys in the cornfields, where they were seen, attracted by the corn in husk pendent upon the stalks. This was done by chasing with dogs. Those hard pressed behind would take flight over the fence into the woods beyond, but those in advance would run to the fence to get through, and finding they could not, as the fences about the field were of rails zigzag and hog-proof at the bottom, in their close quarters running along the fence for possible openings and unable to rise abruptly enough to get over, would be seized by the dogs.

One day, while riding through the woods and approaching a settlement, I came upon a flock of turkeys which moved about near me with so little alarm that I thought it domestic, but having, after leaving them, a suspicion that it might not be, inquired at a near-by house and found that it was a wild one.

Prairie chickens were in great plentifulness at that time, and I can remember seeing the farm fences so loaded with them on frosty mornings as to be in danger of breaking down. On one occasion when I accompanied some older hunters upon the plains for chicken shooting we filled the wagon body with birds. The prairie chicken-pinnated grouse,-indigenous over a large area of the middle-western country of the United States, existed in great waves of plentifulness in the grain regions of Illinois at this time-1849, - which in abundance gradually diminished as the State became settled up, and the wave of plentifulness extended westward. 
In August, I880, when I accompanied a party from Chicago in a special sportsman's car into Minnesota and Eastern Dakota, we found this great wave of plentifulness there, and I remember my first day's shooting in the fields, when I bagged twentyeight birds. We had a box freight-car accompanying with ice, and were enabled to preserve our birds for forwarding back to our friends, though we ate a great many, as well as blue-winged teal, which were in force about the waterways.

The region was then settled largely by Danes and Norwegians, and entirely open from fences; and chicken hunters were in some abundance, to the annoyance of the settlers, who came out to warn us off their lands.

Dear Uncle Jake (J. K. Armsby, of Chicago, now deceased) was with us. How gently and well he would take the hurrying-out settlers as we drove up to their houses to ask permission to shoot over their lands!

Before they could speak a word he would conciliate them with a hearty greeting, and, having a big flask of whiskey and sundry small bags of smoking-tobacco and cigars, and children's picture books, he would have them placated before they could deny, which would result in a hearty invitation to make ourselves at home over the harvested fields.

THE pinnated grouse, or prairie chicken, is a purely indigenous American bird, and like the ruffed grouse, or partridge, commonly called, was formerly found extensively scattered over the continent, and 


\section{A Sportsman}

until late years existed upon some of the small islands of the Atlantic Coast.

The male bird has on each side of the neck a distensible orange-colored sac, which at mating season it inflates and dilates with a single booming sound, which is supposed to be very attractive to the gentler bird, or of challenging quality to its own kind.

When rising, it flies very evenly, presenting a fine mark for the sportsman. It has a most remarkable quality in its ability upon a comparatively bare ground to hide itself from observation. I have often observed this feature when without a dog I have marked down and followed a covey from a short flight. Approaching cautiously until I stood in the place of descent I have looked in vain for the birds which I knew were immediately about me, in fact almost under my feet, and I have stood for minutes gazing intently upon every nubbin of earth and spear of grass for a bird and not one could I see. Advancing, finally, one would fly up within a few feet of me, which would be a signal for the balance to rise, and off they would go from all around me.

I do not account the prairie chicken - though very tender and juicy when young-as particularly attractive for continuous eating, or in any way equal to the white meat of the ruffed grouse or partridge, which to my taste is superior, when in condition and well kept, to any bird in permanence of appetite hold. I have observed in the latter bird a marked difference in flavor, in favor of those of the Atlantic Coast over those of the Pacific. The latter I have often found too highly flavored with odors of various kinds arising from their particular food. 
The hen partridge is very courageous in the defence of her tender young, and I have more than once been amused by seeing my pet collie-who has more gentlemanly qualities than most dogs-chased out of sight by an enraged partridge mother, surprised with her young. Several times in the Maine woods I have warded off with my hands the sudden attacks of a hen partridge when so surprised, and in those solitary forests, where human beings are not often seen, I have often watched for some minutes a clucking cock partridge strolling about me, oblivious of any danger. They are often snared in Maine woods by boys, with moderately long poles with nooses attached. A feature I have also observed has been the increasing tameness of these birds about the sunset hour, more evident than at any other time.

For several years I had one frequent my fishing residence at the Rangeley Lakes, which would bud on the poplar in front, and made free with the storeroom and woodshed, and would feed on the food thrown out.

The spruce partridge of Maine is a bird still tamer than the ruffed grouse, but is not of pleasant flavor, though beautiful in plumage. It inhabits the swamps and spruce trees, taking its flavor from the latter.

The sage cock of the great plains is another of the grouse family which is not of agreeable eating flavor, being tainted with the brush it inhabits and feeds on. This bird has the distinguishing feature of being unlike any of the grouse family, being gizzardless, having no muscular development of that character, but a membranous sac in its place. 
The ptarmigan is, I think, the poorest eating of all the grouse family, not excepting the spruce grouse, and is as tame in its home localities as the latter. I have often encountered them in the heights of the Rocky Mountains. When with tender young chickens they will exhibit the actions of the domestic hen and bustle about in a similar manner, and I have taken up the young chickens in my hands and held them momentarily, while the mother would flutter around, and when let go would scamper away with the brood. I have seen them in the winter fly into uncrusted snow banks, when following them up would be a useless effort, as the ptarmigan will travel faster in a loose snow bank than one can dig after it.

I think our great American turkey may be put at the head of the "gizzard" family, and may lead the digesting procession, for it is capable of digesting about anything which enters its crop, be it vegetable, animal, or mineral. I have killed them when they were unable to fly from the weight of their overloaded crops, which swept on the ground as they walked, and have taken from single crops nearly a quart of acorns and other nuts, which would surely have been digested had the turkey lived.

The gizzard of a turkey is a wonderful piece of muscular mechanism of great power, through which the contents of the crop pass with the auxiliary grinders of stones, and the great muscular exertions of the gizzard pulverize the hardest acorns, some of them being as large as a man's thumb. Experiments have been tried with turkeys by setting stout needles in glass marbles, and being covered with dough these have been swallowed and, after a few days, have been 
recovered from the gizzard and found with the needles gone, and the glass pretty well worn away. The turkey may be regarded at the head for its digestive qualities, as well as for its delicious flavor.

Those were very happy days I passed in Illinois, to which my memory frequently reverts, and while many say they can only find pleasure in the expectations of the future, I find much in the contemplation of the past; and although I have committed many follies, and probably but few wise acts, I have certainly enjoyed life to a large extent, which more than balances the disappointments I have experienced.

Some twenty years after leaving there, being near the scenes of such pleasant memory, I procured a vehicle and drove over to the old Stone farm, butsic transit gloria mundi-what a shock I received! What an obliteration of all the old landmarks had occurred! The woods on the south had disappeared and in their place was an extensive cowfield intersected with trails, and beyond cornfields and houses. The dense forest extending to the river, and so wild and sombre I hardly dared to penetrate its far depths, had entirely disappeared. The brooks seemed to have dwindled away, and the old hickory trees of lofty height, which had appeared to me as sentinels of time, were gone. In vain I inquired of the settlers for the families of yore, only to be answered by the response, "Moved over to Missouri," or "Gone to Kansas." The tears unbidden came to my eyes, and I departed for new scenes, never to return.

After leaving Illinois, I attended school at Westminster, Mass., where I gave more attention to duck 
and partridge shooting and fishing than I did to studies.

One Ossian E. Dodge, a spirited singer, came along, accompanied by several minstrels of like character, whose concerts interested the town. One of their songs pertaining to California was given with great effect, of which I remember only the following lines:

'T is there they say the gold is found,

In great big lumps all over the ground.

Who'll go? Who'll go?

And we all sleep sound on the cold damp ground

Except when the wolves come howling around.

Who'll go? Who'll go?

\section{I thought I would.}

Another thing influenced me somewhat in that direction. One of the boys at school who had lately returned with his parents from California indicated a considerable degree of affluence by prodigally throwing oranges at some of the boys, who so assented for the privilege of keeping the oranges thrown. How slight are the circumstances which seriously affect our lives!

In $185^{2}$, at seventeen years of age, I arrived in San Francisco with my double-barrelled shotgun, a revolver, and a large, double-edged knife with a blade thirteen inches long, made from an old sword my elder brother had acquired in the Mexican War of 1846-47. I made a long passage of $\mathrm{I}_{42}$ days around Cape Horn, a monotonous trip diversified occasionally by catching sharks when becalmed in the tropics, spearing porpoises, and trolling for bonita and dolphins. Off Cape Horn, where sea birds were plentiful, we caught 
several varieties, and one day I caught a barrelful of cape pigeons, so called from their resemblance to that bird, but web-footed. These afforded several good meals for all hands, and they seemed very good eating at the time. I caught these with a long line, to which was attached a good-sized morsel of salt pork, below which extended a string of hooks on a strip of wood, on which the feet of the birds became entangled as the vessel moved on. This was a base and unfair method, which I now regret.

I landed in San Francisco well armed, but comparatively penniless, ten cents being all of my remaining capital of sixty dollars I had started with; fifty-nine dollars and ninety cents having been diverted by poker games, in which I was initiated by several young men on the voyage at one-cent ante and ten-cent limit.

An unfortunate incident occurred in connection with a family of Braggs, who had engaged passages and had their baggage aboard our ship, by being left behind. Our ship was delayed in loading for several days after the date fixed, and this family, depending upon its being still longer delayed, were visiting in an adjoining town and overlooked. The family sailed two weeks afterwards for San Francisco in a succeeding ship of the same line.

When we pulled in at San Francisco, Mr. Bragg was on the wharf awaiting our arrival, having been in the city two weeks before our arrival, our ship being a month longer in passage than the one he sailed on with his family. On this following ship, which had been loading some time before our ship sailed, he had loaded all of his goods in trade, valued at $\$ 10,000$, consisting principally of furniture, giving 


\section{A Sportsman}

up that business in Boston in view of continuing it in San Francisco. He had insured it against loss, but upon being left behind rescinded his insurance to save the premium, concluding, as he should take passage on the same ship with his family, that in case of shipwreck resulting in the loss of his goods he would probably with his family be lost also, and have no advantage from insurance. When the ship conveying him and his family and goods was entering the Golden Gate entrance to the city, it struck on a hidden rock, and sunk beneath the water a total loss, although all the passengers and crew were safely landed. Poor Mr. Bragg shed tears as he related to me his tale of sorrow, and I expressed much pity and sympathy for him; what became of him afterwards I never knew.

San Francisco, at that time, was a bustling city of some 30,000 inhabitants, and it was the flush period of the State, when money was plentiful, as well as the comforts of life. The latter were expensive, but money flowed freely and business was driving. Open gambling was at its height, and one could go through the centre of several blocks in the large gambling halls by crossing the streets. These saloons were ornamented with spacious bars, from which the plungers were supplied with free drinks, and soft music was dispensed with free hand. Side tables were supplied with free lunches, and all possible aid was extended to the sturdy miner, with his bag of gold dust, to induce his belief that the true Eldorado had been finally reached, and that he was a prominent stockholder and director in it.

The awakening was sometimes abrupt when he 
discovered that his interest had expired, and that his orders at the bar were ignored. Surprised and dispirited and restricted to free lunch, a conviction gradually formed in his breast that his experience had been a dream, and that his wakefulness should consist of another turn at the sluice boxes. Fights and murders were common; forty murders were said to have been committed in San Francisco in $185^{2}$ and only one murderer hanged-José Fornie, whose body we on the good ship Polynesia saw hanging in plain sight on Telegraph Hill the day we rounded the Golden Gate to dock.

Times were stirring; the roughs terrorized the citizens. A band calling itself "regulators" preyed upon the people instead of protecting them. One Casy, a gambler, shot in cold blood James King, of William, a prominent editor of the newspaper Bulletin, for exposing his crimes. Thugs and ballotstuffers controlled the polls. The bell tolled one day and the vigilance committee was formed of good citizens, with its mysterious and unknown secretary, otherwise than No. 33, whose mandates became law.

Arrests were made right and left; Casy and Cora were hanged; Yankee Sullivan, a noted prize-fighter and ballot-stuffer, committed suicide in his cell upon arrest, fearing that he would be hanged. Roughs were largely banished and prohibited from returning. I saw a lot leaving on a departing steamer-Billy Mulligan, Charley Duane, and others. I saw one day hanging on the hoisting tackle of a commercial house on a principal street the bodies of Whittaker and McKenzie, hung by the vigilance committee. Order was soon largely restored. 


\section{A Sportsman}

PENNILESS though I was, my heart was most courageous. Was not the world my oyster, as with ancient Pistol, and could I not open it with my sword blade? My three elder brothers had preceded me in 1848 and 1849 to California, and two were engaged in San Francisco in profitable business, and I had pressing invitations to join them, but I had no taste for it. Had I not my gun, and could I not have more fun to my liking in the country? Besides, I had visions of those lumps of gold said to be lying about at the mines, and hearing that near Auburn, in Placer County, over one hundred and fifty miles north of San Francisco, miners were making great pay, I went up there. How I got up to Sacramento -which was en route, up the bay one hundred miles distant-I cannot remember, but I do vividly remember that I walked up the distance of forty miles to the mines, and back to Sacramento again. The game I killed gave me welcome for meals and lodgings; welcome with the miners was more hearty in those days, when the professional tramp was unknown.

Apropos of tramps, no country is more infested with, or more favorable from its mild climate for, those vagabonds than California. Here sleeping out in the open or camping out is a pleasant pastime, where the blanket brigade is in great force, and where, owing to the thoughtless liberality of the people, it can depend upon liberal "handouts." The magnitude of this element was a legacy from the Civil War of $1860-65$, as all can note who remember how rare it was prior to the war. Of late it has been an increasing evil for which no remedy has appeared adequate, but will ultimately be relieved in the grand march of 
civilization as well as many other social evils by which humanity is retarded.

It will be remembered that the history of the animal man has been very brief compared with timea history which extends back but a few thousand years, and which by its extraordinary progress, despite the horrors of war and kindred demoralizing evils, will ultimately reach a level when a retrospection of present conditions will create surprise that beings so intelligent as those now existing could have submitted to such pernicious errors.

The country beyond Sacramento to the placer mines of Auburn was the most attractive I had ever or have since seen, comprising valleys and moderate hills grown over with groups of live and white oaks, inhabited by quantities of magpies, robins, larks, and other small birds. Beneath the trees were many quails and hares, with antelopes to be seen in the distance.

It was midwinter, yet the weather was bright and warm, and the temperature seldom fell to freezing.

How trivial are the incidents which oftentimes become important in our after lives! The casual observation of a fellow foot-traveller who walked on with me for a while, that it was an ideal sheep region, gave a color to my thoughts, which half a dozen years afterwards matured in my mind to the commencement of an industry there in which I engaged.

An elder brother had imported from Australia a few hundred high-grade sheep, of which all but one hundred and twenty had died upon the passage to San Francisco, and my brother's death occurring 


\section{A Sportsman}

shortly afterwards, I became interested in them, and they were placed on a tract of one hundred and sixty acres midway between Sacramento and Auburn as a desirable locality, and I have carried on the business until the present time in connection with other interests, and now after nearly half a century the interest has grown to an area of thirty thousand acres with nearly twenty thousand sheep.

My rambles about the mines and along the sluicing ditches failed to give me the welcome sight of nuggets I had expected my keen vision to discover. I had expected in my embryotic experience to sight a few of the size of hen's eggs, which might have escaped the observation of the miners, but afterwards concluded that I would be satisfied with some of more moderate dimensions, and finally thought I would be content with a few small ones sufficient to set off some scarfpins; but none did I find, and returned somewhat disappointed to San Francisco. Here I again declined opportunities for business, and frequenting the markets and game stalls more or less, which interested me more than anything else, I saw that game and birds, though plentiful, were fetching large prices.

Obtaining particulars of the sources of supply, I concluded that the situation was very favorable for adventures to my liking. Small table birds, quail, larks, snipe, robins, etc., were selling at five and six dollars per dozen retail; venison, sixty and seventyfive cents per pound; turkeys, ten dollars; chickens, three dollars; eggs, three dollars per dozen; butter, one dollar per pound. Here was my opportunity. I learned that the Santa Clara Valley, at the south end of the bay of San Francisco, was one grand field 
of birds; and that I could obtain three dollars per dozen for any kind.

Securing tag cards of the most promising city market-men, I directed myself to the port of Alviso, at the foot of the bay adjoining the promised land. Though my finances were low, not having even the fifty cents to defray my passage down the bay, I was exultant, breathing freely of hope and oxygen. The absence of base lucre was a trifling item when expectation loomed so brilliantly before me, and I had no difficulty in gaining the consent of the captain of the boat for a free passage when I explained the object of my trip, and he seemed very much amused at my enthusiasm.

My eldest brother, who was much opposed to my absurd scheme, as he termed it, and annoyed at my refusal to engage with him in business, learning of my proposed departure, made his appearance at the wharf just about as the boat pulled out, and vainly besought me to desist, which I positively refused, and also the pecuniary aid he proffered. As the boat parted from the wharf I stepped upon it, and my brother, as a dernier, tossed a twenty-dollar gold piece at my feet, which I promptly threw back at his own, and bid him adieu.

At Alviso, where I arrived before dark, I had no difficulty in getting credit for a good lay-in of powder, shot, and percussion caps, the latter then being in use for the muzzle-loaders in vogue, and in the latter respect I was equipped with my much-treasured double-barrelled companion, which that night I placed for safe-keeping under my pillow when I retired. I pushed on two or three miles from the 
village to a farmhouse, plentifully surrounded by wildmustard fields, where birds seemed plentiful. Here I engaged board and lodgings at eight dollars per week.

The following morning at daylight $I$ was in the fields, and early in the afternoon had about three dozen assorted birds which, tagged, went off that day to my market customer. This pastime I followed for several weeks, and although I did not average my first day's shooting, I rolled up a pretty fair profit over my expenses. The labor, however, I found rather wearing, despite my youth and activity; for, besides my necessitated walking in the fields, I had to give daily three or four miles more to the boat and back in forwarding my birds to market. This worked down my flesh somewhat, and though weighing now I 75 pounds, I was down to 120 pounds at that time.

One day a man came along bleeding from a broken head, leading a spirited mustang stallion, which had thrown him, and offered to sell it, with the ordinary Mexican saddle and bridle, for \$25. I had in view the joining of a small party of hunters, who were killing deer and elk in the neighboring mountains for the San Francisco market, so I purchased the horse, and in a few days joined the mountain party, which consisted of four, my interest being one half that allowed to the other hunters, and took up my abode with them at an open encampment in the mountain hills back of the San José Mission.

This party consisted of a German, a well-educated young Englishman, and two Americans. The latter were both from the State of New Hampshire, and 
one of them, Bennet, was a remarkably good and successful shot, very muscular, and noted for his adventures with and killing of grizzly bears. The latter were quite plentiful then in mountain regions about the Santa Clara Valley, in a region now taken up wholly by settlements, from which the grizzlies have been pretty effectually eliminated.

In the early days grizzlies were very plentiful about the valleys in the State, and John Bidwell, an early settler in the Sacramento Valley, gives frequent mention of them in his diary, lately published, and of often seeing from eight to ten in a single day. These grizzly monarchs, once so fierce and tenacious and disputants of the regions they inhabited, are now but rarely seen, excepting in menageries or parks, where they humbly accept peanuts and sweets from well-protected visitors.

Elk have entirely disappeared, and deer are restricted to comparatively limited ranges. Antelope, once so plentiful, are about gone. It was not uncommon in those early days to see large bands of elk frequently, and deer were so plentiful as to occasion cessation at times from shooting by the party I accompanied, from inability to transport to Alviso, the shipping station to San Francisco.

Our system comprised three pack mules, carrying six deer, and required two days for the trip, one day to Alviso, and one for return. These trips were taken by the hunters in sequence, in which I took part. I remained with this party for three months until the shooting season ended. When it terminated I had a small pot of money as my share, which constituted my commencement capital for the business 
of my life, and I had the pleasure at a later period of making a gift of $\$ 25,000$ to my elder brother, whose wants were greater than mine.

One of our New Hampshire men was a graduate of Yale College, and after the hunting trip I saw him engaged in the water business in San Francisco, he having acquired, with his capital obtained in hunting, an artesian well, from which he was distributing the water in carts.

Bennet was a remarkable character in his way, and never went out of the way to avoid a grizzly bear, and killed three during our excursion. He was of medium height and very muscular, and doublejointed. He was very jolly and good-natured when normal, but quick to quarrel when in liquor, which was not infrequent, and would often fill up on his trips to the bay, and on one excursion to the boat engaged in a terrific hand fight with the burly landlord of the Alviso Hotel, whom he laid up for repairs. He was a very fast runner, and claimed he could outrun a horse on a spurt. I saw him kill a large grizzly in an open wild-oat field one morning, which we observed at a considerable distance, as we arose. This, Bennet immediately claimed he would kill. The bear was dangerously situated for reaching and attacking, from being so far in the open without any sheltering trees or rocks. The bear was feeding upon wild oats, a favorite food.

After a hasty breakfast, we mounted and accompanied Bennet, and, being at the leeward, passed down a declivity and through some timber as near as we thought we could without being observed, and here separated. Bennet picketed his horse, and 
stripped down to his drawers and stocking feet, and, hatless, with his rifle and big knife, crept cautiously toward his victim. His knife was a feature, weighing three or four pounds-his grizzly knife, as he called it. It was somewhat like a cleaver, except that it was sharpened on the back from the point for three or four inches. He claimed that he was once followed up a tree by a wounded bear, where the latter could by reaching the lower branches lift himself up, and that he reached down with his big knife and lopped off the bear's claws, and mangled his feet so badly that he fell off the tree and quit the attack. Bennet based his safety largely-upon failure to kill -on his speed as a sprinter, and upon his knife as a last resort.

He soon passed out of sight, and after a little while I concluded to picket my horse and climb up a tree with my gun, from which I was able to view the field. I saw the bear was still feeding, oblivious of our approach and of Bennet's proximity, creeping through the tall wild oats and occasionally rising cautiously for a view. It was a bold, hazardous undertaking. Bennet kept on until he seemed to be within about sixty yards of the bear, and bruin was still unsuspicious. Here, cautiously peeping over the oats, he gave a light whistle, which brought the bear up and turning slowly around inspecting the origin of the sound. As he turned his side toward Bennet with his forepaws hanging down, the latter fired, and I saw the bear fall where he stood, and Bennet likewise dropped in his place for a moment, when he carefully arose to see if any advance had occurred, and, not seeing any, withdrew cautiously, keeping 
an eye on the spot the bear had occupied until he had placed himself some hundreds of yards off, where he waited from five to ten minutes watching any movement which might occur. Not seeing any, he carefully approached the bear, and found him in place, in the last faint struggle of life. It was a large bear in good fur and flesh, but no advantage was taken of either, as the fur was out of season, and the weather was too warm for holding the meat, and the latter was of little value at any season as an edible.

The grizzlies of the Pacific Coast, though larger than those of the Rocky Mountain ranges, and of great ferocity, are not considered as tenacious of life as those of the latter. Repeated instances are recited where the Rocky Mountain grizzlies after being fatally wounded have committed acts showing surprising vitality, mention of which has been made by all the prominent explorers of the West, commencing with the accounts of the famous Lewis and Clark expedition across the American continent in I804. It is related in the journals of that first exploration party to cross the Rocky Mountain regions that grizzly bears were an especial terror, which swam rivers and killed hunters after being shot through the heart.

Hunters have remarked the effect upon animals resulting from the active or passive condition the animal was in at the time of being wounded. A ferocious animal in pursuit of its prey, or in defence of its young, will exhibit a far stronger hold on life than when engaged in resting, or quietly feeding. It was quite common in the earlier days of California 
for the Mexican riders, fearless, and expert in the casting of the lariat, to surround a grizzly bear found in the open, and to hold him secure by numerous lines kept taut. Despite the enraged and frantic efforts of the bear, he became powerless while held by so many lariats straining in various directions from the pommels of well-cinched saddles, directed by the intelligent mustangs and their riders. When exhausted, the bear was despatched with a few shots or dragged to some stockade for a future bull and bear fight-a sport common in early days.

The Mexican vaqueros, in early days, when more plentiful than now, cherishing a prejudice and dislike of American invaders, and relying on their skill attained in the field in throwing the lariat, often illustrated their proficiency in this line by lassoing strangers who, travelling in an isolated manner, were met with. These, once being circled by the tightly drawn hide cord, were dragged from their footing or saddle over the rough ground until insensible, when they were despatched, and their bodies, after being rifled of any valuables, were thrown in some obscure place. Early Californians will remember the frequency of such events, and a number of bodies were found so despatched in the region about us during our mountain sojourn.

This condition put us on our guard in this respect, and I had reason to believe one day, when I was passing mounted along a valley trail of solitary aspect, that I was an object of interest to a rascallylooking Mexican, who was following me in saddle with his lariat coiled at his pommel head, and I increased my speed only to find that his was increased 
correspondingly, whereupon I quickly halted and put myself on foot beside my horse, and drew a bead upon him with my rifle; at which he, being beyond casting distance, made an extensive detour around and below me, and, after seeing him disappear on the trail below, I mounted and retraced my way back to our encampment. I was not much alarmed, for, though my rifle was a muzzle-loader, I had my navy revolver at my belt, with which I was tolerably proficient, and I felt quite competent to stand off one or two Mexicans before they could come within casting distance.

Some portions of the region about us were occupied as cattle ranges, and some of the semi-wild bulls met with were well to avoid. We made no scruples in knocking over a calf or a young heifer occasionally for a change of diet, at which no inquiries ever arose. At one time near us there was an encampment of cattle rustlers engaged in scooping small herds, which they would cut out and drive to the extent of a day's trip and turn over to an associate band, which in turn would deliver to another which would market or distribute at some distant point. Those camped near us were a bad lot, being mostly Americans from the Middle West, and our relations were the least friendly with them. They were soon after driven away by the settlers in the valley.

Some wild horses were about, but it was seldom that we saw any, and when seen they were a long distance away.

A few Digger Indians still inhabited the region, but kept well out of sight, although their presence 
was indicated by the removal of deer entrails, which was of frequent occurrence. This was evidenced by a clean removal of the offal, instead of being scattered about, as it would be by coyotes or other animals. The Digger Indian is pretty nearly extinct in the State now, and belongs to the lowest class of aborigines, living on roots, acorns, and offal of ancient date. I have seen them in some parts of the State, whole families, by the hour industriously engaged beneath some spreading pine tree, eating the meagre pit meats of the cones. The native clover flower tops are specially attractive to them, which they will sit among, and fill up their stomachs and skin bags. Grasshoppers they simply revel in and grow fat upon. Some years these are pests of such extent as to devastate large portions of the State, eating everything in sight, and are said to impudently ask the distracted farmer for chewing-gum and cigarettes. This season, however, is one of the Diggers' delight.

The oak groves about me now (my residence in California) were once the habitat of many Digger Indians. No monuments have they left, and all that tells of their existence are the thousands of mortar holes in the flat rocks, many of which still contain the pestles of rude form with which they crushed the acorns for bread-making. On many flat rocks there are a dozen or more of mortar holes, large and small, and some of them worn down to a foot in depth, and many hundreds of such mortar holes are to be seen within a radius of a mile from where $I$ am now writing.

Ten or fifteen years ago a small band of these Indians yearly came about here, but I have not seen 
any about of late. Capt. John, the chief of a small band, was an old friend of mine, but has evidently gone the way of his fathers. Attended by a small group of bucks and squaws he would regularly round up at my house, and, after a pleasant greeting, would accept an invitation to grub up with a load of cold meats, hams, bread, canned goods, etc., accompanied by sundry parcels of old clothes and hats; then, with an oleaginous smile over his swarthy visage, he would go to the clover valley below for encampment.

Almost weekly during Capt. John's stay he would call around for a personal interview, the substance of which was to procure a dollar to purchase powder and balls to kill wild-cats, in evidence of which he would pull out of his hunting and grub sack a badly worn pelt of some ancient nondescript of abnormal origin, which would immediately satisfy me with the importance of his request.

One of the first duties of Capt. John and his attendants was to disrobe and roll in the unctious mud of the mineral springs in the valley, and afterwards to sit in the sun on the ground for an hour or two coated with the mud, which was replenished at intervals by another application. The new portions added were poured down from the top of the head, and the appearance of those mud-cure zealots would discount any appearance yet given of the witches in Macbeth. From the mud to the water, and then with invigorated appetite to the clover beds, and in sequence to sweet repose, restful to the savage breast as to the luxurious visitor of modern curative stations, was a frequent act of our first families of America. Capt. John seriously assured me that it 
was a heap good for bone sick-evidently meaning for rheumatism.

These Indians often engaged in gathering grasshoppers when they were plentiful, in the following manner: First, by sinking a well-hole in a convenient locality, of some five or six feet in depth and of equal width, keeping it half full of water; then engaging all hands with bushes and tree branches in beating forward the grasshoppers on the ground toward and into the well, where they were soon drowned; then heating some large stones on a fire made for the purpose, from which the stones were rolled forward when sufficiently heated into the well, and the water, heating up, cooked the hoppers. When accounted done by the head chef, the hoppers were raked out upon the adjoining ground to dry; the latter effect being reached, they were then packed away in skins for use.

With them a good and prosperous season occurred when acorns and grasshoppers were plentiful. Even if the clover were deficient, it may be assumed that a good acorn stew enriched with a few handfuls of grasshoppers, and possibly a bunch or two of clover, would make a very appetizing meal for a Digger Indian as a change from pine cone, nuts, and ground squirrels.

Although the Digger Indians in the State are now reduced to very small numbers, there are still a good many of other tribes, more conspicuous than the Diggers were for intelligence, some of whom in early days were conspicuous for their opposition to the white invaders. A few thousand of these still exist, huddled together in small squads in various sec- 
tions, on lands which they do not possess. Neither the State nor the General Government has ever given them any reservation or aid. Some work and others beg, but are unable to compete with the white people in the economic struggle for life. Exertions are now being made for them by the Northern California Indian Association, in which I am interested, from which it is expected that the remaining Indians in the State will have their conditions improved.

$A$ FTER returning to San Francisco from the mountains, I found myself still indisposed toward the confining life of business, and besides I was more independently situated than before, having funds to my credit.

Australia was attracting attention, and several newly-made friends of mine were engaging passage in a ship about to sail for Melbourne, and I seriously thought of going with them, and selected a berth in the ship, but delayed in taking passage, and finally gave it up. I was largely influenced in this decision from the appearance of the ship, as it was a bad-smelling, unattractive old tub which gave me an unfavorable opinion of its capacity. Fortunate for me that I gave it up, for the ship was never heard of again after sailing, and it is not likely to be now, after the lapse of half a century.

I continued to frequent the markets and shipping. One day I saw on a freshly arrived ship from China a lot of canary birds, several hundred in a large cage on the cabin deck, which interested me, and which I found belonged to the captain of the ship, 
who had brought them over on a personal speculation, and that he had a lot of nested cages of bamboo to fit them out with for selling. I thought this a favorable opportunity for some work on my part, which ended in my purchase of the lot, birds and cages, for a thousand dollars, which gave the captain a good profit. I did not have enough money to pay down for the lot, but easily arranged with the rotund navigator to pay down what money I had and the balance in instalments, as I should take the birds away.

I then set at work putting up the cages on the deck, with a bird in each, and, with some assistance, carried the cages with birds to different stores I had arranged with, where they were exposed for sale, and being the first lot of this character to arrive in that budding city, my expectations were fully realized by rapid sales at full prices, and, although I shared liberally with the shop sellers, I considerably increased my capital.

Somewhat with the air of a capitalist, I then proposed to the market-man whom I had had dealings with in game that I should associate with him in his branching out in a more extensive business; that he should attend to the business in the city and I would go up to the alluvial lands in the bay, at the estuaries of the Sacramento and San Joaquin rivers where they debouched out over the flat tule lands, a great field for aquatic birds and salmon, and supply him with such products for sale. He was a pretty clever business man, but intemperate and inclined to various dissipations, which put me on guard, but he was willing, so we engaged. 


\section{A Sportsman}

Although the game season was practically over, no laws existed for preservation-or at least were not regarded-and eatable birds of all kinds were freely sold. Salmon were running, and were extensively seined by Italians and other fishermen, and a miscellaneous lot of fishes were netted, and birds were plentiful. I purchased and forwarded freely, and my man seemed capable of getting away with all I sent him, and generally at large profits. Salmon at times were so plentiful that I would occasionally buy them at ten or fifteen cents apiece and the city markets would become so glutted that the sales would be slow at five cents a pound, though the retail price would be a bit, or twelve cents.

One day I met a Scotchman looking for employment who claimed he was an adept at smoking salmon, and could at a moderate expense put up a smokingplant. I engaged him and proceeded in this line, to great advantage, as it opened a market in the mines where fresh salmon could not reach; but others soon caught on, and on a more extensive scale than mine, and selling prices fell off. In fact the business of my associate began to diminish in profits, and considering his habits, as prosperity seemed to increase his extravagances, I concluded to pull out, which I succeeded in doing with my full share of profits, which augmented my capital considerably. I concluded to retire and return to Boston by the Nicaragua route, where I arrived after a stay of a little less than a year in California.

The familiarity gained with the overflowed lands. of the Sacramento and San Joaquin rivers led to some. extensive reclamation works of mine in later years. 
I established my residence in Boston for a series of years, though I made five round trips to California before $\mathrm{I} 860$, and have since made those journeys over a score of times, besides eighteen round trips across the Atlantic to Europe. I crossed the great plains from the Missouri River to the Rocky Mountains four times from 1865 to 1867 , before the completion of a railroad there.

After my return from California I found a great difficulty in reconciling myself to the quiet of town life, however much the necessity existed for application to business pursuits, as my inclinations were strongly for adventurous ramblings. Always a constant reader, I found quite perceptibly to myself that my tendency was directed largely to the perusal of sporting articles, which conflicted with my resolutions to follow business affairs. This determined me to give up entirely the perusal of books treating of sporting and adventurous affairs, which inflamed my imagination with longings, and for several years I adhered strictly to this resolution.

From Boston I made frequent winter trips for pickerel fishing through the ice at favorite New England ponds, a sport which I enjoyed very much for a change, for, although the fishing was somewhat tame, the auxiliaries of the skating, tramping, and lunching by the open fires at the pond sides gave a pleasant relaxation. During the summers I gave much of my time to brook fishing in the White Mountain regions, where I felt that I acquired a dexterity in transferring the brook-trout to my creel, after scoring from three to five hundred in a day's fishing.

I am almost ashamed to relate what I would now 


\section{A Sportsman}

shrink from doing, even if I had the physical activity to accomplish it, concerning a score that I made one day on a branch of the Saco River. Then, before the railroad invasion and the present overrunning of the region about Conway and Jackson, the brooks were alive with trout.

There had been a rivalry among the comparatively few summer visitors as to a day's catch, and I then undertook to make a record-a foolish effort of young aspiration, and I will acknowledge the folly of such actions, although the demand for the delicate and toothsome brook-trout served to prevent any useless waste. I camped over night upon the stream with two comrades, W. T. Bramhall, of Boston, now deceased, and Gilbert E. Jones, of New York, at one time the owner of the New York Times and an enthusiastic sportsman, who also made a great record for the day. I commenced fishing at five o'clock in the morning and fished fourteen hours, until seven, scarcely waiting for any rest or lunch, and quit earlier than I should have but for a severe thunder-storm which wet us to the skin, and whose vivid flashes of lightning were required to get us out of the woods to our team at a neighboring town. My catch was seven hundred and sixty-eight trout, or an average of fifty-five trout an hour. In verification we counted over the catch twice upon our return to the Kearsarge House, where they were all consumed.

Such fishing was devoid of the pleasant contemplation of nature's attractions, which should be the main object of a sportsman's life, and an illustration of the feverish excitement which too often reigns within the human breast. I will own that many 
times in my early sporting life with gun and rod, I have overlooked the calm consideration I should have given preference.

In $1858 \mathrm{I}$ made in the winter an excursion in Maine to the Rangeley Lakes near the Canada line, which set a color upon my sporting horizon which has never been effaced, and since that period I have never failed, amid the cares of an active business life, to visit that region annually. Those trips at times have been difficult to arrange when I have been absent in distant places, but I have not failed in some month of each year since 1858 to rendezvous at the Rangeleys for from one to four and six months.

Reports of unusually large trout at those lakes had reached me for a year or two before the trip in December of 1858 , and some question existed if those trout were of the Fontinalis species, as they had not been so designated by a competent ichthyologist. I arranged with three friends equally interested in the subject for an excursion there, and after two days from leaving the Grand Trunk Railroad, breaking our way with team for forty miles through the snow, we arrived at one of the lakes of the chain. The last half of the distance through the forest was over an old logging road which had not been broken out that season, over which our progress was slow.

It was about dark when we installed ourselves in a dilapidated old logging camp at the foot of the lake, and the following day proceeded over the ice and its accumulated snow for a distance of six miles, camping at and making headquarters in a comparatively good logging camp by the shore. We had a single horse "pung" which we retained, sending 


\section{A Sportsman}

back to the last settlement, twenty miles distant, our double team sled, after depleting it of our personal effects, provisions, guns, lines, etc., with instructions to return for us in ten days. We had two guides, one of whom, Milton Cutting, for thirty-three years afterwards regularly accompanied me in all my trips to the lakes, until his advancing years compelled his retirement thirteen years ago, but is still living at about eighty years of age upon his small farm; I have since contributed to him the yearly sum of dollars equal to his age, and he has frequently remarked to me the increasing interest he has taken in growing old.

The ice was thick, but we soon got through it with our chisels, and in retired coves we caught bait of chubs and shiners, which equipped our set lines, and we found trout enough to enable us to fetch out upon our return to civilized regions between five and six hundred pounds in a frozen state to dispense among our friends.

Frozen fish in the ordinary sense is not usually acceptable, for one cannot tell how long it may have been between catching and freezing, or how effectual the freezing was, or if there may not have been a thawing out and refreezing, or exposure to sun while frozen, or various other causes affecting the quality. But any fish well frozen immediately after catching, and so kept without exposure to sun, and slowly thawed out in water in a cool place, will be found to retain all the delicate qualities of fresh life despite all prejudices to the contrary. In fact with care the most delicate fish, being cold-blooded, can be frozen up before life has gone, and so kept frozen for a period of days and then be thawed out 
to active life again, which I have often clearly demonstrated, but of which I shall not here go into details, reserving that feature for more particular mention and details of in extenso which will be included in the chapters I shall hereafter give concerning trout and its habits.

We found the trout plentiful and in fine condition, as they are apt to be in favorable waters beneath the ice in the month of December. In that month in northern climes they are in good form, and also in January, although from February and through March and April they are more sluggish, and very many go down to a depth and even into the soft mud at the bottom of the lake, where they remain in a semidormant condition, and those which continue to circulate about are by March comparatively slow in movement and appetite. As the weather moderates in April more activity is shown, and in May, when the ice generally goes out of the Maine northern lakes by the early part or the middle of the month, they are again in full activity.

The same semi-dormant feature is shown in all the varieties of the small fry of minnows and chubs, which can be plentifully caught with a small hook for bait for a few weeks after the ice makes, and in fact seem more plentiful after the first freezing over than at any time; almost wholly disappearing by March, and so difficult have I found it in the latter month to get live bait at the lakes that I have had to send out twenty or thirty miles at times to get bait from spring holes in the adjoining country. Then a good bait would be almost equivalent to a trout.

I have found that for the first week after the 
freezing over of the lake, when the fresh ice would not be more than two inches in thickness, phenomenal catches could be made of trout, as they would seem to be exhilarated by the new condition as much as lads would be with fresh skating. After ten or twelve days a noticeable falling off in activity and feeding occurs, which continues to increase until warmer weather comes.

We kept a careful weight of all our trout, noting down our catch each night, and we found our average to be one and a third pounds; our largest trout weighing a fraction over eight, and our smallest were a quarter of a pound. Upon our return to Boston I carried out several of the largest to Louis Agassiz, the distinguished naturalist and scientist, then living at Cambridge at the head of the Museum of Comparative Zoölogy, who made careful examination and pronounced them of the true Fontinalis family, but gave them a distinctiveness over other trout from their large size and habitat.

It would be difficult to find more beautiful and perfect trout than those of the Rangeley waters, or any of higher game qualities. At all seasons of the year they are full and superior in flavor excepting the meagre milters in the autumn, who may be well discarded from the table despite their brilliant hues. But the spawners even up to the time of their emissions are of delicate taste. I have since 1858 yearly fished these lakes, and taken many thousands of trout there, and have found them in the qualities I have designated more uniform than from any other waters, although no shadow can be cast upon many other localities. 
Maine is famous for its rivers, lakes, and ponds, which cover nearly one tenth of its surface. Its waters are mainly clear from excess of organic matter, where fish life is conspicuous for game qualities, which I have evidenced from personal experience at several score of localities in that State. It is not essential that trout waters should be of high translucent character as ordinarily supposed, and I have observed that trout waters of that character are generally lacking in numbers and size of trout compared with those more opaque and plentiful with infusorial life. The protozoa element is the basic foundation of fish life, and possibly of all other. It consists of an endless variety of Poligastrica and Rotatoria, white pulpy substances of life, which in favorable waters are of pin-head size, while the bulk are invisible to the naked eye. This infusorial element is the primary constituent essential to young fish life. The young trout or salmon, when relieved of the umbilical sac, is of minute proportions, and is unable to live upon the surface ephemera or food of after life, and subsists wholly upon the infusoria, as do all the small fry generally designated as minnows, of which there are a dozen varieties in the Rangeley waters. It is also the principal food of the freshwater smelts.

The profusion of small fish in the lakes supplying the principal food of the trout and salmon accounts for their number and superiority, without which they would be lacking, so that in reality the primitive cause is the infusorial element. This element abounds in all ponds, lakes, rivers, and even ditches where decaying vegetable and animal matter exists, and in 


\section{A Sportsman}

countless profusion. It is found in thermal springs, and rivulets flowing from snow-banks and glaciers, and in salt as well as fresh water. No form of life can be more universal and extensive, while of so minute a character in the sea and in many fresh waters as to require the strongest magnifying power to clearly observe. Even distilled water, upon exposure to the air, will exhibit the life. Freezing does not destroy it, nor will a deprivation of its watery element. It may be dried in the sun for many days, but its germ form when drifted with the dust to reviving waters will again take on active life. Ehrenberg, a celebrated German authority upon the subject, estimates the reproduction capacity of a single one to exceed $200,000,000$ in the space of a month. The variety of infusoria is extensive, more than a hundred being classified.

The remarkable feature of this element in the Rangeley Lakes, which by no means is limited to these waters, is the comparatively large size of the infusoria, which is undoubtedly gained by the large quantities of vegetable stain from the adjoining forests. The water is by no means clear, occasioned by the excess drainage from the woods. On a favorable day, with the sun's rays aslant, the protozoa element is clearly discernible to the naked eye. The most favorable occasion for observing it without magnifying power-for I have never applied the latter-is in the winter at the surface of a hole cut through the ice. Here, after a day or two, the larger infusoria will collect, doubtless attracted by the light, when those of a large size will be observed.

On this my first trip in the winter to the lake I 
was attracted by this feature while playing with trout through the ice. I would select a good locality where the water was not over eight or nine feet in depth, with a sandy bottom. Lying upon some blankets, with a single one over my head, and a hookless line with a small chub tied at the end and a sufficient sinker, I would bob for the trout, which after a while would come swimming along, and, noticing the bait, would, first indifferently, but afterwards more vigorously, engage with it. By drawing away the bait at the critical moment, after considerable teasing the trout would follow it up, and having a fair-sized hole of something less than a foot square, I would shortly get the trout up near the bottom ice, and finally, at a last excited dash, rapidly withdraw the bait entirely, with my hand at my side. The trout, following to the surface in its excitement, would for a moment be too confused to dive below, giving me in that moment the opportunity to rapidly put my hands below and cast him out upon the ice, unharmed, but much alarmed. This may appear difficult to do, but is really quite simple, and I have taken four or five trout in a forenoon from a single hole in this manner.

The clear, sandy bottom, and the thin blanket head cover, which by no means excluded the light, gave abundant opportunity to observe that the white specks at first mistaken for pollen, or other foreign intrusion, had a motion equal to several inches in a short time, and could be observed in the still water moving in various directions, some apparently with a revolving motion, and others without visible action. Many have advanced the spontaneity or protoplasm theory concerning the protozoa, which is a 
subject of much discussion, and lately a prominent German savant has advanced the theory that this element is the primitive origin of all life-all vegetable and animal-which now exists upon the earth. This is a somewhat startling theory, but that life must necessarily have started upon this once molten mass in a very primitive form is clearly evident, but how, may or may not be solved.

The snow was between two and three feet deep at the period of our visit, with frequent new falls, and I amused myself by making snow-shoe excursions in the forest about the lake.

$Q^{N E}$ day I came across the footprints of an animal, evidently of more magnitude than those made by a deer, and upon brushing out the tracks I found the imprint evidently of a cow or ox. I related this to the guides, and observed their immediate fixed attention and interest. They informed me no cow or ox could be found in the region about, and that I had certainly found a moose track, which we could easily trail, for he could not be many miles off, and that we would go after him the next day.

With lunch in our pockets we started at an early hour, fully prepared for a brush with a monarch of the northern woods. An examination of the tracks speedily determined the direction to take, and we had no difficulty in following them, although a foot of snow had fallen since the passage of the moose-for the tracks clearly indicated such to be the maker of the tell-tale guides. My men said his escape was 
impossible, it being only a question of time and distance, and that it would not travel far in the deep snow, over which we would proceed with little fatigue. It was some hours, however, before we grew warm on the trail, and about noon before we reached a place in the black growth where the moose had apparently yarded for several days, from which he had broken out upon our approach, before we saw him. At this time we redoubled our speed, and in less than a mile brought him at bay where the snow was too heavy for his further rapid progress. Here the moose broke down the snow about him to give himself foot room, and stood facing us in defiance. It was an exciting moment, and taking as careful aim as I could, I fired at his front. My shot seemed to have little effect, for, instead of breaking away, he commenced to increase his circle of enclosure, about which he moved with alacrity foreboding possible harm if he should charge us, and we each sought the shelter of neighboring trees to be prepared for his possible advance, and from here I gave a shot which brought him down on his knees, from which he soon toppled over, and the end came. It was a large bull and in good flesh, but bereft of horns, which had been lately shed. Skinning and dressing him, we hung up all to freeze excepting a hind quarter and a few parts which my men dragged on an improvised sled to camp. The following day the men returned for the balance, making two trips, and were enabled to portage all to camp on the long packing sled with which we were provided, but attended with much labor. We were three miles from camp, and did not arrive until some time after sundown. 


\section{A Sportsman}

No legal restrictions affecting moose or deer existed in Maine at that time, or if there were any, no attention was given, but game laws of late years have been rigidly guarded by wardens, under extreme penalties. Despite wardens and penalties, however, quite a sprinkling of killing has annually occurred in remote districts; but the general protection afforded, and the prohibition of market game selling, has had a very salutary result in increasing big game, especially deer.

Moose still are found about the lakes, in a forest yet unbroken which extends far into the wilderness. Though still scarce, they have of late increased, owing to the rigid enforcement of laws restricting their killing to a very short period during the year. A penalty of $\$ 500$ is exacted for this killing out of season. The killing of caribou is entirely prohibited at any time. Moose killing, when permitted, is confined wholly to bulls beyond two years of age. It has always seemed to me as if the moose were a modern survival of the ancient period, to be linked with the Irish elk and mastodon, and other prehistoric animals, and most likely with the musk ox, elephant, giraffe, and other unwieldy, cumbrous creations doomed to disappear before the progress of man, as we have seen the buffalo in our day.

I note quite recently the approaching extinction of the great Kadiak bear of Alaska-the largest in the world, exceeding even the mammoth grizzly of the Sierras, - which, inhabiting a limited district about the estuaries of the Karluk River, where within a few years as many as fifteen were sighted by an observer in one day, are now difficult to sight at all, 
and have by last accounts had their comparatively limited tract invaded by the ever-penetrating domestic sheep.

A conflict is now on between the sheep men and the bears. The latter evincing their taste for mutton in the waiting season for salmon-their main foodhave arousedt he former in defence, and the almost inevitable ,result will be extermination. A friend of mine has in his possession a Kadiak bear skin of enormous proportions, measuring from nose to end of body nine feet, with a width in the middle of eight feet. This may be a champion brown bear skin, and from one which was estimated, although not authenticated by sufficient evidence, at 2400 pounds.

I have measured an enormous polar bear skin which measured about the size of the Kadiak skin, but the polar bear does reach the weight of the grizzly family, being more sinuous in form.

I would not now hunt and kill moose in the snow, and at this time I look upon it with regret and consider it unworthy of selection by a sportsman unless necessitated by need of food, and confess to having aided in killing two others in a similar manner, as well as deer. There are many things in later life I have to regret of acts in early days, as I doubt not others have. Youth is more eager and thoughtless, and less governed by reflection than age, as eagerness overtops reason, and I fear there are many of mature age who fail to recognize the claims of right over inborn selfishness and destructive impulses.

I have occasionally met moose in the Maine woods. One day in a birch canoe, rounding a point on the Megalloway River, we ran close upon a large cow 
feeding on the lily pads, with her calf on the shore. She was just raising her head with a mouthful of pads, and stood motionless for a few moments gazing at our sudden intrusion, and then leisurely moved to the shore and with her offspring quietly disappeared in the woods. Another day, while being driven on a buckboard from the lake over a long logging road, and some miles from any settlement, we encountered a large bull feeding by the roadside. He exhibited no alarm, trotted along the road ahead of us for a quarter of a mile, and finally turned and faced us from the centre of the road. As the rutting season was on, and occasions were not rare when at that season moose had attacked teams, we came to a halt. Our horses exhibited alarm, and we felt some ourselves, and looked about for tree shelter in case of a charge. But the moose relieved us in a few moments by side-tracking in the woods, leaving us a free road. Another day I came upon a bull in the closed season for moose, but an open one for deer stalking, which I was engaged in, when the attitude of the bull convinced me of the prudence of retreating, which I expedited without delay.

It is quite common for bull moose at certain seasons to charge any one met with in the woods, but they are more easily evaded by one active of foot than one would suppose, by dodging around trees, and especially windfalls if they are adjacent, and I know several hunters who have escaped such attacks, and in some instances have been treed for hours. Moose have been known to swim out in the water and upset boats which have excited their resentment. 
A few years ago a friend of mine, Captain Barker, while running his steamer across a lake, observed a large bull swimming ahead for the shore, upon which he ran his boat up, and skilfully threw a noosed rope over the bull's horns, and conducted him to the shore, where, after some manœuvring, he managed to secure the end of the rope to a tree, and held the moose there for several days. He indicated a very fierce disposition, refusing to eat, and charging to the end of his reach any who approached his vicinity. After a few days' captivity he was released by cutting his rope with a knife fastened to a long pole, and the moose went off with his head-works adorned with a dangling tie of doubtful comeliness.

As I was engaged one morning on my first trip to the lakes attending alone a few set lines, I was startled in looking up to see three deer standing not far from me on the ice, but presently, after satisfying their curiosity, they trotted off into the woods below me. After my success with the moose, I was excited for a chase after the deer, as the snow was favorable, and leaving my lines I returned to camp a mile distant, when, securing my gun, hatchet, and a pocketful of lunch, I started back alone for the trail. No one was at camp but the cook, whom I told to mention to my comrades that I was off on a hunt, and to have no anxiety if I did not return at night. I returned to the trail from the lake, and followed the deer.

The days were then short, and the deer had travelled better than I expected they would, and it was near dark before I came near enough to get in a shot, which was harmless, while they were moving on with 
a speed increased by my near approach. If it had been earlier in the day my method would have been to press them to the utmost, but it was too late, and I had to look around for a camping spot, which I selected by a large dead fallen pine partly imbedded in the snow, but having limbs to pull upon for fuel. It was bitterly cold, as it had been growing colder all day, and somewhat below zero, as I found upon my return to camp. My hatchet was a poor substitute for an axe, but I managed to pile up a good supply for my night fire, but which proved insufficient before morning, and at three o'clock I had again to supply more wood, but considering it was the first night's camping in the snow, which generally is not so comfortable as the following, I got along by the fire pretty well, though not overburdened with sleep, and I felt quite ready to go on as soon as the first glimmerings of light appeared.

I found within a quarter of a mile where the deer had lain down in the night, and the beds had not frozen where they had rested, which was very encouraging, showing that their departure had but briefly preceded my arrival. They, however, got along better than I expected, and more than an hour passed before I overtook them, which was a signal for them to divide, as they usually do when hard pressed. Selecting the largest one I followed it for a mile or so before I brought him up, which proved to be a pretty good-sized buck, which I quickly gave the quietus to from my rifle. Giving the finishing stroke with my knife, I disembowelled him, hanging him up to freeze, and followed my trail back to the lake, between four and five miles. It was a bright, 
cold morning, and my steps were light from elation at my success, and I inwardly vowed I would have more of it.

That following night was the coldest we experienced on our trip, the mercury sinking down to twentysix degrees below zero, but we were very comfortable.

It is not so cold as it would seem, in the dry altitude of the lakes, $5_{500}$ feet above sea level, at twenty degrees below zero, when top coats are discarded in the woods and on the lake when knocking about. But when the wind blows it is another matter, and even with a gentle breeze at twenty degrees of freezing it will cut, and with a gale or blizzard at fifteen or twenty degrees below zero-which is not infrequentone must be well housed, or, if not, snugly ensconced in the lee of the gale in a deep sunken pit in the snow with plenty of firewood.

When camping out in the snow one hardly needs blankets, and it has not been my habit to pack them in many camping-out trips I have made in the winter, excepting sometimes a half one. I have depended upon keeping up a good fire all night, and of sleeping on a thick layer of hemlock boughs, where with feet to the fire and fully clothed, with sleeping-cap and ear-pads and thick woollen gloves, I have passed many comfortable nights, and my memory now often vividly reverts to the overflowing happiness I experienced upon those excursions as the most enjoyable of my life. 


\section{A Sportsman}

IN California, short as my stay was, I made some friends with whom for many years afterwards I sustained pleasant relations, all of whom have now passed away. It was in San Francisco I met Edwin Booth, at the rooms of a fencing master, where we were both receiving instructions, and formed a friendship with him which continued through his life. His father, Junius Brutus Booth, then near sixty years of age, was playing the last engagement of his life at the American theatre, and died that year, soon after, on a Mississippi River steamer. Edwin at that time had not appeared on the stage, excepting in a few minor parts, and I accompanied him at his invitation several times to witness the performances of his father. The latter was then exhibiting the peculiarities of his disposition, bordering on insanity, and accentuated by his over-indulgence in spirituous liquors. One night while playing Richard III. with his accustomed energy and fire, he left the stage and strode into a lower box adjoining, which was empty, and commenced singing a bacchanalian song to the boisterous admiration of the audience. Edwin, much chagrined, left my side for his father, whom he persuaded to retire, and after awhile to go on with his part in the play.

Another evening performance was the occasion of an amusing incident in one of the second-tier boxes occupied by a man and woman. The attention of the audience was drawn by the bibulous attentions of the man, evidently a returned miner with dust, and whose companion indicated her classification with the fanciful order; and' she seemed also under the effects of inflation. This side-play had been apparent for some time, while the actors were quite oblivious of the amused 
attention they were attracting. This became so conspicuous that finally Booth paused in the midst of the part he was playing, and, advancing toward the box and pointing his hand toward it, said, in his dramatic manner, which brought down the house: "When this sideplay is over, we will proceed." It required a little time for the audience to settle down to the regular bill of the evening, while the box players retired from the front to the obscurity of the rear.

I did not see Edwin again until a number of years had passed, when he had become famous, meeting him at the Tremont House in Boston, where I was residing, and there became acquainted with his wife, his mother, and sister Rosalie, and his brothers, John Wilkes and Joseph. John Wilkes Booth, afterward so infamous as the assassin of our President Lincoln, appeared to me as very companionable and cheerful, and many pleasant smokes I had with him, little suspecting that he would achieve the infamous notoriety he did. Though having some extravagant and peculiar ways, they were less conspicuous than those which Edwin evinced, or those seen in two others of the family. There was, however, a strain of peculiarity in the children, doubtless inherited from the father, which was quite evident. But if I had been asked to designate one of the children most free and sensible, I should have given John Wilkes, for despite his somewhat rollicking and moderately reckless way, he seemed very sensible. He was then playing an engagement, as was Edwin, in the city. Both were handsome and attractive, and received many missives from the gentler sex, who admired them. To those Edwin gave little attention, not only 
from having married a few months before, but from a disinclination and principle, as he on several occasions remarked to me, and that he immediately destroyed such letters, excepting in some instances, when he returned them with sensible advice to desist.

One evening while we were all after dinner in the Booths' sitting-room, a card was brought in from a young lady who requested an interview with Edwin. He smiled and told the boy to say he was engaged, when his wife, amused, said:

"No; let her come up. I am anxious to see what kind of young ladies are after you, and how she will appear with us all here."

So the young lady was brought up-and a blooming, exuberant young lass she was-ushered in, holding a large bouquet for Edwin. She was completely staggered by the standing committee which received her, and it was rather distressing to see her confusion and awkward dilemma and hear her choking words, that she had "brought the bouquet for Mr. Booth." Edwin accepted the flowers, and thanked her, at which she retired, with an experience unlooked for.

From Boston we all, including Walter M. Brackett, the celebrated artist, his wife, and young son,- - excepting John Wilkes,-made an excursion to the Umbagog Lake in New Hampshire, stopping at a moderate-sized hotel at Upton, kept by S. F. Frost. I remember his initials distinctly because we called him Superfine, at which he would give a winning smile. Dan Setchell, a comic actor and a particular friend of Edwin's, accompanied us; also some Baltimore friends of $\mathrm{Ed}$ win's-a gentleman and his not long-wedded wife. 
We remained at Upton about two weeks and had a merry time, making excursions on the lake to fishing places on an old tub of a boat which towed logs, proudly commanded by Captain Bennett, who had acted as guide in the woods with me on several occasions, and who now approached work about as near as he ever allowed himself. We made picnic trips to neighboring brooks, and altogether had an enjoyable season. Dan Setchell, a most amusing comic actor of good taste, never allowed the hours to flag, and the practical jokes he perpetrated are beyond recount. Poor Dan-unknown to present fame-was lost at sea not long afterwards, his ship going down in a gale with all on board.

Even then, the anti-liquor movement in Maine had commenced, and spirituous fluids were restricted from sale, but our landlord, Superfine, kept a private stock, limited, however, to one kind, and that was gin, which he had - of probably doubtful quality-in his cellar. Setchell made the discovery, and upon request Superfine brought up a medium-sized pitcher full, and placed it on the sitting-room table. The pitcher was a glass one, and had an appearance of containing the limpid fluid of the well. Booth had not yet come in, and Dan immediately conceived the idea of putting up a joke on him, as he would be likely to join in a pull on a somewhat neglected line. Obtaining an empty bottle he poured a portion of the gin into it, leaving the balance in the pitcher, and calling in Booth informed him of the discovered essence of juniper, and having lemon and sugar at hand prepared a gin toddy for good old times. We watered our toddies from an adjacent supply, leaving Booth to fill his from the pitcher on the table, 
which led him from the first taste to denounce the strength of his portion and to add more from the pitcher, filling his glass nearly to its brim. We had a difficulty in concealing our hilarity, while Booth, with a wry face, bolted the greater part of his glass, and declared by the horns of the sacred bull that if liquor restrictions in Maine resulted in yielding liquors of the strength of ours, there was still a balm in Gilead. Pretty soon he gave us a hornpipe jig in double time, and discovered our excess of mirth, which no longer had cause to be concealed.

Booth was in his prime, and constitutionally subject to varying moods; at times highly elated, followed by great depressions, and both would go to extremes. He fought hard against these tendencies, as against his disposition to indulge too freely in drink, and in the later years of his life largely overcame these features.

In fishing he would exhibit the impetuosity of a Petruchio, and this cost me several rods, which he broke into smithereens over small trout. He got in one day from a neighboring town a new fairly good bamboo fly rod, which I assisted him in setting up, arranging the reel and line and pliable soaked leader, and left him afterwards noosing on a scarlet ibis. The rod was lying on the dining-room table. I was no sooner out of the rooms on the porch, when I heard a tremendous rumpus in the dining-room, and entering found Booth flying about the room like a madman. He had left his fly hanging over the side of the table, which the half-grown family cat present, seeing, struck at with its paw, which the sharp hook caught in, and the frightened cat bolted under the 
table with rapid speed, breaking the rod tip and dragging the rod after, while Booth, crying "scat, cat," had no effect on the now crazed feline, which he was following after in great excitement at high pressure with adjectives of singular note. The sequel of this was the escape of the cat with the gaudy fly well hooked in its foot, and a well smashed-up rod. I was too much convulsed, with the others drawn in by the commotion, to render any aid, and Booth soon joined in with our laughter, confessing that his fishing experience was a failure, and that he would not have any more of it.

Booth frequently regaled us with stories of his stage experience, and I remember of his saying that his father was at one time very friendly and intimate with Edwin Forrest, after whom he was named, and how well he remembered the affection of Forrest for him in his youth, and how often Forrest had held him in his lap, and told him little stories, and how soon that affection passed away when he was reaching success on the stage, and commenced playing parts which Forrest considered his own; that this jealousy of Forrest's concentrated to an intense hatred, as indicated on several occasions afterwards. Forrest was a man of intense prejudices and dislikes, and yet of gentle and loving disposition toward those he trusted. He was as simple as a child in many ways, and as appreciative as a sensitive woman to delicate attentions. His physique was magnificent and powerful, and among the parts he played Othello would seem to have been more his prototype than any other character illustrated by the divine poet. He nourished an unfortunate inherent hatred and vindictiveness 
constitutional with him against those he considered his enemies, for real or fancied wrongs, and would go to any extent to express, unworthy of the natural nobility of his caste. I had occasion to meet him a good many times.

Edwin Forrest's most intimate and ever-trusted friend-in whom he placed implicit faith and who was worthy of it-was James Oakes, of Boston, now with Forrest gone away. He was a man among men, and of most sterling qualities and as true as steel in his friendship, which exceeded that of any man I have ever known for devotion, and for befriending those whom misfortunes had prostrated. I am familiar with numerous instances. No matter what occurred from poverty or disgrace to any friend of his, he held to his unwavering friendship to the grave, and would follow to the last rites of burial, and I have known him to lay out the bodies of his dear friends without aid from others. I felt great satisfaction in his friendship, which I clung to through his life, and which I now hold in pleasant memory. He lived at the Tremont House, where I resided for a number of years, and we were companions at the dining-table, and of many pleasant evenings pașsed in converse.

Forrest made frequent visits from Philadelphia, his home, to pass some days with Oakes, whom he so often told me was his dearest friend on earth, and whom he treasured beyond words. Mr. Oakes was cultivated in his literary taste, and was acknowledged as a forcible critic of dramatic works and dramatic renditions. Forrest told me that Oakes, as his dearest friend, was the severest critic on his acting of any he 
had ever encountered, and from him Forrest submitted to anything. I believe if Oakes had requested him to go out and walk around the block half a dozen times, without assigning any reason, that Forrest would readily have done it. The first time he came to visit Oakes at the Tremont House, I saw him seated with him at the table; I quietly took a seat at another, leaving the two loving friends together. Forrest observing this, from evident remarks of Oakes, asked him to invite me to my usual seat, which I afterward occupied and which led to further intimacy, and I was after invited by them to pass the evenings in Oakes's sitting-room, where Forrest made free in familiar conversation. Oakes often asked Forrest to recite, and read extracts from favorite authors, especially from Shakespeare, which Forrest was ever willing to do, and there was an interest and impressiveness in such which exceeded that of stage renderings. Oakes would sometimes require Forrest to repeat or read over passages several times, expressing his critical review, which Forrest would assent to with most gracious gentleness. The Lord's Prayer I have several times heard Forrest repeat with an impressiveness which a pulpit orator could well envy. Scriptural readings were favorites, especially the psalms and proverbs.

Oakes was well known in the earlier days from his critical articles and reviews over the signature of "Acorn," and his stepson, Thomas K. Batelle, was also a sporting writer of considerable prominence, over the signature of "Corinthian Tom." I knew him during my earliest days in California, and our friendly relations were continued:.. until his death, some twenty-five years ago. 


\section{A Sportsman}

The father of Batelle was a prominent shipping merchant of Newburyport, Mass., in the earlier days when that town was more prominent in extended commercial affairs than now, and from this town came several prominent men I have known: Caleb Cushing, George Peabody, George Lunt, and others.

Two sisters of Tom Batelle, Garafelia and Caroline, were the wives of the two Chickering brothers, Thomas and Frank, sons of Jonas Chickering, the inventor and large manufacturer of the Chickering piano. All are gone of whom I write, and it would seem that soon the reader and I will join the "innumerable caravan."

An incident occurred at Upton which had a sequel twenty-five years afterward, that I am reminded of. The young wife of Booth's friend from Baltimore, with her husband, were to accompany us one day on a general party picnic we were jointly to give at a brookside a few miles from our hotel. Some were to go in a large wagon, and the balance on horseback on the somewhat motley collection of equines found by Edwin in our vicinity. Mrs. Booth and Mrs. Brown, the Baltimore wife, Edwin Booth, Dan Setchell, and I were to go an cheval. It was with difficulty that we found two ladies' saddles, and they were not particularly attractive or efficient. But the two ladies were determined to go mounted and were both accounted good equestriennes. The wagon started off in advance, as there was some delay in getting on the steeds, and as the last of all was mine and the one preceding for Mrs. Brown, I assisted her to mount, and everything seemed to be tight and complete, but just as she started off, whipping up to overtake those 
in advance, her clumsy charger stumbled badly, throwing her over its head to the ground, where she struck heavily. I being the nearest raised her up, and, finding her insensible, carried her without aid into the hotel, and then, aided by her husband, to her apartment. The country doctor was sent for, and we were much alarmed, and gave up the excursion. The next day Mrs. Brown became the mother of a daughter, the arrival being somewhat in advance of expectations, accelerated by the unfortunate accident. Years rolled by, a quarter of a century, and although I met Mr. Brown occasionally I never saw his wife or daughter, until I met him one summer at a Long Branch hotel, twenty-five years after the Upton incident, when I learned of the death of his wife, and that his daughter, then married, was at our hotel with her husband. That evening I was presented to her as an old friend of her father's, and was left in conversation with her. After a while I expressed my pleasure in seeing her, not only as the daughter of my old friend, but from the fact of once having carried her in my arms, without ever having seen her, or having her see me, I most naturally experienced more than an ordinary satisfaction. She gazed upon me with a look of surprise and requested a repetition of my remarks, and afterwards said she then had doubts of my sanity. I told her briefly the story of the accident and of my carriage of her mother to the hotel and of the unexpected denouement.

$I^{N}$ these reminiscences I shall ramble more or less in the remembrances of the past as they arise in my 
mind, which if I do not take up as they come, will not otherwise appear, and though they may not be of general interest to the reader, or directly concerned with sports, will give me some satisfaction to recount.

I have noted the strong affection of some eminent men I have known for others, and often the opposites in dispositions - as of Booth for Setchell; of Forrest for Oakes; of Daniel Webster for Peter Harvey; and Henry Irving for Toole, the comedian. I was invited one evening in London to meet the two latter at a midnight supper at the Garrick Club, and I was struck with the particular affection which each bore toward the other. The affection of Webster for Peter Harvey is well known.

I heard the last great speech of Webster, in Faneuil Hall in 1852 , the year I sailed away from that port for California. Webster died that year. Faneuil Hall had been denied to him for some time owing to the sectional feeling which existed, arising from Webster's action in the Missouri Compromise bill, which Webster keenly felt. He had met with a carriage accident a short time before, from which he had not fully recovered. An intense interest existed in the city among the friends and admirers of Webster to hear this address, and the old hall was packed as a box of sardines. I accompanied my most dear and lamented friend Peter Butler, and Peter Harvey, each particular friends of the other, and the most dear friends of the immortal Daniel, to the small apartment where Webster sat alone in a large arm-chair waiting for the moment when he should be called to the platform. I had never seen him before, and I was awestruck with his grand and magnificent proportions 
and impressive features. His large dark eyes, well sunken over his prominent cheek-bones, imparted a singularly attractive effect. But his countenance bore a friendly greeting over its sombre sternness. I was shocked to hear Harvey familiarly say: "Well, Dan, how do you feel to-day?"

From our seats on the platform, where many friends of Webster were seated, we heard his last impressive words to the citizens of Boston. The standingroom of the large hall was entirely absorbed, and the standing audience, compressed so closely, took on a swaying motion from side to side which threatened the stability of the building. This continuing when Webster arose, he raised his hand, and impressively uttered the following words, which are about all I remember:

"Let every man stand still in his place."

The effect was instant. I have always had a love for oratory and good acting, and oratory often carries one beyond reason. I can imagine the ancient orators were remarkable for their stirring power, but I can hardly believe they surpassed those of modern days,- Chatham, Fox, Patrick Henry, Rufus Choate, Henry Clay, and our own orators of notein their specialties - of whom I have heard Wendell Phillips, John B. Gough, and Thomas H. Marshall, of Kentucky. I deemed them the most effective of any I have heard.

I was present at the first inaugural address of Abraham Lincoln, at Washington, of simple and heart-feeling words, which proved of no avail, and in several political meetings in Illinois I heard the combating stump speeches of Lincoln and Stephen 
A. Douglas. I have also heard Samuel Houston, in Tremont Temple, Boston, and frequently Edward Everett; also Henry Ward Beecher, Anson G. Burlingame, Salmon P. Chase, Caleb Cushing, Franklin Pierce, N. P. Banks, Gladstone, Robert Ingersoll, and others of prominence. I account Wendell Phillips-although by no means his disciple - one of the cleverest, and in language the most graceful and classical of orators I ever heard, surpassing the studied elegance of Everett in his seeming spontaneity and fitness of words, and I am doubtful if Cicero surpassed him.

I think for impassioned eloquence with lofty expression and personal magnetic power Rufus Choate in his address on Daniel Webster surpassed any I ever heard. This was delivered in the Revere House, in 1853, upon the anniversary of Webster's death, at a banquet given by the immediate friends and admirers in memory of that event. Choate had been a lifelong friend of Webster, and no one could have been selected more fitting for the event. Choate, of tall, thin, and angular form, with a countenance exhibiting the emotions of thought and genius in its worn and wrinkled features seamed with singular interlineations, indicative of his intense nervous-sanguine temperament, surmounted with a brow o'er which "the pale cast of thought" seemed enthroned, was confessedly the leader of the Massachusetts Bar, in effective force. In an intellectual sense I was an ardent admirer of the man, and I often stole away in busy hours to listen to and admire the illuminations and magnetic power of his persuasive eloquence in noted cases. 
One instance I recall in a criminal case where Choate was engaged for the defendant, which was of prolonged period, and excited an absorbing interest from the community, when his summing up of the evidence consumed several hours; and when the condition of the jury was plainly evident to the assemblage, being clear that eleven of the jury were for acquittal, while the twelfth sat stolidly in the front centre of the box, assuming an indifference unfelt by any other in the court. The case was one where the defendant had slain the seducer of his honor, clearly and premeditately. In the sense of the law it was a clear case for conviction. But who can account for the conclusions of a jury, which may act from sympathy, with its impulses strained to a forgetfulness of the mandate, "Thou shalt not kill." The twelfth juror became aware as all present that he was the conspicuous object of attention, and conscious that his attitude was apparent to his fellowjurors, as well as to the orator of defence, and that the latter's efforts were particularly directed toward him, and prolonged for his conversion. He was a singular man, of sturdy make-up and decided cast, with frontal head retreating to rear prominence; one of that sort of men who occasionally get drawn on a jury where the other eleven are wanting in good sense and reason. He had long since ceased to allow his sight to be obscured by the presence of the orator who held entranced with magnetic power the rest of the jury, and, affecting a stupid languor, sat with downcast head and eyes. Choate sought but one glance to hold with his conquering power, but in vain. It was an exciting period, a waiting one, to exhibit 
the mastery of one mind over another, of an effort to establish the line of transmission by the visual organ from brain to brain for the torrential outpouring, negatively diverted by the dam of obstinacy. The impassioned orator advanced and withdrew by turn over the open space between himself and the object of attack, vainly seeking an opening for his spellbinding power, until with a final advance accompanied with a flow of words in rapidity beyond the power of the stenographer's art, holding all present in breathless quiet, brought down his clenched hand with resounding force upon the flat bar by the downcast head which held the ransom of a human life. Thus startled, and much confused, the head quickly rose with an inquiring glance, which was fated to lose its domination, and the battle was won, for Choate caught it before it could slink away again, and held it with an intensity from which there was no mortal escape; and into the now receptive brain of his victim with a communication now established he poured forth a flow of alternate commanding and persuasive logic, which even the befuddled intelligence of his now terrified quarry could not withstand, coupled with the apparent conspicuousness of his position and a clear condemnation of his previously held attitude. There was little doubt felt when the jury retired what its conclusion would be, and a unanimous acquittal was soon declared.

The assemblage of 1853 at the Webster banquet on the first anniversary of his death was of most devoted friends of the departed statesman, and represented a distinguished element of advanced intelligence gleaned from the surrounding region. It was 
a question if any one could arise to the expectations of the event in a sufficient tribute to the memory of the departed one whose majestic presence and grand oratorical powers had been unequalled in the records of history - of one whom nature's mould had never given another of grander personification of manhood. When the moment arrived for the rising of Rufus Choate, all movement and conversation ceased and the stillness of expectation prevailed. All knew the careworn countenance of the orator of the evening with its graven lines, the brow whereabout struggled the furtive locks now silvering from time, the chin of firmness and classic mould; the mouth of expressiveness, from which issued the honeyed words of persuasiveness or those of disdain, contempt, or denunciation; the form moderately tall and spare, of nervous muscular build without tendency to fulness, quick in movement or quiet as occasion required, natural and unaffected, yet trained by years of active practice. The commencement was quiet, moderate, and of clear enunciation, of gentle tones seeking way into the hearts of the lovers of Webster, and finding place there; and thus on, with slowly increased recitations of moment, which found willing response. The orator knew full well the union he had found, without hand recognition. It was not required, for the words of the master mind in sorrow and regret and in sympathy and love and admiration were but the breathing form of united thought. And so on, with gradual increase of emotion so apt and natural that admiration of the orator was forgotten in the perfection of illustration.

There are many forms of oratory: The smooth 


\section{A Sportsman}

Addisonian flow of perfect English as rendered by Edward Everett, beyond criticism, possibly brilliant in a conservative degree, with well rounded sentences, accompanied by graceful gestures, but cold and emotionless. That of the often uncultivated and awkward delivery, but well founded on fact and reason. That of the extravagant type, which may interest and amuse. That of commonplace which in lack of evidence, manner, or fact is uninteresting. That of homely and kind delivery which touches the heart to its depths. That of Webster, the Great Expounder, in depth and comprehensiveness exhibiting the grandeur of the human mind to its extent, and whose very presence and simple words imparted an inexplicable interest. That of Choate, the creator of a school by itself, of magic power self-inherited; of form, head, and countenance indicating the restless and impetuous soul within; of imaginative mind in sentiment and tenderness; of analytical faculty and consecutiveness of illustrations; of education in the classics most exact: a rare combination of will power and thoughtfulness, and possessing that magnetic ability-if such we will call that mysterious and unknown power which exists without tongue, picture, or tangible evidence-to hold, enlist, and affect the hearts and minds of others. It is the innate offspring from hidden source which is not of thought and education and exists more or less in all, often unconsciously, and without which one cannot attain great power. This, in my view, was possessed by Choate to an eminent degree.

One can imagine the sublime influence of this sense from an orator possessing the general qualifi- 
cations of Choate, and for an hour the assemblage was held by an eloquence surpassing any it has been my experience to have witnessed. Perhaps I dwell too long upon this digression, and sometimes I think my receptive condition-being at that time in my teens-exceeded that of my present, but my recollection is vivid, and I would not deny myself the memory, and I can see as plainly as of yesterday the living countenance and animated form of Choate.

I think it quite probable that I was too receptive, for I am reminded of the intense interest I felt at that period in the dramatic recitations and acting of the famous French tragedienne, Sarah Felix Rachel, who visited the United States at that time, and the effect upon me exceeded any I have since experienced or approached by the representations I have witnessed of Ristori, Janauschek, Matilda Heron, Charlotte Cushman, and others of less note. Her fragile and delicate form, of pliant mould, and her pale countenance, of not particular impressiveness when at rest, became illuminated in action with the most intense expressions which only high genius (or was it talent?) could render. Her rest of classic cast, her movement of gentle or violent action ever graceful, her enunciation of sweetness or severity, although in foreign tongue, ever clear and penetrating, habitated her presence in my estimation beyond the possibilities of expectation, and I clung to her representations of Medea, Phrede, and other leading parts with a fervency and absorbism never since equalled. Rachel died soon afterwards in Paris at the age of thirtyeight, consumed, it is claimed, by the intensity of her own nature. 
In later years I have experienced the intensity of admiration and regard for the acting of the elder Salvini, whom I account the peer in natural presentation and reserved power of any other actor. In whatever play I have seen him, I have followed him with great interest, and I can hardly believe that Talma or Garrick could have been his equal.

I ET us return to the sporting line. In the early $\mathcal{L}$ history of Maine, game of the character now existing there was plentiful, and wolves were abundant, although they are now quite unknown except occasionally in the extreme northeastern part, and have not been known about the Rangeley Lakes for fifty years, which is rather singular, considering that such expansive forests abound, where the conditions are comparatively similar to those before existing.

Owing to the absence of protecting-game laws, and the ease with which moose and deer were killed in the deep snow in February and March,-becoming crusted over by slight day thawings and night freezings,--the slaughter was simple enough, and such killing was extensively pursued by the inhabitants, with a consequent diminution of both animals, and between the years $185^{\circ}$ and 1860 moose and deer became pretty scarce about the frontier settlements of the State.

This condition aroused public attention and game laws more stringent than before existing were enacted, and from i 860 deer became more plentiful, although slaughtering in the crusted snow was still continued to a limited extent in the outlying districts and by the winter loggers, but the laws became more drastic 
under the present commissioners who were appointed by the State, and who continue still in office.

Let us consider the benefits of protecting-game laws in a region where they have been of notable and conspicuous effect-more so, perhaps, than elsewhere in the United States; in an extensive region where a fair trial has been made, and where an opposition has constantly appeared, though of late much diminished, since the advantages of protection have become more apparent. A large increase of deer is now clearly shown in Maine, as well as moose, now appearing in districts from which they had become almost exterminated.

Especially in the department of fisheries have the advantages of protection been shown by the prohibition of winter fishing, and the limitation of the open season. These fish laws particularly have been in force against much opposition, from the objective element of the State, and this objective disposition is ever present more or less in all restricted districts from the unthinking and often reckless element. Such opposition comes largely from those who in reality have but little at stake.

The State of Maine can be cited conspicuously as one where efficient game protection has resulted in great gain, for the material benefit, not only for the State in its income derived from licenses, and money expended within its borders by visitors, but for the sportsmen who regularly frequent the lakes and rivers for fishing and the forests for hunting. It is estimated that from ten to fifteen millions of dollars per annum are expended directly and indirectly in the State by visitors who are attracted by the fishing 
and shooting advantages offered; and about twentyfive thousand dollars per annum are obtained from the sale of licenses, which funds are contributed toward the expenses of supervision, wardens, and the propagation of fish.

In 1875 there were but four lakes or ponds which contained land-locked salmon, which have now been introduced into more than eight hundred, and hundreds appropriate for black bass have also been stocked. The salt-water smelt, which is suitable for many fresh waters-although seldom reaching the size attained in the sea,- - is very generally distributed throughout Maine waters, and entirely throughout the Rangeley waters, which cover about one hundred square miles; it has furnished a new and very important source of trout and land-locked salmon food, and seems to be the chief food in the spring after the ice clearing. They are seen in large schools at the surface, of about two inches in length, and I have counted out from the stomachs of large trout and salmon as many as fifty or sixty from a single fish.

Under the intelligent action of the game commissioners, the breeding of trout and salmon has been most extensively prosecuted, and besides stocking home waters, young fry has been very extensively and freely distributed throughout the country, even to the Pacific Coast. In fact, the protection of game and sporting interests, prosecuted in the successful manner it has been, has largely increased the prosperity of the State, and United States Senator Frye, himself an ardent sportsman, in the course of a recent address, said: 
"In all the times of business depressions and distress, financial panics and consequent unemployment of labor, so seriously affecting the country, the State of Maine has suffered much less than any other State in the American Union, mostly, if not entirely, due to the large amount of money left there by the fishermen, the summer tourist, and the Fall hunter, the seeker after change, rest, and recreation."

The quinnat or king salmon of the Pacific Coast has also been introduced into the waters of Maine with success, and can now be caught up to a weight of ten or twelve pounds. The salmon is a freshwater fish, although its habitat is the sea, and after a sea life it cannot be transferred to fresh water without losing its prime qualities; if taken from the hatcheries as a fingerling or smolt and confined in fresh water it will become domesticated there and breed as other fish, but will never reach the size or the peculiar delicious flavor of the sea salmon. It will, however, retain the peculiarities of its congener in taking the fly and leaping from the water when hooked with all the game qualities of the trout, and in this respect is considered superior by many fishermen.

In some waters the land-locked salmon will gain more weight than in others. In the Sebago Lake, for instance, and also in the Rangeleys, they will reach a maximum of fifteen or eighteen pounds.

For a while moose practically disappeared about the Rangeley Lakes and one could travel long distances through the forests without seeing any or a deeryard. By a provision of instinct, which is indicated so prominently with many animals, the moose and deer will, in a region of heavy snows, select before 
the maximum of depth is reached, and the season when surface crusting occurs, a location generally in black growth where browsing is favorable, and yard, so to say. This yard is not particularly limited in extent, sometimes extending over several miles, depending somewhat upon the number of animals yarding. Here they will remain unless disturbed until the full snow season is on. The traversing of the yard keeps the soft snow broken up, and when the day thawings come along the indentations of the feet not only pack the snow at the foot imprints, but extend several feet outside, which, freezing, makes a stronger surface crust than over adjoining untouched tracts. Crossing and recrossing, as moose and deer will do a great deal of in a yard, imparts a favorable footing, and one passing over will readily discover that he is in a yard, though he may see no other signs of animal existence, and sometimes it requires a good deal of travelling to find the occupants when a yard is extensive.

The deer in a winter yard will evade the search by keeping out of sight, though their fresh tracks may be observed. If the snow outside is deep and heavily crusted they will show a great deal of reluctance in leaving a yard. Sometimes they will lie down in the yard together in the best place of shelter, and in such cases will allow the seeker to pass pretty near before taking flight, and will then perhaps round about in the yard, well aware of the difficulties which await them. Although accompanied by a dog, which will materially aid him, a hunter will often find great difficulty in ousting a herd of deer from a yard.

I came into a deer yard in the winter of 1859 - the 
first winter trip after the fishing excursion-in the early morning with my hunting guide, Nay Bennett, and his mongrel undersized dog-but clever with moose and deer,-and we spent the whole half-day searching for the deer which we had clear evidence were in the yard. It was some two miles long by a mile wide, and indicated the holding of a goodly number by the numerous fresh tracks, twig browsing, and other signs, and though we hunted industriously over it for four or five hours, no deer could we find, and as we had an objective point to reach that night several miles off, we concluded to lunch and push on. So, with a brisk fire, and some tea made with water from melting snow, and a rasher of broiled salt pork and bread, we relieved our somewhat fatigued legs by a rest.

We had one gun, a half blanket, and some pounds of bread and salt pork, some tea and a small pot and cups, extra thick socks, and a few other incidentals, including a few hooks and lines for catching trout through the ice. We were in a wilderness of forest where we could go a hundred miles or more without seeing a settlement, and were bound for Parmachene Lake, the headwater of the Androscoggin River, some thirty miles distant. What more could we desire than the prospect before us? I was reluctant about giving up further search for the deer, and not joining Nay in his accustomed smoke after eating, I left him to pack up our extensive holdings, with the gun, and follow, and taking a compass line in the direction we were to go, started on accompanied by our canine, which bore the euphonous name of Zip. I was about passing out of the yard north, when up sprang a dozen 
deer from their beds in the snow and in mass broke from the yard and down the somewhat steep hill in the direction I was heading. They were soon out of sight, leaving a deep furrow which Nay afterwards said looked as if a loaded cart had gone down there.

There was no time to lose as they should be hard pressed at the start before they could recover from the first fright, and settle down to a steady, moderate pace, or separate. So calling loudly to Nay, uncertain if he could hear me, I hastened on with Zip, who already was about out of sight ahead on the trail. He was a knowing dog, this mongrel Zip, who had served his apprenticeship for some years with Nay, his master being a noted hunter, and fonder of moose and deer hunting and life in the woods than work on the small farm he had at the Megalloway settlement. I was quite light and quick on the snowshoe, and I soon overtook and passed Zip, whose occasional slumping in the snow retarded his progress, but gave no cessation of his excited yelping. I soon left him far behind, but he had no discouragement in his bones, and afterwards came up in good season.

Not more than half a mile more did I go, before I had the deer in sight ahead; they, being confused and floundering in the deep snow, were still together. Pitiful sight was it not? I think so, but did not then, as I was too eager for the killing and fresh meat. But as I came up to them they parted in different directions, as was their habit when close pressed. Hastily selecting the largest of the herd for my particular attention, and to hold as I could only until Nay came up, I pressed him to bay, for he could not make 
progress equal to mine, so he beat down the snow about him and faced me, and I was holding him when Zip arrived full of fury and yelping.

My quarry upon this broke off again, when Zip, with still more frightful yelps, fastened momentarily on the rear, letting go in season to avoid the frontfoot strike so habitual with the deer at close quarters. A dog of this character is more efficient with moose and deer at bay, and in fact with bear or other large animals belonging to the dangerous class, than a large and courageous one depending upon his power untaught by experience, which often occasions his sudden exit from the scene, and consequent peril to his master.

I noted lately an account of the escape of a hunter in the mountains from a wounded grizzly bear by the active distracting work of a fox-terrier which accompanied him.

All the rest of the deer had broken away out of sight, and I saw no difficulty in holding mine until Nay should come up with the gun. But he was slow in arriving, and my buck kept moving along, and I kept after him, impeding him with $Z$ ip as much as possible, which worked him up into a great fury in which he would charge at his tormentor with a hissing sound, striking at him with his feet, which Zip managed to keep well clear of, but came very near being trodden under several times owing to the broken snow, which troubled him as much as the buck.

I worked up pretty closely with my cheering on, but thought prudent to have my long-bladed $\mathrm{knife}$ in hand in case I should receive a charge, and sure enough it came rather unexpectedly, and so 
suddenly that in my haste to avoid it, I locked my snowshoes and came down in a heap with the buck on top of me, but whose sharp feet I managed to avoid as he came down. Zip managed to get in on the rear, but I lost sight of him in the flurry, and had no way to avoid an up-and-down churning, excepting to throw my arms up over the neck of the deer, still retaining my knife in hand. In this situation I was lifted up and down very quickly several times with no ability to use my knife, and I saw that something would have to result very shortly, or I should be hors de combat, as my weight and strength seemed of slight avail in contrast with the apparently increasing strength of my adversary, who was hissing with fright and rage and whom I would have been glad to cry quits with, if I could only have been relieved from him. But the combat ended in a moment. I managed with my left arm hooked over the neck as I came down to get a handful of hair and skin, to hold at, and support my weight, and as quickly liberated my right arm and hand, and thrust my knife to the hilt in the chest of the deer at the neck. It was a lucky thrust, splitting the windpipe and heart, and we came down together, but I had to turn in the snow to avoid the ruddy flow from the nostrils of my dying victim. I had now to find if I had received any injury, and found I had but a few scratches to show, though my snowshoes had more serious damages, requiring more or less patching up during the balance of the trip.

When Nay came up we dressed and hung up the buck after taking a few choice strips for present use, and the deer remained for ten days or so frozen. 
Being but a few miles from a logging camp,we had the buck afterwards dragged out by the camp tote-sled, and on to the Megalloway settlement to take back with us, and its weight dressed up was one hundred and eighty-seven pounds.

Upon another occasion I killed with the same knife a still larger buck which came suddenly upon me in the snow when wounded. The conflict was brief, although several thrusts were required, and I escaped with but few bruises.

We pushed on for Parmachene Lake at the headwaters of the Androscoggin area of drainage, being situated near the Canada line twenty-five miles from the Megalloway River settlement, passing nearly two weeks on this my first snowshoe excursion to that region, which I was so much delighted with that I made four more excursions to the same region in the following winters with the same guide, meeting with many adventures and minor "experiences too numerous to give much mention of at this time. These were made in the months of February and March, when the snow was from four to seven feet deep on the level, and when the conditions were favorable for securing large game.

The method of camping out was very simple, and consisted of breaking up primarily the snow crust over a space of ten feet by seven, in a sheltered place where firewood was favorable, and then shovelling out the loose snow with snowshoes to within a foot or two of the bottom. Then a good mattress of hemlock boughs is laid upon the soft bottom snow, and a supply of dry pine and green birch or maple wood secured 


\section{A Sportsman}

at the side of the pit, and a fire made at the end braced up against a good-sized log of green wood.

Then comes a change of footwear, and the three pairs of woollen socks worn in snowshoeing, if wet, are hung up to dry, where they will without scorching, and then comes the delicious supper of broiled bird or venison or fish, with which the larder may be supplied. Melted snow supplies the water for tea, without lacteal or saccharine addition, and ye gods! what feasts can be taken in a comfortable snow pit by one who loves that sort of thing, with healthful rest, so gratifying to the fatigued hunter after a day's tramp. Then perhaps a fragrant pipe, sweeter than can be had amid the haunts of men, away and alone in the beautiful and enchanting forest. Think of it: No bells, or buzzing street cars; no evening papers, or postman; no notices of servants' quittance, or leaking pipes, discussion of gas bills or electric lights; no engagements for next evening-all away and forgotten, as one reclines upon the fragrant boughs, and watches the ascending smoke and sparks rising through the overhanging tree limbs toward the twinkling stars. Perhaps it may be stormy; then a shelter overhead of a few sticks and boughs, and the home grows more fascinating in change than when the sky is clear, so soul filling and rapturous that, in excess of joy, I have been inclined to leave it and roll in the snow and cry out in very fulness of heart, and as I look now, nearly half a century backward, my soul swells again to fulness, and the recollection drives away the forcing cares which unbidden would prevail. Happy days were those, perhaps the happiest of any.

How I would love, even now, to be thrown out 
into the depths of the forest again, and revel in the allurements belonging thereto. Would I enjoy it as much as before? Yes, I am sure I would, but the turmoils of later responsibilities are upon me, and it is more difficult to pull away. But how fragrant the memory! How it softens the asperities of life.

$W^{\text {ITH advancing years, one becomes more averse }}$ to the rough features of sporting life enjoyed in early days, and more reluctant to face the nipping cold, and rest upon unyielding beds, and so in late years I have reared comfortable abodes in the wilderness of the Rangeleys in Maine, where I could combine some semblance of personal comforts in the midst of the primitive forest. There I have made annual and sometimes prolonged visits for nearly half a century, where I have been able to observe the many peculiar features of the Fontinalis family, and to gratify my taste for solitary rambles in the unbroken forest, especially in the inclement seasons of winter when the charms dispute in attractiveness with all others.

When stalking deer in the open months of November and December-at which time the snow is likely to be moderately plentiful in Maine, through which, soft and yielding, even to a depth of two feet, the deer have no sort of difficulty in travelling rapidly, and at a speed beyond the possibilities of a stalker upon snowshoes-the stalker must depend wholly upon stealing upon an animal which possesses the sense of scent and hearing far keener than human possession, although it may be doubted if it has a 
superior perceptiveness in sight. All hunters have seen that wild animals will observe a moving body with interest if not suspicion, but if one stands perfectly still, at first, not being detected, wild animals will often approach very near, as I have repeatedly had deer, bears, and foxes do. Deer, seeming to be aware of this feature, will frequently stand motionless, supposing themselves to be unobserved, and will allow an intruder to pass very closely. Foxes, despite their cunning and suspiciousness, appear to be more dimsighted than other animals, and will come upon you very frequently in the fields about the settlements, when hunting field-mice, in which pursuit they seem to be wholly absorbed, and by standing still and imitating the faint squeak of the mouse, one may tempt them to approach within a few feet.

I wish I could do justice to the subject of deer stalking, but it has so many aspects, varying so in effect upon the appreciation and receptiveness of the stalker, that it is not likely that one's own views may be fully shared by another. Still, I can believe that with many, the enjoyment does not wholly consist in the killing of deer, although it is the primary object, but, as in fishing for trout, the auxiliaries are the attractive features.

There is a wholesomeness and vitality about the Maine forests in winter which is not found elsewhere. The cold, the ice, the snow, the changing rough weather, invite to the robust recreations of skating, ice-boating, tobogganing, and snowshoeing. They heighten the comforts of indoors. Restful sleep, appetite and digestion, and blazing birchwood fires. solve the question, "Is life worth living?" 
Whatever season it may be, the Maine forests are lovely, and it is difficult to say when they are the most so. One might say in the early spring, when the buds of the deciduous trees are expanding and the ferns and brakes unfolding, or when full-fledged, or in the decadence, when the autumnal tints appear; or in the winter, when garnished with wreaths of snow.

The period of falling leaves is exceptionally charming. As the leaves fall they exude the various odors of their belonging, so that one with closed eyes may tell the character of the prevailing trees. I have often thought of the pleasure I should take if I were blind in walking among the localities I am familiar with, when the pleasant recognition of well-known trees would guide my steps.

In my taste the late fall and first half of the winter dispute with any other season, and I am not sure if I do not prefer the rough and changing time of winter at the lakes, with its accompaniments, to any other. At least the summer is too short and the scene must lap over. Tell me not of orange groves and flowers, and vines with clinging clusters, but of the winter forest in its kaleidoscopic beauty, and of the lakes in their broad mantles of ice and snow. The singing of the wind around the tree-tops and the whirling flakes have more charm for my accustomed sight and ear than the cooing of the dove in midsummer bower.

There are scarcely any Maine forests, however tangled they may appear, which do not possess pleasant and accessible reaches of park-like valleys and hillsides, or rounded ridges of hardwood growth or pine, allowing comfortable travelling for the stalker. Possessed with the unerring compass and a tolerable 


\section{A Sportsman}

familiarity with the region marks, he advances upon the proposed line, which may include some miles of circuit. There must be an object in all efforts to give zest, whether we walk, drive, sail, bike, or shoot; somewhere to go, something to realize. So with the deer stalker, his primary object is to get deer, and it matters little in one sense if he succeeds or not, and the latter is generally the case. But if he is of an appreciative cast, the surroundings are inhabited with charming life and enjoyment.

Most stalkers will concede that at no time of the year are their rambles more agreeable than when the ground is half carpeted with the yellow, brown, and crimson leaves which announce the opening of the hunting season.

The deer are now found more in the open growth, and with the cooler weather range about extensively. It is the approach of the mating season, and frequent are the saplings with scarred bark, caused by the whetting of antlers preparatory to rival encounters. Here and there are bare spots and scattered deadwood which have been pawed in the impatient spirit of combat.

The deer-timid as supposed - is possessed of an indomitable and persistent courage in conflict with its own kind, and will fight to the extremity of weakness and even death before yielding. I have witnessed a good many scenes of this character, where the trampled ground and broken shrubs indicated desperate encounters.

At one place, a few miles from the lake, I witnessed in December a scene which indicated a meeting of particular ferocity. I had tracked a large buck 
through eight inches of snow. The buck had evidently found several others in conflict, and being a free lance, and at a free fight, had immediately engaged. The snow was completely crushed and tumbled over an area somewhat larger than an ordinary circus ring, and it was decidedly apparent that a stag circus of unusual magnitude had occurred without the supervision of a ringmaster, or the encouraging plaudits of spectators. I counted five departing trails, and the performance had probably terminated several hours in advance of my arrival. Probably one by one the vanquished had departed, until the acknowledged champion held the field. Such seems to have been the case, as the trails were diverging. One champion exhibited the hasty and ludicrous method of his exit by leaping over a broken tree six feet in height, when a projecting fracture had creased his body the whole length in passing, leaving a bountiful handful of hair and fragmentary cuticle in evidence. This might be accounted a feeling instance of the P. P. C. order of etiquette with the Cervus family. The trampled area was flecked with enough hirsute scrapings to fill a good-sized pillow, with occasional spatterings of scarlet coloring.

It is seldom that a buck, however large and savage, will charge a stalker when wounded, but occasionally - though very rarely-he will, and a friend of mine will carry the scar for life of a face disfigurement from a wounded buck he shot at, which came upon him with such sudden force that he had no time for defence, and was struck in the face by an antler which broke his jaw-bone, and stove out several of his teeth. The buck then passed on out of sight. 
I recall another instance of an experienced deer hunter of powerful build, a friend of mine, who had a wounded buck come upon him so suddenly that he could only seize him by the horns as they tumbled over together, and which he held down for some time, but found he could not get away from, for every time he loosened up, the buck would renew his attack, declining any retreat. For more than half an hour he carried on the struggle, and though powerful enough to hold the deer down, he felt his strength declining, while that of the buck seemed as much as ever. $\mathrm{He}$ had an ordinary pocket-knife which he finally managed to get out and open, and stabbed the buck with the short blade many times without reaching a vital spot, and began to despair that he would ever get out of the scrape, as he was becoming exhausted. He nerved up, however, and centred the work of his knife at the throat and finally severed the jugular vein, and the buck, fighting to the last, gradually weakened by the loss of life-blood, yielded to the inevitable. Bruised and bleeding, the victor related to me, he was so faint that he laid himself out beside the vanquished for more than an hour before he could wend his homeward way.

With the fall of snow the deer stalker finds new delight. With the luxury of well-stockinged and moccasined feet, he goes forth to new realms of enchantment. The atmosphere is of buoyant and stimulating energy. The arboreal and shrub life is invested with crystallizations of dazzling purity, each one being a marvel beyond the art of man. The consciousness of being alone in a wide expanse of forest, beyond 
habitations and the sound of human voice, is in itself for the nonce a sensation of relief.

The reaches of pine groves and of beech and of maple, all interspersed with birch-the loveliest tree of northern climes - are inspiring. They say:

"Come and explore me. We have waited long and you came not. Now you shall bear witness to our grandeur and solitude, and have contemplation. See in us the prototypes of your own race, how we rise and fall. We flourish in prosperity and topple in misfortune. We stand apart, some rugged and gnarled as some of your own kind, defying the wintry blast, but others are nurtured in protection. Some are comely and others scarred. See in us your own history, to start forth and bear and die. Your sun of light is ours, and the sky to all, and the air you breathe is our life. Yonder broad stump is the monument of a patriarch of old. There were giants in those days, but none now, for they have been taken to rib your homes and deck your ocean messengers."

At the hour of noon the stalker rests before a dead and broken pine, which with match and birch peelings is soon ablaze. His simple luncheon becomes a precious blessing, and may be followed by the incense of fragrant pipe. What more shall be required to fill the day's cup of happiness than the comfort of the home fire at night and the panacea of Nature's most enjoyable fatigue?

After my first winter fishing trip in 1858 to the Rangeleys I made perhaps a dozen more in succeeding years, generally in the months of December and January, finding much satisfaction in the change from the confinement of town life, with the attractiveness of 
taking such fine, large trout, always in good form, and surpassing all others of which I have known.

Despite the sometimes unfavorable weather, when storms and cold predominated, the pleasures and realizations of buoyant cheerfulness, appetite, and sleep well repaid all privations and inconveniences. Sometimes it was difficult to get there, owing to heavy snowfalls and unbroken roads, requiring two or three days from the settlement to get through and established. But this was the commencement of fun, of which there was no cessation. There were no settlements then within miles of the lakes we visited, and we had to haul in our supplies on bob-sleds. Sometimes the ice would be treacherous, and we would break through with our horses, but no particular danger attended this, though we once lost a pair of horses, which was occasioned by the carelessness of the driver, who ventured beyond the route which had been lined and tested by axe strokes. This was in early December when the ice was thin at places, and in this place of breaking through the ice all about was too thin to allow any leverage to pry up the horses so that they could be pulled out, and we had to abandon them as the weather was very cold, below zero, and darkness coming on.

We often got horses in over spring holes where the water below had cut the ice thin, and at cracks and blow-out holes. But it was a simple method the natives had, though not gentle. Always having ropes on the sled, a rope with a noose was thrown over a horse's head after it was detached from the sled, the latter being pulled back, seldom going in with the team. The horse, being well choked, swells up in the body, which prevents sinking. A stout pole, 
generally carried on the sled, is inserted under the body of the horse, which is pried up until a portion of the fore part lifts on the ice, and then all hands, pulling on the rope, slide out the horse on the stronger ice. If with a pair of horses, the method is repeated with the second, it being choked up to flotation while the first horse is being pulled out. Unless the weather is particularly cold, and if the horse is not in the water too long, it can generally get up on its feet. If not, it is helped up, and moved about until it regains some activity. Then harnessing up takes place, and we move on.

We never lost any horses, excepting in the instance mentioned. Although the treatment given seems rough, I have not known any injury from it, or even a complaint from the patients, who, doubtless, were grateful enough for escape from drowning by being thus promptly treated. It is needless to say that the equines employed on the lake roads are not up to the standard valuation of the pedigreed stock we often hear of, as frequenters of the lakes will readily admit.

To break in when skating or fishing is a small matter, and one crawls out without difficulty, and if the weather is moderate may go on, draining and warming up with active movement, but if the weather is about zero, one should seek shelter. The danger from breaking in when the ice first makes, and is thin, arises from the inability to find sustaining ice about the break. Then if one is without a long pole to lay on the ice to spread his weight over some space, he is in danger without extraneous aid, unless he is so near the shore that he can break ice to it.

The uniformity of thin ice is a feature of great 
danger, and to be most cautiously approached, and when travelled over should be on a line close to the shore. I have often gone up the lake shores for a matter of ten or twelve miles, impatient of reaching camp, when finding the ice thinner than expected, and unsafe for teams or even men on foot, had to keep along the shore ice on snowshoes, drawing sleds with long ropes behind. New ice is particularly tenacious, and although it will crack and seam, will, when no more than an inch and a half thick, readily hold up a man of ordinary weight, and a man on snowshoes can safely creep along on an inch of new ice.

The swelling and contraction of ice in changing weather gives a good many curious features. One day when several of us were proceeding along on the ice near the lake shore for camp-there being no roads through the woods, and the shores being so beset with cedars, stumps, and drift that we could hardly get along there with our sleds - we were startled by a crack which sounded louder than a rifle-shot near us, and looking back, we saw just behind an open space in the ice, eight or ten feet wide, where we had just passed, extending from the shore across the lake to the other side, a mile and a half distant. Later on we heard another report ahead, and when we proceeded two or three miles farther, we found a second opening across the lake, which, of course, we had to go around. The day had come out warm and sunny and caused the contraction.

In cold weather the ice expands, and on a very cold night when it is thick on the lake, you are regaled in the still hours by the constant rumbling and cracking and at times with sounds approaching the explosion of 
cannon in the distance, and large ridges of ice will be thrown up under pressure across the whole lake, across which you will have to cut away a passage to get a team through, and large masses of ice will be thrown on the surrounding level as if out-thrown by powder below.

The pressure of expanding ice is immense, equal to several thousand pounds to the square inch, and if you fill with water an iron ball with a shell two inches thick and plug it up and expose it to extreme cold, it will easily crack open. Therefore the pressure of thick ice in a lake will at times expand with such force as to throw out the shore ice on land in the twinkling of the eye, making a wall difficult to get over. I once saw while on the lake a shore ice wall commence a mile above me, where it got a start, and go two miles below in a few seconds, with a roar beyond that of half a dozen railroad trains.

When the lake was artificially raised some years ago, for impounding more water for the Androscoggin River and the mills below at Lewiston, an island not very far from my camp, of an area of a few acres, was flooded and frozen over in the following winter. This island had quite a growth of pine and cedars on it. One of my men was near when a strong movement of the ice occurred, and saw the crushing and toppling of the timbers as they were carried along by the moving ice all out of place, as shown the following spring.

THERE are great extremes of cold at the lakes from their altitude of $I_{500}$ feet above the sea, and the winter snows fall more heavily there than perhaps at any other locality in the country. The ice commences 
making in November, and by December roth is generally strong enough to bear teams over it, and accumulates in thickness until February, and does not go out for spring fishing on an average before May roth.

It is interesting to observe the freezing of the great lake, commencing in November. The deciduous trees have cast their last leaves, which to the end have semblance of October's gaudy tints, and evergreens have grown darker, and the shades of the valley ranges have a cold and steely look, and the mountains are deeper in blue.

The late autumnal days have surely come, and little flurries of snow and with them chickadees are in evidence. The ground freezes at night, and heavy frosts glitter in the morning sun. The last few flowers, and even the everlasting flower, which survived October's cold, fall supinely in dark coloring. The blue heron and kingfisher-deadly destroyers of small fry-have winged away, and the great American diver, or the loon, which breeds at the lake, has taken flight. The ducks and geese fly over hurriedly with southern trend. The robins, darling birds, are summer joys, who have bred in the bordering trees and proudly brought out their young broods upon the lawn, and taught them how to catch the angleworm, seeking the cool and moisture of the early morning. They, too, have thinned out, though some stay all winter. The deer have left the uplands for the cedar swamps. The frogs have ceased their croaking and night calls, and are floating languidly about on the lake's surface, preparatory to their dive for dormant winter quarters in the bottom mud. The trout, big fellows with mates, five and six pounders, are crowding on the spawning beds in their very height 
of coloring, in their best suits, with mottled backs and carmine spangles, tender in their love, and fierce in defending. How beautiful their blending of yellow, scarlet, and orange. How tame and seeming fond of attention. How many hours and days and weeks I have watched them, and for almost half a hundred years have I been among them, and some of them seem like old friends, and I meet them after a year's absence, for I have known some of them for years, large fellows, and recognize them readily in the same place year after year; and one I had so tame-partially confined with others-that feeding from my hands was frequent, and I have taken this one out of the water momentarily with my hands, more than once. But I must not go on with trout, or I will never end.

I will give you later on, perhaps, more of trout than you will care to read, and I leave the subject reluctantly to go on with the ice. The ice first commences to freeze in the nooks and little bays in its delicate interlacing threads of crystallizations, where perhaps it holds, protected from the waves, and gradually reaches out into the open, where it is to be broken up many times. The lake, though cold enough to freeze, does not, owing to the water motion. It grows steadily colder, and the water, dashing up on the fringing shore, varnishes the rocks and shrubbery with its crystallizations.

In a still night the ice wreathes over a large space, to be again disrupted, and again and again, while in the protected coves, it solidifies more and more, giving some skating. Then, after a cold, still night, the morning exhibits a frozen surface, but this is not a final closing, for a good blow breaks it all up again, by 
starting an opening, from which it rips up the whole length of the lake with surprising rapidity. But old Winter is stubborn and keeps on with his inevitable grasp, and stilling the wind upon a colder night, skims over the lake with half an inch or more of crystallization, and keeping still the wind the following day, adds half an inch or more. Not even then is the victory gained, for Boreas, now rampant, sends down a blast from the north, breaking up the ice for a mile or more, and leaping over for another mile breaks in below and tears open a mile or two, and so on for ten miles, skipping alternate miles perhaps.

Then cold weather, continuing, thickens up the frozen spaces, strong enough to bear teams, while the open places are still kept unfrozen by the envious gales, until caught by a still night, when the open spaces are cased over and one continuous mantle of ice reaches from one lake end to the other. Then the lake is closed until the first part of May following, and upon the ice falls the winter accumulations of snow, and as this weight depresses the ice surface, the water arises over the latter, permeating the snow and creating a top of snow ice which may be several feet in thickness.

Despite this accumulation, more or less soft places occur over springs in places where the water is not very deep, which cut away the ice, requiring caution in passing over, though the danger from going in is not great, as the surrounding ice is strong enough to bear one's weight in getting out. Horses are worked out in the manner I have before described, and many times I have gone in and aided in extracting horses without loss.

It was at one of the periods I have referred to when the lake was ribbed with alternate strips of ice from a 
mile to a mile and a half in width, with equal open places, in the month of November, over a distance of eleven miles from the foot of the lake where the logging road ended to my camp, that I made a notable excursion for deer stalking with Governor William E. Russell and a party of friends to the lake. The election in Massachusetts had just occurred, being the last election of Governor Russell in the State, and at our time of leaving Boston it had not been clearly shown from the returns whether Russell had been elected or not, to which he was somewhat indifferent, for he was fatigued and tired from many election speeches in the Commonwealth, having made from ten to twenty addresses each day for two or three weeks. But the subject was hardly one for discussion during our excursion, and our start-off was a rather sudden one. We had talked about going, but I had little idea of our taking the trip, and was in New York for a few days, preparatory to my departure for California for the winter, when I received a long telegram from the Governor reciting his fatigue from the election work, asking if I would take him to camp for a rest with three or four mutual friends, and if I could not go immediately.

It required but a few moments' deliberation for me to make up my mind affirmatively, though I had returned from the lake but a few days before, where I had been for several months, closing my camp for the season, leaving in charge my usual keeper for the winter, in care of my dogs, and to cut wood and ice for the following year, not expecting to return until the following May for the spring fishing. The ice had commenced to form in places, when I passed down the lake, and I had to break my way through it some 
distance to reach the shore at the logging road of exit. But I answered Yes, and would join the Governor for departure from Boston in two days after.

I put the telegraph in requisition, sending a message to the nearest town from camp, twenty-odd miles away, to send a special messenger to my camp keeper to have four or five boats at the end of the lake on the fourth day from date, with skates, wraps, etc. Another to my cook in Boston, a German woman ready for any emergency, whom I had employed for several years, and carried back and forth from camp to California, and who well knew my ways; one of stout heart and accustomed to adventure and rapid execution, to whom I had given a week's rest before her leaving for California. I telegraphed her to start the following day for the town nearest the lake, where she would be joined by my two guides who had been with me for a dozen years, and to get to camp as best they could, and have dinner ready at half-past six on the fourth day for half a dozen. The distance then was fortyfour miles from the railroad, two thirds by road and one third by water. I then telegraphed for sundry stores wanting, to be sent to the lake.

All went well. We left Boston on the set day, going to Portland, where we remained over night, taking an early train the following morning, and, after going seventy-five miles, arrived at the railroad end at I I o'clock. We had then forty-four miles to make before dark, and the days were short.

As we left the cars, a large stage sleigh with four spirited horses, previously ordered, was waiting. The sleighing was superb over a well-broken road, and we made the run of twenty-two miles to Andover in two hours and a half, changing horses midway. At the last 
town we had lunch prepared for us, and with three twohorse pungs took the last road through the woods to the lake, twelve miles, which we did in record time. From the last town we had at our backs a powerful southerly gale, and when we arrived at the lake it was blowing great guns. Here were our two guides and camp keeper and two boats, with the lake end frozen over solid as far as we could well see-not far, owing to the curvation of the land,-and we were told that the ice stopped a mile and"a half distant, and then came open water for a mile, and then ice, and so on alternately to camp, ten miles distant. It was great fun, and a remarkable trip we made with the gale driving us on; we could hardly stand against the wind.

The Governor and I put on skates and went off flying, for there was no snow to obstruct. Our guides had thoughtfully brought down four sleds to put the boats on to haul them on the ice, and as they saw the gale was strong enough to carry the boats along on the sleds, had blocked up the boats on them and provided themselves with short, stout poles, with heavy, sticking-out nails in the ends to steer by. Very ingenious are these Maine guides. After loading up, they let go with the wind, somewhat irregularly at first, but in fine form after a while, and the boats sledded over the ice about as fast as the Governor and I could go on skates. The great bother was to stop before the open water, but it was managed. Then we all loaded into the boats and pulled across the open, to take the ice again, and so on, shifting half a dozen times, and arriving at camp somewhat in the dark. The camp was lit up as a beacon of glorious expectation, and glad we were 
to arrive in such good season, where Providence seemed to have been so entirely with us.

With blazing birchwood fires, and dinner soon following, we were jubilant with hopes of the morrow and following days.

The lake was open north ahead of us, and at a good hour in the morning we were pulling our boats over it four miles to the head, where we landed, and followed a trail for a mile to a pond of a mile and a half in length, an adjunctive log camp I had there in the woods by the shore. Here we remained over night, still farther advanced in the wilderness of trees, our aim for the moment being to get away as far as possible from the busy haunts of men. After lunch we sallied out in various directions, trusting to fall in with some straggling members of the Cervus family, and did, but failed to score, and found a comfortable night's rest in our sheltered home.

The gale had subsided, and the night was tolerably cold, at zero, still, and the morning clear. We were off after a light breakfast before the sun smiled upon us, and before ten o'clock had a fat doe to our credit. After lunch we returned to the lake for home camp.

We speedily saw, as we expected, that passage over the lake was impossible for walking or boating, as it was entirely frozen over, and of too delicate cast for bearing, and too solid for breaking passage for our boats. So we hauled the boats higher on the shore, with bottoms up and oars beneath, and deserted them with affectionate regards. The fun was deepening with ripples of crimson and gold, and although our tramp through the pathless woods was up and down hill, and across some tangled swamps and windfalls, and to the 
extent of five miles or more in our detours, it was full of interest and gayety, with occasional rests at fallen logs for chat and solace of pipe.

What fun the early explorers had despite their privations and toils, in rest and liberty-Clark and Lewis, in 1804 , the first to cross from the Atlantic to the Pacific; Captain Bonneville, in 1835; Parkman and Pike, and the romantic adventurers' account of the Astoria expedition. Nothing for man is more refreshing and strengthening than to get away from the exciting and strenuous life of business and professional work, than change to the restoring virtues of rest and contemplation to be found among the waters and forests which remain in a primitive condition.

Governor Russell told me that never in his life had he felt more fatigued and worn than when he commenced this excursion, and never more refreshed and buoyant for labor than upon his return.

I put up a joke on the Governor on this trip which was rather amusing. When we arrived on board the cars, in leaving Boston, he was the recipient of many congratulations from accompanying passengers upon the supposed results of the election, and when we arrived at Portland he was greeted by a committee of welcome, which he vainly sought to avoid, and at several towns en route we found delegations of welcome in waiting, and it was thought necessary at our last town-where we took pungs for the last run through the woods to the lake-for a delegation of rustic residents, who had become advised of the visit, to appear and give a final send-off. The Governor, as we sped away from the settlement, said:

"Thank heavens, this welcome business is now over, 
and we will settle down to ourselves and our mutton." But not so, as appeared.

After a few days at camp, I made a trip with the Governor and one of the guides across the woods to another lake, where deer were promising in number, and we proceeded up a trail from the lake for a mile or so to an old deserted logging camp that I knew of. I had prepared in advance an old cot sheet with the words, "Welcome, Governor Russell," prominently displayed upon it with a marking brush, and this I had the guide pack away in his knapsack, instructing him how to act with it. Before we reached the camp over the virgin untrodden snow, at a babbling brook which crossed the road I signalled the guide to take a turn off to the right and see if he found any fresh tracks, while the Governor and I would rest and have a pipe at the brook. The guide started off and proceeded around to the rear of the old camp, which he entered through the old window-place, and tacked over the front door, without disturbing the snow in front, the sheet of welcome, and returning the same way as in entering, joined us at our resting-place, with the report that he had not found any fresh tracks; and we proceeded on, putting the Governor in the lead that he might get the first crack at a deer. When the Governor, well in the lead, saw the old camp in the way with its blazing inscription, he stopped and beckoned me up to him, and pointing at the conspicuous welcome, said:

"Why, what 's that?"

Rubbing and straining my eyes to the reading, I said:

"Why, it says, 'Welcome, Governor Russell'; don't you see what it is?" 
"Yes," said Russell, "but how came it here?"

"Why," said I, after some thought, "it must have been put up by the Mollychunkamunks, the settlers from the upper Megalloway."

"But there are no tracks," said the Governor; "no one has been here for some days."

The guide and I had to break out then, in which the Governor heartily joined, though much mystified until he, pulling open the door, saw the drifted snow inside disturbed and the snowshoe tracks from the rear window. We had it pretty hard on Russell that night when he returned and he related his experience amid the hilarity of our companions, and it was some time before he heard the last of "Welcome, Governor Russell."

Poor Russell, he died suddenly a few years after at a salmon-fishing stream in Canada. He was of modest and sportsmanlike quality, never happier than when away on the stream or lake or in forest expanse, entertaining, companionable, and appreciative, fair and honorable in all, and of most winning countenance. Strenuous without exertion, he made rapid headway in the esteem and affection of all who knew him, and I have thought if he could have lived until now, he could have been unanimously selected by the Democratic leaders for their chief, as one who though not possessing the massive brain of a Webster, or the magnetic power of a Choate, so combined the adroit faculties of mind and speech as to please all men, and whose honorable and skilful administration of State affairs as the Democratic Governor for years over the Republican Commonwealth of Massachusetts indicated the possession of abilities sufficient to have administered the multifarious 
duties of a national executive had he been called to that high and thankless position. He died young, and will ever be remembered by those who knew him well. I have from him a silver tankard inscribed by him, an unnecessary souvenir of his memory.

FROM I853 to I860, residing in Boston, I made several trips out to California, by either the Panama route or the Nicaragua, which were the most rapid methods then in vogue, requiring from twenty-five to twentyeight days. The wooden side-wheel steamers then in use were not to be compared with the present steelclad propellers; there were many mishaps occurring, and, if I am not mistaken, the prominent steamship line engaged in the California transportation lost from fifteen to twenty steamers in the business before the building of the great continental railway. On one trip we were struck by lightning in the Caribbean Sea, losing our mizzenmast and springing a bad leak, getting into Panama in a somewhat demoralized condition. Another time we broke our main shaft and had to roll about in a high sea, until we were picked up by another steamer and towed into port. Another time, with our steamer loaded to its full capacity with some fourteen hundred passengers, we struck a bad leak, in the Pacific Ocean, which gained steadily beyond the capacity of the pumps to relieve, and barely reached San Francisco in time to save the steamer from sinking.

One time I went out on old Commodore Vanderbilt's opposition line to Greytown, where we had to go up the Rio del Norte on small steamers to Lake Nicaragua, and, crossing that, take donkeys over the 
land to the Pacific. This was one of the early trips on his route, and we suffered great inconveniences. The river was low and the little steamers got aground frequently, when we had to tumble out on shore, to ease the boats off. At the lake we had to remain several days, for notice of the arrival of the Pacific steamer to take us on to San Francisco. There was a delay about this, and as the accommodations at the Pacific Coast, fourteen miles from the lake, were limited, the twelve hundred passengers were held at the lake, and the provisions there were not calculated sufficient for more than a day or two, and the native cooks were a bad lot, and the region was scoured about for chickens, pigs, and beef, with an insufficient supply, and if it had not been for bananas, we would have suffered much more than we did. The soups and meats had body enough on the start, but the soups gradually thinned down so that it became a mystery how they held out. I solved it to my mind and abstention, by passing the cooking department, where I saw all the soup plates emptied of the refuse bones into the kettles, to which were added hot water and seasoning, and the mixtures were served over ad infinitum at a dollar a plate. It was a regular treadmill business, and susceptible of much extension. It was undoubtedly good banting food, but satisfied me to be content with the nutritive qualities of the banana.

In Boston at this period I was very fond of sailing in the harbor, and when I found that a good breeze was blowing I would go down to Long Wharf and hire a moderate-sized sailboat, of sloop rig, and put out beyond the shipping in the open, and if the breeze was of good strength, it was a great pleasure if it freshened 


\section{A Sportsman}

up so I could run my boat on its side with a baling-out bucket to throw out the surplus water I took in. Occasionally I would come near being blown out to sea from the harbor mouth, and on one occasion had to wreck my boat as night approached on the last point of land to save going down, as the chopping sea water-logged my boat, which with its several thousand pounds of pigiron ballast would have soon gone under. Going down one day to the wharf I saw an auction sale going on of a fine trim sloop yacht of between thirty and forty tons capacity. Few were present and no bids came in, and at a venture I bid three hundred dollars, little expecting to buy so fine a yacht at that price, but as it was a peremptory sale, and no other bids came in, I became the owner, and upon looking it over thought I had reason to be well satisfied, as it was not far from new, and was completely equipped with sail and jib, anchor and ropes, and a good cooking stove forward, and a fairly good cabin with four bunks, and dining-table with adjunctive furnishings. It was the Charlotte Cushman, and had a set of colors given by that distinguished artiste. It seemed quite unlike a white elephant, and I communicated an account of my purchase to my two friends, Poor and Lane, clerks in the wholesale establishment of James Read \& Co., and invited them to join me in the venture, which they did. As they were not overburdened with funds, nor I inclined to the possible lavish expenditure which might be entailed by the luxury of a yacht, it was agreed that we should pursue an economical course, as follows: To hire a good skipper and allow him let our boat for pleasure and fishing parties, using it when convenient for our own pleasure. This we did, getting 
a very good sort of a fellow for skipper, giving him moderate pay, and allowing him to participate in a portion of the rentals. We ran the boat for three years, when we sold it for about four times what we paid for it, and although we added several hundred dollars in additions and repairs, we had the advantage of the letting, and came out well paid in profits, besides the pleasure and recreation we had. My friend Poor, who was very fond of yachting, came very near losing his life on a yachting excursion a few years afterwards when sailing in Long Island Sound. He was reading in the yacht cabin when a violent squall came on, which nearly capsized the boat. As he rushed out of the cabin the boat inclined over on its side from the squall; he pitched headlong into the sea, while the yacht passed on at a rapid rate, his mishap being scarcely noticed in the confusion aboard, and was soon left behind. He could not swim a stroke, but retained his presence of mind enough to keep paddling with his hands by which he kept his body afloat, and was finally rescued, having been seen by the captain of a Sound steamer, who had observed, though from a distance, the striking of the yacht by the squall and thought he observed some one go overboard, and using his spy-glass saw Poor in the water. He diverted his steamer from its course, and as he came near, sent out a boat and picked him up. He was then about insensible, but still keeping up his hand paddling. From this he afterwards entirely recovered, and died but recently while President of the Park National Bank of New York, the second largest capitalized bank in that city.

With my friends, Ned Poor and Lane, we organized 
during the yachting period a literary society, which we called the Webster Debating Club, limited in membership to fifty, of which I was President, Poor, Vice-President, and Lane, Secretary. After four years of the club's existence, our attention being elsewhere attracted, the club was merged in with another association of like character. We had a good deal of interest and comfort in this club, of which we had weekly meetings, and conducted a literary magazine, from which the offerings of our members were read, and we discussed the important questions of the day with much freedom, if not ability. We started in quite a humble way, but having the indomitable assurance of Lane to head committees of solicitation, we grew comparatively opulent, and soon had a permanent hall engaged and furnished.

I look back with amusement now with the remembrance of Lane's boldness and undiminished energy in striking for donations, when rebuffs to him were but incentives for renewed exertions. We created a long list of honorary members-who never graced our meetings by their attendance-which included the President of the United States, Senators, and local celebrities, who were duly notified of the distinguished honor of our attention, and who almost always responded with appropriate letters of acceptance, and who became objects of attention without delay from our soliciting committee, and who often responded with Congressional documents and publications, which although not especially adapted for a library of reference, made an important array in our hall. I called with Poor and Lane on Charles Sumner, Edward Everett, and Governor Banks, and listened to the alluring invitations of 
Lane on the opportunity offered of having their works illustrated upon the shelves of the club. To this they all responded, but when it came to the straight asking of money donations I felt a diffidence I could not overcome, but Lane felt no false sentiment in this respect, and the twenty-five and fifty dollar donations he raked in became rather alarming when we had secured enough to defray all possible expenses for a twelvemonth ahead, and we had to call him off, in fear our abilities would not be sufficient to sustain the expectations which had been created.

With our hall furnished, we branched off with a course of lectures, dead-heading a semi-distinguished embryotic class of orators, merchants or others, who, having visited the Holy Land, had stood on the pyramid of Cheops, or had seen Vesuvius in eruption, and whose narratives had been of intense interest to admiring friends, but who had not yet been called upon by the acclamation of the public to stand in prominent places. To them we gave hearty welcome, and rewarded them with thanks and a dozen or two of tickets. Our tickets were twenty-five and fifty cents, depending upon the location of seats; if near, where the expressions of the lecturer could be clearly observed, and no words lost, fifty cents; if in the rear where words sometimes flatten out and possible draughts occur, twenty-five cents.

Numerous bunches of tickets would be disposed of, and often to prominent parties whose presence would add éclat to the occasion, but whose appearance generally failed, owing to remarkable coincidental absences. A survey of the audience would sometimes indicate that the lower classes were awakening to a realization 
of their wants, and that the cuisine and laundry departments were looking up.

We had some rather clever young members of our club, many of whom have gone before. Lane, despite his retiring disposition, still lives in the possession of a large fortune. We had in political ways some opposites: George H. Hoyt, was a most eloquent young speaker, of decided Anti-Slavery sentiments, who upon the trial of Ossawatomie Brown, who made the foray at Harper's Ferry, ending in his execution, went down and appeared in his defence as counsel, and who died soon after. J. B. Shepard, quite the opposite of Hoyt in political ways, became prominent in Tammany afterwards. Hiram B. Banks, brother of Governor Banks, fell at Fair Oaks in the war, as did several of our club members. Several are still living in Boston in mercantile life. Two or three went to the bad from drink, and others I have lost sight of. About this time I met Richard and Peter B. Olney, the former afterward Secretary of State under President Cleveland. I met them for the first time at the country residence of my friend their uncle, Peter Butler, at Quincy, Mass., during the Christmas holidays. They both were then completing their collegiate courses in Rhode Island, and were about my age. They were strong, hearty lads, and of the two I gave Peter B. the preference in looks and manners. On the first day I met Richard, he was spending the greater part of his time in scouring his somewhat prominent teeth with the bruised end of a stick of liquorice wood. He was not particularly attractive, and his countenance was disfigured by a large prominent scar across one cheek, which gave him a somewhat severe aspect, but his cast 
was strong, and soon after entering the law office of his father-in-law he made rapid progress, and later on became associate counsel for several important railroads, one of which, the Atlantic and Pacific, had a pretty hard time in its earlier days, being constructed through a very barren country from Albuquerque in $\mathrm{New}$ Mexico to Mojave in California, and a road with which I had some familiarity, and at the time of making its annual report, I was in some wonderment what kind of a report could be given satisfactory to the stockholders. When the report was made, I was surprised at its clearness and power, and, well aware of the tactfulness of Richard, I immediately assumed that, as I did not know of any officer of the company whom I thought capable of writing so clever a report, he had written it, and called upon him at his office and mentioned my conclusion, which, in a smiling way, he neither affirmed or denied. As a corporation lawyer I account him one of the first, possessing a superior knowledge of law, and a clear-headed, drastic method of expounding seldom equalled. As a chief executive of the nation I should have more fear of his combative and antagonizing spirit than I would that of which animated the lamented President McKinley and Governor William Russell. Knowing him as well as I do, he would be one of the last of whom I should ask a favor, and in saying this, I but echo the expression of a dear friend of mine, to whom Mr. Olney was indebted for many substantial advantages.

In I860 I engaged in a commercial business, which I followed for five years, but which grew more engrossing year by year, until I found myself so confined that I had a difficulty at times in arranging my visits to the 
lakes, although I laid out my sporting excursions for months ahead, which I never, despite many perplexities, failed to respond to.

This was the period when I denied myself the reading of books and papers pertaining to sports, as too inflammatory for my peace of mind, and if in looking over a paper I saw the heading of game killing or adventures, I passed it by, waiting as patiently as I could for my times of excursions.

While engaged in business, at the commencement of the Civil War, having belonged to a military company for several years, the Independent Corps of Cadets, I enlisted with several hundred men I had secured, on the first call, for three months' service, and received a captain's commission, serving for the period mentioned. It was thought at the time that the war would be of short duration, but unfortunately this expectation was not realized, and the war carried on for several years occasioned the loss of over a million men, and over three billions of treasure to the government, and probably several times the amount of three billions in the aggregated loss of expenditures by the Southern Confederacy, in the loss of slave ownership and the destruction of property. That the war was a necessity, except from the heat of the irrepressible conflict brought on by the Abolitionists of the North and the fire-eaters of the South, is not quite clear. The fanatical classes, North and South, fanning the flames of disunion, were at first viewed with amusement by the conservative sentiment of the country, but at last all became involved by the hasty acts of these fanatics and demagogues, creating a necessity for every one taking a warlike stand on one side or the other. The 
crisis came when argument and reason were unavailing. If the Abolition leaders and the fire-eaters, firing at each other at long range, could have been confined in some area, where they could have fought to the extermination of each other, it would have been a great blessing to the country, and the war could have been averted by the action of sober reason by making a proper valuation of the slaves to be paid for by the general government, thus removing the primal cause of conflict. This, however, could not have been brought about at the time of President Lincoln's election, for neither the North nor the South would have consented to it.

DISPOSING in the early part of $\mathrm{I}^{86} 5$ of my commercial interests, and experiencing the exhilaration of a freedom I had long been denied, I resolved to take my way to the Rocky Mountains, having read so many accounts of adventurous life there from the interesting sketches of the early pioneers.

Before leaving for the West I concluded to take a trip down to the Pennsylvania oil regions, which at that time were creating much excitement. This I fancied would be a rather agreeable excursion, but found in it more peril than the one I soon afterwards made across the great plains to the mountains. Before the train I was on reached Titusville two miles distant it came to a standstill from an excess of water over the track. It had been raining for several days, and the country was flooded. The train was in a sheet of water several hundred feet from land, and as the water was growing deeper-already so deep as to almost put out the engine's fire-it was deemed expedient to hold 
up, perhaps for all night. The train was loaded with passengers to excess, so much so that many had to stand between the occupied seats. It was not a pleasant situation. Some countrymen after awhile made a rough raft of fence timbers and boards and poled out to the train, offering to take passengers ashore for a dollar apiece. I secured a place on the raft with all the baggage I had, a pretty good-sized hand-bag. Too many availed themselves of the opportunity offered, and in consequence when about fifty feet from the land the raft broke apart, and let us all in the water. Fortunately it was not very deep, but pretty nearly up to one's shoulders, so we all waded to the land with our hand-bags thoroughly soaked. No teams of conveyance being at hand we all walked on to Titusville, conveying our bags after draining out what water we could.

It was dark when we arrived at our destination, and we found the water running through the streets up to the sidewalks and in some cases over. It being in the very height of the excitement, the little town was crowded with a great many more visitors than it could accommodate, and the only hotel there could hardly feed its guests, and no rooms or beds could be obtained. The sitting-room and halls were occupied for sleeping places, without cots or mattresses. There was a large barroom, crowded full, where the tobacco smoke was so thick that it could hardly be seen through. The exciting subject of conversation was Oil! Oil! Oil! Great strikes and the expression of hundreds of thousands of dollars were as plentiful as flies in the dog days, and one would suppose from the somewhat rough crowd present that it was composed of millionaires in 
disguise. There was a large cylinder stove in one part of the barroom, so red hot that more space existed about it than elsewhere, and near this I proceeded to the inner circle. Here I divested myself of my outer clothing, and managed in an hour or so by revolving about to pretty well dry my underwear. Wringing out the contents of my bag and holding out some of my outer clothing, I managed before I lay down on the floor for the night to approach some degree of dryness, and I passed the night much more comfortably than one would if lost overboard at sea.

At the railroad station in Boston, just before leaving, I was sought for and found by an acquaintance, Carlos Pierce, who had happened to hear that I was going to the oil regions, and who asked me if I would visit a tract on Oil Creek below Titusville, which he had an option of purchase on for a limited time for some amount. I told him it was quite impossible as I was going on a pleasure excursion and I could not give any attention to business. He was very persistent and disinclined to take a refusal, and finally said as his period of option was short, he would give me five hundred dollars to take a look at it, even brief, and inform him by telegraph if a new well of value had been reached upon the tract, which had been reported to him, but which he had some doubts about.

I finally yielded to my friend's solicitations, though reluctantly, and the result put me to a great deal of bother, for the next day was the one I should have to visit the tract and the prospects of getting there in the morning appeared very dubious when I looked out on the booming Oil Creek, and the frightfully muddy roads. Besides, the bridge across a creek close to the town, 
running into the main road, had been carried away, and this creek had to be crossed on the route down Oil Creek to the optioned tract. The creek, I was told, could be forded a short way above the bridge site. I managed, over the muddy and half-flooded sidewalks, to get to a livery stable to engage a saddle-horse for the trip, but was met with a decided refusal from the keeper to let any horse out in the present condition. Looking over his saddle-horses, I asked him if he would sell me a pretty sturdy-looking nag with a saddle and bridle outfit, which he answered in the affirmative, the price being one hundred and fifty dollars. I paid him the sum, and started out, leaving my bag with him for safekeeping until my return. My starting out to ford the creek attracted a number of dead-head spectators as the creek had not been forded since the loss of the bridge. My horse took the water in good courage, but the water kept growing deeper until I had to hold my legs up as high as I could, and I commenced to congratulate myself upon a comfortable passage, when my horse dumped in and commenced swimming. I had some difficulty in keeping on, but had acquired some experience in swimming horses, and succeeded in doing so by hugging down on my horse's neck and by holding on to his mane. I lost my seat before getting over, but kept my mane hold, and although the current was strong got safely across with him. I then had fifteen miles of a frightfully muddy road to get over to the tract in view, where the mud in its clayey, tenacious character was about the worst I ever encountered, and if I had not had a very strong horse I could never have gotten over it. I arrived at the tract about noon, and found in reality that a new powerful. 
oil-gusher had been struck, adding much to the value. I then had to detour several miles to Franklin for a telegraph office, and send off a message to Pierce.

Oi. City, on the Alleghany, at the mouth of Oil Creek, was fifteen miles below, and although a drizzly rain was falling-from which I hadbecome immune-I pushed on over the muddy roads. As I occasionally came in sight of Oil Creek, I saw that it was at a booming height, and carrying along trees and wrecks of buildings, with an occasional small house or two and dead cattle, with the water more or less surfaced with petroleum from overflowing wells or damaged tanks. At Oil City-as I approached at sundown-I saw the backwater from the Alleghany River had spread over a large area, flooding a large part of the town from which the inhabitants had fled to higher ground where they were camping out, as all the upper ground houses and the church and schoolhouse were filled up. It looked unfavorable for a night's lodging. But as I passed along I overtook a gentleman with whom I had some conversation, and who kindly offered to give me a sofa in his sitting-room, his house otherwise being crowded. This I gladly accepted, and got my horse well put-up and fed. The wife of my host gave me a good supper accompanied with a bowl of fine coffee, from which I partook so heartily that I failed to get any sleep during the night, nor did I feel particularly fatigued. Having a stove in the room I occupied, I dried my clothes pretty well and passed the night in reading from the small library my room contained.

The following morning I mounted my steed, which I found comfortably refreshed, and rode back to Titus- 
ville, succeeding in getting across the creek I crossed the morning before, by going up higher, and got over without swimming my horse. I was the first down to Oil City to carry news of the conditions above, and the first on my return to give news of the conditions below. I succeeded in getting a bed that night and obtained a good rest.

The water had fallen, though still high, and the town was still crowded as before. I concluded I had seen enough of the oil regions and would return home. The trains in and out from Titusville were running very irregularly, and I took the one out in the afternoon for the Junction, where a change was to be made to another train, to arrive in a short time, but the expected train did not arrive until two o'clock in the morning and was crowded to its utmost capacity, and could in no way accommodate the passengers waiting; but I succeeded in getting on and in checking my bag to New York, which was fortunate, or I would otherwise have lost it in the wreck which followed.

The morning opened bright and clear, and after breakfast at a stopping-place, I crowded into the front smoking-car to have a smoke, the car and train being as crowded as the train I came down in, with a large number of passengers standing in the passageways and between seats. The track was very rough, and water flew out occasionally from beneath the sleepers as the train passed on; still the train was pushed on with great speed, so much so that I became much alarmed, and one of the passengers remarked to the conductor as he came along that he thought the speed was altogether too rapid, with the condition of the road, to which the conductor replied rather curtly, with an 
intimation that it was his business. I felt so much alarmed with the rocking and swinging of the car that I thought it prudent to retire to the rear end of the train, which I had great difficulty in doing in pushing through the crowded cars, there being eleven of them from the baggage. The last car was a sleeper, crowded full, of which the door was locked to keep out the frequent calls of outside passengers for admittance. Finally, by thumping vigorously, I brought the porter to the door, who opened it partially, and in answer to my request to be admitted declared that it was utterly impossible, as it would hold no more. I told him it was important to see a friend of mine in the car without delay, at the same time exhibiting a fivedollar bill, which I offered him in case of admission. It was sufficient for my purpose, and the colored porter passed me in, finding the car as much overcrowded as the others.

Not more than five minutes after my entry, a violent series of shocks occurred, as of most severe breaking up, which came from the smashing of the cars ahead, and which brought our car to a standstill, but not until the front half had left the track, being the only car of which any part remained upon the rails. We were not prepared to witness the scene which met our sight upon going out from our car. No wreck could hardly be more complete. We had been running at a speed which I should estimate at fully forty miles an hour. A broken rail over which the engine and baggage car had passed threw off the smoking-car and all following to the sleeper. The car next ahead of ours was thrown over on its side with its front end smashed in. The next three or four cars were more or less 


\section{A Sportsman}

smashed in and lying in a deep ditch full of water near the track, bottom side up, with their wheels sticking up. One of them was so deep in the water that the water was above the windows. The other cars were lying smashed up at various angles. The injured passengers were giving out groans and piteous cries. All those who were uninjured gave immediate aid, and we stretched out on the track the dead and badly wounded. The upturned car so deep in the water could not be opened otherwise than by breaking in from the bottom, a most difficult and prolonged work which was effected by axes and the broken rail, and in this car a number were drowned.

This was the most terrible accident it was possible to imagine, and the only one in all my experience I ever witnessed where death occurred from a railroad wreck, and I believe I have travelled by rail during my life a distance equal to that of ten times around the world. In this accident over a hundred persons were killed or wounded. Over thirty were killed outright. It was a shocking sight to see the dead, dying, and wounded lying along the track. It was some time before an aiding train brought medical attendance and helping hands. The accident occurred the latter part of April near the small town of Oriskany. It was eleven miles to Utica, and it was so long before a train was ready to convey the remaining passengers that I walked the track to that town; there I caught a train for New York, where I afterward obtained my travelling bag. This was the ending of an intended pleasure trip.

I caught a bad cold, and when I arrived in New York I had a fever and broke out with some boils 
on my neck and face, which confined me to my room for between two and three weeks. Before I fairly recovered my usual good health I returned to Boston and, gathering in my fishing rods and guns, started for the distant West in the month of May, I865. No railroad was then built reaching to the Missouri River from Chicago, excepting the Hannibal and St. Joseph, which was then badly broken up and periodically raided by the holding-out rebels in the State of Missouri. I therefore took the Chicago and Northwestern Railroad from Chicago, which was not then extended nearer than seventy miles to the river, staging the balance of the way to Atchison, and from there by the Ben Holliday line of stages to Denver across the unsettled great plains. These stages left daily, consuming from six to seven days en route, travelling day and night over a region where then existed a condition of warfare with the numerous tribes of Indians, banded together in united hostilities against the whites. At this time some ten thousand soldiers were required to keep the route open. The troops employed were largely composed of Confederate soldiers taken prisoners during the war, and were designated as Galvanized Yankees, and were so employed in the scarcity of government soldiers, who were required at the front in the great struggle for the preservation of the Union.

It was necessary to have each stage across the plains accompanied by an escort of mounted soldiers, and even though so protected stages were often attacked and driven into the stations existing from fifteen to twenty miles apart over the way. All the male passengers by the stages carried guns for defence, and constituted in themselves a strong force. In case 
of attack it was the habit of passengers to take the rear of the stage, where a better resistance could be given than when cooped up inside. On this trip no attack was made, though we had some false alarms and fancied we saw Indians occasionally in the distance.

One morning at an early hour we saw a man a long distance off, running toward us and waving his arm in signal. A pocket-glass showed him to be a white man, evidently about stripped of clothing. We held up for him, and when he was able to gain his voice after reviving from his exhausted condition, we found him to be the sole survivor of an Indian raid. The Indians had captured a ranch house some miles off on a creek, where a family of eight, which included four men, had all been killed but himself. $\mathrm{He}$, being taken unwounded a prisoner, was probably reserved for torture. He had been almost stripped of his clothing, and had a finger chopped off, to secure a plain gold ring he wore, which was difficult to remove. He could, he said, have worked it off in a little while, but the impatient savages upon discovering it had a competition for its possession, and it was settled abruptly by one of their number cleverer than the rest, who lopped off the offending member, and from ignorance of anatomical operations very nearly severed two others. The prisoner had been tied up for two nights, held in reserve for an hour of recreation, when the gentle savages would have the leisure to fully enjoy the pleasure of his sufferings at the stake, which he had reasons from significant signs to believe would occur on the following day. He had the night preceding his reaching us managed to get loose from his thongs and steal off. He travelled about in the dark, getting some miles 
away from the Indian camp, and at daylight, seeing no traces of his enemies, made haste in the direction of the Overland road, knowing from the rising sun the general direction toward it, resulting in his secured escape. His naked feet were bleeding from the prickly pear plants he had travelled over, and altogether he was a sorry-looking object. We left him at the next station.

Although somewhat weak in the first days out in staging I pulled up pretty well before the arrival at Denver, after the six hundred miles of passage. Denver was then a somewhat dilapidated town of a few thousand people, and as we drew in at the Planters Hotel-a rather unpromising wooden building-we had a delegation of citizens there to inspect the new arrivals, as one of the prominent events of the day. It was at Denver, in the small stream running through the town, that gold was first discovered a few years before, and which led on to the finding of the mineral veins in the mountains above. The population of the Territory at the time was estimated at from twentyfive to thirty thousand, of which a large proportion was scattered about in the mining districts.

Our arrival was heralded in the following morning paper, and I was amused at finding myself designated as a prominent professor of mineralogy sent out from the East by important financial interests to invest in the unrivalled mineral wealth of the region. This beset me with numerous calls during the few days I remained in town from embryotic millionaires, who carefully unfolded packages of mineral ores for my inspection, with intimations that I could glut myself with boundless deposits of golden ores in the mountains 
without even going up there for examinations. To the first caller I gave assurances that my knowledge of mineral ores was exceedingly limited and that I was not even a professor. I overheard my querist afterward reciting to a small audience that I was a humbug and did n't even know a good ore when I saw it. This led me to exercise more caution, and securing a small magnifying-glass and a pocket mineral-scraping knife, I was better prepared for the next visitor, who unfolded a precious specimen from the celebrated Killbug mine. I put on the full power of my glass in critical examination, remarking:

"How much have you got of this?" to which he might rejoin, "Seven hundred feet and Brother Tom has four hundred feet more."

Then giving the specimen a scrape with my mineral knife and another glass examination, I would say, "Better hold on to it," which I felt quite sure he would. I then began to retrieve my sinking reputation.

In a few days I took stage for the Central City mining district, forty miles up in the mountains, situated on a creek between hills. Colorado was then in a very languishing condition. The decomposed surfaceground over mineral veins having more or less free gold had been worked over, as well as favorable gulches; and the stubborn sulphurets, though gaudy and attractive to sight and containing more or less gold, could not be successfully worked, owing to the association with sulphur, zinc, iron, and various other minerals.

THE discovery by some emigrants, in 1858 , of gold upon the shore of Cherry Creek, in the present 
city of Denver, twelve miles from the mountains, first drew attention toward Colorado as a mining region. At that time there were no white residents in the Territory, excepting a colony of Mexicans, who were located in San Luis Park, in the extreme southern part, engaged in sheep raising, cultivating the soil to a limited extent, and depending upon the trading settlement of Santa Fé South for their supplies. With this exception the whole region was wild and unbroken, inhabited in sections by tribes of Indians living in a primitive state, who, drawing from the soil a very scanty proportion of the food required by them, depended almost entirely upon the wild animals abounding in the region. These tribes were constantly in strife with each other and by their hostile manners prevented peaceful settlements in the region, claiming it as their hereditary hunting-ground.

The discovery of gold, however, stimulated an emigration of hardy pioneers from the eastern section of Kansas, Nebraska, and Missouri, who, going in bodies, were sufficiently strong to defend themselves from any attacks which the Indians could make. These emigrants followed up the different tributaries of the Platte into the mountains, where they discovered a large number of rich mineral veins.

During the years of $1860,186 r$, and 1862 there was a continuous stream of emigration to Colorado, but during the years of 1863,1864 , and I865 it received a material check; this owing to a variety of causes, some of which we will briefly review. First, the war unhappily existing in the United States distracted public attention to a great extent from the region; also reports-having their foundation in reality-of the 
privations and sufferings experienced by the first settlers were widely circulated through the United States. The long passage, exceeding six hundred miles, from the last settlements of the Eastern States to the mountains of Colorado, over a sweeping plain, denuded of timber and yielding only a precarious supply of food to man, necessitated the taking of supplies sufficient for the through passage. This passage, when taken with mules or oxen, required from thirty to sixty days, and was often indefinitely prolonged by bad weather or by the loss of animals. In such cases-which were not infrequent-and in others when the amount of provisions taken was inadequate for the ordinary passage, much want existed, and for a period extending a considerable length over the early days of Colorado there was a great scarcity of food in the mining regions, and often the worn-out emigrant from the plains arrived to find a condition of affairs but little better than he had known upon the road.

There were also great difficulties met with in working the refractory minerals found when the mines were sunk below the surface ores; these, though vastly richer than the decomposed ore above them, would not yield the precious metal by the simple and rude process found so profitable when applied to disintegrated or alluvial deposits.

But the great evils which discouraged emigration more than any others were those entailed by the Indian wars, which raged during the years 1864 and 1865. The different tribes of Indians upon the plains, who saw the regions they had so long considered exclusively their own continually invaded by emigrants, were not slow to resent a real or fancied injury, and 
sunk their personal animosities, their heritage, and combined in a general league against the invaders. The opportunity was seized when the Civil War in the United States had reached its greatest height, when the government, requiring all its power, had withdrawn to a great extent its forces from the frontier. The injuries, aggravated by acts of retaliation given and received, inflamed the Indians to more desperate acts of valor and cruelty than they had ever exhibited before.

With scarcely an intimation of their purposes, they suddenly and simultaneously attacked the route over the plains. Sweeping down upon emigrant teams, and the small settlements which had been established every twelve or fifteen miles upon the route, as stations for the mail and stage lines, they massacred the whites indiscriminately - men, women, and children,-often scalping and mutilating the bodies of their victims. The wagons and buildings, after being divested of all that pleased the savage eye, were given to the flames. In one place, for a distance of one hundred and fifty miles, the route was made desolate. From other places the inhabitants and emigrants were driven to central spots, where for days they were besieged by their savage foes. The military station at Julesburg, where a considerable number of troops were congregated, as well as emigrants, was surrounded for a number of days by a large body of Indians who, cutting off communication in every direction, made desperate efforts to obtain possession of it, and were only repulsed by the use of canister and grape.

The number of Indians engaged in these outrages was from ten thousand to fifteen thousand, though at 
the time the number was supposed to be larger, as the tribes to which these Indians belonged comprised some thirty thousand warriors. The condition of affairs in Colorado during these difficulties was aggravated by the expectation of attacks from other tribes than those engaged upon the plains, who were living in the mountain regions adjacent; but, fortunately, those tribes maintained a peaceful attitude.

In the meantime troops were sent from the East, and volunteer companies were organized in Colorado from the hardy miners, who scoured the plains in all directions and soon opened the route. But the vigilance and activity of the savages prevented their being punished to any considerable extent. In one instance, however, a large body of them were surrounded when encamped near a stream, not a long distance from Denver City, when from four hundred to five hundred of the Indians were killed.

During this condition of affairs, although the mail and stage lines were open almost all the time, and passages of combined bodies of emigrants were regularly and safely made, prices for the necessaries of life rose to a height previously unknown in the Territory. Corn, oats, and other grains sold at from twenty to twenty-five cents per pound; potatoes from five to fifteen cents per pound; flour, butter, and other articles of food sold at prices correspondingly high. Freight across the plains to the Territory readily commanded an average price of ten cents per pound, in some instances reaching twenty-five cents per pound.

The natural result in Colorado was an increase in price of labor, which could not be obtained at less than from $\$_{5}$ to $\$$ ro per day. During those years mining 
languished, and at least half of the miners who had emigrated to the Territory in previous years left it for the new mining regions still farther west, which had their communications with the States of California and Oregon, upon the Pacific Coast.

But despite the high prices and Indian difficulties which prevailed, a large emigration set in during the summer of the year I865, which was encouraged by the protection afforded by the government in placing ten thousand troops upon the route from the Missouri River to Salt Lake.

A large number of the emigrants who crossed the plains in 1865 were en route for regions beyond; but the amount of freight received in Colorado during that year exceeded that of any previous one; and a large number of settlers were added to the population of the Territory. The emigration over the plains during the year 1865 was immense. The government alone paid a sum exceeding $\$ 6,000,000$ for freight across the country to its various Western military stations. The amount of freight which was carried over the plains in I865 is estimated to have exceeded one hundred and fifty million pounds.

From fifteen to twenty thousand teams were employed in the passage, some of which made two trips to the mountains during the summer, the average amount of freight carried by the teams being five thousand pounds, each team having four to six horses or mules, or from six to twelve oxen. The writer, while returning east over the plains by stage in 1865 counted in three days 3384 teams of this description, all passing westward; the distance made by the stage during this time being three hundred and twenty miles. At one 
point upon the route there passed westward, by actual count, in sixty days, 9494 teams, having over fiftyeight thousand head of horses, mules, and oxen.

The emigration of 1866 was large and steady, uninterrupted by Indian raids, the savages having been driven far away from the routes. The plains, though free of timber, are well watered, and covered with a rich soil, which yields a heavy-bladed grass of the most nutritious quality, and from which the cattle employed in freighting to Colorado acquired a fatness which well fitted them for the market. This grass grows in a native state to a considerable height, and could be cut for hay by thousands and millions of tons.

Antelopes in large numbers were found upon the plains, also rabbits of large size, wolves, ground-squirrels, grouse, snipe, curlews, etc. Immense herds of buffalo roamed annually over the expanse, at times so plentiful as to prevent for days the passage of teams. At some seasons they could be seen by thousands and tens of thousands, strung out over an area of from fifty to one hundred miles in width. The Indians slaughtered them in large numbers; and, after taking from them favorite strips of meat, left their immense bodies, weighing from six hundred to one thousand pounds, to be eaten by wolves or to decay upon the ground.

The Civil War, and especially the Indian hostilities in the plains, had largely distracted attention from the Rocky Mountain region, and as no process for working the refractory ores was known-among a class principally composed of ruralists-money had become very scarce; in fact, the Territory was very hard up in a financial way, and a good honest American dollar 
(worth to make about forty cents) was as large, metaphorically saying, as a cart-wheel. Everybody had mines to sell, and no buyers, and expectant millionaires were hard up for tobacco and stimulants. I hired one afterwards to ride a mule with a load of provisions and cooking utensils to go into the parks on a hunting excursion, who modestly computed the value of his holdings at twenty millions of dollars, and who had put up his ten-dollar silver watch for a small loan to tide himself over, as he told me.

The occupants of the numerous caravans of 1863 and 1864 , which had struggled across the plains so manfully for the auriferous deposits of the Rocky Mountains, with the suggestive mottoes on the sides of their ships of the plains of "Pike's Peak or Bust," had found that the accomplishment of the initial object comprised the full sense of the alternative.

Denver fell down nearly half in its population in I 866 by the exodus out, as soon as the plains were practically cleared of the Indians. The different tribes of the desert were largely overcome in I866 and I867 and placed under guard on reservations, and it was found much cheaper to feed and blanket them than to fight them.

I fished about the streams of Boulder and Clear creeks with indifferent success, owing largely to the cloudy condition of the waters from mining works. At Central City I met H. M. Teller-now United States Senator from Colorado-who has been a long time in political life. He was the leading attorney in the State, and I trust he will take no offence if I mention that I retained him, in view of possible want of advice, for the sum of thirty dollars for the year. At the Gold 


\section{A Sportsman}

Dirt mining district I met George M. Pullman, afterward prominent in railroad affairs and President of the company bearing his name.

I made an excursion with a guide and hunter named Utter for mountain goats in the ranges higher up than at Central, the altitude of the latter being about eight thousand feet, and where goats had been seen, but without our seeing any, although Utter killed a large grizzly bear, of which I still have the skin in Maine. Utter tracked the bear over a thin fall of snow to its den, and left our camp, which was near, at the very earliest gleam of light and took his place in a tree opposite the den and fatally shot the bear as it came out, in less than an hour after Utter had taken his position.

Colorado at that time was as rough in its social elements as new mining regions generally are, and had a stronger color put on in this respect by the influx of a highly dangerous class from Missouri and Kansas, composed of men who belonged to the bushwhacking and guerilla bands which had been broken up finally by the close of the war, and those who were not killed or captured had to flee for their lives and many came out to Colorado, where they were more or less looked after, and a good many were shot or strung up on short notice upon their capture, after committing robberies and murders. It is surprising to note that these desperadoes could act as badly and reckless as they did in view of the disgust they created and the steady decimation of their numbers which occurred from the indignant communities they infested. But they kept coming, and some, separating from others, distributed themselves in the various mining districts, where they 
were soon spotted and disposed of unless very careful in the various disguises they adopted. Others ganged together and occupied separate camps from the miners, from which they would make forays as of old in the regions they formerly raided.

These desperadoes were generally known as the double-pistol brigade, from their accoutrements and from wearing two large six-shooters in their belts. Four of them made a raid one night when $I$ was at Central in an office building belonging to the Bobtail Mining Company in town, which kept its bullion accumulated in the office safe before shipment, which building was not occupied at night, but was near other occupied buildings. These whackers had tampered with one of the miners employed by the company through whom they learned of the safe deposits, and whom they had gained over, they supposed, but who weakened and divulged to the owners all about it, and the night and hour when the raid was to take place. The whackers came, and as they opened the office building they were fired upon by concealed guards, and so effectually that all fell, three killed and the fourth mortally wounded. Here the bodies were allowed to lie on the ground, and $I$, hearing of it, went down in the morning to see the sight. The bodies were still there in view of the assembled spectators, with the wounded man still alive, cursing everything and everybody and without medical aid, and soon died. It was proposed to string him up in his dying condition, but better counsel prevailed.

I HAD two friends at Spanish Bar, on the Platte 1 River,- - about five miles from Central,-Brune and 
Davis, who were both disciples of the pleasant sport. I was in the habit of visiting and fishing with them and went down one day to pass the night with them, Brune being a surveyor and Davis the local Recorder of the mining district. They had a little house there in which they lived, and there were no more than three or four houses then in the settlement. It was a pleasant afternoon and I walked there.

Spanish Bar was situated at a much lower altitude than Central, and leading down to the Bar was a long, steep ravine, called Virginia Cañon, which had a wagon road down it. Three quarters of the way down was a deserted log cabin and a turn in the ravine. I met no one until I reached the cabin, and here I met a very rough man, hatless, whose countenance indicated the free use of ardent spirits and whose eyes were red from recent libations. He wore a thin linen coat, and as the breeze down the ravine blew it open I saw that he was doubly armed with a brace of big six-shooters. I had met one of the double-pistol brigade, and it was not very pleasant, considering the place. I passed the word of day with him and kept on, declined the apparent disposition he seemed to evince for a parley. I was suspicious, and as I kept on I slightly turned my head so as to keep him in view, and I saw that he had stopped and was regarding me, and he called out, asking if I had met any one before him as I came down, to which I answered "No," still keeping on, as I observed his right hand was on his pistol handle, where mine went without delay, as I was armed, and I kept steadily on, still keeping him in view and left him standing where he stopped, and the turn in the road soon left him out of view. I had not gone far-perhaps 
twenty rods-when I heard a pistol shot ring out from the place I had left him, but being quite out of range I presumed that in the half-maudlin state he was in he perhaps had taken a stray shot at one of the red squirrels, which were plentiful along the ravine.

When I arrived at Brune's I told him of the occurrence, and he said the man was one of the bushwhackers who belonged to a gang which was camped up the stream a mile or so above, and that the chap had passed the house not long before and had stopped to ask for a drink, which could not be furnished. We had supper, and after taking a quiet smoke and talking over the inexhaustible subject of fishing, a man entered with a lantern, being a neighbor, saying that he had just come down the cañon and that there was a dead man lying in the road not far above the bend, who had evidently been shot and robbed, judging from the loose papers lying about him. Our glances were significant, and we saw that the man following me had been shot and robbed. We got two or three men to accompany us and all went up there, and found the dead man lying on his back as left in the road, with his face upturned and as placid in the full moonlight as if sleeping. Near, on the side of the road, where it had been carelessly thrown, was a long breast pocketbook, which had been stripped and from which the loose papers had been thrown out. We rigged up some boards from the floor of the old cabin, carried him down to the Bar, depositing the body in an adjacent shed, and hunted up the Assistant Sheriff of the place, who declined to go after the murderer that night, but would in the morning, and did, but found no trace of him, and the matter was dropped. 
The murdered man had no name or paper about him by which he could be identified, and a rough box was made for his interment, which took place the following day. The grave was not very deep on the side-hill, and no more than two or three besides our party attended the burial. Brune got out his old Episcopal prayer-book and read the burial service. As he was reading, down the road came a dozen bushwhackers riding as if in a race. When they saw us on the hillside they abated the speed of their horses and came up to us, inquiring what was going on, and on being informed, one of them dismounted and, giving his horse in charge of a companion, said: "I will make a prayer for the dead man," and, kneeling by the grave, gave a frightfully blasphemous prayer for the dead, remarking as he remounted, "That will save him from hell." They all then rode off at a racing speed and we saw no more of them. We remained silent during the interruption, and afterward Brune proceeded with the service. The grave was filled and a pine board was placed at the head, which probably soon disappeared from the action of the elements. This narration, so strictly accurate, indicates the condition existing at the time.

Going down to Denver to arrange for my departure to the Central Parks, I was surprised to meet there two friends of mine from Boston, Daland and Twing, who had arrived for the same purpose I had, and they readily agreed to accompany me on the proposed excursion. Supplying ourselves with horses and provisions and two assistants-one a good guide and hunter, and the other the unfledged millionaire I before referred to-we started off in good spirits. In three 
days' travelling we arrived at the South Park, where we established a permanent camp. We found good hunting and fishing, but the trout very very tame and dull on the line, though good eating. They had neither the beauty nor activity of the Eastern trout, and acted when hooked less gamy than Eastern chubs. These trout were so tame-and I generally found them so in Colorado-that little skill was required to catch them. and $I$ have seen men on horseback following a stream and jerking out many trout with poles and baited hooks. I presume they are now educated up to a more critical standard.

All fishermen who have fished over varied sections have doubtless observed how fish vary in their boldness or shyness. There are, of course, the particular fish who may have been hooked several times, and have become very shy and very difficult to catch; but I refer to the general class of fish in streams and ponds or lakes as affected by frequency of fishing. There are many shades and degrees of shyness between the trout in waters which have not been fished and those which, for instance, are in the Thames and streams of England, where the greatest caution is required, and where the method of drawing the fly across the water, as pursued in this country, is of little avail, and where only the smallest kind of flies can succeed, and only where they are quite dry and can float with the current down-stream on the surface, in imitation of the delicate ephemera. Connected with the smallest thread of gut, they must the moment they are wet be exchanged for perfectly dry ones. It surprises many Europeans to be informed that our largest trout can be taken successfully by a large No. 2 or No. 3 hook, 
with a spread of an inch, and drawn through the water a foot or two below the surface, and that trout will strike at such a fly several times in succession and often when pricked by an unsuccessful strike.

The trout of the Rangeley Lakes are particularly gamy, and it is with some hesitancy that I say, for fear I may be discredited, that I have several times when trolling with fresh minnows caught trout which I have reeled up within twenty feet of the boat and lost off, and had them in plain sight seize again the mangled minnow and hook and be netted into the boat for their temerity. The salmon is very cautious in the fresh-water pools in taling the fly, and if unsuccessful in its strike will retire to its first place and take a rest before rising again. In the Pacific Ocean, when following a trolling bait of fresh anchovy or sardine, it will exhibit great boldness and tenacity, comparatively fearless of the boat, and will strike savagely at the bait, and if not hooked at the first effort, but getting a portion of it, will hook on the remnant when often but a skin shred remains, and within ten or fifteen feet of the boat, plainly visible in the clear water, and several following will sometimes be observed in chase.

In the Park we found game plentiful, antelope and deer especially. One morning we observed a mile off a large bear feeding in the tall grass in the open. The wind was favorable for our approach, and a projecting group of timber on our left reached out for a good station to fire from, and although our hunting guide, experienced with bear, was absent for supplies, we concluded to take in the bear ourselves if possible. We worked up through the timber, and when we arrived at the lower end of the wooded point we found 
the passage was badly blocked by windfalls, which we had much difficulty in getting through, particularly at the point we wished to arrive at.

We had to climb over lots of logs and branches and expected that the bear would take alarm, but when we came near the end of the point and could look out we saw our bear still feeding undisturbed. But such a monster we had never seen before, and he looked to be the size of an ox. I began to feel an apprehensiveness I had not before, and I whispered to Daland and Twing, asking if they thought we had better go on in our purpose, considering the surroundings and the possibility of escape in case of wounding the bear if he should drive for us. I made a mental calculation in this wise: What is the bear worth to kill? Perhaps a hundred or two hundred dollars. What is my life worth to me? More than several millions of worlds. I don't believe it is a reasonable proposition and I decline. Twing was inclined to risk it, but Daland thought as I did. We very cautiously returned the way we came.

Our great bear hunt was over. Our hunter guide, when we related our experience to him, considered that it would have been very imprudent for us to have shot at the grizzly, and related the experience of a hunter friend of his who at this time was laid up in the North Park, whom they called "Old Kentuck," terribly bit up and mangled by a grizzly which came upon him after being wounded, and it was a question if he would recover.

Mr. De la Vergne afterward related to me his experience with a grizzly which he shot at from a repeating rifle while out prospecting for mineral ores. The 
grizzly was not far off, coming leisurely toward him. Mr. De la Vergne crouched behind a large fallen log and, taking deliberate aim, fired at the bear's breast. No sooner had he fired than the bear, giving a savage growl, came for him, though not at full speed, as he was badly wounded, and received three more shots, dropping finally in a death struggle within twenty feet of Mr. De la Vergne.

A man whom I afterwards employed named Sawyer-more of a miner than a hunter,- while taking a mule pack of provisions over the range for me, was suddenly confronted by two large grizzly bears on the trail, whose sudden appearance stampeded his mule away from him, which went off at a galloping rate with its load of provisions and Sawyer's rifle, and the poor fellow had barely time to get up a tree before the two bears were on the ground below. They kept him up the tree for several hours, and he did not recover his mule until the following day. The mule, when found, had made his way to Breckenridge, the nearest settlement, eleven miles from the scene of the disturbance.

Fortunately the grizzlies are not good tree-climbers, unless aided by low-down branches which they may seize and which are sufficiently strong to bear their weight.

\footnotetext{
A FTER two weeks' stay in the Park, we crossed A over the range to the headwaters of the Rio Colorado, in the vicinity of some gulch miners on the California and Georgia gulches, where they were taking out some very good gold nuggets of fine gold.
} 
I purchased some of the nuggets, one of which weighed a pound, for which I paid three hundred dollars, and altogether I bought nuggets to the value of two thousand dollars. It then occurred to me that I would make a collection of Colorado ores, which I did, building up from the nuggets bought, and when I returned to Central City I employed several men to follow up the opened mines in Gilpin and several other counties, until I secured a large and representative collection from several hundred mines, which I afterward exhibited at the World's Fair in Paris in 1867.

I also secured specimens from the few opened mines then shown up over the range, which from assays made at the Denver United States Mint I found to be distinctive from the ores about Central City, and more predominating in silver than gold, which induced a belief in my mind that the over-the-range mineral veins would ultimately make a record in the silver line, which was not then expected. In fact the general view existing at that time was that Colorado was wholly a gold-producing region, and that silver was an incidental feature of no particular importance. I was so much impressed with the value of the silver mines from the Denver assays that I wrote a small book on the subject, entitled Silver Mining Regions of Colorado, of between one hundred and two hundred pages, of which I had five thousand copies published by D. Van Nostrand \& Co. of New York. This gave an account of the silver mines, with a general history of Colorado and its mining methods, and was the first work published on Colorado. This work, published in 1865 , was severely criticised by the gold-mining region newspapers, and in some instances ridiculed as preposterous and 
one that could only have been indited by one of the tenderfoot order, ignorant of the real wealth of the State.

The working of the silver mines at Leadville a few years afterward dispelled the gold monopolizing theory most effectually, as that region has yielded up to the present time a good deal more than a hundred millions of the white metal.

As my work published in I 865 is out of print I will intrude some extracts in verification of the prophecy I then made:

"The silver fields now discovered in Colorado, upon the western slope of the range, but a short distance from the gold belt of veins, are apparently in prominence and value beyond any known in the world, and the results that will be realized there within the next few years will constitute an epoch in the history of silver mining. Were it generally known to-day how rich and inviting the silver fields of Colorado are we should witness an attention and investment there more conspicuous than any exhibited before during the present age. An excitement of magnitude is inevitable and will come."

"The wealth of the mines of Mexico is historic. We are informed by Humboldt in his Essai Politique that 'the yield of the Mexican mines since the conquest to 1803 had been $\$ 2,027,952,000$, all of which was produced from a few central spots, and the mining confined to a comparatively limited circle.' The registered coinage of the Mint of Mexico, from the years I 733 to I860, shows $\$$ I, 74I, 573, I07.

"The following registered yields of a few Mexican mines may be interesting to the reader: 
Biscaina vein................. \$ $16,341,600$

Santa Anita vein.............. 21,347,210

Valencia vein................... $31,8 \mathrm{I}_{3,486}$

Rayas vein.................. 85,42I, OI 4

Veta Madre vein.............. 225,935,736

"The Pavellon vein when first opened was said to have produced $\$ 20,000$ per day for five years, when a torrent of water from the mountains filled its shafts and swept away the improvements. It was opened again, and for the succeeding ten years yielded $\$ 60,000$,ooo. In 1696 it was once more abandoned and not opened again until $I 787$, when it was vigorously worked for eight months. The ore taken from it in that period yielded $\$$ II,500,000. The different members of the noted Fagoaga family are estimated to have received during fifty years' working of two veins over $\$ 16,000,000$ in profits.

"That the great mineral treasures of Mexico commence at the point where Humboldt rightly states the labors of the miners to have terminated, is conceded by those familiar with the country north and south and the natives themselves. We may be surprised when considering this fact, that such localities, known to be so much richer than the interior sections, should have been so long neglected.

"The extreme northern mines of Durango and Chihuahua have been proven as vastly richer than those of the interior. It is upon the records of Mexico that one Señor Zambrano, proprietor of two mines at San Dimas, Durango, paid as the king's fifth upon the silver raised from the two mines, from I783 to I807, the sum of $\$ I I, \infty 00,000$. Nothing but the extreme richness of the ore could have paid the royalty of the 
King, and the heavy duties entailed by the distance of those mines from the Capital.

"The Carmen vein, north of Durango, in the State of Chihuahua, among the mines of Batopilas, upon the western declivity of the Sierra Madre, has produced enormous yields of silver. From this vein three masses of pure malleable silver were taken, weighing collectively 870 pounds.

"The mines of Santa Eulalia, in Chihuahua, are the most northern of any mines in the Mexican States which have been worked with any regularity, and proved by the richness of their ores the superiority of the northern mines of Mexico over those of the interior and southern part. The registered yield of the mines of Santa Eulalia from I 705 to $\mathrm{I} 737$ was $\$ 55,959,75^{\circ}$, or an average of $\$ 1,748,742$ per annum; from I 737 to I79I the yield exceeded $\$ 44,000,000$, making a total for eighty-six years of $\$ 100,000,000$.

"This extreme northern district was abandoned in the year I 800 from its proximity to hostile Indian tribes, whose savage incursions could not be prevented by the mining population, who received no assistance from the Mexican Government, which was engaged in civil discord; and the flourishing haciendas for reducing metals, which were once in such a flourishing condition, are now a mass of ruins. Thus the tantalizing wealth of the northern mines of Mexico and the rich tracts of Arizona and Colorado have remained undeveloped until the present day.

"The report of Mr. Glennie, a very enterprising and intelligent English traveller, who made, in the years 1824 and 1825 , a number of excursions over the northern Sierra Madre range, confirms the good 
reputation these unsettled tracts have had in the estimation of those familiar with the northern mines of Mexico.

"A single instance of the result of an exploring expedition by some Mexican buscones (searchers) into the regions of Arizona (contiguous to Colorado), in the commencement of the eighteenth century, will illustrate the wealth of that region. Upon their return they brought most wonderful accounts of richness, and, in proof, 4033 pounds of pure silver, one mass of which alone weighed 108 arrobas, or 2700 pounds, the largest mass of pure silver ever found in the world. The fact is well substantiated by record. The claims of royalty to the King being disputed by the explorers, led to a long and vexatious suit resulting in a royal decree of Philip V., dated Aranjuez, May 28, I 74I, which terminated a prosecution by the Royal Fiscal against the discoverers of Arizona, and gives the weights of the balls, sheets, and other pieces of silver discovered (bolas, planchas, y ostras piezas de plata).

"The decree ends by declaring Arizona to be royal property as a 'Criadera de Plata' (a place in which, by some natural process, silver was created). In consequence an end to enterprise in that region occurred and it has remained until this day comparatively unknown and infested by hostile Indians. An attempt to found a colony there to work the mines upon royal account was made, which owing to want of support failed.

"The following extract from the report to the English Government by H. G. Ward, Chargé d'Affaires to Mexico for a number of years, may not be uninteresting in view of the developments of the silver regions 


\section{A Sportsman}

of Colorado. The report was published in the year I827 for the benefit of English capitalists who had invested largely in Mexican mines, and was the result of a long and critical examination of the mineral resources of the country.

" "The hitherto unexplored regions in the north of Mexico contain mineral resources which, as discoverers proceed, are likely to make the future produce of the country infinitely exceed the amount that has been hitherto drawn from the comparatively poorer districts of the South.' The specimens which I have seen of the ores extracted from about $36^{\circ}$ north latitude almost induce one to adopt the theory that the proportion of silver contained in the ores increases as you advance north, a theory which is generally believed at present in Mexico, and which is certainly confirmed by the superiority of all the northern ores over the richest districts in the South.

"The line of Mexico at that time extended along the Arkansas River to the ${ }_{2} \mathrm{~d}$ parallel, which included the regions of New Mexico, Arizona, and Colorado; the line of Colorado commencing at $3 \mathrm{I}^{\circ}$ and ending with $4 \mathrm{I}^{\circ}$ north."

These were some of the arguments included in my published work of 1865 , prior to the discovery of silver in Colorado. The results of mining in Colorado and Utah and regions beyond have fully verified the prophecies given in 1865 as to increasing mineral values as mining has proceeded northward from Mexico.

Over the Range, Mr. Tabor, afterward Governor of Colorado, and briefly a United States Senator, was engaged in keeping a small station, where we purchased supplies. We were camped near a large body 
of Ute Indians at peace with the whites, who were engaged in their usual life of hunting, and whose primitive methods of life were interesting and amusing. They would come over to our place frequently in large groups, especially women and children and young braves, and would sit on the ground for hours watching our every movement, until it became so annoying that we removed our camp farther off. These Utes, with the exception of trifling small outbreaks, have always been at peace with the people of Colorado, and are now removed to a distant reservation. They never indicated any disposition to enter our camp, though they would get about as near as they could without getting in, and the intense interest with which they would watch our dressing, washing, and cooking was most amusing, and when one of us shaved they would pack the front of our humble abode so densely as to make it difficult to pass through them. Yet they never molested any of our articles, or opened our closed camp during our absence, although we did suspect that they had stolen two of our saddle-horses belonging to Daland and Twing, two white mustangs designated as General Grant and General Sherman. We informed the chief of our suspicions, and he admitted that he feared some of his young braves might have got away with them, which he very much regretted.

All of our horses were stampeded one night, and we found in the morning that they were all gone from the place where they had been picketed, and half a dozen Ute braves volunteered to join us in search for them. The Indians were very efficient in trailing, and followed the horses to a burnt-over hillside, where the young grass had kept them at grazing-all but General Grant 
and General Sherman, who were nowhere to be found, though one of the braves claimed to have discovered their trail, taking a straight course for the town of Breckenridge, which we had passed through on our route over. We viewed the statement with some suspicion, and were inclined to think he knew more about their disappearance than he might be willing to admit.

A few pounds of sugar and a dozen cards of common matches amply rewarded our assistants in the search, for sugar and especially matches were the usual articles mostly prized by the Utes, and they asked for these articles more than for anything else. A knowledge of this demand led us to lay in a good stock of matches, and in a sudden burst of benevolence one of us would occasionally at camp go among the group of Indian visitors and gravely distribute two or three matches to each one. These would be received with many expressive grunts of gratitude, and the precious illuminators would be carefully wrapped up in strips of buckskin and stowed away.

It will be related later on how we recovered Generals Grant and Sherman afterward, at a distance of over one hundred and fifty miles from where we lost them, showing that any suspicions we had that the Utes had stolen them were groundless. The Ute Indians, always peaceful with the whites, were perhaps more so than they otherwise would have been, but for their situation as mountain Indians inhabiting the parks and surroundings in Colorado. On the plains below were the Cheyennes and Arapahoes, always at war with the Utes, and on the other side of the Utes were various tribes of Indians hostile to them. If they had war with the Coloradians they saw that they 
would be driven into the hands of their enemies. They could sustain themselves in their mountain regions against other tribes, and though they annually descended to the plains in the buffalo season, and had frequent conflicts with Cheyennes and Arapahoes, they could retreat to the foothills and hold them off. They were as superior in the hills, as the Cheyennes were on the plains. Frequent conflicts of this kind were witnessed in the early days by the white settlers, and one off the town of Denver was witnessed by the people there the year I arrived in Colorado.

In I 879, when I arrived at Leadville-which then was the scene of a most remarkable excitement, arising from the discovery of the rich carbonate silver ores two years before-I was struck with the resemblance of the locality to that where we found our strayed horses fourteen years before, and upon mentioning it to Governor Tabor, he confirmed my impression that it was the identical tract, as he was a near resident at the time and noted the incident of our finding our horses on the burnt tract, and this my hunter-guide, Utter, whom I found at Leadville, also affirmed. The town was crowded beyond its capacity, and many were occupying tents and temporary shelters; not very comfortable, the latter, as it was midwinter, and at an altitude of nearly ten thousand feet above sea-level. Large sums were being taken from the mines quite near the surface, and the struggle for wealth reminded me of the old times at Oil Creek in I865. I naturally thought of my early visit there, when such untold wealth lay beneath my feet, and when an acquired title of one hundred and sixty acres of land from the government would have had more than a value of 


\section{A Sportsman}

$\$ 100,000,000$. But I saw no evidence of the slumbering wealth when I was there, or mineral indications enough from which to obtain specimens for my collection, though we did not look very attentively.

The day after my arrival I saw a small tract fifteen hundred feet long and six hundred feet wide, which has since yielded over $\$ 10,000,000$ in silver. I purchased for some friends of mine a part of this tract one hundred and fifty feet in width for $\$ 300,000$, which yielded a ton of silver per month for over two years. The silver ore found and worked primarily at Leadville was found in a blanket-spread form over and below the surface, instead of going down vertically as found in fissure veins, and was combined with a carbonate of lead This blanket deposit was pretty well worked out in a few years, and mixed with it, and below were large bodies of iron ore, worthless for silver, but with an admixture of manganese, making it valuable for flux in smelting, and especially valuable in the manufacture of Bessemer steel, so that the anomalous condition of many of the silver mining companies was exhibited, after the exhaustion of their silver ores, as existing by furnishing material for steel rails.

We made a third removal of our hunting camp over to a beautiful and grassy but limited valley on the headwaters of the Blue River, a tributary of the Rio Colorado, at the base of a precipitous and rocky mountain which we named Fletcher. This mountain, one of the most prominent of the continental range, towering up fifteen hundred feet from the little valley we occupied, was very difficult to ascend, and rather dangerous on account of loose rocks of mammoth size, which needed but little encouragement to go crashing down 
to the valley below; and we amused ourselves when making the ascent by prying over rocks, which dislodged others, and at times made avalanches of large proportions, and when we reached the sharp, ridgy extending top it became a question which side we would create an avalanche upon from the tottering rocks thus easily dislodged-if we would give them to the Atlantic or Pacific side.

This mountain, so precipitous and having no timber, being at its base above the altitude where it would grow, had a good many small areas grassed over, and all these spaces indicated the visitations of bighorn mountain goats, which were plentiful compared with other localities we had visited. Inhabiting this mountain through the summer they would descend habitually to the small fertile valleys below for grazing, but at the least alarm would break for the heights, and could be watched going along the most precipitous passages with a celerity that was astonishing. We killed eight during our stay, and found them fairly good eating, excepting one or two old stagers which were rather strong for our taste.

We got nearly all of the bighorns on the mountainside, by spotting and cautiously approaching the small grassy areas when the wind was blowing strong from the opposite direction of approach, and frequently the odor arising from their resting-place would be the first intimation we would have of their near vicinity. One of the gulch miners at McNulty, some miles below us, had a tame one, captured when a kid, which was a1lowed to run about without its attempting to go away, and was rather offensively tame in its close hanging on. 


\section{A Sportsman}

How these goats survive the severe storms and snows of winter I can not understand, but they necessarily must descend to the milder regions of the parks. Still, the mountains have many sheltered valleys where feed exists through the winters, and I have since noted at Cripple Creek, at nine thousand feet elevation, that domestic cattle feed out during most inclement winters.

The view from Fletcher Mountain was of wondrous interest in its panoramic display of mountain ranges, exhibiting the small tributaries of the Rio Colorado and the Arkansas River. The many small rivulets in commencement seemed almost connecting, but separated in resulting termination, - originating together, one system to mingle in the briny waters of the Atlantic and the other in those of the Pacific. We found trout plentiful in all the streams of the same class as found in the parks, brownish with black spots, but no carmine coloring.

We noticed some peculiarities arising from the high altitude we were at, when water boiled at so low temperature as to take from two to two hours and a half to boil our potatoes soft enough for eating; ten minutes to boil an egg medium well done; and beans one could not boil long enough all day to crack the skins for baking. Being scalded by boiling water was out of the question as understood at low altitudes.

We all felt the difficulty in breathing incidental to the rarified atmosphere, and in ascending an elevation frequent stops were necessary. We found, however, some relief in this respect after some days of stay. Our horses were affected the same way, which necessitated much caution in using them freely. It is questionable 
if any one born and habited to low altitudes can ever become as efficient in physical ability in extreme high elevations as if born there.

In Ward's Mexico it is related that Englishmen there brought out greyhounds to course for the hare, plentiful on the elevated mesa lands. The greyhounds were found inefficient, but the offspring bred there were found successful in the chase.

$A^{S}$ elk did not abound in our locality we again small stream tributary to the Gunnison River, which in turn flowed into the Rio Colorado. Here we located near the Divide, where we found more game than we had yet seen in Colorado,--bear, both grizzly and cinnamon, bighorns, elk, and deer in abundance, and mountain lions. We had but little desire for bear meat, and were quite satisfied in witnessing the signs.

We killed several elk and deer, and finally a mountain lion, after many miles of tramping, and having about given up the hunting, having no dogs suitable for following, as our three dogs were of a mongrel kind and untrained to such sport. They, however, one day in advance of us, surprised a lion at the remnants of a deer we had killed, which almost immediately treed, instead of making off as usual for rough and difficult grounds. A single shot brought the lion down mortally wounded, but with life enough left to very badly mutilate one of the dogs which too abruptly rushed upon him. He proved to be a very old one, and thin in flesh, but with a large, fine pelt, which we carried out with us in our collection of elk horns, bighorns, 
and deer skins, which required an extra pack-mule we had to purchase.

It required one hundred and fifty miles of travelling to get back to Denver by way of the South Park over a very rough country, until we reached the plains. At Denver, where we rested for two weeks, I met two young men from Boston whom I knew, Abbott and West, and after exciting them with tales of our adventures, we planned together another excursion to visit the Middle Park over the Divide by way of the gold mines in Gilpin County.

We found Denver being diminished in its population from the hard times existing. The known surface diggings were becoming exhausted, and no methods were known how to work the stubborn sulphurets beneath. In the two years following Denver probably lost one third of its inhabitants, who by driving teams or on horseback, or by one way or another managed to get away from a region where they saw no means of livelihood. Real estate sunk to a low ebb, and many owners, from either want of funds or faith in future values, let their property taxes go unpaid.

It was not until I 868 that the smelting process as pursued at Swansea in Wales was introduced, and from that period a growing prosperity occurred, and now the State surpasses any in the Union in its yield of precious metals, with agricultural products of still greater value.

It was now midsummer when our party, increased to five, returned to the mining sections, resting for a few days. Supplying ourselves with pack-mules and two hunter guides, we essayed a route recommended to us over the Divide from Spanish Bar by Trail Creek, 
which was ill-advised, and which we could not make owing to its roughness, with accumulated snow in the passes, although it was the first of July. We had expected an additional guide familiar with the route who had a camp at the lower end of Trail Creek, but he had struck some rich surface pay ore on the Freeland Lode near by that was too attractive for him to leave, but would send up Dixie with us to the end of the creek near the Divide. We supposed he meant some companion of his, which he did, though it turned out to be a longeared donkey, which he assured us would most faithfully take us through to the Divide if we would keep him ahead and not let him turn back, and we might let him return alone when we got through with him. This gave us a good deal of amusement, besides creating a suspicion that we might find ourselves on some sort of a wild-goose hunt before we got through, which turned out to be the case. We were at the end of the settlement, and the expected man, Holland, could not or would not go, and we had no resource but the donkey.

It was early in the day when we started on over a trail, which, distinct enough on the start, soon gave out entirely. We, however, kept Dixie on the lead despite his frequent evinced determination to go back. We had the running creek anyhow for a guide, and we could not lose that, though we had to cross it a great many times, and had to leave it often and go around hills which were too precipitous to climb, or which met at the stream where no passage existed on either side. Our objective destination for the day was Chicago Lake, so called, near the summit, which was a pond about half a mile in width, and noted under the romantic name it had, as having been the locality at which 
Bierstadt had painted his celebrated picture called The Heart of the Rocky Mountains - a very striking and attractive picture of which there have been many lithographs.

At times in getting away some distance from the stream it looked as if Dixie was leading us wrong, but he brought us round all right, except in one instance, when he struck up a hill so steep that we had to dismount and hang on to the tails of our horses and mules to keep up with the procession. We felt sure he was wrong this time, but how to stop him was the question, as he kept on ahead, and we were too winded to overtake him. By calling a rest, however, Dixie began to let up and nibble at the scant feed, and one of our guides finally got ahead and turned him back. We had taken the advice of Holland, which proved a good precaution, and loaded up Dixie with a pack to flatter him that he was of sufficient importance to belong to the excursion, which no doubt had a salutary effect upon him.

It was near dark when we arrived at the lake, which was the head waters of Trail Creek, beautifully situated in a moderately opened valley, surrounded upon all sides but the one of approach by uprising, precipitous ledges of rocks. We were near the Divide, and had in our ascent risen over three thousand feet from Spanish Bar in going over a distance of twenty miles. Rising up ahead of us was a battlement of rocks several hundred feet in height, bare of timber and covered with snow. This constituted the dividing line of height between the Atlantic and Pacific, and was the pass we were to go over. From the pass on each side were rocky ridges rising hundreds of feet still higher. 
The snow extended down from the summit to the shores of the lake, and as we remained here for several days we celebrated the $4^{\text {th }}$ of July by efforts at snowballing and coasting. The ice had gone out of the lake but a few days before. The last reaches of timber ended at the lake in small, scraggly diminutive pines, though in Bierstadt's picture large trees are shown, and an Indian encampment with peaked and picturesque wigwams.

We did not arrive so late but that I could try the fishing, while the rest of our party prepared the rough shelter for the night and attended to other duties of high life. Somewhat to my surprise I found the trout plentiful, and soon had a school around me and secured a score, all averaging about the weight of half a pound. They were very listless on the hook, with bellies full of ground and surface feed, bugs and ephemera, and I was surprised that in such condition they should take my bait of fresh meat so readily. Curious that trout should ascend so high, showing the wondrous adaptiveness of this fish, which has no limit to its venturesomeness if the cardinal virtues of aeration and low temperature are present. Yet this lake is hardly free of ice for more than three months in the year.

Twing, who was a good deal of an epicure, claimed that he must cook these trout for supper himself, to insure their favorable condition for the satisfaction of a hunger which was keenly felt after our laborious day's work. Daland and I felt some misgivings at this declaration, as we had experienced some of Twing's culinary efforts upon previous excursions. However, we let him go on, but when in our eager expectancy the trout were brought on, the dish was greeted with 
a cry of sorrow and disappointment that made Twing very unhappy. He had cut up the trout in squares like dice, and while frying them in the large camp saucepan over the open fire, the fat had ignited and before being extinguished gave a charcoal hue to the squares which was far from appetizing in appearance or taste. This led to a raillery on the subject which completed Twing's discomfiture so much that he soon sought the retirement of his soft bed on the fragmentary sticks which were laid over the damp ground for resting upon.

Our extemporized camp for the night, owing to the scarcity of material, was of a sparse character, better calculated on top for a survey of the skies than protection in case of rain, but the night was clear though very cold, and our supply of dry wood was too limited to last satisfactorily through the night, compelling a forage for more toward morning. A little incident occurred which still further affected the situation.

Twing, retiring earlier than the rest, commenced a nasal serenade of an amusing character, at which Daland, a persistent joker, tied a few of our emptied tin cans on the end of a stick and thrust them over Twing's head from the rear of the camp. Jingling these tins at a merry rate soon aroused Twing who, tired and irritated at the intrusion, threatened to pull down the whole camp if he were disturbed again in the same manner. In a short time he was off again on the musical tour, and Daland applied again the counterirritant. Twing was as good as his word and, rising in his might as Samson of old at the pillars of the temple, upheaved the supports and we were campless in a twinkling. It was little loss, however, and we 
weathered out the night with none missing at the breakfast call.

We sent off the men to look for a pass to get over the Divide, who returned in a few hours with the information that there was too much snow to think of getting our animals over, as it was soft and honeycombed beyond any possibility of safe passage. During the day we tried the fishing with success. A11 the trout were as full as they could be with ground feed, and and showed no fear at our approach. We had some cooked properly, but they were not high in the standard of flavor. While Abbott was fishing along the lake shore some distance from me, my attention was attracted by his firing his pistol several times, and while watching him, saw that he was wading out in the water and firing at something on the rocky shore. I hastened toward him and saw half a dozen small animals on the shore by the water edge chattering at a great rate, but which scurried away among the rocks as I came up, and found that he had shot at and wounded one, which set up a cry of distress which brought out a number, whose threatening aspect compelled him to retreat into the water, when he continued firing at them, but without killing any, and was as I came up reloading his pistol with another round of cartridges. I did not see one closely enough to particularly examine, but the guides said they were mountain woodchucks, with which they corresponded in size and general appearance, but were not the animals of that name with which we are familiar and I noted they had tails ringed somewhat as a raccoon. We remained over three nights at the lake, but in a more comfortable camp than our first one. Dixie, who piloted us back to Spanish Bar, we kept tethered. 
After reaching the Bar we took up Fall River Creek on our way to Central, and met here one of those immense swarms of grasshoppers occasionally encountered in Colorado. The air was full of them, immense full-sized grasshoppers, near the earth and reaching up as high as we could see, so that in looking up they resembled a heavy passage of snowflakes. They were coming from an opposite direction and struck us so steadily that we had to cover our faces with our handkerchiefs. They were drowned in immense numbers in the waters of the stream, and swirled away in the currents by the barrelful.

Amid this storm of grasshoppers we saw two white horses up the hillside, and Daland declared they were Generals Grant and Sherman whom we had lost when we were at the Ute Indian encampment in Summit County, and whom we suspected the Indians had stolen. A closer examination revealed that they were in reality the missing mustangs, and General Sherman was observed to have around his neck two feet of his old tether rope. They were fat and wild, but were secured with some labor, and their backs which were somewhat bruised and sore when lost were entirely healed. Here these two animals had found their way back over the mountains and streams more than one hundred and fifty miles from the present site of Leadville to the old grazing lands of Fall River, where they had originally been obtained from, showing the remarkable faculty which horses and some other animals have in finding their way back to familiar localities without compass or signs which mortals depend upon. I could relate many incidents of this character, of which similar ones are doubtless known to the reader. 
We gave up our expedition to the North Park and I shortly after returned to Boston across the plains by stage, as I came out. When I left Boston for Colorado, I had five thousand dollars in New York drafts given me by three friends, Oakes Ames, of Union Pacific Railroad celebrity, B. E. Bates, President of the Boston Bank of Commerce, and my friend, Peter Butler, to use in the purchase of Colorado mines at my discretion, and I was to have one half the results jointly with them. I brought back those drafts to them, and Mr. Ames remarked that it was the first money, ventured upon an understanding of similar import, which he ever had returned.

IN the autumn of the same year (1865) I made an1 other trip across the plains to Colorado and back. This time I proposed to go through the buffalo country by the Smoky River route, a hundred miles or more south of the stage line, and, having two friends who accompanied me, we bought at the Missouri River a stout pair of mules, with a wagon and saddle-horses, calculating to join a caravan of prairie schooners for protection, and to be a month or more on the road. In the wagon we carried bedding, provisions, and necessary articles. Our object in taking this route and going in this manner was to avail ourselves of buffalo and other hunting, of which we had abundance. From the Missouri River caravans were departing daily, and we had no difficulty in connecting ourselves with one. 
At this period, although the stage line was pretty well protected from the attacks of Indians, the Smoky River route was more dangerous, as the Indians were more or less about there hunting buffalo for their winter's supply of meat. This meat, cut in narrow strips and sun-dried, had good keeping quality for months if kept dry. All the teams as they came along were held up by government officials, who compelled an aggregation of at least one hundred men with each caravan before allowing a departure. Printed regulations were distributed requiring an organization among the men of each outfit, giving rules of proceedings for the election of officers and general management; how to establish picket guards in dangerous localities, and how to provide against attacks. These regulations were important and generally observed.

We had not proceeded many days before we came into the buffalo range, and struck the flank of an immense herd proceeding northward, from which several were killed for use of the caravan. The following day we were in the midst of immense numbers stretched over the plains in all directions. A marvellous sight, one which would impress an observer with the belief that it would hardly be possible to have such numbers exterminated in the brief space of a few years. The building of the Union Pacific and the Kansas Pacific railroads sealed the doom of the buffalo. With the invasion of thousands of hunters brought upon the buffalo grounds by these railroads, who sought no more than the skins of the slain as their reward, who found the buffalo defenceless, without shelter from attack, and of too slow and cumbrous action to escape, it is not surprising that they soon disappeared. 
The building of the Union Pacific Railroad settled the question of annual migration. It had been the habit for unknown centuries of the buffalo to annually migrate back and forth over an immense grazing field eighteen hundred miles in extent, from the fertile lands of Texas to the inclement regions of British Columbia. Once their field of grazing extended from the Atlantic Coast to the heights of the Pacific Sierras, covering more than three quarters of the country, excepting Alaska. The extension of settlements from the East gradually circumscribed their circuit, but nothing more sudden or deadly ever paused their feet or distracted their sight than those glittering bands of endless steel across their way.

Even between the great arms of the Mississippi and Missouri rivers they long held sway, and seventy years ago, when Catlin, the Indian painter, rested at Fort Omaha-which George Francis Train some years ago said was the geographical centre of the Union from east to west, now removed to San Francisco by the outstretching Aleutian Islands, - he said the buffalo were so plentiful that a band of Pawnee Indians, invited by the officers at Fort Omaha, went out and two days after brought in a thousand buffalo tongues for a barrel of whisky. This whisky, i. e., alcohol, was probably seven eighths water from the muddy Missouri, adapted with hot compounds by the kind consideration of the traders to the uncultured Indian taste. And yet, at one blow, the steel rail appearing, said to the stupid and uncomprehending buffalo, Stay, you cannot go around, and in a few years you and your kind of countless numbers, which have so long held the country in vantage, from before history began, shall 
be exterminated. All but a few which your friend the white man shall exhibit in the circus fields or in wirebound parks.

In the buffalo was exhibited the most stupendous feature of large wild animal life ever shown upon the face of the globe, and in later ages it will appear almost incredible to the belief of the reader of history that a condition could have existed to have allowed so many millions of these huge animals to roam at will over the expanse of the greater part of the North American continent; that in modern days masses of buffalo containing from ten thousand to one hundred thousand could be viewed from a single standpoint; that days were consumed by travellers in patient waiting for more than a million of these magnificent animals to pass away before them; likewise to learn that in a brief space of a dozen years from such a condition, a practical extinction of these mammoth creatures occurred. It is a spectacle of grand, marvellous, and pathetic interest.

Coincidental with the passing of the buffalo was that of the plains Indians. Stretching from the Mississippi River to the mountainous backbone of the continent in our day were successive tribes of Indians. which have all disappeared. Their very existence was woven in with that of the buffalo. The real great protector of the Indians was the buffalo, which supplied food, raiment, and shelter. And with the passing of these two great elements of nature, what is left to show their existence? Nothing but a few rude Indian hieroglyphics on the face of rocks and a few mud wallowing pits of the buffalo. Even the bones of the buffalo are not in evidence, all gathered up in the eager 
race for gain after the holocaust of destruction for the carbon works of Kansas, Nebraska, and Missouri.

A competent authority has estimated that between the years 1868 and I880, two and a half million dollars were paid out in the three States mentioned for buffalo bones gathered on the prairies at eight dollars per ton; and if the estimate of one hundred buffaloes to one ton of bones has been correctly calculated, it will be observed that the bones of over thirty millions of buffalo would be required to furnish the amount purchased.

In I870, the year the Kansas Pacific Railroad was completed from Kansas City to Denver, I took passage from Denver to Kansas City over this route, accompanied by three friends, Edward E. Poor, P. Adams Ames, and Clarence Denny. We had been out to California, making a short visit there, and were on our way back to the East. We were attracted by the reports we heard about buffalo being scattered along the railroad route, which my friends were anxious to see, but little did we reckon upon the delay and the apprehensions we were to experience. It was in the early part of April, and the heavy storms of the winter were over. There had been, however, some light flurries of snow and hail, and, although the plains were free and clear, the cuts through which the railroad passed were choked up to some extent with snow and sand, which had to be cleared out, and the forces at the intervening stations were light and inadequate for the work, so that we had constant delays over the route and were five days in making the passage, which on regular time now is made in thirty hours.

Half-way across we came into large herds of buffalo, and in the distance we saw Indians pursuing and kill- 
ing them. The Sioux Indians, although they had been secured upon a northern reservation and were at compelled peace with the whites, had been permitted by the government to come upon the buffalo grounds to secure their customary and usual supplies of dried meat for the coming winter.

Only a year before the Sioux, with the Cheyennes, the Ogalallas, and half a dozen other tribes, who had banded together to prevent the building of the Kansas Pacific Railroad, and who, in $\mathrm{I}^{8} 67$ and I868, swept away the habitations of the settlers and ruthlessly murdered men, women, and children indiscriminately, had been overcome by the government forces under Generals Sheridan, Custer, Sully, and Forsyth, and been placed upon reservations, or at least all who could be gathered up, although remnants of the warlike bands were still loose for moderate forays. The various tribes, still smarting under the ignominy of their defeat and feeling an irritation difficult to entirely conceal, were only restrained by fear of speedy punishment in case of transgression.

We had not known of the government permit for the Indians to be let loose after the buffalo, or we should not have taken this route. We experienced an anxiety difficult to restrain, and as the straggling groups of Indians came anywhere near us, attracted by our train stalled at the face of a snow-filled cut, we prepared for a possible attack. There were but a handful, a dozen or so of passengers, but all men, and with half a dozen shovellers and the engineer, fireman, and brakemen we could muster a score. We had plenty of arms and ammunition, as each train sent out was well equipped by the company, which had fought 
its way across the plains almost from the commencement of the building. The congregated tribes of Indians had given out their ultimatum in 1867 that the railroad should not be built, but little did they comprehend the untiring force of the paleface, which, however temporarily impeded, never ceased in its forward march. The twelve hundred men graded the track and laid the rails on the Kansas Pacific Railroad in less than two years. During the period of building, Colonel Cody ("Buffalo Bill"), under contract with the road, supplied the laboring force with buffalo meat, and with his aids killed over five thousand head.

For two days we had buffalo all about us, and at times it would appear as if they would compel the stoppage of our train. On one occasion a bunch of several hundred galloped on the track ahead of the train for half an hour, despite the whistling of our engine, and others galloped abreast of the train for miles within easy killing distances.

Some days before our passage a west-bound train between Forts Harker and Hays was compelled to lay by for five hours to allow the buffalo to pass. The buffalo in passing repeatedly endeavored to go between the linked cars of the train, and our Pullman car, which was a part of the blocked train, had two of its steps, broken down by the weight of straggling buffaloes, still unrepaired.

While several small groups of Indians engaged with buffalo came within something less than a mile of us, which put us on guard for a possible attack, they did not indicate a disposition to visit us. It had been resolved not to allow any close approach or familiar 
mingling with the savages, but to warn them off if they came within danger limits, but an exception was made on the third day, when we had our greatest delay and our heaviest work in clearing the cuts, at the approach of three mounted Indians, who came at a moderate pace toward us with extended open hands in token of peace. One, who spoke a little English, explained to us that one of the party, a chief, would accompany us until the next day through the buffalo country where so many Indians were engaged, to protect us from any possible attack from young bucks, who might break away from the peaceful promises given by the tribes to the government, explaining that all the Indians were not favorable to the surrender and consequent removal of the tribes from the plains to the government reservations, and that the chief would go with us for our protection against any possible foray.

While this confirmed the feeling we had, that our apprehensions of trouble with the Indians were not groundless, it gave us a confidence which had been failing as to our safety. We therefore accepted this hostage of security with satisfaction, much relieved from the anxiety we had experienced. We endeavored to make the old chief as comfortable as possible although he declined all our advances and proffers of friendship, and sat almost motionless looking out of the car window as the train proceeded. We did not deem it expedient to offer him fire-water, but he deigned without the slightest acknowledgment to accept a handful of cigars and a box of matches, and did a moderate amount of smoking. At the station, hewre we all got out for supper, a while after dark, he indicated a desire to leave us and take the next train back, 
and descended from the car, pointing back in the direction we came from, but the station agent to whom he appealed held a parley with him, and managed to convince him of the necessity of his going on farther, explaining to us that this personal accompaniment of Indians on each train had been arranged for between the big chiefs and the railroad for the period when the buffalo hunts should be along the route. As the buffalo were proceeding north, the present condition would last but a few days longer.

Although a bed had been made up in our car for our dusky companion for the night, he declined to occupy it, and sat stolidly by the car window all night. The following morning, beyond the buffalo range, our Indian left us at a station, where he joined a westbound train, consenting to take from us a moderate purse we made up for him.

WHAT a singular spectacle was presented by our train in the last act of the drama of buffalo and Indians, in the last change in the transition of the plains from wild buffalo range and barbarism to peaceful settlement and civilization.

But the evolution of the buffalo and Indian is no more striking than that of the great Western country which has exhibited such wondrous change.

Ward, the Minister to Mexico from England, upon the establishment of the new government independent of the dominion of Spain, a most sagacious and conservative author, whose work to-day-published in 1827 -is a standard one upon Mexico, said in the preface of his work: 
"The great interior unexplored region lying north of the Mexican States will remain for centuries practically unknown to civilization, and will present to the world the spectacle of the last stronghold of savagery and barbarism to be found upon the face of the earth."

This prophecy was given some eighty years agonot so long but living men can remember the period. But how great was the error of Ward, and how little he appreciated the bold and advancing spirit of man, stimulated as it was to be by the wonderful progressiveness of new agencies. How astonished he would have been, could he have but seen a slight reflection of the present condition through the region which he then accounted as hopelessly given up to desolation for centuries.

Then the population of the United States was less than one sixth of the present amount, and the settlements of the country had but commenced to creep away from the Eastern States. Not until a decade after did the first steamer struggle across the briny waves of the Atlantic, and the first locomotive had just been built. Steam in its application to mechanics had hardly been dreamed of, and the first principles of electricity had hardly been conceived. A belief then in the possibilities of ten billions of dollars of investment in the railroads existing in this country at the present day would have been as preposterous as the opinion now that one hundred thousand millions of dollars may be invested in electrical applications in a century from this date, and the latter opinion will find more believers now than the first proposition could have had then.

Cheap printing and telegraphy, and the general 
diffusion of information by printing and electricity throughout the world as soon as it is obtained, and cheap transportation are leavening up the whole world. Invention, advance, and intelligence are being stimulated as never before, and the progress of arts, science, and general information is more rapid than could have been dreamed of by the optimist of half a century ago.

On my second trip by team across the plains with my two companions in I 865 we were so beset with buffalo that an apprehensiveness existed among the riders and drivers that our stock might be stampeded, as it indicated a tendency in that direction, and at noon it was thought best to hold up for the day and let the buffalo pass, as we had to make a ford over a considerable width of shallow water and sand, over which buffalo were plentifully scattered about. Besides, we had to get grazing for the cattle and horses, which had scant feed the day before. So selecting a spot not far from the river, where feed was plentiful, a large corral was made of the wagons, in which the stock was enclosed. This corral was drawn close at night, as before. A number went out for buffalo, and I regret to say that a good many more were killed than could be economically consumed. One hunter claimed to have killed a group of five without moving from his position. Of these, only the tongues and small parts were taken.

The general method followed on the plains in killing buffalo was that of the Indians, to ride on a fast horse alongside the flank of the retreating buffaloes, firing at them back of the shoulder for a vital spot. Without waiting for the result the hunter proceeded on, engaging with others in a similar manner, and would, 
under fortunate circumstances, slay a number before returning to skin and cut up those first killed. The Indians with their arrows would do great execution if well mounted, and in some instances would send an arrow clear through a buffalo. Much depended upon the speed and management of the mustangs employed, some of which acquired a singular skill and intelligence in pursuing the buffalo, and would in a short time so direct themselves as to require no guidance.

A remarkable instance of this character, well authenticated, occurred in the presence of several army officers near Fort Hays, in I868, where Colonel Cody ("Buffalo Bill") exhibited his unequalled skill in horsemanship and shooting accuracy. Buffalo were about, and a few officers freshly arrived at the Fort started out in conquest. Buffalo Bill, observing a group of eleven buffalo not far off, hastily mounted his famous steed Brigham. Not finding his saddle and bridle convenient, he seized an old bridle and blinders, and bareback started out, overtaking the well-mounted officers, who made some facetious remarks at his presence. He volunteered some advice to the officers regarding the route the buffaloes were taking, and the policy of cutting across in a particular direction which the buffalo, then running, would take. To this the officers gave no attention, and Buffalo Bill, hastily throwing off his bridle, started, bareback and bridleless, in the direction he had indicated. The officers, giving speed directly for the buffaloes, soon rounded them in the direction indicated by Buffalo Bill. The latter, having the advantage of the cut-off, was soon in advance alongside the bounding buffalo, which his obedient and trained Brigham pressed closely in 
repetition of the manner so often followed in previous encounters. Buffalo Bill, before being overtaken by the officers, killed the whole eleven in twelve shots, only one buffalo, the last one, requiring a second shot. The officers, reining up at the fall of the buffaloes which had occurred in so brief a period, were doubly astonished to learn the name of their famous associate.

The dense stupidity of the buffalo largely aided in his destruction. Skilful in protecting its young and running mates from the attacks of wolves, and even the grizzly bear and mountain lion, he never seemed to acquire either a knowledge or a fear of the death-dealing rifle, and many groups of a dozen or more would often allow themselves to be shot down one after another by a concealed hunter, without moving from their tracks. During the death-dealing periods after the building of the Kansas Pacific Railroad, there were hunters who boasted of having killed from fifty to seventy-five buffaloes in a day. The greater part of these killings was solely for the hides, netting often not more than from one to three dollars each.

The exodus of buffalo north, through Kansas, in I868, while the Kansas Pacific Railroad was building, was of enormous proportions. Col. Henry Inman, who was with Generals Sheridan and Custer and a large military force there, relates that they were compelled to lay by with their whole force for three days for the immense swaying mass of buffalo to pass by, and were compelled to exercise the precaution of corralling all their cattle and horses to prevent their being stampeded and lost, and that large numbers of horses, mules, and cattle were lost, and never 
recovered, by the settlers and caravans crossing the plains. Colonel Inman, from a consensus of opinion formed by the officers, estimated that from three to five millions of buffalo were contained in the moving masses which passed north at that period.

The only other parallel case that I am aware of where a large body of animals has held an extensive region in monopoly is that of the kangaroo in Australia, which, sharing the fate of the buffalo, is found now only in small numbers in the unsettled parts of the island, being wholly unknown now in its old haunts. When Captain Cook, in his notable first voyage to Australia in 1770 , brought back knowledge of the kangaroo to the notice of the world, it abounded in many millions over the arable areas of the island continent. They were then as tame as domestic cattle, and a long time after sheep were introduced grazed with them in pleasant companionship. But the sheep men soon found that they restricted the feed, and as the sheep increased, large drives were made of the kangaroos into stockaded pens with extended wings after the manner now followed in Southern California for capturing jack-rabbits, and when taking in a sweep of twenty-five square miles, it was not unusual to capture from three to five thousand kangaroos at a single swoop. Then, the gates being closed, the old male kangaroos being shot as dangerous, the balance were beaten to death with clubs, and after the removal of their skins were left to waste upon the ground.

It is now estimated that eighty millions of sheep are grazed in Australia, and that if the kangaroos were now existing, as originally, not more than ten or fifteen million sheep could be carried along. 
But another animal plague has come in Australia, since the disappearance of the kangaroo, that of the little cotton-tail rabbit, unfortunately introduced by an experimental mistake. These rabbits have multiplied so immensely as to become a serious menace to the sheep industry, and are now estimated to consume the feed of twenty millions of sheep. Large sums have been offered by the authorities for any remedy which would destroy them, but without avail. Although the same rabbits exist in California, they are comparatively scarce, and it has been a wonderment to me why they have not increased. Possibly the coyotes and small vermin destroy them. In Australia they have the dingos or native wild dogs, and the Wallaby bandicoots, native cats, in abundance, but they do not seem to have any appreciable effect on the rabbits.

In the morning we found that the great body of buffalo had passed on north, and we saw only a few scattered groups during the day. We had had enough killing to satisfy us, and having seen all the buffalo we desired, besides antelope and small game, concluded to join another caravan that preceded us, which, being headed for Utah, diverted from the route our caravan was passing for the Platte River to follow the stage road from Julesburg, which place we reached in a few days. There we concluded to dispose of our mule team and horses, and take the stage for Denver. I remained in Colorado a few months, after which I returned by stage to the Missouri River, and by railroad to Boston. 
IN the summer of the following year, I866, I again returned to Colorado, having acquired some interests there, and gave attention to the further collection of ores, of which I already had secured an extensive cabinet. An agitation was occurring on the subject of having an exhibition of Colorado ores at the great World's Exposition to be held at Paris, in 1867, and three commissioners had been appointed by the Territorial Legislature to take charge of the ores and represent them there. The funds in the Territory were scant, and, no appropriation being made, it was necessary that the amount required should be raised by public subscription. This lagged, and it seemed hopeless to expect the amount could be raised.

The intention was to take advantage of my collection, as I notified the Governor that the collection was at his disposal, though I did not care to be added to the number of commissioners already appointed, but in case the amount to be subscribed should not be obtained, I was willing if appointed as sole commissioner to go forward and make the exhibition at my personal expense. To this I received no answer but shortly after returning to Boston, and to my surprise, a few weeks after my return, I received a letter from the Governor, enclosing a commission from United States Secretary of State William H. Seward, appointing me as sole commissioner to represent Colorado at the Paris Exposition. I had all my collection immediately forwarded to New York, across the plains, including all the maps extant, many of which I especially prepared, as well as a large number of photographs. These were shipped by one of the French steamers directly to Havre and Paris in the following 
spring, which I followed in due season. It was my first trip abroad, and my sensations when I arrived in Paris in the evening hour were of an exciting character.

As I was carried through the principal boulevards, so brilliantly illuminated, to the Grand Hotel, the lively and glittering presentation exceeded my expectations, and it seemed as if I had reached a new land of enchantment. The exposition buildings were already completed, and many of the departments were already occupied.

The main building of exhibition, situated on the large open space on the Field of Mars across the Seine from the main part of the city, was oval in form anh over a mile in circumference. The structure was of iron and glass, surrounded by annexes for machinery, agricultural implements, minerals, and various heavy articles. It was intended by the Emperor Napoleon and the French Government to have this world's exhibition surpass any ever before given, and it most certainly did. Napoleon was then in the zenith of his power and France in the height of prosperity.

The American commissioners, a large number, were already there, but the American department was entirely unoccupied. A large number of American exhibitors were there, chafing under the delay in having their various quarters assigned. N. M. Beckwith was the United States Commissioner General and Sam'1 B. Ruggles, of New York, was the second in rank following the chief. Mr. Beckwith had lived with his family in Paris for many years, and primarily in India, from which he had retired with a large fortune. He was a man of singular indecision, lacking executive ability. In vain the exhibitors ap- 


\section{A Sportsman}

pealed to him to have their various places assigned. Time was rapidly passing, and the exposition was soon to be opened, while the American department was dormant and lifeless, and would apparently be behind all others. Several meetings of the exhibitors were held and special committees were appointed to confer with Mr. Beckwith. He promised to act, and, visiting the space assigned to the United States, would mull over it day after day, seemingly confused by the earnest solicitations of the exhibitors. The more he was implored the more he was confused, and finally lapsed into a most incomprehensible stupor when he was approached. Day by day passed away and no decision. In fact, he had been so long in idle life, and without cause for action, that he seemed approaching imbecility. He was, however, sensitive and irritable if the slightest reflection was intimated as to his action. The committee received no satisfaction, excepting in promises which were empty. He had failed to select officers to pass upon the assignments until the crowding applications completely overwhelmed him. I was finally appointed upon a committee to urge his action, and straightway made my appearance before him with my associates. We found him pleasant and affable, and quietly stated our mission. This seemed to throw him into a stupor of indecision, and, clasping his hands on each side of his head, with elbows on the table, he fairly groaned with perplexity. Finally he said, "I will attend to it." I pitied him, but the necessity was urgent. I then said:

"General Beckwith, if the exhibitors' positions are not assigned within twenty-four hours, I shall move for the exhibitors to act in sending a cable to the 
President of the United States, asking for your removal and the appointment of another in your place."

This was a stunner, and the General arose, saying: I do?"

"My God! What do they want? What more can

I rejoined, "Let them go and take their places."

"Let them," said the General; "let them go and take their places. Will that satisfy them?"

"Certainly it will," I rejoined, "and that is all they can desire."

Upon this we made our adieus, thanking the General for his consideration.

As rapidly as a cab could drive us, we hurried back to the general meeting room, which was my salon at the Grand, I having freely tendered it to the exhibitors and commissioners in the absence of any other provided place of meeting at that time.

We circulated the information as rapidly as we could to all interested, and it was great news for the exhibitors. It was a life scramble for place and there was great hurrying to and fro.

I was fully prepared, having completed all my cases and shelving of more than a thousand feet with plate-glass fronts and proper adornments. I had a valuable assistant, a Parisian whom I had employed to constantly guard my collection. I soon had twenty workmen at double pay on the swing for all-night work in placing my shelving, hanging maps, and spreading my ores, and by ro o'clock in the morning I had everything in place, and my assistants were just distributing a plentiful supply of fresh flowers over the top railings, when General 


\section{A Sportsman}

Beckwith made his appearance. His attitude was belligerent and he strode toward me, saying:

"Why, what is this? You can't stay here! This is the centre reserved for pianos, paintings, and works of art. All the minerals will have to go into the annex, where the machinery and minerals are all to go, etc."

I mildly informed him of his assent that the exhibitors were to select their places, and was not the Colorado exhibit as displayed one of the first to be in place, and worthy of the position, and having brought the collection so far over a long distance, would it not be best to leave it as established. But he would have nothing of it and left with much indignation, for I had selected the very centre of the American department, with a liberal extension of some forty feet on each side of an angle, and had the front floor well held down by a few tons of mineral masses, coal, ingots of silver and copper, and other products of similar character. Suffice to say that the Colorado exhibit remained throughout the exhibition in this place.

General Dix was then our Minister to France. Paris was very gay with its large influx of foreign visitors, and the American delegation was largely represented. At least it seemed very gay and attractive to me, so much so that I found it very difficult to do much sober work.

I published fifteen thousand substantial pamphlets on Colorado, one third of each in English, French, and German, all illustrated with a map of the United States and of Colorado, with a list of the ores exhibited, and a general description of the products of the Territory and its history. 
I stupidly left the material of this work to be written when I should arrive in Paris, having the matter in rough outline. I shall never forget the difficulty I experienced in preparing this work. It seemed impossible to get at it. Of course, I had little time after my arrival to do it. I would wait until I had my collection placed, but then I had no time to spare. I was out every night. General Dix was giving weekly receptions. The American residents were giving nightly dinners, dances, and balls. Theatres and operas and official entertainments to which the commissioners were invited occupied much of my time, which necessitated daily visits to the exposition.

With associates similar in disposition to my own, our time was given to restaurants, drives on the Bois, and the races; out every night until the small hours, and sometimes accompanied home by the dawning light, for light comes early in Paris in the summer months.

How I struggled to complete my pamphlet of a hundred pages on far-off Colorado. I never consult that old work without smiling at the sentence which I read over a dozen times or more, and was unable to get beyond it. Describing Denver, pleasantly situated on Cherry Creek: "Rising evenly beyond are higher hills, girt with walls of rock shooting up perpendicularly for hundreds of feet, seeming like embattlements ready to belch forth the crashing weight of iron upon the vales below. Succeeding are ranges of mountains piling in upon each other until they culminate in white peaks at an altitude of from I 4,000 to I 6,000 feet above tide water. These are the 


\section{A Sportsman}

beacon lights of welcome to the weary traveller on the plains, long before he refreshes himself at the sparkling streams of the foothills which they supply."

There I paused to drink water and listen for the echo and reverberations of the battlement artillery. Day after day I would read it over, but could get no farther, and finally had to get Harry Furbush to start it on for me. By the way, he had a very attractive, sprightly sister, quite a belle in Paris at the time. I met her a few years ago. She was living in Rhode Island with her family of nine children. How time has flown since 1867 . It seems only a few years ago. I should be very glad to live it over again.

A very simple friend was Dunlap, from Peoria, I11. One day I dined with him and two others at the Dîner de Paris - five francs, including a full bottle of common Bordeaux. One could, at the same price, change the quart of wine off for a pint of superior quality. When the four bottles of wine were put on the table we concluded one would do for all of us, and I said to the waiter: "Take off this wine and boil it down to one bottle," and he soon returned with it.

The next day I met Dunlap at the exposition, and when about to leave him he said: "I have been thinking what a wonderful people these French are. But I want to ask you how that waiter at dinner last night could boil down those four bottles of wine into one in five minutes and have it come so cold."

The display of minerals at the exposition was very extensive and interesting, all of which, except that of Colorado, were relegated to the various annexes, and when the award of prizes was made I had the satisfaction of receiving the gold medal of 
the first class. This was a large medal intrinsically worth fifty dollars. Upon one side was the raised bust of the Emperor Napoleon and the words, "Exposition Universelle Français, I867," and upon the other my name and award for exhibition of Colorado ores. In addition to the award was a recommendation of the International Jury of special recognition for the exhibit in its completeness, which had been conveyed from such a distant region. This recommendation of the jury to the Emperor, which was made in a few exceptional cases, occasioned an additional expression of high consideration, which I received from the hands of the Emperor at the distribution of recompenses at the Palace of Industry on July I, I867.

France at the period of the exposition was at its height of prosperity, and Napoleon the Third at the zenith of his power and influence.

The Emperor had designed the occasion of the distribution of the exposition awards to be one of unequalled grandeur and effect. The scene occurred at the Palace of Industry on the Avenue des Champ Elysées, midway from the Tuileries to the Bois de Bologne.

This Palace of Industry, of iron and glass, was of stupendous capacity, capable of seating thirty thousand spectators about a central area of large extent. In this area were erected half a dozen large groups representing the various industries, leaving large spaces intervening with a wide promenade around the whole. On one side, centrally located, was a raised dais or platform from the floor of moderate height, and two hundred feet in length, reached by 


\section{A Sportsman}

four or five steps, the whole covered with a crimson carpet. In the rear of the platform was an immense extending canopy with the Imperial coat of arms, and hung with Gobelin tapestry. This was the dais designed and occupied by the principal monarchs of Europe or their representatives gathered by the Emperor to give éclat to the recognition of merit. This presented probably the most distinguished exhibition of royalty ever assembled. Centrally seated were Napoleon and the Empress Eugenie, and adjoining the American Ambassador, the Czar of Russia, the Kings of Prussia, Austria, Denmark, Sweden, Belgium, Spain, and other monarchies, the Prince of Wales, the Shah of Persia, the Sultan of Turkey, Bismarck, and other most prominent European celebrities. The gardens and conservatories of Paris and environs were denuded of flowers to grace the event.

The great musical composition of Rosini to the French people was rendered by a choir of twelve hundred girls in white, with salvos of artillery appropriately timed from the distant Champ des Mars.

Forty thousand troops of the French army lined both sides of the avenue from the Palace of the Tuileries to that of the Industry, presenting arms on the passage of the royal cortège from the former to the latter.

The exhibiting recipients of first prizes, and especially recompenses, by notice given, were gathered in full dress, at a central position in front of the royal assemblage. The opening was declared by the Emperor Napoleon, who advanced to the front and read in a clear and comparatively sonorous voice the few words of opening. This was followed by the French 
Minister of State, M. Rouher, who made a somewhat lengthy address of welcome and illustration of the exposition. The names of those receiving the first gold medal and decorations were then called singly in sequence, and as each name was given the fortunate exhibitor advanced forth from the group to the platform and ascended the few steps to the royal presence and received either from the Emperor or the Empress personally the award.

Despite the august assemblage, all went on pleasantly without delays, and with entire absence of formalities or embarrassment, as democratic as one could desire. Many nods and words of recognition were given by the Emperor and Empress as familiar faces appeared, and much applause came from the audience as well-known figures advanced to the platform.

It was slightly amusing at times to witness the missing back step of some of our confrères in retreating from the royal presence, but every incident of this kind was received in the utmost good-nature with friendly smiles.

The awards of silver medals only to the rich regions of California and Nevada, which had produced hundreds of millions in value, while Colorado had hardly commenced a production, was expressed in much disappointment by the Pacific press. One California paper designated Colorado as occupying an unknown isolated peak of the Rocky Mountains, but its boundaries are now established and well known, and it is the banner State in the Union in its production of the precious metals.

The exhibits from the Pacific mining regions were 


\section{A Sportsman}

limited in extent, and lacking in classification and descriptions, which accounted largely for the slight recognition received at the exposition, quite unworthy of those superior and extraordinary regions whose products occasioned an epoch in the monetary conditions of the world.

NOT long after the prize awards at Paris I was informed by my assistant at the exposition in the afternoon of my visit that the Emperor, in the forenoon, had personally made a prolonged examination of the Colorado ores, accompanied by Mr. Ruggles, our American Vice-Commissioner-General, and this was afterwards confirmed by Mr. Ruggles, who also informed me that the Emperor had requested him to have the Colorado Commissioner visit him at the Tuileries, to whom he would give an audience.

Mr. S. B. Ruggles, the Vice-Commissioner-General to the exposition, was a most capable man of broad and comprehensive views, and the latter part of his life was given in exertions for a general international acceptance of universal standards of coinage, weights, and measures, which undoubtedly will have to come some day, though the conditions may not be ripe yet for acceptance. He told me he was present at the first opening of the Erie Canal.

We had rooms together at the Grand Hotel, two bedrooms and a mutual salon. Despite his age (a little over eighty) he was a regular student, and upon arriving in Paris commenced the study of the French language, and it was amusing to see him up early in the morning in his dressing-gown, with his head as 
bare as a billiard ball, without the fine flowing wig he wore when dressed, intently studying his child's French primer book, spelling out the simple words of cat, dog, rat, apple, and sundry other simple words as illustrated above the spelling. But he made slow headway and was much disgusted with his inability to talk and understand French. But it indicated his disposition for work and his activity of mind, which advancing age had not impaired.

He accompanied me to the interview with the Emperor at the Tuileries, where we received a pleasant reception, quite free from any formality. I had previously had bound up my three exposition works in English, French, and German on large paper, with maps of the United States and Colorado, and a photograph of the Colorado exhibit. This book I had bound in elegant form at the Emperor's bookbindery, where all books added to his library were rebound in pale green morocco, embossed on the front with the Imperial coat-of-arms. This book I presented to the Emperor, who pleasantly received it, and entered into $\mathrm{a}$ conversation about Colorado and its resources. The Emperor spoke English perfectly with but slight accent, and I was rather surprised with his apparent knowledge of the western regions of the United States, and of the northern States of Mexico, and upon my expressing my surprise he informed me that he had lately received for the government special reports on Chihuahua, Durango, and other Mexican States from commissioners sent out for the purpose.

I took pains to impress upon the Emperor the conspicuous importance I believed Colorado would gain in the future from its practically inexhaustible mineral 
wealth, which resulted in his conclusion to have a commissioner sent out to examine and report officially upon the subject. This afterwards led to the appointment of Louis Simonin, author of La Vie Suterraine, a prominent French work on mines, and of other mining works, and Professor of Geology in the French "École des Mines." Monsieur Simonin was also a prominent contributor to the Revue des Deux Mondes, published in several languages, in which after his visit he gave extensive accounts of Colorado and his experiences there.

Our conversation with the Emperor then turned toward Mr. Ruggles's subject of a universal system of coinage, weights, and measures, which the Emperor highly approved of, and remarked that such should be decimal, which France had already adopted. The Emperor asked Mr. Ruggles if he had acquired a knowledge of the French language, to which Mr. Ruggles had to own he knew little of it, but thought he had acquired a slight knowledge until a late incident satisfied him how hopeless it was. A few days before, finding himself confused in a part of the city he was unacquainted with, he thought it an appropriate occasion to air the little French he had acquired, and approaching a gendarme asked him the way to the Rue de Rivoli, for if he could get there he would be all right for anywhere he would wish to go. The gendarme had him repeat his inquiry several times, and then, with a puzzled air, said:

"Pardon, monsieur, mais je ne comprend pas Allemande" (Pardon, sir, but I do not understand German).

The Emperor laughed very heartily at this, in which Ruggles and I had to join. 
I could give many incidents occurring during my stay of several months in Paris, which would lengthen out unnecessarily my details, which might prove of little interest to the general reader, and which I will pass over briefly. One incident of some interest I will relate.

One evening by invitation, I dined with an English friend and his wife at the Café Foy, a small but very superior restaurant near one of the principal boulevards; a gentleman entered to dine whom my host immediately recognized as a friend, and whom he greeted with his wife in a cordial manner, and invited him to dine with us, which he did, and to whom I was immediately introduced, but I did not catch his name in the temporary movements at the table. The newcomer was of jovial and pleasant manner, and made himself at home without ceremony. His evening dress was a little off in necktie, and he wore a profusion of jewelry on his hands and on his heavy watch-chain, and carefully tucked in his napkin under his chin, as if bent on a full dinner, which he had. I was struck with his hearty appreciation of everything we had for dinner, and the vigor of his appetite, which he accounted for by the long walk he said he had taken before in preparation for dinner. His spirits were high and his conversation of the most animated character, which inspired us in a similar way. We had a most jolly dinner, and our stay was prolonged after the other diners had retired. The conversation was general-the exposition, the French people, and the contrast between the French and English fully discussed; the races, incidents, references to friends, etc. Lunching with my friend and his wife the following day, and 
referring to our dinner the evening before, I asked the name of our guest, as I did not catch it, to which my friend answered by saying, "Why, that was Charles Dickens!" I met Mr. Dickens afterward in London during my frequent visits there, and again in Boston, during his lecturing tour in the United States.

I DINED one evening at the house of Émile de Girardin, the noted owner and editor of La Liberté, whose salon, presided over by Madame Girardin, was noted as one of the most social and political centres of Paris. I was seated beside a Frenchman who spoke English fluently, and who had travelled much over the world and particularly in America, and who indicated so much interest in Colorado that I dwelt upon it more than I otherwise should. This gentleman proved to be Mr. Geise, a prominent official in the Crédit Foncier, an important financial institution of Paris.

Before I left Boston, in conversation with Oakes Ames with mention of my proposed departure for Paris, Mr. Ames remarked that as General Dix was there, and President of the Union Pacific Railroad, the French people could perhaps be interested in it, and if so the road would be glad to get a loan there on its bonds. Those who are familiar, as I am, with the early history of the Union Pacific Railroad know the struggles it had to sustain itself in the first part of its building. It was largely discredited in business circles, and found, despite the large gifts of lands given by the government and the government's credit in bonds, that at various times it seemed as if 
the building would result in a failure. Few of those interested in the Crédit Mobilier, organized to carry through the business, believed that any profits would be derived other than those which would be obtained in the building of the road. Mr. Ames, however, believed to the contrary, and but for his own indomitable will and resources the road would not have been carried on in its building by the original promoters.

The conversation with Mr. Geise occasioned his joining the expedition with Mr. Simonin, which resulted in the making of the first loan of $\$ 5,000,000$ realized by the Union Pacific Railroad. Another was added in Colonel Heine, a brother-in-law of Erlanger, the Paris banker, a German of broad views and comprehensiveness, who was actuated by philanthropic motives, as to an opening for Saxon miners who worked hard in their native country for small pay.

I visited Swansea in Wales with the sulphuret ores of Colorado, which were too stubborn for any process known in Colorado, and when shown to the experts of Vivian's great smelting works they occasioned a smile and response that they could be easily and successfully treated.

At this time Prof. N. P. Hill, of Colorado, and afterward United States Senator from that State, came to Swansea and secured the aid of competent workmen and soon afterward erected appropriate smelting works at Black Hawk, in Gilpin County, from which grew the ultimate great smelting works in Pueblo, Col., which have made Colorado the banner State of the Union in mining the precious ores.

- I returned to Colorado from Paris with the parties 
mentioned, taking the cars from Omaha part way across the plains, and then taking stage the balance of the way.

With my associates, Simonin, Heine, and Geise, we left Paris the latter part of September, I867, by the French steamer from Havre to New York and on to Omaha. The Union Pacific Railroad was then completed some two hundred miles out on the plains, and from its termination we took stage to Denver. Our passage by the latter method required four days of travel night and day. The railroad was not then dispatching daily trains, and the semi-weekly one which we occupied was of slow progress on the new road and carried an unusual number of cars, conveying a small body of Mormons for Salt Lake, escorted by an elder of the elect, and several carloads of young western people, going out to occupy lands acquired from the railroad.

Colonel Heine was a large man of rather imposing cast, dressed in velvet with leggings, and, carrying with strap over shoulder a large field-glass case, attracted considerable attention. Overhearing at one of the eating stations from some of the chattering rustics, fellow-passengers, comments about Colonel Heine, and a suggestion from one of them that it might be Brigham Young, I quietly beckoned him inside and told him in a most confidential manner that he had evidently penetrated the disguise of the wily Brigham, and that he had best keep it to himself, or at least not give out the discovery beyond his most intimate and reliable friends who could be depended upon. That Mr. Young, presuming upon his being little known in the East, had perhaps supposed himself unrecognized in his disguise, 
and that probably it would be as well to let him think so, as most likely he was accompanied by his bodyguard of Danites, likewise disguised, and being now so far out on the plains one could not tell what might happen. In further conversation I intimated that it was possible that Mr. Young had been East to get a new stock of wives, as probably with his lively disposition he might have accounted the old stock as stale and antiquated, in view of the improved order expected now to be inaugurated by the passage of a transcontinental railroad. But who knew? No one. Perhaps it would be as well, however, in view of there being on our train a good many young settlers going on with their not bad-looking young wives-it would be as well to keep an eye to windward and prevent, as far as possible, any unrighteous sealing on the part of the vigilant $\mathrm{Mr}$. Young.

Deeming this sufficient, with renewed suggestions of prudence in giving out any information of his detective sagacity, excepting to those whom he could depend upon, I left the future-to-be-chief of a detective department, and at convenient opportunity acquainted Colonel Heine with the rôle he had been assigned, which he was much amused with, and, being a great joker, proceeded at the next eating station to stroll along the platform with a box of seals he happened to have in his portmanteau, ready for action. It was quite evident that the detective had judiciously imparted information by the divergence of the settlers as they passed along the platform by the Colonel, who, holding an open box of red seals in his left hand, held one affixed to the index finger of his right hand ready for action. The young women gave 


\section{A Sportsman}

him a wide berth, but the elderly matrons indicated rare courage.

The gaining of the gold medal for Colorado had become known in Colorado soon after its award, and created a vast deal more of enthusiasm than it would have elsewhere, from a region which had experienced more or less a feeling of isolation. The coming of the commissioner from the French government and of the other distinguished visitors was heralded by telegraph in advance, and we were surprised, when within ten miles out from Denver, to be met by a committee of mounted citizens that had been formed to escort us over the last part of our route, and to learn that a rousing ovation was to be tendered us upon our arrival.

As our stage drove up to deliver us at the Planters' Hotel, a large portion of the town was in evidence, besides a band of music which discoursed lively airs. The greeting was most hearty and the hand-shaking my associates received was a new feature in their experience. It had been arranged that a reception should be given that evening in one of the church buildings, where we proceeded after a wash-up and change of apparel. The building, though not limited in extent, was crowded to its capacity, and to meet the expectations, Simonin, Heine, and I had to make acknowledgments of appreciation and references to some matters we knew of, and others we did not.

Mr. Geise speedily returned home, leaving Simonin and Heine and myself to bear the brunt of the ovations which were extended to us from the principal mining sections of the region. We made an extended examination of the mineral conditions, receiving banquets at Denver, Central City, and Georgetown, at each of 
which towns we gave lectures to meet the general desire of the people. Simonin's was on mining affairs and the comparison of Colorado mines with those of other countries. Heine's was upon the general world in comparison with Colorado, and the necessity of inviting experienced miners from European countries, especially from Germany. My lectures were upon the Paris Exposition and the future of Colorado, and I will here note that after the first delivery of my lecture in Denver I remarked to Simonin and Heine that I felt a consciousness that I had gone too far in my sanguine illustrations of the future of that country, and in my suggestions of the readiness they should be in to receive the benefits of the civilizing effects of railroads, which would ramify, and the developments that would occur from a rapidly increasing population.

It appeared to me that perhaps I was drawing too heavily upon the expectation for the nourishment of a moderate population, suffering from the want of many necessities of comfort, and largely isolated from the general world. But as I reflect now after an interval of forty years and consider the present population of the State, which has more than doubled in each decade, and the railroads which intersect its limits, surpassing in extent and profitable business any other similar area west of the Missouri River, and its annual yield of precious ores, exceeding that of any other State in the Union or of any European sovereignty, I am satisfied that my prophecies were more below than above the realizations. 
$A$ PROPOS of the Emperor Napoleon's interest in that the Emperor, always a dreamer of the Empire, had but lately experienced the reverses of the French troops sent to Mexico to aid the unfortunate Maximilian, brother of the Emperor of Austria, whom Napoleon endeavored to establish upon the throne of Mexico, and establish a Latin Monarchy there. Although Maximilian had been executed by the Mexican General Juarez and the French troops had been withdrawn, the Emperor, with that tenacity constitutional with him, had never become reconciled to the result, and undoubtedly still dreamed of a future conquest. It will be noted that Napoleon in his scheme of a Latin Empire upon the American continent had more foundation for a possibility of success than would be willingly conceded by the younger generation of this country, whose memories do not extend back forty years, and who do not remember how critical at many times the conditions were during the Civil War, when the strongest supporters of the Union grew faint with apprehensions. There were several occasions when, if a recognition of the Southern Confederacy by the principal European countries had occurred, it would have almost insured the success of the South.

There is but little doubt that when Napoleon, supporting Maximilian during the earlier part of the Civil War, when the Union was distracted by its internal convulsions, invited the English government to join France in a recognition of the Southern Confederacy, the Union was in great peril, for a recognition, as proposed, would have involved the North 
in an additional conflict with the most important European nations. Palmerston, then Minister of the Exchequer, was well known as friendly to the South, and even Gladstone publicly expressed himself as believing that the Disunionists would prevail. Roebuck and Laird and many others in the English Parliament were savagely opposed to a continuance of the American Union, and we owe much, if not immeasurably, to our American Minister, Charles Francis Adams, for his courageous and manly defence of the Union, and his defiant challenge to war with the English nation, without delay, upon its recognition of the South. To John Bright more than to another in the English Parliament in his vigorous defence of the Union, and largely, undoubtedly, to the heart-felt influence of the British Queen, do we owe much for the preservation of our now glorious Union.

It is a question yet to be answered if Napoleon had not made an understanding with the leaders of the Southern Confederacy for aid in establishing a Latin Monarchy in Mexico, in case of the recognition and success of the South. He, however, did not dare alone to brave the contest, or to involve France in a war which could not be responded to by its people, already imbued by a republican spirit. Nor could England involve herself when the support of her people would not be given for a war in which their sympathies could not be enlisted, despite the antagonism of the autocratic classes-who to a unit viewed with jealousy the growing importance of America,-now happily averted by an overwhelming power, which cannot be diverted. 
Times have changed since the time of George the Fourth and Lord North, when representatives of rotten burroughs and kingly idiocy could declare war against the wish of the people, when foreign mercenaries could be hired to conquer freedom. And the greatest rebellion of history was overcome.

Patrick Henry said in the Virginia Assembly: "Three millions of people armed in the holy cause of Liberty are invulnerable to any foe the enemy can send against us."

Yet, in the Civil War a vast number larger were engaged for independence from the Union. Yet the liberty they fought for was not obtained, but occurred in the freedom of millions of slaves. Happily, dissension was averted, and now will go forward clearly, absolutely, and distinctly the Americanizing of the world.

Mention has heretofore been made of the Union Pacific Railroad, which was proceeding with great rapidity, and more so than any railroad ever before built, accomplishing in one day during its building across the plains the laying of ten miles of rails, and the completion of the railroad in its connection with the Central Pacific Railroad from California was made at Promontory, beyond Ogden, in I869.

I have no doubt but Jay Gould acquired over twenty-five millions of dollars first and last from the Union Pacific Railroad, largely increasing his fortune at the expense of the road, and from his actions the road was mainly thrown into the hands of a public receiver. He was not interested in the first building of the road, but its condition afterwards presented a grand object for his peculiar manipulations, which 
appearing at first so fair and promising led to confidence in his management and largely influenced its consequent bankruptcy; from this it was only rescued by the drastic efforts of a new management. From the hands of the receiver it emerged in good form, and has now become, with its outreaching auxiliaries, one of the most important, extensive, and profitable roads in this country. As I was somewhat familiar with the artful methods of the crafty Gould, which were well known, though not to the public, in some particulars in connection with the Union Pacific Railroad, I will diverge here in references, especially to the latter.

After the completion of the road, the general business of the country being dull, it was not profitable, and there were periods of depression when the burden of the managers was heavy. The through business was limited. Land sales were slow and expenses were heavy. Land bonds had to be issued predicated upon future realizations, as well as income bonds to be paid by future profits. It was during one of these periods when the heaviest owners in the road, loaded up with securities which were difficult to sell or borrow upon, invited the aid of Mr. Gould. This was declined. The burdens became still heavier, and some of the largest owners refused to further sustain a sinking credit in defence of their own holdings. But Mr. Oakes Ames, and a very few others who believed in the ultimate success of the road, held on with unabated confidence, with credit, however, much impaired.

In this extremity, when again being solicited, $\mathrm{Mr}$. Gould signified his willingness to come on to Boston and confer with the bodyguard. The meeting ex- 
tended over several days in the Sears Building, where the offices of the company then were. The road was then behind, with a large floating debt. The conference resulted finally in a transfer of large blocks of stock at about fourteen dollars per share to Mr. Gould from the principal owners, besides large amounts of land and income bonds at large discount, and a loan was arranged by Mr. Gould of ten millions of dollars to take up the floating debts. When the trade was completed and the stock and bonds were delivered and the checks in payment, Mr. Gould drew from his pocket a thickish, good-sized memorandum book and asid:

"Gentlemen, I will draw your attention to this book. A year ago, when you first invited me to join you, I sent out an agent to Omaha, who, with assistants, spent a number of months in a critical examination of your road. In that examination every station on your line was visited, and in this book you will see a description of the stations, with the names of every station keeper, and an account, as correctly as could be obtained, of his history before and after joining your service. You will find here an account of his conduct since acting in your employ. If he is of temperate habits and honest: if he is a gambler or negligent, or identified in any way with suspicious or doubtful characters; also an account of the local resources about each station. In fact, a description in detail of the actual situation of your road, and the character of the lands acquired by the government appropriation and their possibilities. All this information has been acquired by my agents, who in assumed characters of traders, land buyers, 
sportsmen, and otherwise have studiously obtained the information. I required this before undertaking so large a venture as I have now made with you, and I wish to assure you of my belief that you have an immensely valuable property, and that I believe the period is not far distant when you will commence dividends, which will be fairly earned by the legitimate business which will come to you. I will say that I shall not dispose of any of my stock until it will sell at above par, and be on a dividend-paying basis."

And he did not. Business increased steadily. Mr. Gould became a director in the company. Having a large amount of stock and bonds, he influenced the directors to commence paying dividends before such should have been paid out, and fifteen millions of dollars were so paid, which should have been retained as an appropriate surplus for so large a company. But it was Mr. Gould's interest to have these dividends paid to enhance the market value of his stock and securities, and it is probable that it did not require very much urging to have the directors acquiesce in it.

The occasion had now arrived for Mr. Gould to display his astute and complex system of self-improvement. Mr. Oakes Ames was dead. Mr. Gould resigned as a director, and Mr. Sidney Dillon was made president. Affairs looked well and dividends were paid regularly. The president was always friendly with Mr. Gould, and when he died he possessed a very much larger property than he was credited to have possessed. It was prudent for Mr. Gould to resign as a director in view of the rôle he had assumed of benefactor of the road in giving buoyancy to the financial statements and bridging over dividend-paying periods, when little 


\section{A Sportsman}

anxiety existed with the management regarding the source of supply.

With the growing importance of the great national highway, it should control and own a considerable number of independent branch roads which had grown into existence as feeders along the route, and the benevolent and philanthropic Mr. Gould, anticipating such a demand, commenced the acquirement of such roads, which were duly turned over to the Union Pacific, which was relieved from the tedious and somewhat perplexing details of purchasing, by presenting them in lump sums quite desirable to accept in view of their value.

I met one day at the Windsor Hotel, in New York, ex-Governor Evans, who expressed his elation in having just disposed of the Denver and South Park Railroad in Colorado, to Mr. Gould, and he exhibited to me the good-sized certified check of Mr. Gould for the sum of twenty-four hundred thousand dollars, just received for the sale. This railroad being soon afterwards acquired by the Union Pacific road, I had the curiosity to ascertain what was paid for it, and learned that it was thirty-six hundred thousand dollars, a small matter of twelve hundred thousand dollars difference. This road was afterwards completely abandoned by the Union Pacific as worthless and not worth keeping against its bonded indebtedness, being a long out-ofthe-way road to Leadville, superseded by shorter and more efficient roads.

Other roads followed in sequence by the beneficent aid of Mr. Gould, and finally the Union Pacific, with a depleted treasury, suspended its dividends. Ere this period arrived Mr. Gould, having a necessity for 
funds required in another direction, disposed of his stock and Union Pacific securities, and as the stock toppled from its high price of one hundred and thirty and raced down toward zero, sold borrowed stock to an alarming degree. In this, however, he was fortunate enough to save himself from loss by re-buying at low prices which enabled him to make good deliveries to the accommodating lenders.

In the later sales of roads to the Union Pacific Mr. Gould had more difficulty in having them accepted than in the earlier sales, owing to an awakened feeling upon the part of the Union Pacific directors, as they viewed the depletion of their treasury, that they were approaching the situation of the cats who appealed to the monkey in the distribution of the cheese, who, scaling the weight, constantly bit off mouthfuls to equalize, until the whole disappeared. Then Mr. Gould, indignant at the lack of appreciation of his advanced intuitiveness in knowing better than they what they needed, assumed the rôle of an injured friend, whose necessities would require him to appear in self-defence as an opponent of their road, and perhaps oppose the management of the road so unfortunately acquired, which would perhaps require a connection with a new road to be built, which might to some extent parallel their own. This Gould was a great bluffer, and one effort in this line was the loading up of the Union Pacific with the Kansas Pacific road, which, with his sympathetic friend, Russell Sage, he had acquired for the benefit of the former. The Kansas Pacific went very hard, but by dint of pleading, urging, and threats, came in. But when the Union Pacific Railroad went into the hands of a receiver 


\section{A. Sportsman}

those cold-hearted managers, insensible to the blandishments of Mr. Gould, and the record of his devoted services to the road, had the ingratitude, claiming under the shelter of the law, to prosecute the friendly Gould and the guileless Sage for the recovery of seven millions of dollars fraudulently gained, but which was never recovered.

Mr. Gould received his important start in financial life from his association with James Fisk, Jr., whose remarkable combination of audacity, buffoonery, roguery, daring, and unscrupulousness after he had stolen the management of the Erie Railroad from his patron, the veteran Daniel Drew, commended him to Mr. Gould. Fisk, after the execution of his gigantic fratd and perfidious robbery of the Erie directory from the confiding Drew, required the peculiar talents which Gould possessed. The glaring, shameless, and ridiculous act of one like Fisk, without personal means, striding as he did into the control of an extensive railroad, obtained by the fraudulent use of voting proxies obtained with the money of Daniel Drew, paralyzed the street and outraged all sense of law and order.

A recitation of the means employed is unnecessary here, and has been sufficiently ventilated. Gould, with all his craftiness and daring, would never have attempted the assassination of rights which Fisk did. But he could, with a master hand, loot the dazzling wealth displayed and hold the mock Duke on his stolen throne. This he did long enough to stuff his pockets full. Then, with gracious confession of wrong, he made restitution of settings from which the gems were stripped, retaining the values, and in 
extremity fled before the old Commodore Vanderbilt.

I knew both Fisk and Gould somewhat well, and many a cigar I have smoked with Fisk before he became notorious, when he was an employee in Boston with a mercantile firm, of which he afterwards became a member but was dropped for his conspicuous forwardness. Not now, for I have diverged too long, but later on I may relate an incident of peculiar interest in the life of Mr. Gould not known, when he more than found his match in C. P. Huntington, his superior in patience and astuteness. In this case Gould held the superior hand, but threw it down in complete surrender. This after a three days' interview in St. Louis.

$\mathrm{O}^{\mathrm{F}}$ the future of Colorado one may be well assured with its agricultural values exceeding its minerals; its inexhaustible mines, which have already yielded a billion of dollars; with its coal deposits equalling those of any other State, though not yet producing one tenth of the product of Pennsylvania; and its facilities for sustaining more than twenty times the present population. Can one doubt the future? What shall be said of very many more areas of similar value in the Union? What is to be the future of the great American Republic? What will be the result of many hundreds of millions, as comparatively soon there are to be on the North American continent?

There can be no retrogression. The phantom of the Yellow Peril unfurled by the Muscovite to enlist sympathy for his aggressiveness in the East, which has met with disaster, fails to alarm the American people. 
The advance of the Japanese in intelligence and comprehensiveness does not exhibit any weakness, and will have an important effect on the Celestial Empire, which, however slow in progress, will inevitably advance. It is impossible to estimate correctly the results of the Eastern war, which may be of far more worldly importance than now estimated, and may ultimately change the conditions of some European nations, and possibly affect our own.

Upon Prof. Simonin's return to Europe he published a series of letters upon Colorado, which had extensive circulation in the Revue des Deux Mondes. One incident by him mentioned reminds me of a dinner given us in Denver before his departure, composed of a dozen or fifteen, in which I appeared in his account, incorrectly, as an affluent miner, who distributed gold nuggets for dessert. This was a mistake, the facts being that I, having purchased half a saucer full of moderate-sized gold nuggets for a few hundred dollars, exhibited them at the termination of the repast, while we were conversing over our cigars. Occupied in conversation, I did not observe the stupid waiter had taken the saucer around the table, with an intimation for self-helping, and before I discovered this feature, the circuit of the table had about been made, and each diner had taken a selection and were making appreciative comments. It was too late to make a correction without an awkwardness, and so I let it pass. I did, however, feel like poking the ribs of a fat man opposite, who, instead of taking a small nugget as the others did, appropriated a full ounce specimen worth at least twenty dollars, with the remark that he should give it to his wife as a souvenir. This was very 
pleasant for his social advantage, and gave me a lasting souvenir of his memory.

I have never had any political aspirations, and never held any public official position except that given me by the United States Secretary of State, William H. Seward, in 1867 , as commissioner to represent Colorado that year at the World's Exposition at Paris. Though several opportunities in my life have occurred when I could have gained without much exertion some official positions, I have given them no attention, as I have observed that once engaged in political affairs one is apt to be led on and become involved in the consequent following, often to experience many perplexities and disappointments, as instanced in the cases of so many, as I have witnessed.

I have not declined such from possible interference with business pursuits-as I have always made such a secondary matter-but mainly from a fear that in politics I should lose largely my independence, and probably my ability to prosecute those out-of-door pursuits toward which I am so inclined. I often think, however, when I witness the exertions made by those politically inclined for official positions, of the opportunity which offered itself to me in Colorado for obtaining a prominent political position which seemed of easy conquest. At that time Congress had passed, as an apparently political necessity, an enabling act by which the Territories of Colorado and Nevada could be admitted into the Union and send their senators and representatives. The population of the two Territories was limited and insufficient under the existing law for either of the two to gain Statehood. But Congress passed a special enabling act 
with the expectancy of gaining new senators and representatives, and it was put to vote in both Territories. Nevada voted for and accepted admission, while Colorado declined.

At the time I was in Colorado, the subject was under consideration and there were several congressional aspirants strongly favoring the admission of the Territory, who were not particularly popular with the people. I had never given any expression of my political tendencies, and was much surprised to find myself referred to as a probable United States senator in case of Colorado's admission, and was called upon by the representatives of both the Republican and Democratic parties. First by old Commodore Decatur, so-called, the leader in Republican circles, and some of his friends, with whom I had an extended conference, and from whom I had a tender of the nomination by the party for United States senator for election by the new State representatives, which would come in upon an affirmative vote of the people for admission. A moderate amount of money would be required for the expenses of canvassing and elections. I gave the parties respectful consideration, but most positively declined the proposed honor, as I had no political aspirations whatever, and in no way could I accept any political position.

It was rather difficult to satisfy my visitors of the sincerity of my conclusions. They left me after the evening's conference with the expressed opinion that I might perhaps change my views after more consideration. The following day I was called upon by the prominent Republican politician who expected, in case of the admission of Colorado, to be my Sena- 
torial confrere, who made strenuous exertions for me to change my views and accept the nomination, which he was entirely confident would cause the admission of the Territory to Statehood, and assuredly occasion our election. But I was entirely firm in my resolution, and have never had any occasion to regret it.

When the election came the acceptance by the people of the opportunity for admission was declined by a very small majority, so small that it could easily have been overcome by a very moderate effort, and Colorado would have become a State several years earlier than it did.

While Nevada to this day has but very slightly increased its population from about sixty thousand, existing at the time of its admission as a State, Colorado has nearly twenty times the population it had in 1867 , and is increasing in all respects in a remarkable manner.

My stay in Paris while Commissioner from Colorado was one I shall always remember as of exceptional interest; and, although I have been there a number of times since, I have never found it so attractive as it seemed to me during the great fair, when it was thronged with so many visitors from all parts of the world, and especially by so many Americans whom I became acquainted with. Lately I visited the great World's Fair at St. Louis with a party of friends, and in expenditure and extensiveness it surpasses any before given. When I was there, however, in June last, it was still in a considerable state of unpreparedness, but I found it of great interest. The attractions were many and of peculiar attractive- 
ness. The area occupied, being very extensive, required a good deal of walking to reach the various departments. It is easy to criticise, and I do not propose to do so relative to the general exhibit, which undoubtedly exceeds any other ever given in many respects; but, having seen quite a number of world's fairs, I am more impressed than ever with the plan followed in 1867 in Paris, of having a large oval building-which in that case was about a mile and a half in circumference, built of iron and glass, which contained the principal exhibits of all nations-so that one could pass continuously from one nationality to another in rotation, upon the class of exhibits one wished to follow, without the necessity of traversing long intervening spaces, over roads and pathways, saving loss of time and fatigue. The machinery and heavy wares could then be relegated to appropriate annexes, where they could be seen by those specially interested in such, which do not appeal to all visitors.

The array of beautiful buildings of perfect outline at the St. Louis Fair were of striking architectural perfection, and occasion regret to think they were all demolished at the end of the fair.

At a dinner which I attended, given in London by Mr. Robert Bowles, an American banker, to Henry M. Stanley, the African explorer, upon his return after finding Dr. Livingstone, I was much interested during the evening's conversation by Mr. Stanley's references to his explorations, which indicated his remarkable character as one of indomitable determination and courage. He remarked to me if I remembered of ever having met him before, to which I answered in the negative; to which he said that we met in Central 
City, Colorado, in I867, when hereported for the Miners' Register, a paper of that town, my lecture on the Paris Exposition, and obtained from me some notes concerning it. This had entirely escaped my memory until he reminded me of it, and though $I$ had no recollection of his name I remembered the incident. My name, then of slight local import, was in contrast with his name, unknown to the world-prominence it was soon to 'attain.

Stanley was one of those explorers who was exceptional among those of his class, in realizing a large fortune, in contrast with Mungo Park, Dr. Livingstone, Du Chaillu, and others who were prominent in their explorations of the Dark Continent. As a lecturer he was not a prominent success, but his efforts in Africa led to a complete revolution in the affairs of that continent, and a parcelling out of its districts among the European nations, and a farreaching result, comparable with that of the American continent from the discovery of Christopher Columbus.

In one of my many trips to London I met my old friend Samuel Ward, known so well among his friends in England as "Uncle Sam," the brother of Mrs. Julia Ward Howe, and the uncle of Marion Crawford, the novelist. Mr. Ward was prominent in his own country some years ago for his literary articles, and as the author of a book of pleasant poems, and particularly as a bon vivant, and the recipes of his dishes and punches are still in vogue. As a lobbyist in Washington he was at one time the most influential in directing the policy of measures in Congress, which are even now more directed at times by outside influences than would indicate the spontaneity of our representatives. 
Probably no American in private life was more popular or better known in London than "Uncle Sam," and I have spent many pleasant hours with him in his apartments on Piccadilly, furnished and left by the Duke of Portland before he inherited his present rank. The attachment of Portland for "Uncle Sam" was only exceeded by the affectionate regard of Lord Rosebery, who would monopolize, as far as he could, the association of "Uncle Sam" with himself, and who had in his several residences in country and town, apartments specially designated with the name of Samuel Ward.

"Here," said "Uncle Sam," pointing to his writing table one day, "is where Marion Crawford wrote his first book, of $M r$. Isaacs. He had told me about his experiences in India, and I was very much interested in his account of the character he met represented in his book of Mr. Isaacs, and I suggested to him that he should write a book about him, and that he should commence now; whereupon he sat himself down at the table and started in, and became so much interested in his work that he never quit excepting to eat and sleep and take a little exercise, and in about a week completed it and sent it to print."

One driving with "Uncle Sam" at the fashionable hour in Hyde Park would readily perceive the unlimited attentions he would receive, and the apparent rivalry existing for recognition from this placid gentleman of attractive presence. One night I was with him in a stage box at Drury Lane Theatre, which theatre he remarked he had not visited for many years, since he was a young lad pursuing a line 
of study in London, and we came to witness a spectacular play called America. Before long after the commencement the Prince of Wales came in with a party of men, occupying the royal box opposite. Soon an equerry of the Prince came over and requested the company of $\mathrm{Mr}$. Ward in the royal box. When he returned some time after, I asked him if there was anything unusual, which he answered smiling, saying, nothing in particular, excepting that the Prince had a garden party coming off the following afternoon at Marlborough House, to which he had asked some American visitors, among whom was a charming young Miss C., to whom he asked of Mr. Ward to give some attention.

Poor "Uncle Sam" died a few years after on the Mediterranean, on his way back from Italy, where he had gone to visit his sister.

When I last left him he was writing his reminiscences, which probably he never completed. These would be of great interest, and possibly may have been completed, and may appear at some later period.

IN London-and I am referring to the old city limits and not the expanse included in the new growth of surprising extent-there are several associations of ancient date known as guilds, survivors of former useful purposes in promoting the interests of certain trades, known as the tailors, bakers, skinners, fish mongers, brewers, etc., the skinners being those who dealt in hides.

These originally were of modest pretensions, designed to protect by mutual support particular trades. 
These purposes have passed away by the extended growth of the city and its surroundings, but the city charters of the associations are still in existence, while the trade members gradually fell out by deaths, and others foreign to the various trades were elected in place, so that in reality none of the trades are represented in membership, and one going to the dinners of the tailors or the bakers would look in vain for any one who had ever cut a coat or baked a loaf.

The present members of the guilds are a jolly lot of convivial souls, who elect their successors from among their friends, prominent business or professional city men, who in turn continue to elect a similar class. The basic bond of union is the large fund existing to the credit of the guild, which in some instances is very large, as in the instance of the Tailors' Guild, amounting to over a million pounds sterling, aggregated by many years' increase of values from city property holdings. The annual incomes, therefore, of some of the guilds are very large, requiring considerable ingenuity upon the part of the managers in the methods to be pursued in dispensing the funds for the most complete satisfaction of the members.

A considerable fondness is indicated for monthly banquets and weekly lunch meetings of committees to consider important subjects affecting the interests of the Guilds, which many presume to be concerning the character of the wines to be put in cellar in place of those which have been retired at previous meetings, and as to the details of the succeeding banquets. The banquets are of the most elaborate and expensive character, at least those of the tailors and bakers. These I have frequently attended, by invitation of members, as 
members have the privilege of inviting a friend or two to the monthly banquets, but not to the weekly lunch committee meetings, where the business is too serious to admit of intrusion, as may be well understood in riew of the difficulty which exists among the opulent guilds in disposing of sufficient funds to equal the income. In vain are the markets sought over for the most expensive viands. Fruitless are the efforts to swell the cost amount equal to the sum appropriated. Clear green turtle soup from Birch's or the Ship and Turtle at four shillings a plate, with squares of green turtle fat as large as a fat man's two thumbs, are a bagatelle. Johnny Dorees from the North Sea, at seven shillings a pound, help some. Sole slips and spring lambs are of slight value, but helped on by Delaware canvas-backs, golden pheasants, and Norway woodcocks. A confusion of sweets count something. The Hungarian band is an element of value. Sims Reeves, the vocalist, and other eminent artists, at from fifty to a hundred pounds each, to appear between courses when the dinner is well on, cannot be overlooked, but still a fainting hiatus of apprehensiveness creeps on when the summing-up still shows a surplus. A happy thought, as a glimmer of sunshine in a dark day, flashes in. The box of chocolates and a silver pencil given each guest at the last banquet may be given over for a sixteen-bladed pearl-handled jack-knife, with a corkscrew attachment from Sheffield, which will just bridge over the difficulty.

A suggestive mind, that of Alderman Brown, who will sometime be Lord Mayor if he lives, as all City aldermen become Lord Mayors in rotation, if they are wealthy enough to stand it, and if not, fall out for a succeeding one. An adjournment will now take 


\section{A Sportsman}

place, after a few bottles of old port of the comet year from our own cellar.

The wine cellars of the guilds are something important, and to refer to with admiration as containing the choicest liquors and wines to be obtained, and a lay-down of new stock occurs as fast as any old stock is drawn upon, and any member or guest at the banquets may freely call without limit for the most select wines on the menu. All goes merrily, and the banquet draws on.

The Worthy Warden, arrayed in his gown of ceremony, adorned with chain and medal of insignia, leads on, preceded by ushers with staffs, and the diners follow in proper order to the tables, garnished with flowers and precious silverware accumulated in past years. Nearly all express their preference for the clear green turtle soup with slabs of turtle fat, a specialty of renown with the guilds; and express not too much hilarity at this moment, in memory of the incident illustrated in an old number of Punch, where an aldermanic epicure, with portly nose, and napkin under chin tucked, turns sadly with repressed severity upon his adjoining companion with the request that he will refrain from further jokes for a while, as he had already swallowed two morsels of green fat without tasting.

Will have Chambertin of 1867 or Clos Vogeout of ' 88 ? No, thanks, shall take Scotch and soda, but suggest you try the old port of the comet year of 1872 . Money can't buy it.

Hark! the alcove curtain parts, and a song from the lovely lass of the Highlands.

Later on, the loving cup of gallon dimension and double handled goes around, but with no interruption 
of the feast. The one beside you, rising in place, turns away from you toward the one beyond him, receiving the cup, from which he sips and turns facing you smoothing over the cup edge with his napkin; you, standing, receive it and drink from, and in the same manner pass it on to your neighbor. The time has arrived for coffee and cigars, and the regular toasts are given in order:

To Her Majesty the Queen.

To the Army.

To the Navy.

To distinguished guests.

To foreign visitors.

To municipal magnates and others.

It was on one of these occasions in Jubilee year that I was pulled into an anxious box, so suddenly and unexpectedly that I made a very awkward appearance. The one who was to respond to the toast of foreign visitors was unaccountably absent, and a pause occurred until the fact was evinced. The Worthy Warden, whose guest I was, and whom I had supposed a friend of mine, abruptly announced in calling my name that I would respond to the toast in the absence of the first party. It was a staggering blow, for which I was in no way prepared, and if I had received any intimation of it, I was hardly in the condition for a mental exertion; for an early lunch and a delayed dinner had given an edge to my appetite difficult to hold, and I had eaten far more than was my usual habit and, al. though moderately abstemious in drinking, some misguided friends about me, with mistaken hospitality, had taken advantage of my obliging disposition to ply me with various creations of which I had been ignorant 


\section{A Sportsman}

before. It was clear to my own consciousness that I was better fitted to grace a cannibal barbecue than to give entertainment to intelligent beings from whom appetite had flown.

Thinking of the advice given by one counsel to another, in the absence of favorable evidence to give a general denial of everything, I entered my protest at the assurance of the Worthy Warden in designating me as a foreigner and qualified as such to respond to the toast: Was I not at home among my own race, speaking the same language and thrilled with the same pride and enthusiasm which they all experienced in this Jubilee year in the reigning of the most amiable and lovable and wise sovereign that ever graced a throne?

Did not my heart swell with the emotions kindred to their own in contemplation of their magnificent army and navy, and the advance of civilization the world over upon the approach of their unifying force power?

Did I not find a sympathetic and hearty welcome here, and a hospitable greeting which no one can so fully experience and enjoy as he who returns after a long absence to his old home?

Time, with its unstaying hand, will take away those living at the time of departure, but are not their descendants of the same blood and thought and feeling? and when I look around upon your faces here, and note the kind expression of eye and countenance, I am tempted to believe that you may accept me as one of you, though I have been away for two centuries and a half.

It was long ago when my English ancestors 
departed from these shores for the distant land of America, where in New England for seven generations, with intermarriage with their own class, they lived on, and I am, so far as I know, of the first to return home again. I was not consulted as to the place of my birth, and if I had been I was too young to have had voice; and what mattered it, if by your acquiescence I have not lost my birthright, and you do not deprive me of the memories which cluster about the land of my origin?

A few centuries ago your ancestors and mine fought out together for the great rights of liberty in advance of the world and established the bulwark of civilization, and to them mutually belonged the renown of our illustrious men whose bones are interred in your sacred temples of sepulture.

You will not deny from me a share of the loyalty you all feel, or the wholesome pride and emotion you experience when passing through the immuring walls of the Abbey, or contemplating on the shore of the Avon the resting-place of the remains of the gentle bard whose imprint on the face of time is everlasting.

Great and glorious is the record of your race, and the illustrations of progress given by your ancestors in the expanse of other climes. It is, however, but the exemplification of the sturdy, inborn merit inherited from the motherland. Not too far away are they from their old home to be reached by the friendly hand of recognition, though rolling seas intervene, nor can they be stayed in their courage and indomitable energy and intelligent perceptiveness until the whole world shall yield to their progress and accept the domination of our mother tongue.

Then, when one shall come again as I have from 
a distant part, descended from your own, returning to mingle among those whose sympathies and affections and pride are as of his own, and may, upon an occasion similar to this, be given the honor of being called as the representative of a foreign element, may you not say, "Not so; he is our kinsman?"

CEORGE GROSSMITH, an actor of considerable I celebrity in England and of some in this country, was at one time playing an engagement at the Savoy Theatre in Gilbert \& Sullivan's play The Yeomen of the Guard, and had appeared in the first plays, and on in succession in important parts of the plays of the mentioned composers, and with remarkable success, and from which the authors had gained much advantage. He was of slight form, and, although not particularly gifted in voice, was very correct and clever in acting, and withal of modest demeanor and sterling qualities. He was also an author, and in extemporaneous musical composition and song, a great favorite. With my wife I attended the play of the Yeomen of the Guard, in which Grossmith appeared as Jack, a halfbrained wandering street minstrel, accompanied by Geraldine Ulmer, a Charlestown (Mass.) girl of the same class. Their wandering about with songs and dances added much to the entertainment, and I followed them with more interest than given to any other party. Jack, in love with his companion, is finally thrown over by her for one more to her liking, and falls over in the end, dispirited and crushed.

Some days after, my wife and I were invited to dine with some friends who had tickets for the theatre, and 
the play to which we were invited was the Yeomen of the Guard, and on the second time I was more interested in Grossmith's acting than before. A week or two after we were again invited to a dinner with theatre after, and to our surprise the play was again the Yeomen of the Gurad. I was more pleased than ever with Grossmith's faithful rendering, and after reaching home at the hotel we were staying at, I said to my wife, "Was not that acting fine of Grossmith?" in which she agreed, and I sat down, upon the impulse, and wrote him a letter expressing my admiration. This, as I can remember, was something as follows:

\section{Dear Mr. Grossmith:}

By singular coincidence of events, I have witnessed three times with my wife your faithful acting in the Yeoman of the Guard; and, while I am not partial to witnessing a repetition of plays I have freshly seen before, I will confess to you that I am sure I have experienced more satisfaction from seeing your second and third appearance, than from the first. It is easy to play the fool when the character is a natural gift, but when a man of sense plays the fool as well as you do, it has called for a wit and cleverness which I admire, and I express it. I am a stranger to you, and you may not care for this, but you cannot deny me the satisfaction I give myself in writing you as I do, and let it pass.

Very truly yours,

I went to the seashore the following day for a week, and the matter passed from my mind. Upon my return to my hotel I found among some letters waiting my return one from Mr. Grossmith, saying:

\section{DEAR SiR:}

But I do care for your letter, more perhaps than you can believe, for I received it at a moment when I was unusually 


\section{A Sportsman}

depressed from an incident which had occurred, and I carried it to my wife and said: "Is this not fine? it encourages me" I thank you from my heart, and remain

Sincerely yours,

George Grossmith.

Some weeks afterwards my wife and I were invited to dine in Portland Place, by some English intimate friends of ours, and at dinner we were told that our entertainers were to give at midnight a musical party, which would be attended by about a hundred friends, among whom would be several artists of note, and $\mathrm{Mr}$. George Grossmith was mentioned as one. I was very much amused at the prospect of meeting Mr. Grossmith in this manner, and told my amiable hostess of the incidental correspondence I had with him, and she said she had known him for years, would present me to him upon his arrival, and it would be interesting and amusing. This she did, introducing my wife also. During the following amusements, Mr. Grossmith improvised a song with piano accompaniment, in which he went over our affair, with so many ludicrous interpolations, in which I appeared as a North American Indian, that we screamed with laughter, and one young lady was so amused that we had to rest for a while upon her approach to a hysterical condition.

I am reminded here of the elder Sothern, the actor whose part as Lord Dundreary was so amusing, who visited me at the lake with Holland the actor and two other friends, perhaps twenty years ago. Sothern was a great joker, and put up a good many, but was rather sensitive when they were put on him. He wrote a very amusing book, entitled Birds of a Feather Flock Together. One day Holland said to me: 
"Snr hasothe a new cravat pin which he thinks unique in this country, sent to him from England, of silver and gold, showing a fishing rod and line and a creel. But I have also one sent to me which Sothern does not know of, and although he is not wearing his just now, he had a great deal to say to us about it, and is very much set up over it. You take this pin and stick it on, and we will hear what Sothern has to say about it."

I did so, coming in to lunch with the pin, which soon caught Sothern's eye, and with astonishment he asked me where I had obtained it, to which I answered, carelessly:

"Yes, a rather pretty pin. I bought it at one of the country towns as I came up to camp."

"Good heavens," said Sothern, "what did you give for it?"

"Well," I answered, "I bought a dozen of them at four dollars, they seemed so cheap. I thought they would make very good presents to the guides, as they are awfully fond of anything of that kind."

I relate the following two instances indicating the push of two American girls who came within my personal observation, and although not coming within the lines of sporting reminiscences, may be of interest. These incidents being of a personal character will be considered confidential by the reader, who, I assume, will not mention it unless it may be to most intimate friends, whose reticence can be relied upon.

The commencement occurred in Boston before I had reached my majority. I had a clerk in my employ, a rather clever sort of fellow named Edwards, who occasionally referred to a flaxen beauty at the 


\section{A Sportsman}

cheap boarding-house where he lived, whom he accounted to be a most extraordinary beauty of much spirit and wit, and who he predicted would yet have some prominence in the world-the lovely Miss Jane Dare (an assumed name), the daughter of the widowed landlady, who made vests for a clothing house at the munificent sum of two or three dollars a week. Her father had been at one time a well-to-do merchant, who conducted a line of sailing vessels to some foreign port, but left his wife and only child penniless. It may be assumed that the subject was one of no particular interest to me, but from frequent mention of the excellent qualities of Miss Dare my curiosity was aroused, and I finally said to Edwards, "Invite me down to supper some night, so I can view this prodigy of exaltation," little imagining that I should become a feature in the future career of this sprightly Jane Dare.

How casual and slight are the circumstances affecting the lives and destinies of mortals. Accordingly, as a lamb to the shambles, I accompanied Edwards down one evening to the dingy brick structure, on a side street, where he obtained his fried chops and lodgings for three dollars and a half a week, and where the rosycheeked Jane dispensed hot biscuits and doubtful jam to half a dozen embryotic merchants of Edwards's type. The butter was strong and the tea was weak, and the muffins of uncertain stability; but Jane, Jane, Jane! she was as radiant as a butterfly's wing and looked as sweet as an apple blossom; of medium stout build, fair complexion, blue eye and golden hair. She gave me a hearty welcome as the friend of Edwards, and I scarcely regarded her excepting what I could take in at a glance, as I observed the somewhat suspicious 
aspect of Mother Dare, who evidently viewed me with some curiosity and possible apprehensions. Quite needless in my case, and it was not until my second call, on a following evening, that I ventured to intimate the necessity of replenishing my apparel by the addition of a waistcoat-after an hour's conversation with the mother and daughter and Edwards about the needed improvements in tenement houses, and of reform in the school system, and other serious subjects -and before I left I had my measure taken for a new vest by the tapering hands of rosy Jane, who held pins in her mouth. A third visit was required to fetch the material, and my growing fondness for the mother's tea, of which I could hardly get enough, evidently manufactured from the garden shrubbery, seemed to disperse any suspiciousness which might have existed.

I ventured to express the satisfaction which might be derived from a drive about the beautiful suburbs of the city. Mother Dare seemed to understand who should comprise the party, and expressed the difficulty of getting away on a week day, but might be arranged on a Sunday, when a pot of beans would answer for the evening meal. It was then suggested, as we were all to go, that a street car excursion to the Mount Auburn cemetery would answer our purpose and give us a cheerful recreation. So we went out the following Sunday afternoon to the cemetery, and I was struck by the simple and cheerful, but yet independent, ambition of the pretty Jane by her remark, as we viewed one of the most elaborate monuments there, that she would be about willing to die if she could have over her grave so beautiful a plinth as we had before us. It was very touching, and indicated the spirit of the 
warrior who sought the bubble reputation at the cannon's mouth. But Jane had no thought of dying, and I am quite sure she would not have expired to gain a hundred Egyptian pyramids.

A fair was to be held for charitable purposes in Music Hall a few evenings afterwards, and I had taken two tickets, and Mother Dare consented that I should take Jane there. I did, and Jane became elastic in spirit and rigged out in her best suit for the occasion. She was a lovely, charming girl, and no one could regard her costume in the glow of her beauty. When we entered the hall she was wild with delight and excitement at the brilliant costumes. "Oh, introduce me to some rich man," she said. "I must marry and travel to Rome and Paris and London. I have no time to lose. I must go." Jane was not particularly retiring or shy in disposition.

I saw approaching in the promenade an elderly, bald-headed, but well-wigged, confirmed and well-preserved old bachelor, whom we will call Ashberry, whom I knew, and who had lately retired from business with a large fortune after a wasted life at business, during which I doubt if he ever caught a trout. I mentioned the situation to Jane, who requested an introduction, and I accordingly presented Mr. Ashberry to her. Jane was a gusher of full volume, and the somewhat bewildered Ashberry, upon his quitting, asked Miss Dare if she would accept a lottery ticket he had just purchased in a probable two-hundred-dollar grand piano, put up at six hundred-six hundred tickets at one dollar each; would Miss Dare kindly accept the ticket? Would she! I had no doubt about it, and she did with a subdued, inexpressible gush which made Ashberry totter, and I 
felt sure he had then received an unusual wound. What fate depended upon that ticket? Pretty soon a number was hoisted over the piano, and Jane hastily looked over her ticket, and behold, it was her own! Her modest and limited sewing-room was not, perhaps, just suited for it, but she never thought of that. Where, oh, where was the precious man, the angel of light, the creator of her glorification, who had given her the ticket! He approached, without even remembering the number of his lucky ticket. But Jane quickly informed him, and showered upon him such a merry run of sweet words and tender glances that Ashberry fairly staggered in the mazy flood.

I thought it a good time to absent myself for awhile and, making an excuse to see a friend, left Jane and Ashberry for a promenade together, well satisfied that Jane would improve the opportunity. When I rejoined my May and December to accompany Jane to her maternal home, I found that the autumnal season of harvest had been woven in, and that Jane had acquiesced in the proposal of Ashberry to call upon her at her home. There, beneath the vigilant eye of mamma, it would be quite appropriate.

Time flew, as well as love, with galloping steeds, and expectation wreathed the way with flowers. My visits ceased and soon I learned of the engagement of Jane with her long-waiting, impatient Ashberry. The marriage soon followed, and Jane removed from her tearful mamma's humble abode to a mansion in a fashionable part of the city.

Years rolled on, a quarter of a century, and I had somewhat forgotten Jane in the busy hum of life, when one evening at a social entertainment in London I 
noted the steadfast gaze of a matronly and fashionably attired lady, who beckoned me to her side, but whom I failed to recognize, until with her hand extended she said, "Do you not remember me?" and then I saw it was Jane. I recognized then the abundant traces of her former beauty, not yet eclipsed by ravages of time: the still radiant cerulean eye, the yet unfaded golden hair, the expression of sprightliness, the soft, pleasant voice, which, when once possessed, never fails. It was Jane. She told me of the death of the lamented Ashberry; of her three children, one of whom, a daughter, was of surprising beauty and attractiveness and of whom I had heard repeated mention in connection with the bevy of fascinating American girls in London, little imagining she was the daughter of Jane. In fact, she was credited with having inspired a hopless passion in the heart of a royal prince.

And Jane had perfected herself in accomplishments in such surprising degree that she had become an element in London society, and I was surprised to hear of the exalted and exclusive class she moved in, and her familiarity with members of the royal family and her associates were of astonishment to me. This was the last time I ever saw Jane.

Another case of this character within my observation was that of her whom I will designate as Miss Frances Carroll, a young lady of remarkable beauty and character, who arose from a comparatively humble position to one of considerable prominence. She was the daughter of a retired and somewhat financially depressed merchant of Boston. Particularly fond of skating, I frequented in the season for such recreation the Back Bay area of the city, now filled in and built 
over by streets and rows of buildings. Here congregated on favorable days many young people for amusement, and many merry occasions we had there.

Among those frequently there was Miss Carroll, one of the most accomplished female skaters I ever saw, who elicited much admiration for her grace and agility, and whose attractiveness and buoyant manners brought many admirers. I was not long in making her acquaintance through some of my friends, one of whom was much smitten with her, but who made little progress in creating a reciprocal interest. Miss Carroll was not of the retiring cast, having a free and pleasant word for all her friends, and was in no wise backward in accepting presents of skates and various articles from her admirers, and I had the pleasure of presenting her with a pair of steel runners of recent improvement. Nature had endowed her with more than her skating accomplishment and beauty, as she had a voice of remarkable sweetness and power, and, as was afterwards shown, a remarkable faculty of application and mental ability, and with much ambition. She married soon a gentleman of wealth and removed to New York, where she became the mother of several children and occupied a prominent, though not generally accepted, position in society, and I attended several entertainments at her house there.

After seven or eight years' residence in New York she became estranged from her husband, occasioned, as reports go, from his improper treatment, and took up her abode in Paris with her children, occupying a prominent château on one of the principal boulevards, and I saw her there in 1867 . Her entertainments were conspicuous in American as well as French society, and 
her cultivated musical voice attracted particular admiration. After a few years in Paris she suddenly disappeared with her children for a few years, going I know not where, nor have I known any one who could tell. She returned to London where she has since resided, taking almost immediately a prominent position in that metropolis, which she has ever since sustained from her remarkable talents and accomplishments, and I venture to say that no American woman has ever attained more influence and prestige in London society, among the conservative classes, than she, and her identity will be easily recognized by those familiar with society in that city.

$M_{\text {the Prince of Wales-now King Edward the }}^{\text {ANY Americans considered it a privilege to meet }}$ Seventh - and it was my fortune to meet him on several occasions, and all who have met him will testify to his most admirable bearing and gentlemanly qualities, and he made all feel at ease in his presence by his pleasant manner.

Sir Walter Gilbey, most prominent and perhaps more so than any man in England in advancing the breeding of horses and their classifications, and in the organization of horses' societies, aided me most materially in England in 1883 in making a collection of Shire horses for shipment by steamer from London to New York, and from there in a special car to California, consisting of one two-year-old stallion and five fillies, all thoroughbred Shires, which had taken first prizes at the Shire horse exhibition in London, and which arrived safely in California, and from which during the years 
since I have bred their progeny. This breed of horses, from which the Clydesdale horses have emanated, were bred from old English stock in the Shire counties, of which the large, strong, distinctive English cart-horses of the present day have come, dating back to the law of breeding enacted in I54I in the time of Henry VIII., and are world-noted for their weight and serviceable action.

The ancient design in breeding the Shire horses was for purposes of war, and to give powerful horses to carry cavaliers in heavy armor for tournaments, and for the various pageants of state solemnities, as well as for cavalry and military purposes.

Being a member of a prominent London horse society, of which Sir Walter Gilbey was the organizer and first president, I was invited to a dinner given annually by Sir Walter at his town residence, Regent's Park, to the president-elect and council of the Hackney Horse Society, of which the Prince of Wales was at the time president. It was a very distinguished gathering of the Prince of Wales, the Duke of Portland, the Earls of Londesborough, Coventry, Enniskillen, Lords Horthfield and Brooke, Baron Von Schroder, Viscount Combermere, Sir Dighton Probyn, Sir Selwyn Ibbetson, Sir Nigel Kingscote, and a few others of prominent note. I was the only untitled one present. It was quite informal, and all went merrily.

The Prince came somewhat later than the hour assigned-half-past eight - a feature not usual at London dinners, but quite excusable in his instance, for which no apology was made. In fact, it is not good form at London dinners to make excuses for lateness, and thereby draw attention to the first mistake, for 
which guests are favorably lenient, well knowing that only a very strong reason exists for tardiness upon an occasion where promptness to fill is so well understood. I remember an occasion in London of a dinner I attended scarcely less important than the one first mentioned, when nearly all were from fifteen to thirty minutes late, owing to one of those dense, suffocating, sooty fogs, which sometimes in the autumn drop down on the streets of London. In this instance the pasty gloom of smoky moisture was so dense that my cabman had to lead his horse by the non-penetrating glimmer of a lantern, constantly impeded by corresponding vehicles travelling all sorts of ways, and, although I started well in advance of the dinner hour, I was nearly half an hour late, as were most of the guests. In this instance the delay was so general, and the cause so well understood, that it was the subject of general pleasant remark.

The dinner given by Sir Walter was quite simple, and so considered by the Prince, who remarked as he glanced over the menu, that he considered it a model bill of fare, and that he should take it home to show the Princess, putting the menu in his coat pocket, which act I thought well to follow on my part, and, withdrawing it now from a package of old papers, I will give it exactly:

\section{(Gilbey Crest)}

Cambridge House, London, N. W.

Dinner to the President (H. R. H. the Prince of Wales) President-elect, Past President and Council, Hackney Horse Society.

Tuesday, 3d March, I89r.
Oysters.
Turtle Soup.
Clear Soup.

Tweed Salmon (Carham).

Soles, Slips.

Whitebait. 
Breast of Chickens, Filleted.

Woodcock.

Guinea Fowl.

Asparagus (Argenteuil).

Forequarter of Lamb, French Beans.

Duckling.

Sweets: Savoury. Green Peas.

Champagne: Ayala's Brut Vintage, I884.

Madeira: Cossart's Secco Reserva Colheita de 1836 .

Hock: Schloss Johannisberger Auslese Vintage, I868.

Champagne: Pommery's Vintage, I874.

Claret: Mouton Rothschild's Vintage, 1875 .

Port: Dow's Dry, Vintage, 1863.

Claret: Château Margaux Vintage, I875.

Sherry: Gonzalez's Vintage, I847.

Port: Croft's Magnums Vintage, I 8,34 .

The floral furnishings of the table were of rare and expensive exotics. After dinner the Prince of Wales and most of the guests remained, upon adjournment to the smoking and coffee room, until twelve o'clock, all in pleasant conversation. I had occasion to remind the Prince of his early visit to America and Boston in his nineteenth year, and that I had the pleasure, being Corporal of the Guard of the Independent Corps of Cadets, of doing guard at the Massachusetts State House, in the lunch room, partaken of by the Prince and suite. At that time N.P. Banks was Governor of the State, after whom the Prince particularly inquired, and referred to his martial bearing on horseback in the review of the State troops, and was desirous of learning of his after career.

Not long afterwards I attended the exhibition of the English Cart Horse Society in London, of which I was a member, and I invited our American Minister, then Mr. Lincoln, to accompany me, which he did, and 
we entered the private enclosure adjoining the royal box reserved for members and friends. The Prince was to distribute the prizes given in award, and we seated ourselves one on each side of Mr. Lawson, owner of the London Telegraph newspaper. Mr. Lawson had acquired much wealth in the publication of his paper, and it was a well credited rumor that Mr. Lawson had 1ately accommodated the Prince with a loan of $£$ I00,000 as the wants of the royal heir had been much in excess of his large income, and it was estimated at the time of his accession to the throne of England after the decease of Her Majesty the Queen, that his existing personal indebtedness exceeded a million pounds sterling, all of which was undoubtedly liquidated from the very large fortune he inherited from his mother upon his becoming King.

Upon the arrival of the Prince in the royal box, attended by the Duke of Portland and a few equerries, he looked over the adjoining box, which was spacious, as well as his own, and sent his equerries with compliments to various prominent parties in the reserved space with invitations to join him in the royal box. Something of a thinning out from the reserved box occurred, and Mr. Lawson evidently expected to receive the royal invitation, and seemed to experience an agitation palpable to Mr. Lincoln and myself as the thinning out occurred without a royal summons for him, and when an equerry presented an invitation to Mr. Lincoln and myself, Mr. Lawson rose with us and made his departure from the exhibition. He has, however, been knighted since the Prince became King, and the omission of him from an invitation was doubtless an intended act upon the part of the Prince, since Mr. 
Lawson was credited with the authorship of the rumor about the loan. The position of the Prince was too substantial to require any exertion upon his part to find ready money when needed from the many affluent capitalists existing in London who would feel highly honored by being creditors of the heir-apparent.

I met the Prince again at a presentation made to Sir Walter Gilbey, representing the subscribers to a fund of a thousand guineas for a testimonial subscribed by a thousand admirers in England at one guinea each, to which I was a subscriber. This was proposed and headed by the Prince of Wales and almost immediately filled, and Sir Walter elected to have for the thousand guineas his half life-size portrait painted by the eminent English artist, W. Q. Orchardson, which was duly presented, and was the occasion for another dinner given by Sir Walter to the Prince of Wales and some thirty of the prominent subscribers, among which I had the pleasure of being invited.

My acquaintance commenced with Mr. Orchardson on a salmon stream in Scotland, where we were the guests of a mutual friend, and I was much charmed with his piscatorial skill and his ardent devotion to angling. Our acquaintance cemented into an earnest friendship, and we had many pleasant rambles together. I was not aware at our first meetings that he was the most celebrated portrait painter in England, and distinguished for his Meissonier-like fidelity of detail. Renewing our meetings in London, I was often a visitor at his studio, but only by his special invitations, for I knew too well the error of intrusion in the sacred hours of labor given by painstaking and devoted artists. Mr. Orchardson, although so prominent in the artistic line, 


\section{A Sportsman}

was a gentleman of most simple and unostentatious bearing, but whose countenance was one of the most attractive and impressive cast, and bore the imprint of his studious fidelity and painstaking industry, yet was most modest and retiring in disposition.

I felt quite highly complimented when personally invited to the dinner, in being informed by Sir Walter Gilbey that he had also invited Mr. Orchardson, since he was the creator of the souvenir picture, but that his retiring disposition had induced him to avoid the prominence of that occasion until informed by Sir Walter that I was to be present, when he said he would attend if he could sit beside me. That was very pleasant for me to hear.

After dinner while I was engaged conversing with Mr. Orchardson on sporting matters, we were joined by the Prince of Wales and the Duke of Portland, and the latter interested us in an account of his bear hunting in Russia a few years before. It was the habit often to get after bear in the winter after they were in their hibernating quarters, when the peasants, finding such localities by the open perceptible breathing holes, would mark the spots and dispose of finds for a compensation, and his host having secured several, invited him to join in the hunt. Accompanied by a pack of dogs, the latter, on being brought to the localities, would, by digging at the holes and barking, soon fetch out the bears from their slumberous repose, which would be shot or overcome by the dogs. Several were killed, and one nearly cost the Duke his life by being shot at on his appearance by an excitable Frenchman guest, who, being behind the Duke, recklessly fired his gun between the body and arm of the narrator, nar- 
rowly escaping his body, but taking off a considerable portion of his coat. These bear were of the very large brown species, and despite their supposed somnolent condition would put up a very ferocious fight upon being aroused.

IN the month of June, I864, I made an excursion to the Grand Lake stream for land-locked salmon (Salmo confinis), landing at Calais, Me., and by small steamer with a few friends by the St. Croix River to Grand Lake stream, where we built and occupied a birch-bark camp on the shores for ten days. We found the fishing particularly good, and had no difficulty in repeatedly taking doublets. We found the salmon lying at the head of the little falls and eddies and full of life. In fact, they are more lively than trout, and a strictly high quality game fish. Although plentiful in the stream and the Grand Lake above, they seldom run up over five pounds in weight, and it was not often that we caught one over three pounds, while the average would be about one and three quarter pounds.

Since that period the Fish and Game Commissioners of the State have introduced the land-locked salmon into many hundreds of the ponds and lakes of the State, and the introduction has been almost invariably successful.

At the time of this excursion this salmon did not exist in more than three separate waters of the State. One of the most important auxiliary benefits to this fish has been the introduction of the salt water smelt, which seems well adapted to nearly all fresh waters, where they multiply to an amazing degree, supplying a 
most important food for the larger fish, particularly land-locked salmon, trout, and black bass. In some of the larger lakes of the State, although the smelts do not grow to a larger size than two or four inches in length, and may be observed in the spring plentifully dead on the surface of the water from some unknown cause, they can at the same season be netted by the barrelful in some localities adjoining their spawning places, and furnish without dressing in imitation of white bait, a very palatable dish simply fried in pork fat, beef drippings, butter, or olive oil.

In a few lakes I have observed there is a run of larger smelts than the usual, as in the Rangeley waters, and this season (I904) I caught one of nearly a quarter of a pound in weight on a small fly while casting for trout, and have seen one which weighed half a pound. As a fish food element in fresh waters, the smelt may be accounted of the first importance in its adaptability and fecundity.

The flavor of the salmon is more or less affected by the waters it inhabits. I was a member of a California club which was the first, and I think as yet the only one to introduce this fish in that State, in Crescent Lake, on the Shafter ranch, at Point Reyes, where they grew with unparalleled rapidity in less than three years, from six inches in length to four and five pounds in weight, but owing to a scarcity of small food fish, and living largely upon the plentiful caddis larva, imbibed a disagreeable flavor, though eager fly takers and of full game action.

On Grand Lake stream we met two enthusiastic disciples of the gentle art, Mr. Edward Lannegan, the actor, and W. H. Venning, since for many years a Canadian 
commissioner of fisheries. Near our shelter was the site of Dr. G. W. Bethune's camp, for many years occupied by this gifted and eloquent divine of New York, who was a most devoted fisherman and lover of Nature, and who had died in Italy two years previously.

One of our party was Walter M. Brackett, of Boston, the distinguished and celebrated painter of fish, especially trout and salmon, whose pictures ornament the houses of many foreign purchasers, and whose completeness in presenting on canvas the subject of his art has never been excelled. From his youth up he has been devoted to the piscatorial art, much undoubtedly at the expense of his time, which could be given to the gaining of golden results; but with him of secondary interest, though dependent upon his profession for livelihood. But his palette and brush were always laid aside whenever an angling friend visited his studio, for the entertaining comparison of fishing experiences. Now, at the age of eighty, still active and vigorous he pursues the bent of his inclinations in annual visits to his salmon stream in Canada. At his living rooms and studio in the upper part of a house on Tremont Street, where he has resided for nearly half a century, I have passed many pleasant evenings in his genial society and with mutual friends, and owing to his peculiar attractiveness $I$ have met many prominent people there, distinguished in politics and the arts, Henry Ward Beecher, Robert Ingersoll, Anna Dickinson, "Petroleum V. Nasby" -whose amusing letters were the particular delight of the lamented President Lincoln-Edwin Booth, William Warren, the favorite comedian of Boston, and others; and many pleasant sit downs in the evenings I have had there to 
a broiled trout or shad, and a sparkling bottle, with an invited guest or two. Several evenings were thus spent with the genial Robert Ingersoll, who never failed to put in an evening there when in town,

A curious incident occurred from this trip concerning Mr. Brackett and one of our party, Mr. Edwin Churchill, of Portland, a merchant extensively engaged in the West India business. At the request of the latter, a sketch was made for him by Mr. Brackett of our picturesque birch camp, and of the surroundings, showing the stream and scenery, which was afterward elaborated in an oil painting. Somewhat to our surprise, upon taking passage on the steamer from Portland to Calais, Me., we found Mrs. Brackett and her only child, Artemas (now an artist of some celebrity), then nine years of age, who were to accompany us upon our excursion. Although Mrs. Brackett was a most agreeable woman, possessing a strong taste for outdoor life, and tastes similar to those of her husband, and generally accompanying him upon his excursions, we were somewhat surprised to find that she was to be one of our party upon this excursion, to a region then considered pretty well on the frontier. When the picture was completed and forwarded to Mr. Churchill, he was a good deal astonished to find Mrs. Brackett, holding the hand of little Artemas, depicted prominently on the bank of the Grand Lake stream. This was not very agreeable to him, as he had evidently believed that he was obtaining a souvenir of an episode in the wilds of Maine, where exposed to possible privation and more or less of rough life, the picture would excite a peculiar interest among his family and friends. To have a well attired lady, and child of tender years in 
bold relief amid the otherwise primitive surroundings, destroyed in his view the particular features he wished to convey.

There is a very sensitive sense existing with painters, poets, and in fact with all artists, in having their works changed after completion by others, and it is deemed very unprofessional, and contrary to good form, for rival artists, however critical they may be in review of merit, to personally amend or touch up the works of others. Mr. Churchill, feeling a delicacy, in opening up the matter with the artist, employed a somewhat prominent painter in Portland-and it is somewhat surprising that he should have undertaken the change- to bury Mrs. Brackett and her son beneath a huge boulder, which restored the primitive appearance of the picture. By some means Mr. Brackett heard of the liberty which had been taken with his work and the metaphorical interment of his family, and became much incensed; which led to an acrimonious correspondence with the Portland artist, which finally found its way into the papers, and was continued at some length.

When our time for leaving the pleasant shores of Grand Lake stream arrived, I felt very loath to go away, and the day before breaking camp, two Indians came along in a canoe, bound for the wilderness of ponds and lakes above for wild cranberries and muskrat skins, with whom I made an arrangement to go on, and made a somewhat reluctant farewell to my comrades, wno were to return to civilization. In this canoe excursion we passed over a dozen lakes of from five to fifteen miles in extent, in a wilderness of waters and forest, camping for two or thsee days here and 


\section{A Sportsman}

there when favorable for the pursuits of the Indians, while I followed my fishing inclinations, and in shooting small game for the larder, partridges and ducks, though not plentiful, were sufficient for our wants. Our trip, covering three weeks, extended over the Machias lakes and ponds, and up the Fifth Lake stream to a lake of the same name, and over the Compass and Duck lakes to within forty miles of Bangor, where I took conveyance to that city.

It was very interesting to follow from lake to lake over the old Indian trails familiar to my guides, where a carriage of our canoe was necessary. The two Indians secured an abundant supply of muskrat skins with their traps, as well as cranberries. These Indians had a decided preference for the young muskrats as an article of food over any other, and I, commencing somewhat hesitatingly at first, found them exceedingly sweet and palatable. The muskrat is not a carnivorous animal, being allied to the beaver, living mainly upon succulent water-growing roots, and vegetable foods, although partial to fresh water clams, abundant in Maine waters. It is a nocturnal animal, and a very interesting one, building mounds of a few feet in height for winter quarters, where their comfortable grass beds are found. Many of these mounds are connected with the shores by under water routes, which they take care shall be deep enough to keep from freezing over, and connect with subterranean earth galleries. The farmers and natives often conjecture concerning the severity of the coming winter by the dimensions of the muskrat mounds, and it has been observed that however severe the floods, the muskrats' mounds are sufficiently prepared for them. 
How shall we account for this apparently abnormal faculty indicated by animals, birds, and fish, so plainly evinced in many instances? I am reminded of the almanac maker, who prophesied the condition of the weather in advance, who, pausing on a country trip to inquire the way of a farmer engaged in feeding out corn to his ranging swine, was given his route with the advice to make haste for his somewhat distant destination, as a storm was coming on. To this he responded that it was not likely, as his almanac claimed a fair day. Going on, he was overtaken by the storm and wet through. Returning the following day he had the curiosity to ask the farmer how he knew a storm was coming on when the conditions for pleasant weather were so evident? To which the farmer replied:

"Oh, my hogs know more than almanac makers, I could tell by the way they acted."

The muskrat is much better adapted for rapid progress through the water than on land, being webfooted and possessing a flat, scaly tail of good length, admirable for guiding its body. The hind legs and feet are blady or thin, by which the rat can swim rapidly and feather the oar, so to say, in a perfect manner, and will go for a hundred feet under water without difficulty. A peculiarity about the animal is its musky odor, and if the supplying glands are not removed in dressing, the odor may be found rather too powerful for ordinary appetites, though my Indian comrades would not take the trouble to remove such sources, had I not insisted upon it.

One feature of prominence I observed in the muskrat. That of its extremely pugnacious character, as 
indicated, not only by its ferocity shown when trapped and alive, but on the scarred skins taken from the bodies of the males, indicating sanguinary battles which must occur among them at certain seasons of the year. Nearly every male skin taken exhibited numerous scars, and a few old ones were so fur-bitten as to make their pelts worthless. These animals, as with the beaver and otter swimming below the ice, have a faculty of expelling the air from their lungs, which rises beneath the ice to the under surface, of sucking in the globules of air and thus renewing its supply. This is frequently taken advantage of by hunters with otter which have been driven into the water beneath a thin ice, where their movement could be observed and followed, by striking an axe hole over the air bubbles, and by this wear out the object of pursuit, until completely exhausted, when it would be secured.

On the Schoodic group I found one five feet higher than the one below, connected by a small stream at the head of which was an old log dam, pretty well decayed. Here, camping for the night, we broke away a portion of the dam, letting a good flow from the upper lake into the lower, over the old stream bed. As it looked promising in the morning when the flow reached the lower lake, I made a cast, getting a rise, and at the second, hooked a fine salmon, followed by one or two more, and apparently could have secured more, if desired, showing the attraction of moving water at that season for the salmon below.

Deer were plentiful, and I could have probably secured several, if any necessity had existed, but at that season the does were with fawns, and we had a 
surplus of food. Scarcely a day passed without seeing deer in the morning and at night, feeding or wading along the lake shores, or in the water, and several nights we heard them in the vicinity in the adjacent woods. Moose were not so plentiful, though we saw two, both cows with calves, and one passed along the water front near us with its calf, as we were preparing our evening meal, so near that it could probably have been brought down with a charge of buckshot. But to have killed a noble animal of this magnitude in our situation would have been criminal, and I have had several instances since that period when I have seen this mighty animal, which has always seemed to me to have been a survival of the ancient days, pass before me unmolested.

In some of the small streams connected with the Schoodic salmon waters, I frequently caught on my fly while casting for brook trout, the smolts of the land-locked salmon, which generally remain in the streams when hatched for the first and sometimes the second year, and which rise readily to the fly.

I $N$ I869 I made an excursion with a friend, from Cheyenne in Wyoming to the Laramie Mountains for elk and deer which we found plentiful, and for trout in the branches of the Laramie River. The trout were tolerably gamy, but not equal in that respect or in flavor, to the eastern, and we soon had our fill. Wyoming for many years will afford a great field for sportsmen having a great variety and plentifulness of game.

We then proceeded on by the Union Pacific Rail- 
road to Provo City in Utah, and passed several days at Utah Lake, a large fresh water body of about twenty-five miles in length by five or six miles in width, and one hundred and twenty-five square miles in area, situated thirty miles south of the Great Salt Lake. We found this a magnificent sheet of water, abounding in lake trout of a large size, where we caught by trolling all we could desire, and in fact gave away many to the neighboring Mormon settlers. This lake has since been stocked with bass, whitefish, and carp and now affords a very large quantity of food for Salt Lake City, Ogden, and the surrounding country. The large lake trout natural to the waters are especially plentiful, and we saw a seine hauled in while we were there containing several hundred pounds of the large brown trout.

Carp and suckers, generally considered unfavorable food products, are given prominence in recent returns of the industries of Utah among the products of Utah Lake, and yielding of the latter, nearly a million pounds in 1895 . Owing to the altitude of 4000 feet and the coldness of the water, the suckers are esteemed for food more than those taken from warmer waters.

The Great Salt Lake, a singular phenomenon of nature in its extreme saltness - similar to the great Dead Sea and a large lake in Persia and some in South America-is entirely devoid of fish life, containing one third of salt, and in density so great as to float the human body with ease. It is larger than the State of Rhode Island, and half as large as the State of Connecticut. Although it receives annually 
large quantities of fresh water from several streams, and the natural drainage of a large basin with no visible outlet, it has been of late years constantly receding, and in my remembrance has diminished its extent by over ten miles. It is comparatively shallow, its extreme depth being but sixty feet.

Many have supposed that this lake had a subterranean outlet but its shrinkage is most likely occasioned by evaporation. In my memory Lake Tulan (Tulare) a large body of fresh water in Southern California, covering several square miles, has about disappeared by evaporation, and now most abundant harvests are being grown over the old lake bed. In the earliest days of California this lake was described as covering over one hundred square miles.

Lately the Union Pacific Railroad has made a considerable reduction in its route by building a trestle bridge of over twenty miles in length across a shallow part of the lake. The evidence unmistakably upon the neighboring mountains shows that in some remote period this lake covered a very much larger area, probably six or eight times more than at present, and had a depth of five or six hundred feet. Three very distinct benches, or water levels of prominent extent, are shown on the east side of the lake upon the mountain sides, where the waters of the lake must have washed for long periods on three clearly shown levels, separated from each other by from one hundred to two hundred feet. These levels are distinctly visible to the passengers from the passing railroad.

From Utah Lake I passed on by the railroad to Ogden, which is now, but was not then, the connecting place of the Union Pacific with the Central Pacific 
on to California. The connecting point at that time was at Promontory, some seventy miles west of Ogden, a barren and desolate place, undesirable for a union place of two prominent railroads, and the intervening distance east was acquired by the Central Pacific Railroad from the Union Pacific, giving each road many advantages over the barren Promontory. The racing of both roads building across the continent under the Enabling Act of Congress-so bountiful in the giving of the credit of the government in its guarantee on the second mortgage bonds, and outright gifts of many millions of unoccupied land-was eager and exciting, as I was witness of, from frequent passages over the building routes from 1865 to I 869 . Despite the enormous aid of the government, and the immense stakes worked for, there were periods during the building when the distinct bodies of workers on each side of the continent were at their wits' ends to provide ready means to meet their expenses. Immense discounts were made in the selling of the bonds, even those guaranteed by the United States government. It was at a time when the credit of the government was largely strained by the necessity of providing over three thousand millions of dollars for the expenses of the Civil War, when at times a dollar of the United States government was not worth fifty cents on a gold basis in the markets of the world.

The government required the iron rails laid down to be of American manufacture, which cost both roads at many times, over one hundred dollars per ton, and which in some instances were laid over native iron beds, from which Bessemer steel rails have since been made, and much superior to the wrought iron used, 
at less than one fifth of the cost of the former. Still despite all obstacles, the reward was promising.

The iron rails could not be obtained readily enough to keep up with the grading, and the latter stretched out hundreds of miles beyond the track-laying, and from Promontory where the final rail-laying met, graded tracks stretched out in a total of several hundred miles beyond the place of meeting, still existing monuments of lost labor.

The government aid to the building of the Union Pacific and Central Pacific Railroads across the continent was one of the most broad-minded and comprehensive plans ever conceived by any government, and at a period of financial condition when most men would have shrunk from undertaking the great perils involved; but it was carried through in the briefest period in which any similar enterprise of that character was accomplished, uniting the Atlantic and Pacific oceans by a direct route of 3300 miles. The government at that time was at an annual expense of over six millions of dollars paid out for wagon transportation to its military stations through the wilderness, which railroad carriage largely diminished, besides advantaging the rapid subjugation of hostile Indians which imperilled settlements. The building of the great Transcontinental route also encouraged the rapid building of many auxiliary roads, followed by extensive settlements and the increase of new industries. Many objections were made from various quarters to the advancement of government funds and credit, yet every dollar advanced was paid up with interest in full.

The enormous advantages of railroad building in 
the United States, equalling in extent all others in the world, is exhibited in the immense harvests now grown and marketed, and in the large exportation of manufactured articles. Consider alone the magnitude of the corn crop of the present year estimated at two billions and a half of bushels, and perhaps more. How difficult to realize the magnitude of its bulk and value from a mere recitation of the words "two billions and a half of bushels!" Load it up in the railroad cars and see how long a train it will make. Calculate 30,000 pounds to a car, and a bushel at sixty pounds, and the length of the cars at 45 feet with couplings, and you have a train of over 50,000 miles, enough to go around the world twice.

Little wonder that good railroad business depends upon good crops, and such as we have this year, 1905, and have had for the past few years give great prosperity to this wonderful resourceful country of ours.

At Ogden I found a special Pullman car occupied by several Union Pacific Railroad directors going to Salt Lake City over the new railroad just completed, wholly built by Mormon labor, afterward acquired by the Union Pacific. Accompanying this car was Bishop Kipp, of California, and Commodore C. K. Garrison, of New York. I was invited to join the party over the new road. In our passage down from Ogden we passed through a short tunnel which had not been completed quite wide enough for our car, though nearly so, and going at a fairly brisk speed, we were shaken up and alarmed by our car striking, on both sides of the tunnel, projecting points of rocks, which considerably damaged our car. We went through, however, all right, keeping the rails. We 
called in a body upon that remarkable man, Brigham Young, who received us most cordially, and who entertained us for two hours in conversation about the Mormon situation, and various subjects. He expressed himself as not seeking the advancement of railroads in Utah, but yielding to the inevitable, considering that such were by no means essential to the further success of the Mormon Church, evidently feeling that more years of the undisturbed conditions before existing would be desirable to strengthen Mormon interest, and referred to the already invading elements becoming evident, particularly to the reluctant giving of a license by Salt Lake City for a saloon, where intoxicating drinks were dispensed, one of which had now been established under the high tax of $\$ 3000$, and it had been a question if the tax should not have been so high as to have caused prohibition. But since the railroad had come and with it an influx of foreign influences, the situation must be met as efficiently as possible, and he had no fears about the growth and success of the Mormon Church which was destined to yet leaven the whole world within its true faith. The arrival that day of a perambulating circus at Salt Lake City he was glad of, which he should attend, and highly approved of, and thought it would be highly acceptable to the Mormon people, who had been debarred from such entertainments. The next day being Sunday he invited us to attend the services at the Tabernacle, and to Bishop Kipp, extended an invitation that he should assist in the services. This invitation the Bishop accepted, and we were promptly at the Tabernacle, where special seats in front were reserved for us. The old Tabernacle, now superseded by the 
elegant granite Temple, seated some six thousand, and contained, as President Young informed us, the largest organ in the world, excepting the one in Music Hall of Boston, and had been made entirely by Mormon skill and labor. The Tabernacle was crowded to its extent, and the audience was garbed in somewhat different costumes from those seen in Eastern city churches. The large poke bonnets, now unseen, were in evidence, and many long-tailed blue coats with brass buttons were frequent among the Eldersrelics of former days from foreign countries. Despite the quaint costumes of severity, it was evident that Gentile influences were commencing to be felt by some of the younger portions of the congregation, in a displaying of colors which were not entirely sombre. These were the occasion of some remarks on the subject by President Young during his address, when reviewing the vanities of the world, and the tendency of the female sex to follow the fashions of the ungodly, which were vain and irrelevant to true piety. The sticking in of gay feathers, as he designated it, while appropriate to the male domestic fowl, growing where nature designed, could not be availed of by the Christian woman without a sacrifice of modesty and religious regard, - this with many admonitions of being on guard against some of the possibly pernicious features likely to be introduced by the influx of settlers, which would follow the building of the railroad in the development of the mineral and agricultural wealth of the region. The audience was very orderly and attentive and it was clearly evident that the head of the church had a powerful influence over and complete control of his hearers. 
The Bishop, accepting the invitation which had been extended to him, made what I considered a most excellent sermon. He was guarded, and properly confined his remarks to general subjects. $\mathrm{He}$ was liberal in religion and above prejudice, and made a strong argument upon the advantages of Christianity, and expressed the belief that all honest workers would ultimately be gathered together in the bosoms of Abraham, Isaac, and Jacob, and enjoy the reward of their virtues. Warming up with his subject he dilated upon the great satisfaction difficult to express, which would be experienced in that last resting-place which he compared with the joy which would be experienced upon arriving at the home of our childhood. And looking around over the remarkable collection of Mormons from all parts of the world, dressed as they were in the diversified garbs of their nationalities, he dwelt at length upon the homes of childhood, the old house with its possible vines clinging to the portal of entrance, the old familiar trees under whose shade so many pleasant hours had been passed, the wild flowers of the field, the cold water of the old familiar spring, the old swinging gate so often freighted with its infantile weight, the merry laugh of childish glee, the mother's fond smile and pleasant words, all were but a reflection of the joy and never-ending satisfaction of the heavenly home.

During this delivery, Brigham Young seemed strangely agitated, rising and taking several drinks of water from an adjoining table, and seemed several times upon the point of interrupting the Bishop. The latter had no sooner completed his address than Brigham Young, taking the pulpit, commenced one 


\section{A Sportsman}

of his characteristic sermons, in which he scored the Bishop in language both forcible and plain. He said, the Mormons could follow the Bishop in all the teachings of the Bible; but that the Mormons went much farther owing to the light of new revelations, and through which the Mormons, as the chosen people of the Lord, were yet to have the wealth of the world poured into their possession, and that the Bishop need have no fear but the Mormons would be entirely at home in the bosoms of Abraham, Isaac, and Jacob, and the old patriarchs of the Bible, as they would be among the polygamists of the Lord. And so far as likening the satisfaction of heaven with that of revisiting the old homes, he would have none of it, nor would any of the Mormons. They had had enough of it; they had tried to cultivate the old homes, but they had been driven forth into the new land of promise; they had been driven from pillar to post; they had settled several homes before they came to Salt Lake City, and for himself, he had been glad enough to shake off the dust of the old home, and get away with an old brokendown horse and wagon, and he did not want to hear any more about it. If there were any of the Mormons who wanted anything to do with the old home, they had better get away as soon as possible, as they were not fit for the inspired selection of the Lord.

The circus was a great affair for the Mormons. It was a sort of second-hand humdrum outfit, accompanied by a few dusty elephants and camels, with a sprinkling of wild animals in cages. But it was the real thing for Salt Lake City, and it was very amusing to witness the excitement that occurred, when the gilt chariot containing the band made its appearance, 
heading the procession of elephants and camels, and cages of animals, followed by the usual horses and trick ponies and spangled clowns. The whole town seemed to be out and aroused. Old men and women; fathers and mothers, fast holding their children in hand, clogged the streetways, and followed the procession to its end. It was the first glimpse of high life the Mormons had had the great joy of seeing, and no triumphal return of the ancient Cæsars through the streets of Rome laden with spoils and captured chieftains could have been a greater event for the populace.

For several days and nights the circus held out with crowded tents. Brigham Young had his liberalsized family box for fifty or more, which gave the signal for all hands to turn out, and it is doubtful if any good Mormon failed to do so. It was as good as seeing a circus alone to witness the general heartfelt enthusiasm of the audiences, and the outbreaks of laughter and applause were certainly beyond anything the circus had ever experienced before. The bareback riders, the spangled clowns with their old worn-out jokes and witticisms, became new, and Salt Lake City received its first baptism of high life and sports.

THE Dominion of Canada, comprising an area equal to that of the whole United States, including Alaska, is one vast hunting and fishing region, which should furnish satisfaction to sportsmen for ages to come. Being prolific in lakes and rivers which can be kept teeming with fish-life from breeding, and with 
over a million and a quarter square miles of comparatively unbroken forest for the shelter of game, it will be difficult to find the world over an equally inviting region for sportsmen.

Salmon fishing, the first among fishing pleasures, is comparatively limited in extent along the Atlantic coast of the United States, but extensive in Canadian waters and in the coast streams to and beyond Labrador.

I have made a number of excursions for salmon fishing to various Canadian streams, where I met with particular success. From the Gulf of St. Lawrence and the Bay of Chaleurs a number of prominent salmon and trout streams diverge, notably the Restigouche, Metapedia, and Saguenay, and on the Restigouche, near the Metapedia settlement, is a remarkable salmon pool about half a mile in extent, where in some seasons as high as six thousand pounds of salmon are taken with the fly. In 1879 and I880 I passed in the season several weeks there, on some days taking eight or ten good fish.

At the time I visited the section, one Frazer-a huge, good-hearted, easy-going Scotchman, who owned the land about the pool, and for a mile or so from it above and below-carried on farming and had a congregation of buildings, and a moderate-sized hotel where he accommodated fishermen, who then were few in number, charging, besides board, for the privilege of fishing, five dollars per day, which included one of his boats and two Indian guides.

Frazer, although a Scotchman, was an exception to many of his nationality, who are noted for their canny and thrifty habits, and he found farming a very 
moderately paying interest, and having a large family, and keeping continually a lounging crowd of Indians for occasional use, who fed upon his subsistence, was a good deal embarrassed financially, and besought me to buy out his holdings, which carried the riparian right of fishing, as held under the laws of the Province of New Brunswick. His asking price was $\$ \$_{3}, 000$, giving him a bonus of $\$ 3000$ over the existing mortgage on his place, which being overdue was pressing upon him. I thought very seriously of taking it, considering the value of the salmon pool, but hesitated and let it pass in view of my camp established at the Rangeley lakes, which pretty well satisfied my fishing tastes.

I mentioned the subject to a friend of mine, who made the purchase, and who turned it over in a few weeks to the now celebrated Restigouche Club for $\$ 30,000$. This club, starting upon the property as its basis, on a formed capital of $\$ 100,000$, with one hundred shares at \$1000 each, and securing adjacent properties, is now the most prominent and wealthy fishing club in the world, composed mainly of wealthy New Yorkers, and the shares of the club when changing ownership now are appraised at $\$ 10,000$ each, and are only disposed of in exceptional cases. It is doubtful if the Restigouche pool could now be purchased for a quarter of a million dollars.

In the vicinity is a village of Micmac Indians, who were once a powerful tribe inhabiting the coast line of Southern Canada in the early days of white occupation, warlike and aggressive, sun-worshippers, and devoted wholly to fishing and hunting. Peaceful with the French settlers, they quarrelled with the English upon their gaining the ascendancy over the French, and 
boldly attacked the English settlements, and had no hesitancy in plundering English vessels on the coast, and in several instances engaged with armed ships sent against them, and are credited with having taken over a score of vessels in the Bay of Fundy. They were finally broken up, as hostile Indian bands have invariably been, and the village on the shore of Chaleurs Bay now represents the tribe, where they are advanced in civilization, having a grammar and printed parts of Scripture and books of devotion in their language, partly in phonetic characters and type; and to see them going to worship on the Sabbath one would think a large portion of them were whites, so neatly dressed and lightcomplexioned are they. A rivalry in religion exists among them, as with humanity in general, part being devoted to the Catholic religion and others to the Protestant, results of their early teachings from the French and English.

Among these Indians are the most skilful salmonfishing guides and hunters to be found anywhere. The adroitness of those Indians in poling a canoe, standing up, one at the bow and the other at the stern, over the foaming waters, amid falls and rocks is marvellouspushing and guiding the canoe with long spiked poles, with rapidity in smooth water, and slowly forcing it up the falls in narrow passages between threatening rocks, and all in perfect safety and freedom from splashing water. With my wife I made many of these river excursions, which I shall always remember with delight.

I had an amusing incident with one of my two Indian guides. One, Louis, was of extraordinary expertness and very steady in character. The other, Joe, was heavier, but by no means clumsy. He would 
fail to turn up on occasional days after being paid off, and his appearance when coming on again created an impression in my mind that he had been on a bacchanalian revel; and I was informed that he was not averse to such occasions, and that his squaw often collected his dues from Frazer for herself and children at home, resulting sometimes in a more highly opaque coloring to her visual organs than before-for, sad to relate, Joe had the reputation of being a wife-beater. I had reason to think that my stock of Jock Scots and sundry flies from my flybook were to some extent depleted while in his care during meal times, which might, however, have been unaccountably blown away.

One day I lost one of my sleeve-buttons from my cuff, which I had observed hung loosely while I was engaged with a salmon, and was missing when I went to my noon meal, and which I supposed might have dropped in the boat. It was one of a very valuable pair to me, being made up of two ancient silver coins of the Roman Empire which I had obtained in I 868 from the ruins of Pompeii, with other relics from the excavations there. When I returned to my canoe for the afternoon fishing, I informed my guides of the loss, but they had seen nothing of the button, and the boat was clean and drawn up on the shore, bottom side up as usual. A diligent search was made at the landing where the boat was drawn up, but without result. I was quite annoyed at the loss, and somehow felt a telepathic impression that Joe knew something more about it than I did. Thinking it over in the afternoon fishing, I concluded to make a new approach to Joe on the subject and to offer him five dollars if he could succeed in finding the button, which I felt sure must be some- 
where about the landing, covered over perhaps by the shingle or loose earth. Joe came smiling toward me the following morning with the lost button, which his careful search had discovered about the landing, and received the reward of his honesty, which caused his absence during the two following days, passed in the celebration of his fortunate find.

I had a curiosity one evening to make a rough calculation what one of these old Roman coins would amount to if placed at six per cent. interest and compounded from the time of the destruction of Pompeii by the eruption of the blown-out volcano which originally occupied the site of the present Vesuvius, in the seventy-ninth year of the Christian era. This exhibited the immense power of interest, which eats up the substance of original value, and untiringly proceeds day and night in its accretive growth. The value of this coin, which I estimated at an intrinsic value of ten cents, although worth probably a little more, would amount on the basis of doubling in periods of eleven years at six per cent. per annum, compounded, to the sum of $\$ 102.40$; call it $\$ 100$ for even figures. From the year 79 to 1905 are 1826 years; this divided by eleven gives a quotient of 165 periods of eleven years each. It will be observed that each period of eleven years gives an addition of three ciphers to the original sum. Therefore, in $6_{5}$ periods of eleven years each, there would be $495 \mathrm{ci}-$ phers to be added to the original ten cents, giving an amount which is not expressable in the language of arithmetic. Roughly square the circle of the earth, which cannot be done accurately, and a discrepancy in amount of the size of the moon will be of small account. 
Estimate then the cubic miles of the earth. Then estimating the value of gold at $\$ 250$ per pound, and the weight of a cubic foot at I 200 pounds, you can then gain the value of a cubic mile of gold. It will be found that it would require a good many hundreds of earths the size of ours of solid gold to pay the debt of ten cents borrowed in the year 79, with accumulated compound interest at six per cent. This should be a warning to lads and girls not to run in debt, but to save their money.

The sea trout fishing in the Restigouche and Metapedia and at the estuaries of branches of these streams I found very attractive. At times and places they would fairly swarm in numbers, and take the fly with great activity, and possessed the highest gamy qualities. The weights would average from one to two pounds, with an occasional three- or four-pounder.

There has been some discussion lately in Eastern sporting papers as to the identity of the sea trout. Some writers have agreed that they were distinct from those of inland streams, and this has been maintained with much force. For my own part I think there is no difference. All fresh-water trout will readily take to the sea if they can have access, returning to fresh-water streams for spawning, as do all of the salmon family, as a natural necessity. No fish undergoes a more rapid transformation than the trout when given a change of locality, not only in color and form, but in flavor. The proportions of the body also change in salt water. The body grows fuller, while the head, not increasing with the general form, appears smaller than with fresh-water trout of similar size. The brighter hues of fresh-water life fade away, and the 


\section{A Sportsman}

white silvery color increases. The flavor of sea-run trout increases in delicacy and the meat in curdiness. The sea trout often rise and take the fly intended for salmon in the Canadian rivers, and often to the annoyance of the caster. While they come early into the fresh-water streams, they remain late and afford much sport in the lower Canadian rivers after the close of the salmon season, and I have frequently lingered late in the year for this fishing, which is multitudinous in pleasant features.

No waters can be clearer than those of the Restigouche, which are of limpid purity, beyond any I have ever seen. The flow is over a bed where all alluvial matter seems to have been washed away, and after severe storms, when the volume of water is increased tenfold over the normal amount, and when one on the shore can hear the rolling of the bottom stones carried on by the abnormal rush, the water is still of transparent clearness. On one reach of the Restigouche in the autumn, where the water was shallow on an extended area, I observed from my canoe an occasional darting of trout; but owing to the clearness of the day and water, I could not raise one excepting from a very long cast, which was tiresome, and if I let my fly float down the current upon an extended line it was apt to sink and catch on the bottom. I attached two goose quills on my leader within a foot of the fly to float it, and let out my line a hundred feet or more, from which I had an exciting success.

IN California there are many attractions for the sportsmen in the endless variety of game birds and animals, and in the streams, where trout are plentiful, and 
in the sea, where the profusion of game fish exceeds those of any part of the world.

Several fish of great value have been successfully introduced, notably the striped bass and the shad, which abound plentifully and are furinshed at low prices in the market. Also the black bass, which seems to adapt itself admirably wherever it is placed. It is questionable if the carp and catfish, now plentiful, are of great value, and the carp, growing to a large size, are not sought for as an attractive food, and have become a source of particular annoyance about the tide-overflowed lands having a large area adjoining the bay of San Francisco. Upon these tide lands many sporting clubs were established, where ducks, plover, and snipe gave successful bags.

The carp, which may be properly designated as the grubbing hog of fresh waters, living largely upon the roots and growth of vegetable life, has made favorite feeding grounds of these semi-overflowed tracts and destroyed the snails and aquatic insects and tender plant life, so that the lands have become largely deserted by the birds formerly swarming on them, and many of the club sites have been given up.

The sport of hare coursing is one which is carried on in California more extensively than elsewhere in the world, for which the plentifulness of the hares and the many level fields give encouragement.

In California the hares called jack rabbits are plentiful, particularly in the southern part of the State, consuming such an amount of ground feed, and young fruit trees, garden vegetables, and grapes in the vineyards, as to be a great nuisance, necessitating periodical drives by which large numbers are destroyed. These 


\section{A Sportsman}

drives take place by concerted action over large tracts of land, without dogs or guns, by the assembled people of the district. An enclosure is made in the form of a sheep-shearer's clipper; a circle almost enclosed, with blades or arms extending out for an indefinite distance. The beaters, distributed on the outside of a number of square miles, of which the pen and extended arms are the centre, work toward it, driving all the hares, and often some other game which may be included, into the entrance passage, and on to the terminating circle entrance, where all are securely held by the closing of the narrowed passage-way. Incredible as it may seem, many thousands of hares are thus gathered in at a single drive, which are easily despatched with clubs. This same method was in vogue in the early days of Australia, by which thousands of kangaroos were penned up and slaughtered by the sheep men, and the same method has been pursued in various countries for many kinds of animals, up to and including the African buffaloes and elephants.

Why the California hares have not so plentifully increased in the northern part of the State as in the southern is difficult to explain, and why the little cotton-tailed rabbit which are such a scourge in Australia have not increased in California, where they were introduced many years ago, is difficult to understand.

Hare coursing is one of the oldest sports known, of which we have evidence in the representations on the Egyptian monuments and in the drawings and references in Persian literature, and those shown would indicate that but little change had occurred in the bodily form of the greyhound, excepting in the fringing, shaggy hair, which now has its representations 
in the Scotch, Russian, Danish, and other types. The old Irish greyhound may perhaps be considered the largest and most powerful of the class, and a match singly for the wolf. This dog, crossed with the great Danish dog and the bloodhound, has produced the powerful stag and boar hounds now seen. The English greyhound, however, presents the highest type of speed, docility, and beauty applicable for hare coursing, and has now been introduced so extensively in California as to be plentiful of a very high class.

Having attended several of the annual hare coursing meets at Waterloo, England, and seen some of the best prize-winners there, I am of the opinion that we have in California equally good dogs, and I think the hares in California are equal, if not superior, in speed to the English, from their having more open life, with more exposure to animals which prey upon them, and consequent activity. They are identical with the English hare, but vary somewhat in color from climatic conditions.

Hares, when pursued by the greyhounds, having their observation wholly directed toward the pursuer, from their orbital sight, will frequently run directly into a fence or post and be thrown back senseless, or directly into the jaws of an approaching dog from an opposite direction, and I have witnessed two occasions when pursued hares going at full speed were caught up by dogs held in leash by a man standing in the way, running directly into the jaws of the leashed dogs.

I had one two-year-old greyhound of good qualities, but a laggard in the chase, that would quit early and take his rest. While thus sitting one day, his running mate brought around a hare directly upon 


\section{A Sportsman}

him, which he reached out and killed. This was his first blood, and excited him to a high relish for the sport, and upon his next run he became the leader and after that one of the best and foremost in pursuit.

Many hare-coursing clubs exist in the State, which have annual prolonged meets on the levels of the San Joaquin Valley, which have prominent notice, and one would imagine from these meets so extensively attended, with the natural excitement following, that it was in reality, as it is, already a State sport.

For some years I have maintained a pack of these beautiful greyhounds, which have individualities seemingly equal to those of men. How one can help loving dogs I cannot imagine. The affection grows for them the more it is given opportunity, and there is no animal so near and dear to man as the dog. What affection he has! How affecting his earnestness and fidelity, his courage and intelligence! He cannot be debarred from heaven if there is any for us to obtain; for if we are to be happy there and have our wishes gratified, where will be the dogs we shall sigh for, companions of our happiest days on earth? Where will my dog Paris be?-my lovely red setter, who at two years of age took the first prize in field-working class at the Baltimore show, who attached himself to me for so many years and to no other; my companion in the field, in the boat for fishing, and who seemed heartbroken if I did not take him in my sailboat when I thought it was too rough for him. How quickly when I said "Sail" would he rush for my boat and curl up in it with tenacious right! How often would he go overboard in the lake, when his smooth feet slipped on the deck against his bracing poise, in sudden lee 
cant of fulness, for he would insist upon sniffing on the foredeck to windward! He could swim all day, ten miles or more if necessary and in the roughest sea, and I never felt any anxiety when he slid overboard; nor he, for he well knew I would round up in due season and scoop him up into the boat by the scruff of his neck, when he would seem to say, after his water shake, "All right, master, let's go on."

One day we had a tough time of it, and it made me smile to see Paris in his efforts to get aboard, when it was about all I could do to stay there. It was the only go-over of my boat which ever occurred in thirty years of sailing the lake, and quite my own fault, which I have always regretted in the loss of prestige with my family, from some of whom I had occasional suggestions of shipwreck, when the sky looked threatening at my time of going out, for there was little fun for me to go out in a kid-glove breeze. The particular day when the accident occurred was an unusual one, when some dark clouds were hanging about suspiciously, and I would not have gone out sailing under normal conditions. As the man said who was laying stone wall near the buckboard route as we were driving to the lake one day, where the stones were plentiful enough, and the wall was already of elephantine proportions, in answer to the inquiry of our driver why he was building more stone wall when already overstocked, "Oh, when I feel mad I go out and lay stone wall; that rests me!"

In somewhat of the spirit of the Berserker rage I felt impelled to go out. I knew that the conditions looked unusually stormy, somewhat in accord with my feelings. I know not why, for I had no cause for agita- 
tion, excepting a natural impellment to go out. My wife and daughter had gone out to the mouth of a brook two or three miles below, but could easily land beneath a shelter there, with their experienced guide, and I felt no anxiety about them. After getting out a mile or so, I saw a very suspicious-looking funnelshaped cloud coming toward me with unusual rapidity, and I saw I was in for it, though it somewhat disturbed my Berserker courage. I had time, however, to let down my catboat-rigged sail and put three reefs in it, and none too soon. Still I thought I might weather the severity of the squall, close-reefed as I was; but the first rush of the wind from the shore over the lake, accompanied by a torrent of rain, lashing the water surface to foam, indicated that I would be helpless, and as I held up my bow as well as I could, a sudden drop of wind, as it seemed to me falling from above, bore my boat beneath the water, but not deeply, for the craft, although carrying half a ton of ballast, had four air tanks below, sufficient to float her, and I had little idea of giving up the ship. The squall in its severity blew away everything movable, cushions, oars, and the small boat attached to the larger, for no small boat could have sustained itself in any manner, except sunken to a level with the water. My cap blowing away left my head unprotected, which suffered so from the flying water, pelting me as if I were in a hailstorm, being taken up as sand and small stones are in a gale, that I was obliged to tie my handkerchief over it, and my face had an appearance after the blow as if it had passed the night with a swarm of mosquitoes.

Poor Paris was at times blown far away from me despite his rapid swimming qualities, but would not de- 
sert me, although he could have taken a route for shore with comparative ease. At times he would be out of sight, and apparently engulfed by the waves, giving me much anxiety; but he bobbed up serene after the first. severity was over, but could gain no footing with me for some time, as my boat gave me a treadmill step, and it was with some difficulty that I could keep aboard of her against the wind and waves. Lying flat upon her side, and her stern higher than the bow, held down by the way-forward mast and sail, flat upon the water, the wind would bring around the stern, until the wind would catch in the sail, which, lifting and filling would turn the boat over on its opposite side. In this pleasant manœuvre the boat, water-logged, would sink bodily a few feet under water as the mast came up, falling flat on the opposite side, so I had nothing to do but keep step, and clear of the ropes, and wonder how long the play would continue. For a dozen times this continued, when, the squall abating, I had a comfortable resting-place on the side of the boat with my lovely Paris by my side.

The wind died away, and the sun came out bright and clear with many apologies for its previous disappearance. But dear Paris could not enjoy his pipe as I did, for he had never cultivated the habit. I had taken pains at the first outset, when I saw I was in for it, to tuck my pipe and water-proof pouch and matchbox down inside under my collar, and buttoned up my rubber coat at the neck, so that my tobacco was dry. My rubber coat would have been blown off me if I had not tied it closely around my waist with a small rope I had in my pocket, after losing the lower buttons, I would have lost them all but for the rope. 


\section{A Sportsman}

I have seen at sea a buttoned-up coat stripped completely from a man's back by the force of a gale. Despite my soaking and treading I did not get much wet above my armpits. In an hour after, sunning on my boat with my pipe under way, my wife came along in her rowboat, and Paris and I were soon snug at camp, and I experienced no ill-effects from the prolonged cold bath, although it occurred in the cold water of the spring, soon after the ice had gone out.

Poor Paris had the great intelligence so conspicuous in dogs, and well noted the preparations I made for departure from camp, when he would cling to my heels, and make strenuous efforts to get under my bed at night, and when let out, would haunt my door of egress. I had to explain the necessity of my going, and with a fond embrace leave him in a closed room, or he would swim the lake for miles after the boat. My keeper at camp would tell me how for days he would sit on the wharf of departure for my return, and no boat could touch in but what he was on the watch for me. When I would come, and I was sure to find him at the wharf, I would render myself as unobservable as possible until I landed, but if the breeze were favorable toward him he would know of my presence long before I landed, and plunge into the water to meet me. He was a very dignified dog and had little to do with other dogs, after the first round of scrutiny, when he would retire, and if approached by other dogs, would remove himself apart, but was the leader among the other dogs I had, over whom he seemed to consider he had to exercise a supervision.

One day I came up with my family, fetching a new dog belonging to my daughter, a somewhat 
solid fox terrier, Jack. As soon as he landed he pitched into an inoffensive dachshund of most peaceful disposition, whose cordial recognition of our arrival gave offence to Jack, and gave poor Polico a rough tumble before our interference could take place. Paris was a silent witness of the scene, which he evidently highly resented, and I remarked to my daughter that he would probably have something to say about it; and sure enough, for we had hardly gone into the house, leaving the dogs outside, when our ears were startled with a canine cry of great distress, and upon going out we saw Paris whirling Jack about himself after the manner of the revolving blades of a windmill in a brisk breeze. Our arrival was the signal for dropping, and poor Jack, dizzy from his rapid revolutions, and under the momentum of his discharge, accelerated by rapid locomotion, in whatever direction it might prove to be, brought up against the side of the house, the impact rebound of which threw him back several feet. Painful to him, but ludicrous to witness, and most salutary in effect. Polico was never more disturbed by Jack, and they became good friends. And with Paris soon after Jack settled down in pleasant relations, though for some days it was amusing to witness his fixed attention on that powerful machine which had given him a lesson in orbital revolution.

Poor Paris died of old age, as well as Jack, and they lie buried near each other, beneath a neighboring tree, and my daughter and I often ask for a few leaves or sprigs from that tree to be sent us when we are far away.

No wonder the heathen hunter, sought by zealous missionary for Christian heaven, on learning that his 


\section{A Sportsman}

dogs could not go there, said he did not want to gain it; or that the man experienced in life's disappointments while not loving his own kind less, said, "I find the longer I live the more I like dogs."

Jack was as faithful and devoted to my daughter as Paris to me, and the manner in which he would sit and regard her when she was occupied indicated that he considered her the most important being in existence. Fond as he was of boating, he would never go unless accompanied by his mistress, and when induced to take his place with Paris, in expectation of my daughter's going, he would tumble out with alacrity at the last moment on finding she was not going. Jack exhibited his great fondness for my daughter, as well as his dislike of my camp-keeper, from his taking him away to the kennel enclosure occasionally, when we were going off upon an excursion where we could not well take him, and evinced his dislike by always barking at him when he came near, with an occasional tug at the bottom of his trousers. We left him several winters at camp when going to California, though sometimes carrying him out with us. When left he had from necessity to make friends with Cushman, after mourning for some days for his mistress. During these periods of waiting he evinced much fondness for his keeper, who allowed him to sleep at the foot of his bed, and to accompany him on his boating trips; but as soon as my daughter returned, his hostility immediately appeared, and Cushman said it exhibited the basest ingratitude he ever witnessed. 
THE likes and dislikes of dogs are more evident than between men, without attempt at concealment. I have often noticed among my coursing greyhounds this feature. It is necessary in coupling for the chase to consider this, or all will not go smoothly. In the excitement of expectation, if the greyhounds are not well mated, they will fall foul of each other, and in feeding it is often necessary to separate them. If well mated they will advance to the field in unison, and a well-mated couple will work together with a good understanding, the one falling in rear, taking an immediate lead on the doubling hare, as never but a couple are freed on a single hare, nor but one hare run at a time.

It is amusing to see the intense interest taken by the dogs upon one entering the kennel area with the slips for coupling. How they close upon you, leaping over each other, and pressing alongside for the collar to be adjusted, which indicates an outing! These collars in pairs are connected with a short chain six inches in length, from which proceeds a leather slip of seven feet with a handle at the end for holding the couple of dogs; and strong it must be, for the impatient dogs when working the field, and witnessing the start of a hare when they are not to be released in pursuit, as another couple may have already been given the start, will pull along a man at his run, and if not well on guard, will sometimes pull away from him, though useless for overtaking the hare, connected as they are. The leather slips connections with the collars are hollow, having inside a stout cord which connects directly with the fastenings of each collar, which upon being pulled, instantly releases the two col- 


\section{A Sportsman}

lars, which fall off, and the two dogs are free for the pursuit.

Having a large grain field of several thousand acres on my place, enclosed about by a fence twelve miles in extent, where the land is pretty level, but rising on two sides moderately toward the centre, and where the opportunity of witnessing coursing is excellent, has led me to make many coursing excursions upon it, extending over a series of years. The plan followed is for the participators to pass in carriage or mounted along one of the roads, flanked upon each side, well at the head, by a man with a couple of greyhounds in leash. The dogs are alert and eager, with pricked-up ears and quick-turning heads, scanning about them for sight of hare. Their impetuousness is difficult to restrain, and no feeble or inexperienced hand should manage the slips, from which, collared, the dogs may break away together, or be too hastily freed.

A hare bounds suddenly at one side, from its form, and the nearest couple of dogs is instantly freed, and go off like arrows in pursuit. Perhaps the hare has a good start-five or six hundred feetand goes off in that bounding manner usual when disturbed by shepherd or farmer's dogs, a common occurrence, not enough to cause alarm, or even to give a dropping of the ears, which ply with motion. Interim those arrow-like forms are nearly approaching, and are coming on with before-unknown speed, and the hare, now warned by its projecting eyes, like those of the frog, which turn to the rear, redoubles his exertions with desperate efforts. But all in vain. The approach is faster than the running speed of a man if the hare was still. When the seizure is about to 
take place-for it is seldom that one dog makes it on the first run-the hare, nimble in the art of doubling, turns from hiscourse, to the rightorleft, while the leading pursuer, impelled by theimpetus of his greatestspeed, is carried on ahead, giving the hare a gain in distance. Herein comes the play of the second dog, one of which is likely to be in the rear, who then takes the lead in pursuit. The first dog has gained a point in turning the hare, and may, if of superior speed, overtake the second dog and again secure another point in turning the hare, and may perhaps make the kill, or secure all the points from his superiority, and there may be a dozen of hare doublings before the kill.

It would seem as if the greyhound were made especially for the outrunning of hare, so perfect is his build and adaptation, and it is a rare sport to see his pursuit of the fleet hare, which is immune in its speed against any other animal, though coyotes, which have great speed, though less than the greyhound, have been often observed running the hare in the same manner as followed by a pair of greyhounds. In two instances I have been present when a coyote was started up and soon brought to bay, for the greyhounds will take after anything that runs, excepting horses and cattle, and woe betide the farmer's dog straying across the field, with the hounds fresh on, especially in force, as we let them run loose together on the way home from coursing.

In fetching a coyote up, the greyhounds will tackle, and, if strong dogs, can hold until more dogs come up, which are liberated in such event, and together will wear the coyote out, receiving many wounds, 


\section{A Sportsman}

however, and in the two events I witnessed it was necessary to give the coyotes some final blows; for the coyote is a tough animal and most tenacious of life, and if full grown can put up a prolonged fight, and I have seen them when surrounded and bitten up for half an hour still give fight.

I have one in captivity, which was secured in his infancy by being dug out from his maternal home, and was brought up with a litter of collie dog puppies at the farmhouse, and evinced a most friendly and playful disposition.

The coyote's natural shyness was, however, shown in a degree over that of his puppy companions, although he would allow himself to be petted by those who gave him care and food. He was allowed to run about the farmhouse free with his young companions, but indicated a much keener appetite, and became somewhat of a nuisance in the dining-room, where he was allowed an occasional privilege. His disposition was very playful, and his gambols and pranks were most amusing.

As he grew older and larger he ran freely about with the collie dogs, and even rendered aid in driving the sheep about with them, and in one notable case, where a large flock were driven some twenty miles to another range, indicated considerable intelligence; but alas for confiding expectations! that very night upon arrival at the destination he signalized himself by visiting a neighboring ranch, and extinguished the life out of sixteen fat turkeys. Not being immediately detected as the destroyer he supplemented his exploit the following night by slaying nearly an additional score. 
This escapade led to his discovery, and his being chained up, as altogether a too expensive sheepherder, and his ignominious return was illustrated with a collar and chain and a free ride in the sheep wagon.

The natural taste for killing and fresh blood, and his great success in the turkey line, were unfortunate for our pet, for as the salmo salar fisherman returns with pleasure to the capture of the Fontinalis, so did Dingo yield to the attractions of the barnyard fowl at home; and thus forever closed the youthful episode of his free range, and since, with the brief intervals of breaking away from his moorings, he has polished the hard ground from a central stake over an area of some forty feet in width, as his bright chain well attests.

Adjacent, and sufficiently near for a hand-shaking, lives a large raccoon, similarly attired with collar and chain, and both are on friendly terms, excepting at feed time, when the experience of Jack, the 'coon, has induced him to insist upon having his meals served separately.

This system applies also to the dogs, including a bull-dog and stag-hound, which suffer injury if too intent upon the development of their sniffing qualities about the lunch counter, and the cry of distress which occasionally goes forth from the neighborhood of the cold meats is far more amusing to the looker-on than to the wailing canine musician.

In fact Dingo, now fully developed and most expert in battle, is ready for a scrap at all times. It is his great enjoyment and he exercises his ingenuity to get dogs within the fatal circle of his domain. He 


\section{A Sportsman}

will play with those who have the honor of his friendship, but woe betide any passing stray dogs, or those he is unfriendly with.

The passing strange dog, be he large or small, is sure to become the matrix of Dingo's cast, and may at exit well murmur the reminding words of Addison: "Nature formed me of her softest mold."

As a scrapper Dingo is the Jeffries of his arena, and will quit his food quickly for a rough and tumble, and although there are many dogs which could vanquish him, he has never yet encountered a canine of his mettle and power.

Almost invariably, when he has broken his chain, he has immediately celebrated his freedom by an assault upon some one of the collies, and, while several will join in mutual defence, he will by his rapidity and dexterous action clear the field in short order. He will then return to the kitchen door for larder filling, and allow himself to be secured.

He has never bitten any person. As to canine antagonists, he has often been seized at the back of his neck by fighting dogs, but invariably upon being so seized has turned his head with wonderful celerity, enabling him to seize the lower jaw of the attacking dog by a grip of his own, which seems to be very discouraging to the latter, judging by the instant hold-breaking.

Only once have we seen Dingo nonplused and distressed. This was on an occasion when, in a night foray, we had secured a very large female raccoon, which was secured alive by noosing out of an old hollow tree where she had a few young kittens, too young for saving. She was wild and ferocious, and had to be bound very securely. 
As Dingo was so ready and eager for scraps, the 'coon was brought out to him the following day and staked within easy limit, and when let go, flew for him, who was equally eager, and immediately followed an encounter of sanguinary ferocity difficult to describe. A 'coon, protected by its bountiful fur and rapidity of movement, is more than a match for any ordinary dog, and in weight-in this instance-was much more than Dingo's, but the latter was more alert than the 'coon, and provided with larger teeth and probable tenacity. Still, the 'coon was fighting for life and the loss of offspring, while Dingo was fighting simply for fun, and he soon obtained all he wanted, although no white feather existed among his holdings, and he worked himself up into a great fury.

It was soon apparent that it would be a long-drawn contest, and for fear that Dingo might in the end receive serious injury, which looked probable, he was withdrawn from reach, although desperately determined. That night the 'coon broke away, and has since been missing.

Dingo seems never quiet, and is always on the move about his arena, circling around incessantly, and, although having a house of rest and refuge, seems never to occupy it or to be found sleeping.

Often in the night his peculiar wild call breaks out in answer to other distant wild coyote calls, but if he breaks away by the breaking of his chain he is always found about again, and is secured.

The coyotes are the great pest of the sheep business, and our loss from them annually amounts, over a long period, to from 200 to 300 head, although 
recently, by having a remarkably clever hunter and trapper our losses are less.

We suffer correspondingly from adjoining town dogs, which are constantly shot at sight, and buried without monuments or head-stones. Signs are up warning against fetching on dogs, but the latter pay little heed to it and suffer in consequence. No matter how many coyotes are killed they never cease coming on, and sometimes four or five a week are destroyed.

They are especially plentiful at lambing time in March, and, although they will not then often attack full-grown sheep unless they are disabled and separated from the flocks, are particularly partial to young lambs. The mother will face about toward the coyote, and as soon as she is distracted off a little, the coyote will dash in and carry off the lamb. In the lambing season the ewes are gathered loosely about in selected localities, and herded night and day, when occasional fires are kept burning at night and lighted lanterns are hung about, which excite the suspicions of the coyote, as he is very wary and cunning, and if left to his own free action, will destroy six or a dozen lambs to one of his eating.

The coyotes can only be trapped by the exercise of great care, as they are more cunning and suspicious than foxes, but with trap and poisoned meat are tolerably well kept down, and are now of less damage than formerly.

Wild-cats, though quite scarce, will occasionally appear, and one cat will frequently kill a dozen lambs before being itself killed.

The great American bald eagle is also a destroyer of young lambs, but on appearance can generally be 
trapped by putting steel traps on elevated poles where the eagles alight to survey the situation, and, although they often get away with a lamb or two, are pretty sure to be trapped.

If undisturbed, they will do much injury upon a sheep ranch, especially at lambing time, when an eagle will easily carry off a lamb a few pounds in weight, and will often attack full-grown sheep, almost invariably striking the latter at the back or side of the neck.

Three golden eagles lately attacked-acting in concert-a small flock of separated sheep, and before the herder could drive them away succeeded in seriously wounding half a dozen, three of which died the same day, and the balance within a week afterwards, either from the direct wounds or the almost invariable blood poisoning which seems to follow when struck by the talons of the eagle.

The same result often occurs with human beings when struck by eagle talons, and two of our men in past years, when taking eagles from traps, were wounded, one through the hand and the other in the thigh, and both were many days under the care of a physician for treatment.

The one struck in the thigh had killed, as he supposed, a trapped bald-headed eagle, when his attention was drawn to the mate of the trapped one, which swooped upon him several times most dangerously; and while engaged in warding it off with his gun, he was hard struck by the dying eagle, which firmly imbedded its talons in his thigh, from which he could not disengage himself, and while so held succeeded in shooting the mate. 
Afterward he was compelled to cut off the striking eagle's leg and carry it so to town, where it was removed, and for a long time he was laid off from work, and under medical care.

There are three classes of eagles which attack sheep: the bald-headed, the large gray, and the golden, or black. The latter is smaller than the first two, stretching from wing tips about five feet, while the two first so stretch to an extent of from six to eight feet.

The attack first referred to was by three golden eagles together. The method of attack is to fly over the retreating sheep, and from a height of about thirty feet make a swoop down at the neck of the sheep, and repeat such attacks until the sheep falls over, when the eagle descends and makes quick work in rending for his ravenous apetite.

In this case of attack by the three eagles, their attacks were not confined to a single sheep, so that half a dozen were made victims, although the eagles by being followed and shot at by the herder failed to secure one for eating. One of the sheep which soon died had a large piece of flesh and skin torn from its neck down to the shoulder blade and its jugular vein cut, and quickly bled to death. The eagles flew away, upon being disturbed, to some neighboring trees, but were too wary to allow approach for shooting. The herder, however, being supplied with medicine pills, i. e. strychnine, of potent power for eagles, dogs, and coyotes-one half grain for the first, one grain for the second, and two grains for the third-soon had a large hare killed, which he cut up into numerous savory portions, all liberally impregnated with destructive 
stimulants, which he exposed at a favorable place, and removed himself to a considerable distance where he could observe the scene. This would have been a useless effort for the bald-headed or gray eagles, which are not known to return to feed a second time upon a carcass once fed upon, or when disturbed in feeding, but the golden or black eagles will return, and are often poisoned or trapped from returning. In this instance, after some time had elapsed, the three eagles that had occasioned so much destruction were seen to alight, one after the other, at the poisoned meat, which was all consumed by them.

After this, and their circling about in the sky, one was observed to fall to the ground, and was found dead, while the others disappeared in the distance and were not seen afterwards, and undoubtedly died from the poison.

While animals have a particularly keen sense of smell, birds are much lacking in this respect, and would seem often to be entirely without it, and the cunning crow is easily deceived by whisky-soaked corn, and becomes so senseless as to be caught by hand, and all kinds of birds are easily poisoned by strychnined grain.

But birds make up for this deficiency by an apparently abnormal keenness of sight, as witnessed particularly in the buzzards, which, flying at a great height - so high as to be invisible to human sight, - -are speedily attracted by an exposed dead animal, even in a rocky field, where surrounding objects bear some resemblance to the dead animal.

The eagle and hawk are very expert on the wing, and the hawk lives largely upon birds of quick motion, 
caught on the wing in the open, where they cannot gain the shelter of trees or bushes.

The eagle is often observed swooping upon the fish-hawk, carrying off its prey in mid-air, frightening the latter to drop its burden, and catching the coveted prize before it falls to the ground.

Our herders have often observed the eagle chasing a hare in the open fields, and catching it in its clutches despite its rapid doublings which so often trick an overtaking greyhound, and often while chasing on the doublings will strike over the hare senseless with a wing blow.

It has been amusing to witness the eagle chasing a hare which has gained a fence line for protection, passing through the line from side to side more rapidly than the eagle can shift over, by which the hare has been seen to follow a fence line for a mile or so, and consume an hour of time, before a favoring clump of bushes, or trees, or brush heap afforded safe shelter.

Since writing the above, I have received notice of two more sheep being killed by eagles, which have been unusually plentiful this season, and we have lately killed about fifteen.

The coyotes have also been plentiful, and of late we have averaged, poisoning and trapping, five or six a month; and despite their plentifulness, we have suffered but lightly from them, owing to the watchfulness of the herders, and now that the lambing season has commenced from about seven thousand ewes, we give particular care.

This region on the foothills of the mountains, twenty miles north from Sacramento, so mild and pleasant in winter and free from ice and snow, is one 
where myriads of birds congregate from the inclement regions north - in fact, one where citrus products are grown in perfection, and where deciduous fruits are ripened earlier than elsewhere in the United States, and early peaches and cherries are forwarded to Eastern markets from about here in May.

Thousands of robins, larks, doves, quail, blackbirds, linnets, sparrows, and an endless variety of small birds abound, large numbers of which remain through the year.

The quail, all of the large mountain variety with head plumes, do not lie very well to the dog, and fly very swiftly, but fall readily enough to the quick shot.

Duck and geese are also plentiful, and the latter have to be more or less herded off the grain fields in winter, where they alight often in large numbers, and if not disturbed will destroy many acres of growing grain by feeding on and pulling out the young sprouts.

I often take my greyhounds, coupled without slips, to accompany me when driving or riding, which they enjoy very much, and give pleasure in the contemplation. They will, however, diverge occasionally for a speeding hare, which they cannot overtake when coupled, and will soon return from, and pay no attention to a flock of sheep while passing through or by them while observed; but let them once get out of sight with an intervening hill, or far in the rear, near a flock of sheep, and they will go for them as wild wolves might, and if not interfered with will mutilate dozens of them in short time. And think of Jack, my daughter's gentle fox terrier, who fell back with the greyhounds 
one day when they were coupled, as usual, and who lagged so that I went back with suspicions of mischief and found Jack as busy as any, holding down a large ewe, which he was evidently exerting himself to disembowel. I gave all big whacks with my stout stick, and knocked Jack senseless with a blow on the head, which I terribly regretted, as I thought I had killed him. But he revived after some time, and when I got the dogs back to the carriage, where my wife and daughter were, I observed that Jack seemed rather groggy, and lifted him for his mistress to carry, remarking that he appeared exhausted with his run. Jack never mentioned the occurrence, nor did I to my daughter until some time afterwards, when she forgave me, since Jack appeared as lively as ever.

One of my greyhounds, and one of the fleetest, was so beautiful, graceful and affectionate, that we made a house dog of her, Penelope by name, whose poses by the fireside were pictures of elegance, and we were all very proud of her, seemingly such a perfection of gentleness and intelligence. She had the full run of the premises, and never seemed to stray off far. One day a shepherd reported that she had made her appearance in the early morning among his flock of lambs and killed eight or ten of them. We considered this very improbable, although his description of the killing dog, which he was not able to get a shot at, corresponded to that of Penelope. I interviewed her upon the subject, but one glance of her gentle, loving eye dissipated any suspicions which had been aroused, and I told the shepherd he must have been mistaken, and that he must get his gun work in on the next killing. When I arose the next morning I found the shepherd waiting for me, 
saying eleven more lambs had been killed during the past night and in the early morning, and that he was unable to get a shot at the killing dog, but had distinctly traced it to my house, and that dog, lying now so peacefully by the fire, was the one. Could it be possible? I examined Penelope, and alas! on her breast in several places were blood marks scarcely yet dried, as well as woolly shreds, which too plainly indicated her guilt. Penelope again denied the accusation with outstretched paws and reproachful glance, but had afterwards to be relegated to the kennel enclosure.

Another performance of Penelope had occurred, which certainly exhibited a reasoning power which we had overlooked, from its ingenuity and amusing character, of slight importance compared with lamb killing. Having the free range of the house, she discovered that the dinner table had a bread roll, wrapped about by a napkin, adjoining each dinner plate-a tempting morsel for her-and during the desertion of the dining and adjoining sitting room she availed herself of the opportunity of taking one of the rolls-just one each day, and no more. The regular shortage of a roll each day at dinner occasioned remark, to which the butler asserted that he regularly supplied the full complement. This occurring so repeatedly gave some wonderment at the mysterious disappearance of a single roll each day, as all asserted, each of us, we were not the cause. This brought it up to the butler, who put himself, concealed, one day before dinner, where he could view the table, and was much surprised to detect Penelope in the act (when she supposed the coast was clear) of deftly removing one of the rolls, which she carried into an adjoining room, and quickly, as she 


\section{A Sportsman}

supposed, destroyed all evidence, and then resumed her pensive and innocent attitude in front of the open fire, her favorite resting place.

While town and farmers' dogs of all kinds will attack, mutilate and prey upon sheep, even their supposed best friend, the collie, brought up with them, will do the same thing-not with his master's own flock, which he will guide and protect with his life, but the sheep belonging to a neighbor, which the collie evidently considers beyond the pale of his protection. This is a fact well known to sheepmen, and denotes the inborn tendency towards destructive inclinations born in so many animals - and by no means lacking in the superior man, who has this inclination largely developed, however guarded it may be by reasoning - as indicated by the collie dog in selecting a foreign flock of sheep for his blood-craving taste, without sacrifice of his home loyalty.

And who shall say that animals are devoid of reasoning powers, or that dogs and the most intelligent animals are wanting in this respect? Admitting that such is a fact, it is for consideration if (in the inevitable progress of evolution, which, by the laws of nature, is irresistible) it is not reasonable to believe that advancement may be made in developing that sense, as indicated in the superior animal, man, whose source may have been at some period more obscure than shown at the present time by the inferior animals. The period of man's evolution must have been very long, consuming, possibly, many hundreds of centuries, and it is only within a very few thousand years that he reached the level of intelligence requisite for him to mark rough hieroglyphics upon the face of time. But he 
was endowed with remarkable physical advantages over any other existing animals, particularly in the essential of speech, and in the flexible arm and hand, without which his inferiority, compared with his present position, would be most striking. Added to this his long life, surpassing that of others, gave ample opportunity for the storing of experience and its transmission largely to succeeding generations.

And the all-important, animated element of soul, an existence of intelligence and reason,- - by what adducible evidence shall it be denied to other intelligent animals?

The dog has been the companion of man from the earliest historical records, and probably long before, and has in that experience gained advantages not allotted to other dumb animals, and, despite his want of articulatory organs, fully understands many words addressed to him in various languages, and if he had the power of speech would certainly respond in answer, so that his failure to do so is wholly from a physical defect.

I have witnessed many remarkable instances of his: intelligence, and I am reminded particularly of the extraordinary ability of the dog Bozzie, a collie that belonged to Mr. Clason, of Chicago. The owner-a gentleman of position and character-has given much attention to breeding collies of superior intelligence, and had in Bozzie one of such surprising ability that one can hardly credit the results. This dog, bred from a line most intelligent, exhibited in puppyhood such remarkable docility and alertness that her owner gave particularly patient teaching, resulting in marvellous feats which would make one doubt his own senses. 


\section{A Sportsman}

Bozzie was familiar with the alphabet and numerals, and would spell out correctly almost any simple words, and many of two syllables, and do simple sums in addition, subtraction and division, beyond the possibility of trickery, and while her master is out of her presence. Being given, say, the number of seven, for instance, to add two and deduct three, Bozzie immediately gives six barks; and how much are five and three? when eight barks are quickly given; divide ten by two, and five barks are returned. The element of telepathy or mind-reading is now a subject of scientific inquiry, and a controversy is now going on concerning it in some of the newspapers. Bozzie appears to be an adept in this particular, and if a number is written on a piece of paper-not to her master but concealed by the writer-she will immediately give the number of barks.

Mr. Clason some time ago dined by invitation with President Roosevelt at Washington and was accompanied by Bozzie, who excited the wonderment of the Roosevelt family by giving the ages of the President's children, by barks, correctly, upon being asked by each in turn, the questioners being instructed to keep mentally in mind their particular ages. This would seem incredible were it not vouched for by witnesses. She would count, and give readily in barks, the number of persons present with her. One sceptic gave her as follows: Multiply two by five, then divide the amount by two, adding three and subtracting six, whereon Bozzie immediately gave two barks; and another the following: Divide eight by two, and this half by two, and the result again divide by two. Bozzie immediately gave one bark. And many other sums of a 
similar character, to which the answers were correctly given, as well as the correct spelling of many words of one and two syllables. This seems incredible, but is said to be well vouched for.

If this does not indicate intelligent reasoning, it would be difficult to say what it is that directs the dog's mind; and I believe in my own mind, that if intelligent dogs could be endowed by the power of speech, and longevity equal to man's, and have the flexible hand of man, which is an immensely valuable feature, they could be instructed as children are in language, reading, and writing, and in consequent evolution take rank above many of the degraded tribes of men who are accounted the possessors of immortal souls, which are by assumption denied to all the animals lower than man.

Since I have written the above about Bozzie, I learn from correspondence with Mr. Clason that she has departed from earthly life, and that one of her descendants, Tess, now two years old, is almost equal in intelligence and action with her mother, and that a still younger offspring, one year old, Bozzie III., is exhibiting an intelligence which the owner thinks exceeds that of any of her race.

Now come the accounts of the wonderful horse, Hans, at Berlin, Germany, which is exciting much comment and scientific examination by experts, and whose picture has appeared in several illustrated journals of prominence. It is stated that this horse counts readily up to one hundred, and will indicate a number correctly below that, by striking the floor with one of his front feet, and will do sums in arithmetic in complex numbers, and in fractions. It seems almost, if not quite, incredible. 
This Hans, a Russian stallion nine years old, jet black in color, with bright eyes, and small, expressive ears, which seem to act in responsiveness to his actions and attentiveness, has never been touched by a whip, and is as human in gentleness and affection with his owner and master as an animal could be, is rewarded for his intelligence simply by a judicious giving of carrots, of which he is very fond. He has never been publicly exhibited by his enthusiastic owner and instructor, Herr Von Osten. Being given the name of the day, say Wednesday, he will readily strike four times with his right foot, for the day of the week, and being told that it is the twentieth day of the month, and being asked what day of the month it will be a week afterwards, will strike twenty-seven times. From half a dozen pieces of cloth or paper of various colors, he will pick out and designate any particular one named by color. It is a simple feat for him to give the correct result of adding several simple numbers together. He will give immediate answers to questions of how many times six will go into thirty, and what number of times six will go into eighteen, and what is the seventh part of thirty-five, and the answer of similar sums, of adding two numbers together, say four and five, and deducting six. And in vulgar and decimal fractions he seems quite at home, as in questions of this character, and will answer how much must you deduct from four to obtain one and three-twelfths, giving first the whole number of two, and afterwards nine strokes for twelfths. This and many other arithmetic sums too numerous to mention.

Had not Hans been submitted to the most critical examinations by scientific savants-the last being a 
committee of Professor Haeckel, the most eminent biologist and critical expert known, Professor Stumpff of the Berlin University, and Professor Norenburg of the Prussian Ministry of Education, who coincided with all of the distinguished committees of examinations, that Hans clearly exhibited thoughtful and reasoning powers, with remarkable memory-one might well doubt the statements made, and believe that Hans simply followed a fixed routine, or resorted to signs and aid from his master, but has proved to be entirely independent of him; and to pass the ordeal of examination as triumphantly during the absence of his master as when he was present, clearly demonstrating that he understood the German language when addressed to him, and in no way depended upon the aid of any trickery or drilled memory.

And if all intelligent and reasoning animals have the element of soul-and who can tangibly deny-where shall we draw the line? When we view the starry sky and observe the many millions of suns, many eclipsing our own in magnitude, and by analogy having their subordinate satellites as ours, and actually showing them in a few instances, as that of Sirius and Procian, and by the spectroscope and prism showing such as have almost identically the elements of our sun and its planets, may it not be a reasonable conjecture that there may be countless worlds similar at least to our own in having elements favorable to animal and plant life? If it be so, and none can deny, may there not be many worlds possessing beings of intelligence and soul, possibly far in advance of those upon our habitation, created by the immutable laws of nature which have created ours? And beyond our universe, in endless 
space, are seen, by telescopes of the greatest power, faint glimmerings of nebulas, which may yet be resolved by increasing powers into universes as immense as ours, from which light moving with the velocity of electricity, sufficiently rapid to circle our earth seven times in a second, would require hundreds of years of time to reach our world. And beyond those glimmering lights in endless space, What? We cannot affirm, and we cannot deny. We cannot solve the mysteries of nature; nor can we deny the Almighty power of creation in extent.

Light, which arrives in eight minutes through the space of ninety-three millions of miles from the sun, and an hour from the most distant planet of our solar system, Neptune, which requires hundreds of years to make its orbital journey around the sun, which our earth completes in one, requires two or three years to reach us from the nearest fixed star in the sky, and if we could direct a new light from our earth or an electric message into space, it could only, in a hundred millions of years, have just commenced its journey through endless space, upon a route which would be illimitable.

How little we know of anything beyond our immediate reach! Of even our companion planets, or even of the moon our satellite, but a few thousand miles distant, whose features our scientists are not all agreed upon, and yet in our conceit we determine, without logical evidence, the distinctiveness of intelligence, reason, mind, and soul. We, the superior animals, are progressng from the identical natural source from which all living creatures have emanated and progressed under the immutable laws of nature. 
CALIFORNIA is conspicuous for its variety of $\cup$ fishes, in its streams which abound with distinctive kinds of trout, and in the Pacific waters which lie along the coast, where an endless variety of game fishes are to be found.

It is somewhat annoying for the many lovers of the eastern trout to be informed that our eastern trout, technically speaking, are not trout at all, but charrs, and that the true trout must be sought for on the Pacific Coast, simply because it sheds its teeth from the vomer, which is the middle part of the roof of its mouth, as does the salmon, while the true trout in the form of its vomer differs from the charr, and preserves its teeth through life. For this slight difference the ichthyologists have seen fit to designate our eastern trout as charr. It is natural that when the first settlers in America, familiar with the English trout (Salmo Fario), finding the carminespotted and brilliant-hued fishes with high game qualities, called them trout, though far more beautiful than the English, or those of German or Northern European regions, which are true trout in the scientific sense.

Our eastern and central trout are correctly the Salvelinus Fontinalis. It is considered by the most eminent authorities that the various trouts of the northern Pacific streams, the rainbow, cut-throat, steel-head and golden, all true trout, have descended from the socalled steel-heads, as well as the various lake trouts, the latter being similar to those of our eastern and central lakes, of dull color and brown spots.

The steel-heads (Salmo Gairdineri), found in the various streams of the northern Pacific, take 


\section{A Sportsman}

readily to salt water, as well as charr, and reach a maximum weight of twenty-five pounds and over, and are of high game qualities, and readily take the fly, as well as fresh bait. They are speared in large numbers in some streams in the autumn, as they come in from the sea. The designation of steel-heads has been given from the lustrous steel coloring of the heads. Otherwise this trout is dull in color with brown spots.

At the Carmelo stream below Monterey Bay they come in largely with the raising of the water from the autumnal rains, where they breed extensively, returning to the sea before the spring freshets are over. This stream exhibits the peculiarity late in the spring of clogging up its outlet to the sea in low water by an accumulative sand bank, through which the water seeps, making an entrance impassable for the passage of fish. Down in the stretches of pools so confined the young steel-heads are plentifully found of one and two years old, weighing from a quarter to half a pound, which afford good fly fishing. These young trout go out on the first rise of water, and grow rapidly in the sea. It is not uncommon when the first rains come, when the rise of the stream has not become sufficient to break the barrier of sand at the outlet, to see the steel-heads seeking a passage through the shallow water, and at times throw themselves bodily out on the sand in their eagerness to get through; and when the water rises sufficient for passage, though still shallow, the spearers take their stand and secure sometimes large quantities of the trout by this barbarous method. The incident of throwing themselves out of the water on the sand where fresh water percolates through the bank is also observed with salmon on the Pacific, 
showing the strong impulse of nature in this respect with the Salmo family, which must gain fresh water to renew its species. I have often observed in eastern waters the struggling efforts of trout to get through the shallow reaches of water over sand banks at the mouth of streams, and often observed trout working through when compelled to forward themselves on their sides, and have dug channels through the sands to facilitate their passage.

The steel-head trouts are very plentiful on the Pacific coast, particularly at the northern rivers, where they ascend plentifully with the salmon at the spawning season. They are the largest trout known, perhaps being disputed in this respect by the cut-throat trout (Salmo Mykess), in Lake Tahoe between the States of California and Nevada, where they attain their largest size.

The designation of cut-throat is given to this trout from its having a crimson or scarlet coloring on the membrane between the branches of the lower jaw. It is, perhaps, more extensively distributed over a large area than any other, though its markings to a considerable extent are influenced by its local surroundings. It is plentiful in the north Pacific streams of Kamtschatka, Alaska, Washington, Oregon, northern California, and in the streams on both sides of the Rocky Mountains, and in the Utah basin, and in Colorado, and more southern idstricts. The steel-heads are not, however, esteemed so highly for food as the other trout, though very gamey.

The rainbow trout (Iridius), a favorite in the California streams, is a plump silvery-bluish-colored fish with red lateral streaks. Structurally it is claimed to 


\section{A Sportsman}

be dentical with the steel-heads, and it is claimed that when given access to the sea, its colors are changed more or less in conformity with the former, and a question exists which may have been the original parent of the other. In fact no fishes exhibit the characteristics of rapid change of colors, as affected by surroundings, like the trout.

The golden trout, lately brought to notice, taken from a central California stream, is conspicuous for its bright golden color, and by some is claimed to be of a distinctive genus. I have not seen it, and its classification will of course depend upon its structural formation, and not likely to be a new one, and will likely be classified with other known trout in the State, and possibly with the charr, Dolly Varden, which approaches more than any other on the Pacific in its gamy qualities to the eastern trout.

A charr (Salvelinus Malma) is also found on the Pacific Coast, a red-spotted, gamy fish, and a ready fly taker, known as the Dolly Varden. It is of gaudy color and a favorite, and although a charr, has been officially classified from the Smithsonian Institution of Washington in this instance as the Dolly Varden trout, and will so remain, charr as it is.

This impulse of nature with the Salmo family to seek fresh water for spawning is pursued to a most extraordinary extent, and is fatal to millions of salmon annually on the Pacific Coast, while trout of less bulk, and adaptive agility, have slight loss in this particular.

The salmon, however, not satisfied with reaching water sparkling with vitalizing life, pushes on as if impelled with necessitated urgency, as far as the stream extends, or until its strength is exhausted, for- 
tunate or not, as it may prove, if it escapes the seines and revolving catch wheels of the canners, or the spears of the Indians, or the foray of wild animals which depend upon it for nourishment through many months of the year. In that mad rush of advance impelled by mutual desire, the salty waves at the estuaries of the streams are often incarnadined with the ruddy life blood from moving masses of salmon, set free by the propeller blades or revolving wheels of passing steamers; and, incredible as it may seem, these schools of moving salmon are at times so compressed across the surface of streams, near the outlets, as to hide the water from view, and if they could be so held, sustainable for foot passage, one could cross from one side of the stream to the other without wetting his feet. I have a picture of a pack of this character, taken on an Alaska stream.

Upon the salmon entering fresh-water streams its first movements are in leisurely swimming about as if in enjoyment of the change of water; and at nightfor it is a nocturnal fish as are all of the Salmo species -it commences its up-stream journey, which seldom exceeds two or three miles an hour, and on it goes upon its death excursion, as almost invariably experienced in the principal long Pacific rivers. In the Columbia River it ascends to the Spokane Falls from six to eight hundred miles, and in the Sacramento River four hundred miles, and up the San Joaquin River to the extent of its tributaries, some hundreds of miles, when they all, at least all of those which reach the upper waters, never return, and countless millions in ages past have thus perished, and will doubtless continue to do so.

During this ascent, in the fresh-water stream, 
the salmon constantly deteriorates in quality, strength, color and form, as it receives no nourishment from food whatever, and the occasional incidents of its taking spawn, or a baited hook, have no bearing on its status.

As they get on, their silvery hues, so conspicuous in the sea, fade away, and their flesh likewise loses its bright pink color, and its blood pales steadily, and those which reach the higher waters arrive in such a wretched condition that it may be doubted if many of them are fitted for the last act in the drama of the salmon, of emitting the spawn of reproduction.

I have personally witnessed the condition and situation of these worn-out salmon, stranded in the upper waters of the San Joaquin River, stagnant with the decay of dead fish, where those surviving, mutilated from bruises, with worn fins and tails, and half blind, were listlessly swimming about in hopeless search for outlet. The banks of the pools were in places white with salmon bones and skins left by devouring animals, which had no difficulty in securing their prey, and attested by well-worn paths along the shores. Even the Indians spear such fish for food, patched with white fungus, and emaciated to the last degree. Salmon in this condition are in such a contrast with fresh runs that one can hardly recognize them. The jaws of the males grow longer and hooked at the ends, the back becomes humpy, and the scales disappear, and the belly shrinks away and becomes dark in color, and the stomach, so long disused, will be found shrunken away to the size of a man's thumb. It would not be possible for salmon in this condition under the most favorable situation to ever reach a state equal to the original. Salmon only partially 
damaged, which find their way down to the salt water again from spawning beds but moderately distant from the sea, may possibly recover to a primitive condition; but I very much doubt it if their stay from the sea has been prolonged, for the inevitable result of stomach shrinkage is bound to occur, and an almost complete extinction of the stomach glands (pyloric cœea) and of auxiliary internal organs.

Salmon fly fishermen are familiar with the black salmon which are found in Atlantic stream pools, which occasionally take the fly, having come down from the upper waters and mingled with the fresh runs. These are the salmon which have lain over a year in the stream, and are more or less blind, but have, some of them, sufficient vision to see and take the fly. These we know to be completely worthless for food, and they are thrown away, and if examined internally will be found to be almost deficient in stomach and stomach glands, and we may feel rather sure that they can never be revived to a good form again.

But as to those salmon, male and female, which return to the sea from short streams the same season after spawning is over, it may be that they will recuperate to a good condition again. But it may be a question if they do, although we have no certain evidence of it.

It might be cited that almost all of the enormously large salmon which have been taken, weighing from sixty to even one hundred pounds, have been marked almost invariably by some prominent features, especially in hooked jaws. From the large salmon I have seen, and the many casts in museums and other places, and particularly in the large collection of salmon casts made by the late Frank Buckland, of London, and in 
the extensive collection of salmon casts shown at the great fisheries exhibition in London some twenty years ago, which was a marvel of its kind, I observed that the casts of all the large salmon were marked by the distortions of the maxillaries as shown in the fresh-water spawning life, with the lower jaw extended and hooked.

Among the millions taken of the quinnat, or king salmon, in Oregon, at the Columbia River canning works, an occasional one, but very rarely, has been taken weighing up to one hundred pounds, and one frozen in ice, of eighty-two pounds, was sent on to the Columbian Exposition. As these large salmon are almost invariably males, the question arises if they had experienced the vicissitudes of river and spawning life, and were not survivors by some singular occurrence of incidents, and had missed the usual predestinated fate of salmon.

The warfare which goes on between the males at the spawning beds, for the favorable consideration and possession of the attractive mistress of the spawning domain, are often severe in results, often causing the death of the defeated. When commenced between two males, such combat continues until the complete defeat of one, when the conqueror is left in possession, until disputed again by a fresh arrival. As the males seem to predominate over the females, it can be believed that a champion male of good record must have a strenuous experience. In consequence of these conflicts, most of the males show the results, in loss of fins and portions of the tails and other mutilations; for the muscular powers of the salmon's jaws are great, upon which the fish depends 
for all the mastication its food receives, and its seizure of small fish is confined to those which can be readily swallowed whole. The hooked jaws of the large salmon do not necessarily show that the possessors have had a river spawning experience, for the hooked formation is an accompaniment of age, as shown with trout.

From the fact that the extra large salmon, of which I have seen many casts, have not shown loss of fins, or parts of tails, or have exhibited other mutilations, such would seem to have escaped the river spawning experiences, unless the bone rays of the fins and tails have not by the process of nature been renewed. This is rather improbable, and tends to the opinion that these large salmon have escaped the river experience, so fatal to those of northern Pacific waters; which critical application would not apply to the salmon inhabiting the shorter European streams, from which undoubtedly many salmon return to the sea after spawning season, of which data is not at hand for consideration. But that the northern rivers of the Pacific on the American coast, as well as those of the opposite Asian Kamtchatka waters where the salmon abound most plentifully, all, or almost entirely all, terminate most ingloriously their lives in the fatal season of reproduction, is clearly indicated.

That the salmon of the Pacific Coast, in a commercial sense, is far more valuable than all the rest of the Pacific fishes combined, or of all the salmon availed of elsewhere in the world, is indisputable. They abound in such numbers as to give the canners from California to Alaska a product of world-wide prominence. The humble and unambitious codfish must not be overlooked as of future great importance to 
the Pacific Coast, since those familiar with the subject say that the codfish grounds of the northern Pacific are as prolific and non-exhaustible as those of the banks of Newfoundland. In this connection with fishes as a food product of the future, I am reminded of the able report on the North Sea Fisheries, read at the great Fisheries Exhibition in London, in which it was stated that, despite the greatly increased population of Europe, and the increasing consumption of fish, owing to the ready distribution of fresh fish by railroads, that the North Sea, which is the prominent European field of supply, was estimated to be able to furnish for consumption from three to five times the present demand, without likelihood of any noticeable exhaustion. This is cheerful information for those who are puzzling their brains with a fear of a demonstration of the Malthusian theory of overpopulation, which, at the present rate of increase of population the world over, is proceeding at a ratio which cannot long be sustained; still we have a good leeway, and until a thousand millions of human beings dominate the North American continent, and an equal number the Southern, and as many more in Africa, and a thousand million or so more for the open situations of the world, we need not have apprehension, and we may reflect that the salt ocean alone could supply without exhaustion, at the present time, a weight of production equal to that daily consumed of various products by the human race.

Of the Salmonidae and its several genera found in the temperate and Arctic regions, the salmon is the most interesting and plentiful, and schools in the north Pacific in immense numbers, extending 
down half way along the eight hundred miles of the California coast. The annual pack from California to Alaska represents an average of about eleven hundred thousand cases of forty-eight pounds to the case, and as three salmon on the average are required for a case, the number of salmon annually canned would amount to between three and four millions. The consumption does not seem yet to diminish seriously the supply, though the number packed varies considerably, sometimes running down to seven or eight hundred thousand cases and up to a million and three quarters of cases.

Little progress has been made on the Pacific Coast in artificial propagation; although the ova or eggs of the salmon are detached and free at exudation, as with all the Salmo genera, there does not seem to have been any very successful artificial breeding of the salmon anywhere, despite all assertions to the contrary. In fact in Canada, where for years the artificial breeding of salmon has been pursued, it is claimed that no material advantages have been gained, and the subject is now one of controversy between two prominent fish culturists-Mr. Samuels, of Boston, in the affirmative and W. H. Venning, of Ontario, in the negative-and as Mr. Venning has been for many years a commissioner of the Canadian fisheries, his arguments seem well supported, and his experience would seem to have much weight.

Yet the importance of this subject is too great to be hastily summed up, and while the weight of evidence has been largely with Venning, that more lately given by Samuels, including the results obtained from the superintendents of half a dozen Canadian 
streams, covering a period of several years, indicates that the hatching out and increase of salmon at the several streams has been decidedly favorable.

The success of artificial propagation of ova from a large variety of fishes has been so successfully indicated that it would be most unfortunate if that of the monarch of all fish, from a fisherman's point of view, should fail; and the apparent diminution of salmon, where hatching works have been established, is believed by some familiar with the subject to have occurred more from the persistence with which the seining of salmon has been followed, than from a failure in the artificial propagation.

It is estimated that less than four per cent. of the ova naturally distributed by the female salmon is hatched out to successful life, owing to the various adverse conditions which surround the fish during its young life, while seventy-five per cent. of the impregnated eggs are hatched under the careful attention bestowed at the hatcheries. The amount of ripe ova found in a matured salmon spawner is often of the weight of three or four pounds.

Experience has shown that the liberation in free water of the freshly hatched salmon is almost invariably fatal to its life, as it steadily falls a victim to other fish and the variety of water feeders which destroy it. If retained in proper receptacles, however, and properly fed until it is five or six inches in length, it is found to take good care of itself and have favorable prospects of reaching maturity.

The salmon of the Pacific, singular to say, do not take the artificial fly so readily taken by those of the Atlantic. They will take it if trolled under 
water when they are feeding, as they would a spoon or even a rag, as they will any small object moving from, or by them, and I have several times, when trolling for them with fresh fish bait, had my leaden sinkers taken off by them.

Among the Pacific salmon there are five varieties, classified one hundred and fifty years ago under the head of Oncorhynchus, by Steller, an eminent Russian scientist, which designation has abided.

These salmon are distinct from the Atlantic salmon (Salmo Salar) in some minor particulars. The Pacific salmon has from fourteen to twenty bone rays in the anal fin, to nine or ten in the Atlantic. It has more gill rakers, larger scales, and has more or less of brown spots about the head and back. It has the usual silver white color, but at the head a peculiar lustrous steel color, as one might suppose to come from burnishing a metal of mixed lead and silver, a pale olive cast peculiar to this fish. This description applies to the principal salmon, the Chinook or king salmon so plentiful, and more extensively used in canning than any other. This salmon at the Columbia River has an average weight of twenty-one pounds, while the same fish from the Sacramento River averages from sixteen to seventeen pounds.

Of the four remaining Pacific salmon the blue-back (O. Onerka) is the next important for canning, moderate in size, averaging from five to eight pounds, being of red color and good flavor. This salmon is prominent at the Fraser and Yukon rivers, and ascends to the limit of those streams, and is domesticated more or less in Lake Whatcom, hundreds of miles from the sea in Washington, where it is always 
found, though diminished in size and less attractive in form and flavor then when fresh from the sea. When young it has a few black spots, which disappear later on.

The silver salmon (O.Kisutch) is still smaller than the blue-back, weighing from three to eight pounds, of good flavor when fresh from the sea, but not accounted of value in canning.

The dog salmon $(O$. Keta) averages about twelve pounds in weight, frequenting the northern rivers, and is worthless for canning or consumption, though eaten by the Indians, who are not at all particular about the character of their food. It is of a dull silver color, with small black spots, and as it advances in age its jaws grow much out of regular line.

The last variety of salmon is the humpback $(O$. gorbuscha), the smallest species of all the salmon, weighing from three to six pounds, of bluish silver color, with plentiful small black spots. Its back is more or less humped, from which the name is given. Its meat is of inferior quality and, with the dog salmon, it does not make the spring run up the northern streams; and, small as it is, becomes more distorted in form and jaws than the dog salmon. Both of these are moderate in extending up the streams, and are noted for their peculiarity of locating for spawning in very shallow water, where they often become stranded and readily fall captive to the Indians and wild animals. 
THE salmon for canning are taken principally in seining, although in late years large water-wheels have been erected in favorable places on river banks where the currents are rapid and where salmon run, which, revolving by the currents, take up at times large quantities of the salmon heading up stream, and in some instances have scooped up immense numbers, which by an arrangement of the wheel slide into an adjoining compartment, and catches of a single night have been made of a number of tons in weight. Spearing by the Indians and scooping up with large hand nets are also followed to a large extent.

Most sportsmen will agree that, tempered with experience and surroundings, they have a favoring, between fishing and shooting, for one over the other; commencing with the extremity of boyish enthusiasm in the catching of minnows and small fish, and the knocking over of sparrows, they advance in more fixed preferences. I will own that, although I have had some experience in the shooting line, my preference is for fishing, which I have followed more assiduously than shooting.

In $\mathrm{r} 89_{2}$, in the month of June, when at Monterey on the California coast, a hundred miles south of San Francisco, and visiting the hauls of the market fishermen, as brought in principally by Italians and Portuguese, I was interested in observing more or less salmon brought in, which had been taken with baited hooks on strong cotton handlines. This interested me so much that I accompanied some of the boats which left at an early daylight hour, and as a school of salmon had come into the bay, I saw a number of them taken, which was a revelation to me. 
These fishermen were on hand for any edible fish which might come along, sinking or trolling, as the case might be, for cod, blue-fish, barracuda, and flounders, or for mackerel, sea bass or salmon. Their fishing was entirely with cotton handlines, using small fresh fish for bait, which abounded in plentifulness.

I was strongly affected in contemplation of the field before me, and will give an account of my experiences in this remarkable arena, where the sportsman's king of fishes, the salmon, could be taken in full vigor in the open sea, lustrous and eager in the pursuit of its natural food, undiminished by the abstinence and confinement incidental to river pool life, at the commencement of the long fast which ordinarily terminates its existence.

To see these vigorous, combative monarchs of the Salmo family brought up along side of the boat, swerving in the pull, from side to side, by powerful strokes of tail, and never ceasing in their fighting gameness, even when struck by the cruel gaff, with its following of spurting ruddy life's blood, or until the fatal brutal head blow given in the boat.

Ignoble and inglorious this ending of the silverspangled warrior of the deep sea, whose speed through the crystal waters equals that of the dolphin, or any denizens of the sea-equal almost to that of the fleeting hare on land. To see this sparkling form in fresh fulness, in the last tremulous throes of death, seemed a sorrow. Still, perhaps, it was better to die thus in perfection of life and action than slowly to perish from exhaustion and mutilation in a stagnant pool, or, blind and bloodless, gasp in starvation amid the whirling eddies. 
I saw enough to fire my hope and expectations, and from the city I obtained two bamboo bass rods of good strength, with large multiplying reels having rubber thumb pads, with six hundred feet of twentythread linen lines and suitable hooks. The bamboo rods I soon smashed up, but they lasted with repairs and lashings until I secured by telegraphing to New York for several six-and-a-half-foot steel trolling rods with agate line runners, weighing ten ounces. These I found most appropriate, and capable with careful handling for all the salmon I caught, and with one I handled successfully a ninety-pound shark, which after some time I brought to gaff.

I engaged a good-sized fishing boat, applicable for sailing, and two men, fishermen and old whalers, and in the next three months I made forty fishing trips, almost invariably leaving my lodgings before the clear dawn, rising generally at four o'clock in the morning; and from my trips I secured over five thousand pounds of salmon from trolling-a record I can never expect to duplicate (nor have any particular desire to), as the season of $\mathrm{I}_{892}$ for profusion of salmon at Monterey Bay has never been equalled since, and in a few of the intervening years only a moderate number have been found there, with following good years.

I have followed the salmon trolling there moderately during the years since, and expect to do so again, but have only met with moderate success. The feature shown there is comparatively unique, in the finding of salmon which eagerly take fresh fish bait in the open sea, not known of in other waters than the Pacific, though very rarely salmon have 


\section{A Sportsman}

been caught in European waters with spawn bait. This may be accounted as a compensation by the Pacific salmon for the non-taking of the artificial fly, so universal with its Atlantic and European prototype. Nor is there on the Pacific Coast any such area of profusion of bait-taking salmon as that stretching over a distance of fifty miles from Santa Cruz and Monterey to Carmelo. At Puget Sound, and at the mouths of the Columbia and Fraser rivers, the salmon likewise take bait in the sea; but more incidentally on their passage to the rivers, without abiding for weeks as they do off Monterey, and before the ova has advanced toward the voiding condition as with those salmon seeking passage up the rivers.

In fact, the salmon coming off Monterey are more behind those seeking spawning beds. They have simply followed their food supplies from some sea depth. It is a very interesting sight to witness the coming in and arrival of the small fish and squid, accompanied by myriads of predatory birds, who now welcome the harvest days long waited for, which unite them from their before-scattered locations, in clouds composed of many thousands, animated by a common impulse for deglutition and destruction, exponents of the creatures of nature, to kill and devour. The small fish coming in the summer and the early autumnal months into and adjoining Monterey for spawning are largely anchovies and sardines. These fishes are about the size of herrings, though there are two sizes of the sardines smaller than the regular full size. These come in countless numbers, as well as the anchovies, swimming near the surface, and often cover 
acres in extent; and also the squid, a miniature octopus in appearance, soft and boneless, which come in prodigious quantities, and, keeping at the surface more than the small fish, are more easily captured by the sea-birds, although they seem the favorite food not only of the birds, but of the salmon and a dozen other kinds of fishes, as well as of seals and sea-lions, but the quantity is so immense that little impression is made upon them, or even upon the anchovies and sardines. These schools can be observed a long distance off in a clear sea, though not immediately at the surface, by the reflection of their color.

Nor should we fail to observe that all fish life existing in both salt and fresh waters owes its existence to an article of food which is invisible to the naked eye: to the endless variety and extensiveness of the animalcules and protozoa which the infantile fish, whether supplied with umbilical sac or not, depends upon for its first growth. This furnishes another exhibition of the automatic revolution of the water supplies. The squid is too delicate and tender for salmon bait, although the stomachs of the captured salmon show

Note by the Editor of The Sportsmen's Review: It may properly be mentioned here that Mr. Whitney received the credit of first exploiting and giving to the public the proper methods of taking the Pacific salmon in the sea, in a sportsman-like and artistic manner with a light trolling rod and fine line, as accorded to him by the prominent California newspapers, also in foreign sporting papers and journals. His descriptions, given out in 1892 , had wide circulation among foreign sportsmen, being translated and published in several languages. The New York Forest and Stream, referring to him, said: "Salmon fishermen the world over owe a debt of gratitude to him for his extremely interesting accounts of sea fishing for salmon on the Pacific Coast. Though that fishing has been known for years to a limited number of anglers, he has been the first one to exploit the sport in adequate description for the benefit of the guild, and may fairly lay claim to the discovery. Others may have known of it as the Norsemen knew of America, but he has been the Columbus to proclaim his discovery to the world, and to command for it the attention it deserves." 


\section{A Sportsman}

more squid than anything else. It is a repulsivelooking object, yet is accounted by many of the Portuguese and Italian fishermen as a great delicacy, and is served up fried in some of the San Francisco restaurants. By the Chinese it is considered very good, and until late years, when the fish commissioners have forbid it being taken with nets, was hauled in and dried by the hundreds of tons and shipped to China, where it was accounted a leading luxury.

The objections of the fish commissioners were not founded upon a fear of diminishing the supply, but more from the general protests of residents about the Chinese coast fishing grounds, as the odor from acres of sun-dried squid was particularly offensive.

The method of securing the squid followed by the Chinese was by netting at night. The squid was attracted by displaying lights from boats, about which the squid would cluster, whereupon other boats would circulate around with large purse nets, and secure immense hauls.

I have seen these squid stretched out on the surface of the sea for over half a mile in length, and overcast by such clouds of muirs, shags and various fisheating birds as to be uncountable, and I have often estimated as many as ten thousand birds of this character on and hovering about a single field of squid. Some of these birds will gorge so thoroughly as to be incapable of flight, and if pursued in a boat can be knocked over with an oar, and when pursued will often disgorge as followed until they are able to rise from the water.

On my first excursion out, from an early hour until Io o'clock I was very fortunate in taking in eleven 
fine salmon, which weighed nearly two hundred pounds, the smallest being a grilse of eight pounds and the largest twenty-four pounds. It is needless to say that I followed the fishing with eagerness, making an excursion out about every other day, generally finishing up before noon, but two or three times I was out all day when the salmon were very plentiful, making notable catches. It was seldomnot more than two or three times out of forty-odd trips-that I failed to fetch in salmon, so one can see that the fishing condition was most remarkable, and no season since 1892 has shown its equal. My largest catch when out a whole day, which occasion I more fully refer to hereafter, was twenty-nine salmon, weighing 5 I 2 pounds, averaging a little over seventeen pounds, my smallest salmon that day weighing eight pounds and my largest thirty-eight pounds. I carefully weighed all the salmon I caught, the total number being 320 , and the total weight being $523 \mathrm{I}$ pounds. The largest salmon was fiftyfour pounds, which I had no particular difficulty in fetching to gaff, excepting in the time given. The short steel ten-ounce rod is a very efficient one, and will bear a much stronger strain than a heavier bamboo rod, especially when a heavy fish sulks below the boat-and it is the disposition of sharks to do this more than salmon.

The small-sized sharks in Monterey are very plentiful, the larger portion of them being under twenty pounds in weight, which can easily be brought in, although there are many which weigh from a hundred pounds up, and when one of these is struck it is better to let him go, after securing all the line possible. 
Two of the largest sharks known in any waters are occasionally seen off the bay-the whale shark and the basking, weighing tons. The former is seen rarely, but the latter often. Neither of these is known as a man-eater.

It is necessary from the Monterey pier to row off two or three miles to reach the salmon, and sometimes farther, and the sea is not always smooth, oftentimes too rough for those inclined to sea-sickness, and the mornings are generally foggy, but clear up before noon, when the prevailing west wind comes up, which enables one to sail back to the pier.

It is necessary ordinarily to sink the baited hook from thirty to forty feet below the surface, and sometimes lower. This requires a sinker of four or five ounces in weight to keep down the hook, when rowing the boat at a speed of about a mile and a half an hour. I found the sinker an inconvenience in the free playing of the fish, and devised a method to free it by fastening it to a short piece of extra line, which I attached to my main one, by a peculiar bow-knot, thirty or forty feet from the hook, so that I could detach it by a hard pull, as I reeled in after the strike; as the salmon when first hooked at a depth almost invariably remains below for a while, without commencing its wild runs away, which occur when thoroughly alarmed at being brought up near the surface. The first action is generally of violent head-shaking to detach the irritating hook, and by this head-shaking, communicated along the line and rod to the fisherman, he is aware of a salmon being on, rather than another fish, and as he immediately and steadily reels up, the bow line-attachment of the sinker is brought alongside of 
the boat, and quickly removed by one of the boatmen. But not always does this method succeed, as the salmon may be off before it can be accomplished and the sinker in such case may remain, clogging the free runs, until the last one.

I devised a much better method later on for throwing off the sinker. My steel hooks of three quarters of an inch spread at the bow, and long shanked, I had soldered on to a stout brass wire of four inches in length, and this connected by two more pieces of similar wire and length, by stout brass swivels. My four-ounce leaden sinkers, round and tapering at each end, and having a hole through lengthwise, I strung over on a not overstrong cotton string, and caught up the lower end of one of the brass links below, connecting it with the one above by the cotton string carrying the sinker. The string was strong enough to carry easily the pull of the trolling bait, but would break and drop off the sinker by the strike of the salmon and leave my line free. The loss of the sinker would, of course, occur, but was of slight importance and value.

As the hooked salmon approaches the light at the surface, and has been unable to throw off the hook, his alarm is much increased, and he starts out with great rapidity in some direction opposite from the boat, and with an impetuosity impossible to speedily check. It may be two or three hundred feet, or more, before the hard-pressed reel pad on the line and the strain of the rod almost surely incline the head of the fish to one side or the other, which being once accomplished practically settles the successful take; for the salmon, once being turned from a straight 


\section{A Sportsman}

course, must thereafter yield to the boat in a circling route, from which he can hardly escape, carrying in addition to the rod and reel strain that of dragging the line across the waters.

Should a large salmon-say of twenty-five pounds weight or more-go directly away from the boat without being diverted, it would most likely run out all the line and part it, as occurred in two instances during my experience. But the severe strain which can be exerted from the reel and rod is almost sure to divert the fish from its apparent fixed purpose of getting away as far as possible from the boat on the route it first determines upon. A sufficient pressure can be put upon the thumb pad of the reel to part the line, or tear out the hook if not firmly placed. A danger also exists from the overrunning of the line if the drag is not judiciously applied; also from the line's sinking in the balance of line on the reel when too much pressure is applied, particularly when the line has not been firmly and evenly reeled in before, from which cause an entanglement takes place and the salmon is almost surely lost.

A large shark occasionally takes the bait, too large for handling, and taking to the bottom cannot be raised by any strain from the rod, and has to be cut away. A variety of other fishes will also often take the bait, although if the salmon are present in force they will take the bait almost exclusively. Among those mostly taken while salmon trolling are the rock cods, from four to twelve pounds in weight, which, unlike those of the deeper offshore waters, of the usual color, are a handsome fish varying in many degrees of red and brown, and are excellent eating. Next most plenti- 
ful are the so-called blue-fish, not to be classed with those of the same name on the Atlantic Coast, being shaped like the cod, excepting flatter, and good eating. The small sharks are a great bother, plentiful and worthless. Sometimes a school of large mackerel is struck, from which a number may be taken, weighing from two to four pounds. Also a school of sea bass, not the striped, introduced in late years from the Atlantic waters, but the indigenous silvery bass, which run from fifteen to sixty pounds, and afford good sport from their gamy qualities, fighting hard for five or ten minutes, but passive when yielding.

These are highly esteemed for market fish. They are not generally struck with the salmon, but by themselves apart, and more often about the beds of kelp, and when found may be well followed up for sport, and a good score may be made from them, as a school is often extensive.

Yellowtails come in later in the season, running from ten to thirty pounds, which are very gamy, but not applicable for food. The leaping tuna is also an occasional visitor at Monterey Bay, and it is a great sight to see a large school of these moving rapidly forward on the surface of the perhaps rough water, breaking and splashing the waves with their powerful tails, leaving a wake of foam and commotion. They are, however, very rarely taken in the bay, as they frequent the waters south more plentifully, particularly at the Catalina Islands.

I had the good fortune on one occasion, when a school was about in Monterey Bay, to take one of sixty pounds, which gave me great play, and which at several moments I expected to lose when brought 
to the extremity of the line, but it fortunately turned, enabling me each time to take in slack, and I finally brought it to gaff after half an hour's fight. On the same day my hook was taken, evidently by a still larger one, that made a straight run off, carrying away all my line with startling rapidity, upon whom my attempts at checking up made no impression.

Off the Catalina Island-which lies a few miles from the California coast opposite Los Angeles- the tuna is oftentimes found in profusion during the summer months, and is undoubtedly the largest game fish in the sea, and is often found much larger than the ability of a rod fisherman can possibly overcome, running up to several hundreds of pounds, and even a thousand pounds has been given as a maximum. When struck it goes off with great speed, with occasional leapings from the water, and slashes about in a manner indicative of great power. The favorite bait used at the island is the flying-fish, employed with a special rod and reel, and a thousand feet of line. A tuna of two hundred pounds may be accounted as the limit, and requires several hours of hard work to fetch in. It is in reality a huge horse mackerel, and worthless for food, and is thrown away for the sharks and other fishes to consume.

The jewfish, or large black bass, is plentifully caught also at the island, and, being of less fighting. qualities than the tuna, is brought in weighing several hundred pounds, after hours of dull, heavy work

The yellowtails are more plentiful about the Catalina Island than elsewhere, and although worthless for food are perhaps the very gamest fish in the sea for their size, and run up occasionally to fifty pounds. 
At Monterey Bay they are frequently found, and he who gets one on his trolling line will have the liveliest work of his experience; and, as with the tuna, it is full of irregular actions, and unexpected turns, and may suddenly, when apparently bound for some distant clime, come with a rush for the boat faster than one can reel up, and double on the line and mix itself up in a most unusual manner.

Monterey Bay is certainly a most attractive area for the fisherman's sport, and without the salmon his chances are most favorable in trolling to strike some fish which will give him delight. It may be a shark or a sea bass, or a barracuda, blue-fish, or cod or flounder. Perhaps he will strike a school of mackerel, from which he can take in a score or more.

It is estimated that in the bay there are over a hundred varieties of fishes, and it is not uncommon to see a whale in the offing, or perhaps within a few hundred feet of a boat, as I have seen them as near when trolling. A young one of twenty-five feet in length made himself unusually familiar for several days in the cove of the bay a mile out from the pier, a place popular with the ground fishermen, whom he alarmed with his playful ways, and one day bumped roughly against one of the boats, and was shot at a number of times, which he resented by taking his departure.

The grampus, belonging to the whale family, are quite common in the bay, and have frequently annoyed me when salmon trolling by their familiarity, coming up and diving near my boat, particularly one of them, which made his rendezvous off the shore in a locality I usually passed over on my way to the 
outer salmon grounds, and where I had been taking a salmon occasionally as I passed by. His presence in that locality was sufficient to retard the free action of the striking salmon, as they shy off from the immediate proximity of large fish, which are presumed to be destroyers; and this grampus, it seemed to me, indicated a conspicuous intention of waylaying my boat each time I passed, and would throw himself up out of the water sometimes alarmingly near, almost threatening my boat's safety, so near that he could almost be touched with an oar.

It was not very pleasant for an immense cetacean of this character, of from twelve to fifteen feet in length and weighing over a ton, to come up within ten feet of the boat in his porpoise-like frolic, however friendly might be his disposition, and I made an inward vow to look after him shortly, and accordingly went out in a following afternoon equipped for him with a large sailboat and my two men, a whale harpoon and rope, and a musket carrying an ounce ball. We found him in his usual locality, and soon had him come up within fifteen feet of the boat, and I cast my harpoon at him with all the force I could muster; but my want of experience in this line was limited and I failed to fasten him, and he gave no further opportunity for a good cast, keeping too far away, and after an hour's effort. I concluded to give him a shot from the musket. This I did as he rose some fifty feet off, aiming at his head. I heard the ball strike him, and he disappeared. Little expectations I had of seeing him more, though we tacked about for half an hour, but saw no further rises from him, and turned homeward. Looking aft as we 
proceeded on, I saw what I thought to be a red blanket floating on the surface of the sea not far astern, and drew the attention of my men to it; a veritable red blanket it seemed, but my men said immediately it was the blood from the grampus, and we put back towards it, and shortly saw the grampus come out and down, not far off. As I observed him when he came up I distinctly saw the blood running down the side of his head, and again and again he came up and down, still bleeding. This indicated a severe wound, and the grampus by its slow movements convinced us that its end was near. With harpoon ready we followed close, and I soon had a close approach as he came up, and put the harpoon in successfully, when, allowing a good slack, we warped the rope around a post in the bow of the boat, and went off at good speed, with a crest rolling wave at our bow. We found he had much strength remaining, and kept up his brisk gait for ten or twelve minutes, when his speed diminished, and soon after gave out entirely, and his huge body floated on the surface. We waited for his death flurry, but it did not come, and we hauled our boat up to him and fixed a noose line over his broad tail, and set sail with a fair strong breeze to the Monterey pier.

Quite a number of bathers from the Del Monte were in at the beach watching our approach when we landed from our boat. Our grampus was grounded some thirty feet from the shore, and all joined us in the haul ashore, making an advance with our grampus with each successive lifting wave as it rolled in. But the united force was not sufficient, with more than a score of pullers, to get the body clear from the water, 


\section{A Sportsman}

and the finale occurred when the last grand pull took place, which broke the rope, and sent all tumbling down on the sand. The tail end of our victim was well out, however, and the retreating tide soon left him clear. I gave him to my men, who tried out two barrels of oil from him. We estimated his weight as a little rising from a ton. His black, glossy hide, for he had a veritable hide, was tough and thick, and almost impervious to the penetration of a knife blade. He had a few blunt teeth on his lower jaw, two inches in diameter, but no others. My ball had penetrated by chance a large blood vein, cutting through to the lungs, which was fatal.

The grampus is not a fish, but a warm-blooded animal of the sea, kindred in family with the whale, killer, walrus, porpoise, dolphin, etc. Its food principally consists of small fishes, and the occasional large class, as salmon, cod, flounders, etc., when good fortune attends his comparatively slow movements.

Another animal of the sea of the grampus family which I had experience in meeting, of which little is known by the general public, is known as the killer (Orca Gladiator of the genus Orcinus). This is the freebooter of the sea, the pirate, the terrible; ravenous and ferocious, and of desperate courage. As the wolf, it fights in packs, and nothing in the sea can withstand it, when united with others in contest. The mighty whale, the largest animal of nature on earth, succumbs to the united efforts, and the wonder is that even they can exist.

It is no idle tale I shall relate of them, nor do I mean to adduce any instances as facts which cannot be substantiated by sufficient evidence. If you will 
consult the Encyclopedia Britannica you will observe the instance of one captured, measuring thirtyseven feet in length, which contained thirteen porpoises and fourteen seals, which seem almost incredible.

Their habitation is principally in the northern and Arctic seas, though found about as far south as Monterey. Their usual weight is from three to four tons, and their length twenty-five to thirty feet. Their food is principally of their own genus-warm-blooded animals of the sea, porpoises, walruses, seals, sea-lions, etc.,-and like the wolves of the land they devour their own wounded kind. They have enormously large mouths, capable of taking in a whole porpoise or seal, and have immensely strong jaws with about forty tusk like teeth, of an inch and a half diameter, and from two to three inches in length, with a double row on the lower jaw.

They will attack a whale without hesitancy, and tear from the lips and sides slabs of a hundred pounds, and follow to the greatest depth the whale will go. The whale, timid by nature, will flee before them, and when hard pressed will loll out its tongue as a dog will when fatigued. This will be seized by the killer and torn away, and my boatmen-both old whalersrelated to me two instances, occurring off Monterey Bay, where whales were taken, for what blubber remained on their bitten-up carcasses, dying, tongueless, and this was substantiated to me by Michael Noon, a responsible man in charge of the Monterey pier.

The business of whaling has been carried on for many years from Monterey, by men engaged in it from land stations, who when observing by glasses the blowing of whales off the coast, go out in their 


\section{A Sportsman}

whaleboats, equipped with the usual outfit, and after harpooning and securing a whale, cut off the blubber, and securing, tow it in rafts to the shore for trying out the oil.

Several instances have occurred when, securing the blubber and towing it by their boats to land, they have been attacked by the killers and lost their cargoes. One of my men related to me, having been on hand in such an instance, the particulars in the case; that, suddenly attacked by a pack of killers when towing in two rafts of blubber they had obtained by cutting up a large whale, they were powerless to prevent the total loss of their rafts, although they lanced a number of the killers, which had no effect upon the balance of the pack. I saw one of these killers towed to Monterey beach, which had been found by the fishermen in a dying condition. in the bay, resulting from being choked by an extralarge seal, and had three other whole seals in its stomach.

Singular that no instance is known of a man's being taken in by a killer, while swimming in the water, or of boats being disturbed by them, when it would be a simple feat to knock them over, or crush them. The largest sharks will flee before them, and will be fortunate if not torn to pieces and devoured by them, which is a common occurrence. Seals and sea-lions are a favorite food for them, and the largest of the latter, of the weight of a ton, with its hide tougher than that of a bull, will be torn to pieces and devoured by them in short order.

The sea-lions are very plentiful on the coast, off the seventeen-mile drive between the bays of Mon- 
terey and Carmelo, and can be observed at times upon the island rocks off the shore by scores, resting and sunning themselves after their food-seekingswims, and their roaring can be heard a long ways off. Alert and swift as they are in the sea, they are slow and clumsy on the rocks, and in getting out of the water upon them. On the approach of the killers they can be seen coming in from all quarters, and hurriedly seeking refuge on the rocks, and seem to receive an intimation of danger in their scattered localities, by that yet unknown and undefined sense which communicates alarm and occurrences so often between the denizens of the sea, though widely separated. The salmon also cease feeding and disappear upon the approach of the killers, striking out in a body for deep water, and cannot be caught for a day or two in the previous localities.

As well known to whalers, when one in a large school of whales separated over an area of a dozen square miles is harpooned, it is immediately communicated to all others, though a number of miles intervene between them. This has been repeatedly observed from a whaling ship, and by the second boat out for harpooning, when the first boat has fastened to a whale.

The first appearance of the killers occurred with me one day at Carmelo Bay, nearly twenty miles south of Monterey, where my boat was the sole one in that pretty little bay of two miles wide. The first intimation I had of the approach of the killers was when we saw several sea-lions hurriedly clambering up some island rocks near the shore, and the salmon, before plentiful, had ceased striking. 
"Killers," said one of my men, "and there they are," he continued, "a large pack coming around into the bay from a point south."

I looked and saw them, not half a mile off, a singular sight, like a broken body of infantry with bayonets up, and nothing more visible, a very peculiar sight, for the killers have a slim black dorsal fin, some five or six feet in height, which they carry afloat above the water as they swim along on the surface, as they proceed when not engaged in pursuit or feeding. We were a mile away from our landing, and I will confess I felt a sudden emotion of apprehensiveness, as I saw this murderous gang of sea bandits coming directly upon us. But my men said, "No fear, they will not harm us," although I found they had some little apprehensiveness themselves.

Soon they were all around us, but scattering, with occasionally some so near that we could plainly see their black bodies, with the white splashes on their heads; sportively, some were slashing carelessly about with their cross-set tails, plainly evincing their great power, and I thought how easily one of them could smash up our boat in a twinkling, if desired. I estimated their number at one hundred and fifty, which my men conceded, for they could not be readily counted, as some of them would go under now and then for a time, soon reappearing. It was a most astonishing sight, more so than anything I ever witnessed, and I have seen half a hundred whales about me. They were so many pirates of the sea with their black flags hoisted. I thought some of them looked at us very suspiciously with their oval eyes, white-spotted below, 
but they were evidently at the time good-natured. I was relieved when they passed on, and they apparently gave us small regard.

Think of the immense amount of food daily required by a band of one hundred and fifty of these pirates, and how bountiful it must be, but there are hundreds of thousands of porpoises, seals and lions waiting for them. Fifty tons of food would no more than give a good meal for one hundred and fifty killers.

I had before reeled up my line, as successful trolling for salmon was of the past, and there were no more salmon caught there for several days. In fact, the killers ended up the good fishing for the season.

Among the owners of market fishing boats, and fishermen at Monterey-where there are quite a large number, as the station is one of first importance in supplying the state demands-are a number of interesting personalities: old whalers, sailors and sea rangers. Most of them are Italians and Portuguese, with a motley variety of Americans, Swedes, Norwegians and Mexicans, down to the industrious Chinese. The latter are much by themselves, and confined mostly to near-shore ground fishing, and netting of squids, shrimps and small fish. They have almost exclusively the gathering of the large abalones found on the coast between the shores of Monterey and Carmelo, which are gathered at low. tide. The abalone shells are in demand for the beautiful iridescent colors shown on the inner surface, and the meats are dried in the sun for export to China, with shrimps, squid and small fishes. 


\section{A Sportsman}

It has been very interesting for me to hear the yarns from some of the old whalers and sailors, too numerous to recite, and in some instances perhaps beyond reasonable belief. A recitation of their yarns would fill a tolerably good-sized book. It was a favorite frequenting place of mine at the pier during the several months I was a resident of Monterey, early in the afternoon, to see the catches of fish which came in by the returning fishermen, for the varieties of fishes were numerous, with an occasional showing of something remarkable, out of the regular line.

One of their accounts relating to the "killers," which I have referred to, interested me very much, of which I have remembrance of seeing some account in some newspaper, and, although of extravagant quality, I will put it together as best I can; for the account, seemingly so improbable as it would appear to many, does not seem so to me, and if the incidents relating to the aid given to the whalers by the killers did not take place, I believe that they could be made to occur.

The scene of action was at Twofold Bay, a deepwater harbor off the southern coast of New South Wales, one noted for its varieties of fishes, as Monterey Bay is on the California Coast.

The killers, though not numerous there, frequented the bay to some extent, and my informant had witnessed their actions in different waters and when in combat with whales, and in one instance when they were accompanied by a thresher shark of enormous proportions acting in union, which dealt fearful blows upon a whale attacked, with its striking tail, its adaptation in that respect being remarkable, 
while the killers tore the unfortunate victims to death, at which they joined in devouring.

At the Bay, a family of Davidsons-father and sons - had established a whaling station similar to the one at Monterey Bay, where they had carried on for many years the business of whaling in conjunction with a moderate number of killers, a dozen in number, with whom the family had intimate and friendly business relations, which had existed over a dozen years. These killers periodically departed from Twofold Bay, but would return regularly to their accustomed haunts, and were so familiar with the Davidsons as to be named separately and individually: one Tom Tug, from his stripping success, another Fatty, another Flukey, etc., each being well known and separately designated.

The killers accompanying the Davidsons with boats, would seize and hold a whale while the father and sons would lance it to death, whereupon the killers would drag the whale below and feast upon it to their fill. In a day or a day and a half, the whale would from a natural action rise to the surface, the place being marked by a buoy; whereupon the body would be towed to the shore for trying out.

The method of holding an ordinary-sized whale was most systematic, the killers distributing themselves about the body, and fastening on with bulldog-like grips, with an occasional letting go by one or two of the killers, who would swim off a matter of fifty or a hundred feet, and returning with all their speed would strike the whale the most terrific blows with their heads, and then fasten on again, 


\section{A Sportsman}

anon tearing off large slabs of blubber from the belly and about the head. At times the whale would get below before it could be lanced, but would be followed to any depth it could go, returning more or less exhausted to the surface, throwing itself out clear with the ferocious wolves of the sea still fastened on.

The Davidsons stationed one of their number during the whaling season by or at an old lighthouse on a headland, where an open view of the sea was shown, and here the sea was scanned by the aid of a powerful glass, and from where the spouting of a whale could be observed at a distance of two or three miles; but when a whale in its pleasant mood "breached" by throwing itself bodily out of the water, as it is wont to do, creating a great commotion and splashing of waves and spray, it could be seen five or six miles off. The killers of course could not see this, lazily sporting about in the small bay, spouting now and then, and showing their black glistening backs as they rose to roll or dive, remaining in waiting during the whaling season, not far from the two whaling boats kept in readiness near the trying-out station, their dependence being largely placed upon the Davidson family.

Whales being sighted out in the offing, and the fluttering flag signals two or three miles south from the boats, thrown out at the light house station, aroused excited action at the boat station, and the men at the trying work rushed to the oars.

"There they blow, at the north-west, humpbacks steering north."

Off went the boats, fully equipped, at their best speed 
but they did not escape the notice of the killers, who ranged themselves alongside and ahead of the leading boat, keeping well outside the oars, leaping, rolling and breaching in wild joy with the prospects of a bloody fray. As they approached the whales a slower oar was pulled, and in a moment the killers disappeared. They had heard or seen the spouting and splashing ahead, and before the boats could arrive were among the whales.

Humpbacks, sure enough, and now a mighty scene of uplifting of huge bodies and lashing of the waters occurs, an area of white swirling foam, amid which the frantic whales sound for escape, but not before a dozen ferocious killers have selected their victim, which they are to do more than half the work in capturing. Skilfully avoiding the flukes, they fasten on with their bulldog grips, tearing away as they can huge strips of skin and blubber, especially fastening on about the head. Their victim, distracted and torn, vainly attempts to sound with his comrades, for now they are gone, and if he can possibly follow, he cannot rid himself of the devilish fiends who beset him with undiminished savagery. Perhaps half a hundred fathoms he may sound, but never a moment can he be free from his desperate clinging destroyers. Bleeding and frantic, and more winded than his wont when below, he must return to the surface again, where the boats manned with human foes are calmly awaiting his appearance.

There is no escape for him in the depths of the sea, nor where the sunlight in fulness gleams. He may rise near the boats or some distance away, but he cannot get below again, for his enemies are too power- 
ful, leaping at times entirely over his body, and attack him with redoubled fierceness, tearing away from above and below, from the great corrugations of his ribbed belly, and his huge lips, and perhaps have already torn away his elephantine tongue, which for the killers is a delicate and sought-for morsel. One or two of the killers may illustrate the great pounding act, one blow of which has been known to render a whale temporarily senseless, and the hapless victim, the largest animal of the earth, now near its last extremity, moves around in circles, sometimes turning over on its back, or swimming on its side.

Now, then, for the last act in this sad drama. The leading boat cautiously pulls for the favorable putting of the iron. The long lance is sped by powerful hand in a vital spot and penetrates the tough skin as a fork would that of an apple. Withdrawn, the warm blood gushes out following, and perhaps two or three more swift thrusts are made with equal success, and then with the cry "Stern all!" the boat backs away from the death flurry, which even the killers drop away from. All is over, and the mighty monarch of the ocean, with its mountain of flesh, is placid in death. Scarcely, for before the last tremulousness of the flurry is over, by a simultaneous effort of all the killers, the body is seized and dragged below; as the sanguinary animals of the forest drag their victims to convenient places for devouring, so with these wolves of the sea, who invariably, as experienced by the Davidson family, drag the whale's carcass to the bottom, or at least to a considerable depth, where they indulge in a great feast, gorging themselves to fulness. 
The boats, dropping out a buoy with sufficient line, with which they are prepared, return to the shore, until the second day after, when if the whale carcass is not yet up they wait for it as it is sure to soon after come up, when it is towed to the trying works. The Killers, whether actuated by a sense of duty or not to render proper obsequies to the departed, accompany the body to the surface and to the trying works; but it may be a question if their inclination to blubber has not a bearing on the subject, and if they are not influenced more by a selfish desire.

At least the killers accompany the body to the trying works, and are a safeguard against sharks, giving themselves interim a replenishment of stomach, which is a slight loss, compared with the advantages of their services.

The Davidsons claim that with the late low prices of oil they could not carry on the whaling business without the aid of the killers, and have been reticent about giving the information, which is imparted here by one who claimed to have been a personal witness on several occasions, acting as an employé, and who states many other particulars; that there had been other occasions than those experienced by the Davidsons, where the killers had rendered material aid to whalers in the north seas, that no instances had ever been known when the killers had ever disturbed boats, or injured men in the water, though they had been known repeatedly to approach men who had been knocked overboard and to sniff at, and go away from them, without any manifestations of devouring interest; that they were, despite 


\section{A Sportsman}

their ferocity, the most sagacious, cunning and expert creatures which lived in the sea, possessing unparalleled daring and persistence, and would hover around the sea-lion rocks for days, and had been seen repeatedly to come up suddenly from deep water close along-side jutting-out rocks where sea-lions were basking, and snatch them away, although they were five or six feet above the water-this has been confirmed by a number who claimed to have witnessed it; that whalers have witnessed them not only with the thresher or fox shark, but accompanied by large sword-fish in attacks upon whales.

Think of what a grand sport and top holding in sports this would be for an ambitious sportsman wishing to exceed all others and achieve the record over all, with the ocean for his field and the whale for his game, with a pack of killers at his heels, and it may be recommended to those who are ennuied with the tame pastime of hunting wild boars, stags, and mountain lions with dogs, to take a holding on some northern coast station, and give himself over to the conquest of mighty whales, the largest animals of creation, attended by gladiatorial bulldogs of the sea.

The captain of a whaling ship which returned from a winter's whaling in the Behring Sea, a few years ago, gave an account of the capture of a killer by the natives of that locality, which he witnessed. It was at the season when the ice pack was breaking up, when the walruses, sea-lions and seals were being disturbed from their winter quarters on the ice and compelled to seek other quarters, a period when, according to the natives, the killers, long absent, 
would be sure to come for the advantages to be gained in the breaking up of the pack, as they usually appeared at that time in a most ravenous state.

The natives had been patrolling the ice pack for some days for walrus, and a visiting party accompanied the ship's crew, who were anxious to kill a walrus. The ice, open in some places, was generally weak when frozen over, and the creeping on to the walrus was followed with caution. Some walruses were observed in a group near an open water space, and as the party was approaching with great care there suddenly arose a huge black object through the ice from the water below, throwing up the splinterings of ice high in the air, and seized a walrus, dragging it down below. It was the work of a moment. It was a killer, which, observing the walrus from a starting place below, had shattered the decaying ice with its ponderous head, impelled with a velocity which had been known to strike a whale momentarily senseless. The witness was informed by the natives that an occurrence similar to this had been frequently witnessed. Shortly after this the ice broke up in the bay, and was blown out by an off-shore wind, when the Killers became plentiful, and their spoutings were often heard and seen.

One day the natives started out with three of their largest boats, each manned by half a dozen rowers, with harpoons and steerers. Once in the bay they took different directions. A mile out the killers were observed, first a school of them, their high dorsal fins standing out distinctly against the horizon, and at times their glistening backs in the sun. Their movements were slow and deliberate, as they swam 
slowly in single file, so slowly that it was easy to approach them. When near, the leading crew approached with great caution, avoiding the slightest splash or noise, but urging their boat at the greatest possible speed.

The largest leading killer was selected, which sunk itself moderately in the water so that the boat passed over it, and at this critical moment the harpooner threw his weapon with all his power. As the harpoon struck, the boat was backed with all possible speed, but none too soon, as the killer immediately leaped six or seven feet clear from the water, and then dropped back with a resounding crash, sending heavy waves after the boat. The moment the killer fell to the water it sounded, tearing the rope from the coil with such velocity that it fairly smoked from the friction at the run out; several hundred yards were taken in this way, when the killer, evidently grounding, came up with terrific rapidity near the boat, which the dragging of the rope was of trifling importance in retarding. As the killer reached the surface, it came entirely out of the water again, falling back with a crash from its own weight. As it fell, it lashed the surface water to foam with its powerful tail, doubling itself up, and striking out frantically in its efforts to cast away the impaling harpoon. As it straightened, its flashing tail would strike on the surface with a noise like the report of a musket. Finding it could not disengage itself from the harpoon, it commenced to swim around in a circle with its back exposed, as if looking for its enemy. Meantime the natives, not alarmed, hauled in the slack with all their might. 
When the killer felt the pull it plunged down and swam rapidly out to sea, the boatmen in the meantime giving some turns of the rope around the bow post. For several miles the boat was dragged with a velocity that imperilled its safety, taking in much water which had to be constantly bailed out. After several miles had been gone over the killer fortunately turned back to the bay, with apparently less speed than first given, which gradually diminished after an hour's towing, and finally so that the boatmen hauled back the rope to within 200 feet of the killer.

The other two boats, which had followed as well as they could, were now enabled to approach and send in their harpoons to the back of the killer, now exposed. Under this additional affliction the killer sounded, but not to a great depth, for it immediately appeared, attacking one of the boats from below with its head, which struck amidship, sending it shattered into the air, and throwing out its occupants, who managed to reach one of the other boats, where they were hauled into safety.

The killer, without paying any attention to the swimming men, completed the destruction of the boat with its powerful tail, exhibiting while so doing the snapping of its ferocious teeth. The killer then, apparently satisfied with the destruction of one of the boats, began swimming around in a circle upon the surface of the water, and as he became quieter he was simultaneously deeply lanced from each of the two remaining boats, which immediately backed off to avoid the death flurry. But too late, for the killer still had dangerous life left, and, instead of yielding up its struggle, sunk to moderate depth 
and came up at the bow of one of the remaining boats, the first intimation of which the inmates had was of its being crushed by the jaws of the killer. No attack was made on the boatmen now swimming to the last remaining boat. The end had been reached and on the surface came the furious flurry of the dying gladiator. Motionless then he rested amid the waters agitated in his last agony, with his glistening back flecked with foam.

A dear-bought victory, as it proved for the natives, who towed their prize ashore, hauling it in at high water, and when exposed a number of days, it constituted a long feast for them; for exposure and partial decay had no objective effect on the Alaskan appetite.

$\mathrm{B}^{\mathrm{u}}$

UT returning to the salmon. The average time I found necessary to fetch a salmon to gaff, I should estimate from eight to fifteen minutes, but occasionally longer; but once getting my salmon turned in a course around the boat, his fate seemed decided, and around it would go several times, often leaping out of the water, exhibiting its proportions. Once brought to the surface the salmon keeps near it in its runs, without attempting to go below much, until brought near the boat.

Certainly no sight is more beautiful or attractive to a fisherman than to see in the clear water this magnificent fish with its brilliant colors swiftly gliding along by the strokes of its powerful tail. When approaching the surface in its last exertions, it will appear of various colors, black one moment, then bluish black, with iridescent hues, and gleaming white as its belly upturns. 
But its energies are not entirely gone, as shown at the stroke of the gaff, when it exerts new life, and well held must be the gaff, with strap over wrist, or away may the fish go, if not quickly swung into the boat by the gaff, and will often flop out of the boat if the head blow is not speedily given. No sight can more gladden the heart of a fisherman than that of a dozen salmon in his boat as he returns from a morning's troll.

I should say that the market fishermen lose pretty nearly half the salmon they hook-at least when they strike a good school-for they act quickly to reap the harvest, and pull in with all their strength the hooked salmon on their stout cotton hand lines with large hook and sinker. They row and sometimes sail more rapidly than one would with a light trolling rod, and in their eagerness often attempt with the hook alone to lift their fish into their boats, often losing in this manner. They tear out the hook often in their rough hauling in. They sometimes fish with two hooks, having quite a stiff steel wire fastened to the end of their lines, with a spread of three feet, and on each end a baited hook on a foot line, and often succeed in hauling in doubles of salmon as well as of other fish.

But in trolling with a light steel rod, with the salmon freed from the sinker, it is almost invariably brought to gaff, and not one in a dozen of those hooked is lost, even those by a skin hold. I have repeatedly taken them in hooked in this way, and it is not difficult to know very quickly how the fish is hooked, and in the latter case handle more carefully, as trout fishermen do, when they have hooked a trout in the same way. But to hook a salmon foul, say on the back, entails a long winded fight, as has occurred in one or two of my catches. 
The taking of salmon in the open sea, fresh in their feeding habit upon their accustomed food, was such a novel experience to me that I took pains to study their methods of feeding, of approach, and attack, and the character of the food upon which they subsist, which gives them such astonishingly rapid growth. These particulars are important in accounting for the splendid condition they are almost invariably found in, when fresh from the sea. The parr or smolt, taking the sea in a year or two from the fresh water stream where it is hatched out, is nourished first from the umbilical sac, and following on the protozoa and ephemera, and is of light weight, less than a quarter of a pound, but in the sea gains a number of pounds the first year, when it is designated as a grilse. In two or three years more it is a well grown salmon.

At exactly what age they take to the fresh water from the sea for spawning cannot be positively stated, but it may be assumed that they do so after three years of sea life. Perhaps some may go to the fresh water after two years' sojourn in the sea, and some may wait four years. We know that the spawn exists in the young female identical with its growth, as well as developed faculties in the male grilse. The ova, however, remains, one might say, dormant, incidental with growth of the female, but after two, three, or four years' life in the sea, as the case may be, visibly develops, but does not reach the voiding condition until stimulated by the advent of the fish into fresh water. Fresh water is a necessitated element to anadromous fishes, and when the ova of such have reached a comparatively matured condition, the impulse of nature directs them to the spawning grounds. 
The sea fishing exhibits many characteristics of the salmon which cannot be observed elsewhere, and are entirely new features in the life and habits of this king of the streams, where but one side of its dual life has illustrated so many volumes. No accounts of accuracy have been given of its important life in the sea, until gained by viewing that real life as shown upon the California coast, where the salmon is observed in its normal condition engaged in the pursuit of its food of nourishment.

In the sea its life is one of progress, and in the fresh water, excepting at its commencement, one of retrogression and extinction. With its birth and first delicate life in the stream we are familiar, and with its swift advancement in the sea, and with its more rapid decline upon its return to that element which was so invigorating in early days. If there could be another chapter it would be that of its survival from the mountain stream after the spawning season in its return to the briny waves, such return, by a singular fatality, deadly in effect, but of this we have no history.

In the fresh-water pools, where the salmon rises to the angler's fly, it is made in a comparatively moderate way, and if missed, the salmon returns to its before-occupied place, where it must have a rest before engaging a following strike, and if followed up too quickly and eagerly, may entirely give up further attention; but if allowed to compose itself for a few minutes, may again rise and essay the gaudy deceit. Not so with the salmon in the sea, who is bold and aggressive, free in the boundless water, eager and fearless. Even if pricked by the 
hook's failing to fasten, he will again engage, and having secured but a portion of the vanishing bait will seize the remainder-if but a mere shred-and in his voraciousness become impaled; and I have several times taken a salmon which, taking in his first strike a portion of the bait, and hooked with a slight hold, has again struck the remnant of bait and, well hooked, been brought to gaff, which exhibited the wound from the first strike.

On one occasion I caught a large salmon of some twenty-five pounds, which struck fiercely and fought hard, but was in a very bad condition from two wounds gained in an encounter with one of the market fishermen, but otherwise in good condition of flesh. The wounds told the story. It had one side of its jaw and mouth cut badly by a torn-out hook, and a severe cut between its ventral and anal fins of three inches in length and equal in width-where a gaff had torn out. The gaff had penetrated nearly through the salmon. It was evident that he had been well hooked and gaffed, but brought in speedily hy the fisherman with his heavy line and hook while still full of life. In the clumsy and hasty work of the fisherman, one of the holes had torn out and afterwards the other, and the salmon went free, to finally fall a victim to my hook and gaff. It seemed hardly likely that this salmon could have survived the belly wound, yet he had not indicated any failing courage in striking my bait, or in his play.

I am reminded of a shark I once hooked in the Gulf of Mexico with a junk of salt pork and a chain hook-from the ship Western Star, long years agowhen I was a passenger on the ship on a passage 
from New Orleans to Boston. We were becalmed, and a large shark made himself at home swimming slowly about the ship, which excited a strong desire in my mind for his capture, and I got out the hook rig which the ship had, fastened to a long rope. I soon had the shark on, and set the large shark hook well into his jaw. He was altogether too large for hoisting aboard, as his weight would surely tear out the hook. He would, after being hooked, swim under and about the ship, but did not exhibit any remarkable ferocity or fighting qualities, and would submit, with the aid of several of the crew, to being hauled up along-side the ship, but that was all that could possibly be accomplished with him. The captainfriendly disposed-got out his long shark and porpoise harpoon, which had a long iron shank of eight or nine feet in length. To the end of the harpoon a stout rope was attached. I can see Captain Homer in full remembrance now-after the many years which have elapsed-standing on the bulwark of the ship's side as he cast the harpoon deep into the shark, which had quieted down considerably, and lay supinely along-side. The penetration of the harpoon, complete as it was, seemed to affect the coarse sensibilities of the shark, and he gave such a wrenching roll-over of his body, the captain meantime holding on the extended wooden handle of the harpoon iron, to which a rope was attached, it bent over the iron part, so that it became a gigantic hook, as it were, of the harpoon through the shark's body. The shark then made a run, but, with half a dozen men holding both the hook and harpoon ropes, he was soon brought along-side. A sure prize he was, and 


\section{A Sportsman}

small insurance money would have been paid out to guarantee his gracing the ship's deck.

The ropes were run over blocks, andthe hoisting commenced on both ropes. The weight was so excessive, with over a dozen of the crew on the hauls, that the captain thought it expedient to make a sure thing of it by bending a noose around the shark's tail. This was done, and over the three blocks the sailors pulled merrily on the ropes. The shark had almost reached the height of the bulwarks when it was observed that the hook, hauling too heavily upon the shark's mouth, was tearing out. It did. The additional strain upon the great harpoon hook began to straighten it out, and finally it came out entirely. Fortunately, we had the noose rope on the tail. Fortunate, indeed; when horrors! that began to slip; and, a shark's tail not being of that cross-cut variety which the tunas and the blackfish have, slowly oozed through the noose, and our shark made a header into the green sea, from which he never appeared to our view again.

Moral: Don't count your fish until they are strung or creeled; and then you may not be sure of them, as a visiting chap at the Rangeleys last year found when returning from a brook at twilight with a creel full of fish. Passing through a path in the woods, he heard a noise behind him, and saw a huge bear rising up on his hind feet. Suspecting the cause, he hastily threw down his basket, and legged with good speed away, finding the next morning only his torn-up empty basket and nothing else.

Among all the salmon I caught off Monterey, I never saw one that appeared in thin flesh: all plump 
and full, indicating that the sources of food supply are most plentiful. As the various fishes which they prey upon, the anchovies and sardines, are not deepwater fish, or the squid, it is pretty clear that the salmon do not go very many miles from the shore, probably not more than a hundred, or that they frequent a depth greater than fifty or sixty fathoms. There are instances where they have been caught at sea at a depth of from twenty to thirty fathoms by baited hooks, at different places up and down the middle and northern coast of California, but not at a greater depth than mentioned.

It is not likely that the king salmon, or chinook, those of the San Joaquin and Sacramento rivers, ever go more than a hundred and fifty miles from the bay of San Francisco, and they are never seen more than a hundred and twenty miles south of the bay. Although identical with the chinook of the Columbia River, seven hundred miles north, they are distinctive in weight, those of the Columbia River averaging four pounds heavier in weight at the canning works over those of the Sacramento and San Joaquin rivers.

How the salmon find their way to the several particular streams where they were hatched out, and which they occupied in their juvenile days, I will explain in some later references to fishes and their ability to find their way through the sea, and this through the confusion of the waters of the bays, too extended to consider at this moment.

The salmon in the sea appears to be quite fearless and indifferent about boats and fishermen, probably never having seen any before, and if considered at all, would probably suppose them to be some sort of fish, 
and moderately avoid them on that account. They often pass by the boat not far from the surface, and occasionally follow up a hooked salmon near the boat as trout and bass will, though not frequently, and I have occasionally observed four or five salmon following up my shred of a bait when reeling in to replenish. When fifteen or twenty feet from the boat they would turn off in disappointment, which I would endeavor to relieve as much as possible by speedily throwing out a fresh bait. A rather exciting moment for a fisherman.

I have examined the stomachs of a great many of these salmon, not only of my own catch, but at the salting works at the Monterey pier, California, and have very seldom found any empty. The predominating food I have found more of squid than anything else; next anchovies and sardines. These appear to be the principal food at the bay when the waters are full of them. I found also varieties of small fishes, smelts, cods, blue-fish, flounders and others. Occasionally I have found the stomachs packed with shrimps, which swimming in clouds could easily be scooped in.

The stomach of the salmon does not have the distention apparent with other members of the Salmonidee family, not exhibiting the swollen aspect seen often in trout, which, gorging to the limit, will still take the minnow when only a portion of it can enter the stomach, and with the tail part protruding from the throat will often as eagerly strike at the fly as if half famished.

It is clear that the salmon at home in the salt water is an indiscriminate feeder upon any kind of small 
fishes which come in its way, and will strike at any moving object not too large for swallowing whole. Although I caught some salmon with a spoon, I did not find this offering taken as readily as fresh bait, and a large fly would be readily taken if trolled at a depth.

The salmon come in at Monterey usually in the first part of June, and almost wholly disappear by September, though an occasional salmon may be picked up out of season.

In a dead calm, or in the middle of the day, the salmon strikes will almost cease, and the favorite hours for success are from the break of day to nine o'clock, during which hours I did most of my fishing. One cannot be too early for them. The mornings during the season are almost always calm and breezeless, and generally foggy, often so much so that one going out from the Monterey pier may have no index of his course but the mellow sound of the buoy bell, two miles out, which at intervals strikes from the rising and falling of the ground swell. This bell I have been guided by, and have listened to so often that, for a long time after my fishing experiences at the bay, I have imagined I could hear its distant soft and weird sound in the stillness of the night, when many miles away. About this buoy was a favorite reach for the salmon. About eight o'clock the fog, however dense, would generally drift away landward from the almost invariably westerly breeze, which would give good sailing speed for home. This breeze would occasionally be so stiff as to kick up a rough sea, not pleasant to one inclined to sea-sickness, a complaint, however, which 
I did not experience, nor the habituated fishermen. But even with a rough sea the fishing would hold good.

Many destroyers beside man are among the salmon - the sea-lions, seals, and sharks being most conspicuous, with occasional visitations of porpoises, killers, tunas, and grampuses.

One morning in a dense fog an immense sea-lion rose up from the water just ahead of my boat with a salmon in its mouth, a rather appalling sight from his close proximity, but harmless, as they have never been known to attack men or boats, although a fatal incident occurred in the bay the year before my fishing, when a large sea-lion became entangled in a fishing net-not an uncommon event-and, while being struck at by one of the netters at close quarters, seized him by the thigh, and carried him down, with fatal result. The seals are plentiful and will occasionally cut off the salmon while it is being hauled in.

The fishermen dispose of their fish almost wholly for moderate prices at the Monterey pier, where salting works are established, receiving for their salmon from three to five cents per pound. Their other varieties of marketable fishes are handled also by the salters, who pack and forward to dealers at the various markets.

It is observable that the schools of salmon are comparatively uniform in weights, in one locality running from twelve to twenty pounds, and in another from twenty pounds up; and off the coast at Santa Cruz, twenty miles north of Monterey Bay, they run lighter than at the latter locality, where grilse are much more plentiful.

It is a feature apparent at Monterey Bay that the 
male salmon largely exceed the female, the latter but little exceeding one quarter of the whole. This is rather singular, considering that at the canning works the sexes are about equal.

I heard accounts of large salmon at Carmelo Bay, twenty miles south of Monterey, a place not much frequented, being without boats and convenient railroad facilities for shipping, and therefore not desirable with the fishermen, on account of its distance away. At this bay is the outlet of the Carmelo River, a mountain stream which I have before mentioned as a resort for the steel-head trout, so plentiful at certain seasons. But one from the bay view would hardly suspect the existence of the river beyond the half-mile of beach through which it cuts its way in large volume during the annual winter rains, but now in the salmon season the mouth is effectually sealed up by the bankedup sand, through which but a moderate amount of water slowly seeps. The bay is small, being about two miles in width, while the water is very clear and deep. The region is quite deserted excepting for a very few Chinese huts and adobes. Prominent, however, is the old Carmelo church some distance inland, built many years ago by the Jesuit padres but fairly well preserved, where services are occasionally held for the benefit of the few remaining inhabitants, representing a mixture of Mexicans and Indians scattered about the region.

I had my boat and two men go down there in advance, and by rising at the early hour of three o'clock at the Del Monte hotel could drive down there in 
season to get the early fishing, where I had several days of notable success.

Few bays could be more beautiful and romantic than Carmelo-resting between two bold rocky promontories, on one of which, back from the shore, are groups of a very rare tree, the true cedars of Lebanon, not found, I believe, elsewhere on the American continent. These cedars throw out their branches in a most curious and grotesque manner, and would instantly attract the notice of a passing tourist by their remarkable appearance, so different from anything seen before. When I passed them in the starlight hour-as I did several times in early morning or late evening-I never failed to be strongly impressed by their weird and fantastic shapes.

I had an experience at Carmelo one day with the salmon which I doubt if any other mortal ever witnessed the equal of. It was not yet light after my drive from the Del Monte when I passed from the remnant of an old wharf among the rocks on the south shore of the bay to my waiting boat. The morning was fogless, with a light breeze from the west. A few pulls brought the boat over an immense school of anchovies near the surface, with which our jig of a short rod and ten feet of line, set with a leaden sinker on the end and half a dozen bare hooks, soon filled our bait bucket. This method is followed for obtaining bait, by dropping down the line and pulling it up quickly, when bushels of anchovies and sardines can be obtained if over a swarming school, as plentifully found in the bay waters during the season.

The long, heaving green waves from the Asiatic 
coast were about to feel their first check on the California shore, and among those moderate swells were thousands of salmon full of lusty strength, and silver-glistening, gliding amid this immense mass of anchovies, which scattering and demoralized vainly sought escape. As it grew lighter the salmon could be seen in rapid motion near the boat, and many breaks and whirls were observable near the surface. The birds were already there to seize the distracted anchovies when within reach, shrieking with discordant gabbling notes their exultation, the only sounds which broke the quiet of the morning.

The water was clear and attractive in its bluishgreen hue. Down many feet could be seen the silvery anchovies in restless motion, easily followed by their flashing brightness. Among them were the salmon, seeming at play, but as wanton as that of the tiger with its victim. Blue flashing streaks occasionally passed near the boat. These were the salmon in passage, and now and then one would break fairly out of the water, but not with the playful leap as seen in fresh-water pools, but breaking from one wave to another in headlong pursuing flight. This scene continued directly about me for an hour, and my men and I were the only witnesses, on the placid waters of this beautiful bay, of this interesting scene which many salmon fishermen would have given so much to see.

Once a salmon came up head-on, vertically, several feet out of the water, close to the boat, so near that it seemed as if it would come in. It was a bold and vigorous rush from below, undoubtedly for an anchovy above him. It was an exciting moment, 


\section{A Sportsman}

for I had a large salmon on my line, which was wild with fright and frantic struggles. As I brought my salmon to gaff, my lead sinker on its short piece of line, some thirty feet above my hook (as I had not then adopted the improved method of connecting it near the bait), was seized within six feet of the boat by another salmon, and torn away. I saw distinctly in the clear water as I was reeling in my hooked salmon, the rush of this second one and its quick strike, and the tearing away of my sinker near the surface, suspended on a light piece of line, relieved me from the necessity of taking it off, which I was about to do. I have had salmon strike at my sinker many times, and this was the third instance of having it carried away, showing the disposition of this fish in its normal condition to strike at moving objects. Losing my sinker in this instance, I dispensed with it for a while as the salmon were about so plentifully, taking in several with my bait near the surface.

I could not, at this exciting period when salmon were so plentiful, but regret the time required to fetch them in, requiring from ten to twenty minutes for each. So I had to stop playing my fish, while the great body of anchovies moved on toward the beach shore of the bay, driven on by their relentless pursuers, followed by the circling clouds of shags, muirs and gulls, and less rapidly by my boat impeded by the necessity of fighting hooked salmon. But we followed on, finally into the jaws of the ground swell, where for half a mile in length on the sandy beach the salmon held the anchovies for at least two hours. Back, probably, from the advancing 
school of pursuers, were other contingents of breakfasting salmon taking the places of those which had made their fill, and no cessation of quick striking occurred until the sun was an hour high.

Many of the anchovies in their fright were driven up upon the sandy beach, where a long line was visible of flopping fish, of which, however, the most managed to regain their native element. At eleven o'clock, when I ceased fishing for the time-as the salmon had retired to deeper water-I had seventeen in my boat.

In the afternoon I renewed my fishing, securing twelve more, making a total of twenty-nine salmon which gave a total weight of over five hundred pounds. My largest fish of the day weighed thirty-three pounds, and my smallest thirteen. I was satisfied, and had my glut of salmon, a carnival of fishing I was sure I would not soon see again.

While my result of the day was large, I lost more than ever before in proportion to my catch, owing to careless handling arising from the excitement occasioned by such a plentifulness of strikers. It was a dark record against my skill. I lost twelve fish which had been hooked and played from five to fifteen minutes. One large fish, despite all my exertions, ran out all my line and parted it. One salmon-a very large one-sprang out of the boat and escaped after being gaffed, before receiving the usual quietus of a blow on the head.

I had a wagon down from the Del Monte which conveyed all my salmon to the hotel, and I passed the following day in forwarding salmon to San Francisco and neighboring points where I had friends. 
Many curious incidents occur with fishermen which seem almost incredible, some of which are so singular as to create a smile of incredulity upon the relating. I have had many such, but one occurred of an amusing character while I was salmon fishing accompanied by a friend, who after I had taken in a few salmon, and had a following stripping of bait occur, and no fish, bantered me as I put on a fresh bait to wager that I would take in a fish on the following cast. I said I would take it for a box of cigars, that I would take in a fish of some kind, not confining myself to salmon, on that trial. I had a good strike but failed to hook my fish, and I knew by the way my line eased up that I had lost my bait; so I slowly reeled in, trusting that possibly some mere shred of bait remaining might lure on some straggling wanderer. But as the end of my line appeared, and the hook looked bare, my friend Sprague gleefully claimed the bet. But as I lifted it in over the side of the boat I observed something of slight form attached to the hook, and upon our close examination it was seen that I had won the bet, for hanging upon it was a minute codfish of not more than an inch and a half in length, which was hooked squarely in the mouth, the point of the large hook coming out through its gills. In reeling in my line and bare hook, this minute specimen had probably been swimming along in an opposite direction, and the point of my hook had struck it squarely in its little mouth, securing for me my wager. I have the little chap now in alcohol in a small bottle, as a memento of this occasion.

It may be claimed, by those fishermen who are so wedded to the artificial fly, that trolling with a 
spinning anchovy or sardine is not the proper lure for the king of fish, but it may be a question if such a view is not of the fanciful and fantastic order, rather than the resulting conclusions of the experienced all-around fisherman, who, disdaining an unfair advantage over his game, does not decline the acceptance of a lure which may to an extent, if stolen away, compensate for the risk taken.

As the autumnal rains commence in California, swelling the tributaries and main streams of the Sacramento and San Joaquin rivers, emptying into the bay of San Francisco, the salmon take leave of Monterey Bay and its vicinity, but they are usually succeeded by new schools from the outer sea, which in turn depart, and are followed by more, until well into September, although an occasional salmon may be picked up about Monterey during every month of the year.

I have before mentioned that these salmon, as seined at the Sacramento and San Joaquin rivers, are well proved to be those of Monterey, as their average size is similar, and distinctive from those of the Columbia River in Oregon, several hundred miles north of San Francisco, where the salmon average several pounds heavier.

Their arrival at the river seining nets is timed at three days after their departure, as I have observed by the news from the river canning works, showing that they leisurely make the distance at the rate of thirty miles a day, or rather each night, as the latter is the time of their journeying. It is observed that when the movement takes place, from a reach of twenty or thirty miles in extent along the coast, 


\section{A Sportsman}

all go, excepting a few stragglers, showing a concerted action. It is interesting to note that in the bay of San Francisco a large number of grilse are found, which remain the larger part of the year, and are freely caught in particular localities with shrimp bait, and no other locality is known where grilse can be caught in a similar way.

The distance from the landing at Carmelo Bay to the pier at Monterey is twenty-five miles. I concluded, after completing my fishing at Carmelo, that I would take the passage in my boat from there on its return, that I might try the salmon fishing on the way in deep water upon the exposed ocean coast. I had a rather exciting adventure.

I drove down in the early morning from the Del Monte, and the day was very promising for a fair breeze to sail up with, from the west. We started along favorably and I found the salmon, as I expected, in the outside waters, taking in several at the commencement. The breeze freshened up a good deal, giving us all our sail and boat could carry, with the sea continually rising; and we, sailing along in its trough, had to turn west repeatedly from our northerly course to avoid the combing waves which threatened to swamp us. We, however, kept on, though it would have been better to have returned to Carmelo, for the tide was setting in toward the rocky shore, where no harbor of refuge existed.

The breeze continually freshened, most unusual for the season, and finally increased beyond the capacity of our sail, reefed as we had it, to withstand, and we had to take it in, and depend upon our oars for getting on. So we pulled on for hours in 
our heavy boat with the waves increasing in magnitude, compelling us to swing around head-on west every time a top wave would reach us, to keep out the water. As it was, we were soon drenched, and bucket bailing was necessitated.

When we reached half way, we had our worst call off the string of seal rocks and resorts of sea-lions, which give such picturesque effect to the seventeenmile beach drive of the Del Monte. It seemed as if the strong inflowing tide and the gale would set us into this foaming region. Despite the threatening conditions it was a beautiful sight, on this day of sunny brightness, with the transparency and various hues given to the oncoming green waves which rode in majestic order, with graceful crests. Upon the other side were the spouting rocks, and the foaming washes of the broken waves. It was a case of being between the devil and the deep sea.

Here my most aged boatman, worn out with strenuous labor, suddenly pulled in his oar, and swore he would not pull another stroke to save his life, naming two of his former associates who had lost their lives on a similar occasion upon the seal rocks. I quit my bailing for him, and took the oar. We mastered Point Lobos, but did not dock our boat at the Monterey pier until eleven o'clock at night, having been fifteen hours in passage.

IT was my fortune to visit the Territory of New Mexico a number of times, such visits extending over a period of twenty-five years. My first visit was during the building of the Atchison, Topeka and Santa Fé railroad, when the conditions of the Terri- 
tory were much unsettled, and when no other section of the country could have equalled it in lawlessness and rough life. In relating the experiences I had there, which were fraught with so many unpleasant incidents, which I do not look back upon with particular satisfaction, I have some doubt if my readers may not look at them with some degree of incredulity, and especially with wonderment that I should have submitted myself to such experiences. But we do not know what may befall us in our movements, and once engaged we are usually necessitated to keep on, and my recitations will be of simple facts as they occurred.

The Atchison, Topeka and Santa Fé railroad was then building rapidly along the Rio Grande, having been diverted from its proposed direction at the town of Pueblo, in Colorado, by the opposition of the Denver and Rio Grande railroad, which claimed the right of way up the Arkansas River into the mining regions of the Rocky Mountains. This route was through a narrow gorge, where only space existed for many miles for one railroad, and the dispute which occurred led to an array of armed forces of several thousand men, which threatened the peace of the whole Territory, and was finally settled in favor of the Denver and Rio Grande railroad by its payment in compromise to the Santa Fé railroad of about a million dollars.

Upon this settlement, the latter road, being compelled to go somewhere from the weight of its momentum arising from the capital pledged and the eager spirit of building which then prevailed, pursued its course from La Junta, east of Pueblo, near the New Mexico line, into that Territory, which, seemingly, was about as sterile and unpromising a region as could 
be presented, especially in contrast with the fertile and promising State of Kansas, which the road had passed through.

The Territory of New Mexico is bordered on the south by the republic of Mexico, and on the north by Colorado, and on the west by the Territory of Arizona, and is larger than all the New England States with New York State combined. I had little idea on my first visit I should have so much to do with it, which occasioned many other visits.

The Territory presents the most barren aspect of any region in the republic, since the Great American Desert, depicted upon the maps of our childhood as extending over the immense area from the Missouri River to California, has been chased down in limits to New Mexico, Arizona and Nevada; and the mighty plains of the supposed desert between the river and the Rocky Mountains produced last year, of corn alone, more than sufficient, if packed in a continuous train of cars, to reach twice around the world.

Excepting about the Rio Grande-which spreads out extensively in its passage through the centre of the Territory, and along other streams tributaries of the Rio Grande-but few limited cultivable tracts exist without irrigation. A large portion of the territory consists of dreary plains and mountain ranges. The population was, and still is, largely Mexican, with perhaps one-tenth Pueblo Indians, living in villages of their own, and perhaps as many Apaches, Navajos and Mescallaros. The Territory is less pronounced in mineral values than any of the western mountainous States, but has a most healthful 
climate, and abounds in many mineral springs of undoubted curative qualities.

Could the ancient history of the region, now unknown excepting from the traces left, be recorded, it would be most interesting, as probably with the lower part of Colorado; judging from the ruins of large stone community buildings, cave-dwellings, towers on commanding hills, and extensive irrigating canals and aqueducts, it was likely at one time to have been more densely settled by the predecessors of the present Pueblo Indians, known as the Anahuacs and Toltecs, estimated by the great Von Humboldt in his Systeme du Monde to have settled here in the year 648 and to have flourished in this region for several centuries.

From these descended the Aztecs, who, in the eleventh century, founded the City of Mexico at Lake Tezcuco, as found by Cortez at the time of the Spanish invasion. This conclusion was also arrived at by the early chronicler Abbé Clavigero, from the established traditions of Mexico that the south-flowing immigration into Mexico, and beyond to the land of the Incas, proceeded from the region now known as New Mexico and Arizona. Here Coronado, the lieutenant of Cortez, made his famous expediton, in $\mathrm{I} 540$, in search of the traditional kingdom and seven cities of Cibola, where greater wealth was expected to be obtained.

But this is not a history of New Mexico and Arizona, of which I could give many pages, and have given elsewhere in publications.

The numerous cave-dwellings, difficult of approach, and the watch-towers, and numerous ruins of buildings 
where the entrances were high up, and only reached by ladders, which could be withdrawn, all indicate that these were periods in the history of this Toltec and Anahuac habitation when human life was in great peril from warlike tribes, and show that in the two centuries preceding white occupation a very considerable extermination had occurred; and even in the nineteenth century the accounts of massacres and spoliation were of an extremity to which those of the early settlers of New England from the Indians were of light circumstance in comparison.

I have had occasion to search the church records in New Mexico by employed assistants to a large extent for tracing genealogical descents, to ascertain existing and unknown interests. After the Spanish occupation, large tracts of land were awarded by the kingdom of Spain to Spaniards as an inducement for their settlement in the new regions acquired, which were largely availed of. These settlers had no difficulty in dominating the Pueblo natives of New Mexico, who were industrious and hospitable and non-warring, as of to-day, and united with them in mutual defence against the warlike tribes who, from prehistoric times, committed great ravages. Under the customs of the Catholic faith in New Mexico, most particular records since I 700 have been made in the church archives, of births, deaths and marriages, and the details of such in many instances are given with extended references, faithfully transcribed by the official recorders, so that a remarkably accurate recitation occurs of families, of deaths and na mes of relatives, and causes of death; and I have 
been struck with surprise to observe the large numbers who had been killed by Indians-numerous instances where whole families had been so destroyed, and all families seemed to have suffered in this respect. I am acquainted with a young man who, out of twelve uncles and aunts, had eleven killed by Indians. Until the Apaches were lately secured upon a reservation, and the Navajos some time before, yearly massacres were common, but happily relieved in recent years.

The Spaniards, ever cruel and aggressive, and feeling secure in their possession, finally carried their inhuman treatment of the Pueblos to such an extent that they rose in unanimous action on the I3th of August, in I680, at a given signal, and very nearly exterminated every Spaniard in the region, amounting to several thousands-men, women and children. This was a most remarkable revolution, since no intimation of the unanimous uprising was given, excepting that of two servants of the Spanish governor at Santa Fé, two days before the uprising. The governor had barely time to concentrate his small military force of a few hundred, when he was surrounded by several thousand natives, by whom he was harassed for several days at great peril, and from whom he was compelled to retreat as a last resort, and succeeded in reaching Isleta, some sixty miles south, where he was re-enforced by several hundred more Spaniards-the only surviving ones in the region who had escaped massacre. Thus supported he sustained himself for a while, when a further general retreat was made on foot down the Rio Grande two hundred miles to E1 Paso, which he 
succeeded in reaching in a most inclement season, largely diminished in force, from suffering and privations of exceptional character. Here he made a sustained stand, being re-enforced by a small force from Chihuahua, but insufficient to sustain an aggressive movement.

Thus was New Mexico relieved from oppression, and the natives, imitating the iconoclasts of the Dark Ages, proceeded in the destruction of all that pertained to Spanish dominion. All the priests had been killed and all the Catholic churches and crosses erected were levelled to earth. All the manuscripts, documents and records left in the archives of Santa Fé were burned or cast to the winds, destroying all history of the Spanish rule for nearly a hundred years.

The mines, which had been worked by the enslaved Indians with such suffering, were covered over and obliterated as much as possible, many of which are still lost.

More than ten thousand who had been compelled to renounce their religion for the Catholic faith, and had received the sacrament of baptism from a sprinkling broom of expiation, renounced their hopes of salvation under the cross, and returned to their ancient forms and superstitions.

While the Spanish governor held E1 Paso on the Texas line for a period of two or three years by reenforcements from Mexico, and made occasional forays up the Rio Grande, little material benefit was gained, and he found it necessary to withdraw to the City of Mexico. This left the Pueblos in full possession until the year I695, when the country was retaken most effectually under General Zapata, with 
a large force, and was held securely until I8 37 under Spanish dominion. At this period an insurrection among the Spaniards occurred, the dissatisfied element being largely aided by the Pueblos, and by raids from the Texas Comanches, who massacred and pillaged alike the Pueblos and Spanairds. Then the Apaches and Navajos, powerful tribes, inflexible foes of the Spaniards, were aroused to action and committed frightful ravages, and the Spanish government trembled in the scale, but finally sustained itself until the Mexican War of I846, when General Kearney made his memorable march with his regiment across the continent to California, subjecting New Mexico and establishing a provisional government at Santa Fé.

Then came the cessation of the Mexican War under the Guadalupe Hidalgo treaty of 1848 with Mexico, and the acquisition of that enormous stretch of country from above Texas and the Mexican border to British Columbia, from out of which so many States and Territories have been added to the American Union. This seizure of territory in its importance has never been equalled in the records of history as an aggressive exhibition of power shown by the United States over a comparatively defenceless foe.

Our party followed the railroad down to about the middle of the Territory, and left it at the Isleta Pueblo for the purpose of making our way west to the Zuñi Pueblo, a hundred and twenty miles or more. Our party comprised five, including one guide, who accompanied us with a pack mule, carrying supplies and cooking utensils. Mounted and well armed with repeating rifles and side arms we felt pretty well secured for an advance through a mountainous and 
desert country, quite unsettled, excepting by a few sheep- and cattle-men, sparsely distributed in the few limited localities where springs and feed were found. The greater part of the region consisted of mountains and sandy plains of barren aspect.

Rumors of troublesome Indians being about put us on our guard, but such rumors were more or less chronic in those parts, and we did not consider them a sufficient deterrent, being more afraid of the reckless white element, then plentiful enough in the country, and which we expected soon to get out of reach of. But we made a bad reckoning in respect of Indians, as we found out the first day.

We resolutely started out from the little settlement of a few houses at an early hour, and fording the Rio Grande ascended an elevated plateau, which we crossed for seven or eight miles to a range of high hills, which extended for some twenty miles, necessary to cross before reaching an open country where we expected to camp for the night. There was no timber, and we kept as much as possible on the ridges and the open to avoid a possible ambuscade, keeping out our guide in advance, with his pack mule in the rear. It was near noon, and we were expecting to halt shortly for our midday meal at a spring our guide knew of.

We had been told to look out carefully at this spring, for if there were any Indians about they were likely to be in that vicinity. We saw no signs, and held up near the spring, which was at a little sloping hillside, and from which, on one side, arose a somewhat precipitous rocky bluff, perhaps two hundred feet high. As we dismounted I happened to 


\section{A Sportsman}

look up to the top of this bluff, and thought I saw a flashing gleam of sunlight reflected from a metallic substance and called attention to it. We all then saw flitting for a moment the forms of two or three Indians concealing themselves behind some projecting rocks at the top, and a gleaming rifle barrel apparently pointed directly at us. The appearance we then exhibited is more ludicrous at this moment, in contemplation, than it was then. Our horses, mine being already picketed, were abandoned. Our guide and two others of the party, with their rifles, got behind the only three small trees adjacent, and Captain Slawson, a mining expert I had taken along-who was afterwards killed by Indians upon another excursion we made, further south-more experienced with Indians than any one of us, excepting our guide, endeavored to get behind his mustang, which partook of the excitement we felt, and insisted upon getting on the wrong side. My own gun, being near my picketed horse, I had no time to regain, and seeing near a prospecting mining shaft about fifteen feet deep, with a log down it with steps cut for descending, and feeling that I had no moments to spare, I rushed down it for temporary relief; but not to the bottom, for I heard an ominous sound altogether too familar to my ears, which arrested my further progress, and looking down at the bottom saw what at first sight I thought a curled ram's horn, but immediately saw was an enormous rattlesnake coiled for action, with vibratory tail. It is needless to say I stood at rest, safe for the moment from both enemies.

Rattlesnakes are very plentiful in some parts of New Mexico, more so than I have ever seen else- 
where, and occasion more or less loss to cattle, though seldom striking men, who are warned of their proximity by ominous rattling, and they have a habit of falling into old mining shafts, and these will hold them from escape for weeks, until death finally gives release.

Hearing no shots I cautiously looked out of my haven, and saw our party on guard, and that no firing had occurred from either side. This state of suspense continued for a while longer, and from Slawson's not having been fired at while getting control of his horse it was concluded that we had better pull out as soon as possible and retrace our way to the Rio Grande. Securing our horses we all mounted and retired without molestation.

It was our view that the Indians were either out of ammunition, or limited in number, or, if in force, were opposed to taking the risk as situated, but might attempt to head us off elsewhere on our route. We therefore, without indulging in the refreshments we had expected, made as rapid time as we could back again with due caution, and felt much relief when we arrived on the open mesa, where little risk of being ambuscaded would occur.

We found, after arriving at the Rio Grande settlement, fresh reports of Mescallaro Indians, a branch of the Apaches, having been heard from in the mountains we were in, and also that the Apaches were off their reservation below in Grant County, and were committing many destructive raids. This convinced us it was not prudent to attempt our visit to the Zuñi reservation, remote from railroad and settlements of whites; and as the Santa Fé railroad was just being completed to Deming, further south, 
to meet there the Southern Pacific from California, we concluded to push on, and from Deming go on to the west for fifty or a hundred miles, where glowing accounts of antelope, deer, wild turkeys and bear, as well as of mineral deposits of great value, would be realized.

But we found these reports to be less than depicted. There poor Captain Slawson met his death, a most fearless man, and reckless of danger. He was induced to join an excursion into the Mogollon range of mountains, where the Apaches, in detached parties, were on the warpath. The party was composed of four-Captain Slawson, J. P. Risque, Jack Magruder and G. P. Smith-all acquaintances of mine. I was invited to accompany them, but would not for a moment consider it under the existing conditions.

Magruder, the only survivor, gave me an account of the result. The second day out from Silver City, while passing mounted on trail through a ravine, and while approaching a group of small trees and underbrush, a remark was made by Magruder that it was a good place for Indians to hide in. No sooner said than Slawson, being in the lead, answered: "There are your Indians, Jack," and at the moment they were fired upon. All but Magruder fell mortally wounded, shot through. A dozen Apaches rushed upon them, firing as they came. Magruder, being untouched, had his horse fall with him, from which he disengaged himself, and with his repeating rifle rushed to the shelter of an adjoining boulder, being repeatedly fired at, but escaping all the bullets. From the boulder he held the Indians off and managed to work his way up the hill among the rocks behind him, escaping all the shots; and, being a good shot 
himself, and abundantly supplied with cartridges, either killed or wounded several of the Indians, which enabled him-though at great risk-to extend the distance between them.

Over an hour he held them off without being wounded, when he observed at a distance two of the Indians making a circuit around to get at his rear. He confessed to feeling that his hour had about come, dark was approaching, and it became a serious question if he could hold out long.

Looking back in his retreating, he observed the cribbing of a miner's tunnel up the hill beyond, for which he made a great run and succeeded in reaching it. Upon entering this tunnel he was surprised to see a dim light a long distance in, which he made for, and was still more surprised to find two miners at work there, entirely oblivious of the firing which had been going on. Both were armed, and when acquainted with the situation put out their candles and awaited the issue, intently watching the mouth of the tunnel for dusky forms. But none came, and in a silent hour of the night the three men stole forth to the cabin of the two miners, half a mile off, which they found undisturbed, and from there made their way to the nearest settlement.

From Isleta we pushed on by the freshly built railroad to Deming nearly to the south end of the Territory, arriving there at an early hour. Here, on this day of our arrival, the important connection of the Santa Fé railroad was made with the Southern Pacific railroad from California - a meeting of two great railroads which for many months had been pushing on for this connection. 
Thousands of workmen had been employed, and a rivalry had existed for an advantage of each railroad over the other. Here a meeting had occurred on the level plains, far from any settlements or towns, at a spot destined to be one of importance; not only from the connection of the two railroads now meeting, but from the junction of two other railroads from the south, those of the Galveston, Harrisburg and San Antonio and the Texas Pacific.

A fifth railroad has since been connected at Deming, built by the writer with some associates, proceeding north to Silver City. No spot in the region could have been more advantageously selected, having many mountainous peaks within a range of from forty to fifty miles, which seemed in most instances to have been pushed up from the level plains without the accompaniment of foothills.

Water, so wanting in New Mexico, is found here in bountiful quantity and good quality, but a few feet beneath the surface, and the surrounding soil is superior for cultivation.

The situation was a very interesting one upon our arrival that sunny morning; not only from the large number of men employed, but from the importance of the railroad connection, unequalled before in the annals of railroad building, with the exception of that of the Union Pacific and Central Pacific roads at Promontory in Utah in 1869. Before we reached the town we found a large force engaged in ballasting the newly-laid rails, and many teams passing up and down the track.

At the connecting point, from fifty to a hundred tents were pitched, with a motley collection of teams, 
representing the caravans which had been moving along with the building roads, now meeting at a given centre, which was supposed to be that of the new town.

Many of those teams represented the feature which has been represented in the vernacular of the country as "hell on wheels," comprising those convenient vehicles accompanying railroad building, to accommodate men, horses and mules with food, and others fitted up as well as tents, to supply the superior animal with spirituous refreshments and attending recreations in the way of cards and dice.

There were long rows of board tables, convenient in their light construction for removal, loaded substantially with delicacies usual on such occasionsbeans, shoulders of beef, fried nuggets of bacon, slabs of perfectly fresh bread steaming hot, pots of coffee, and various other attractive condiments.

Many of the tents were fitted up as drinking and gambling saloons, from which proceeded the melody of violins and flutes, with accordion accompaniments. The keepers of many of these adjunctive resorts were of the most abandoned and reckless cast, as much so as one could expect to find, and one could see in the vicious lines of their faces, and beady eyes, that they had reached the bottom lines of desperate life.

Two outfits of this character had now come together, composed of the lowest order of ruffians to be found anywhere, and knowing that their opportunities for plunder were about to vanish with the paid-off, departing laborers, were displaying unusual activity in their last efforts.

No sooner had we landed than we were surrounded 


\section{A Sportsman}

by a score of hard-looking characters, who viewed us with interest, and in probable expectation of gaining profit from our advent. Proffers of assistance in carrying our hand-baggage were given, which we declined, holding firmly to our possessions. We had nothing to do but look about and patiently wait for the conveyance we had telegraphed for two days before to Silver City, fifty miles distant, which we assumed would arrive during the day, to carry us on to Hudson. The latter place was situated twenty-five miles distant, midway between Deming and Silver City, the only settlement on the route where a rough sort of a hotel existed, carried on by Hudson, a long time settled in the region.

Two long freight trains from California stood on a hastily constructed siding, which were being unloaded. One of the trains had a car-load of second-class passengers bound east, and an express car. The latter had been fitted up as a telegraph and business office and here was our first introduction to Tucker, the express agent, a stout, resolute-looking man, who had a pair of large navy revolvers hanging from his hip. To him we were indebted for attention, and his appearance gave confidence. He was busily engaged in the duties of his work and, with the telegraph operator, appeared to be in full charge of the railroad freight and express business.

Acquainting him with our situation, waiting for our transportation, he permitted us to deposit our baggage in the end of his car, promising to take care of it. It was evident that he was well fitted for the position he occupied, and perfectly fearless of the crowd which honored us with their pressing attentions, and we saw 
clearly that the assemblage stood in appreciative awe of him; and he had undoubtedly a contingent force of railroad employés who could be speedily called upon for aid whenever it might be required.

$\mathrm{He}$ was a noted and remarkable character, this Tucker, as will afterward be seen from what I shall relate of him, as I had occasion to see and learn much of him after becoming well acquainted during my many visits to New Mexico.

Together we sauntered about more or less, keeping well together and on guard, continually followed by hangers-on, and one of our party, Adams, a young man from Springfield, Mass., met with two adventures not pleasant. He was somewhat difficult to keep in line, and incautiously entered one of the tents we were passing-where some minerals were displayed on a table near the entrance. The interior was a drinking saloon (which he had not noticed), and no sooner had he entered than a burly ruffian invited him to throw dice for a small sum, which he declined; and, having satisfied his curiosity, he started to go out, when the ruffian blocked the outlet and said he must stand drinks for the half-dozen inmates. Alarmed, he did so, as the easiest method of escaping, just as we were returning to look for him, and related his amusing experience. Somewhat startled by the occurrence and having several hundred dollars about him, and in anticipation of a possible hold-up, he took out his roll of bills when unobserved, and tucked it down next to his heel in one of his stockings. But we were not held up, and at night when looking for his roll of money he found it had worked out and was lost, and he never saw it again. 


\section{A Sportsman}

Noon came, but no team for us, and we took our dinner at one of the tables, beginning to feel apprehensive that we might be left over for the nightnot a pleasant prospect. Four o'clock came, but no team. It was time for some action and I consulted Tucker. He suggested that we should strike out among the straggling stunted growth of bushes in the neighborhood and camp there, as his car and every accommodation was crowded full. A Southern Pacific palace sleeping car stood on a siding about a hundred rods beyond the settlement, left by some of the minor officers of the railroad, who had gone off to Silver City for two or three days, and had left strict orders that it should not be occupied during their absence, and no one about had any authority to allow it. I found the telegraph was working direct to San Francisco, and knowing Mr. A. N. Towne, manager of the Southern Pacific, very well, I concluded to try and reach him on the wire and see if I could not get permission to take the car; concluding, if I could not get an answer in season, that we would strike out for the bush at dark, and locating first temporarily would at a later hour move off a mile or more still further away, where we could rest safely until morning.

As dusk came on we were about ready to move out, when an answer came from Mr. Towne giving us the car. Taking our hand baggage, and with our telegram certified to by Tucker, we started off for the car, escorted by a body-guard of about a score of ruffians. We found the car firmly locked, with its curtains closely drawn down, in charge of a colored porter, who paid no attention to our knocks and 
banging on the door, which our solicitous friends insisted upon aiding. We finally got the porter to take our telegram thrust under the door, and upon reading it he cautiously opened sufficient for us to squeeze through, having some trouble in keeping out our officious friends, who said we should kill the damned nigger for keeping gentlemen waiting. The door closed locked, to the intense disgust of our bodyguard, who vented their disappointment in bad words, banging knocks, and calls for several moments, when they retired with oaths not agreeable to hear.

I asked Tucker before leaving if he thought there would be any danger of an attack on the car. He said, "No; if there is any, shoot to kill, and we'll be up there on the run." And as he left, he repeated in the hearing of some of our body-guard, "Have a good night's rest, and if there is any trouble, fire a shot, and we '1l be up there quick."

We got along very comfortably until about ten o'clock, when our porter, who was a pretty well frightened fellow, and kept an attentive ear, informed us that a squad of men was coming up the track toward us. Sure enough, we saw them by peeping under the curtain at the door and immediately extinguished the few lights we had burning. The squad soon arrived, and for a while we heard them conversing at the car end, followed by a knock at the door, to which we paid no attention.

Several more vigorous knocks followed, with a banging sufficient to have awakened us from sleep, if we had been so engaged, and a rough voice notified us that an important telegram had been received. 
Divided upon each side of the end of the car, without making any response, we sat calmly with our repeating rifles in hand, fully prepared for any emergency which might occur, and determined to fire upon any intruders who might come in upon a forcible entry.

The united strength of several was evidently exerted in pressure upon the door, but without avail. Upon this being repeated, with violent kicking, Captain Slawson called out asking what the matter was, and was answered that an order had been received to get into the car. The Captain called out in a loud voice that no one could come in until morning, and if any forcible entrance was made, there would be an immediate killing.

Loose railroad ties were strewn about in the vicinity, and it occurred to us that one of these might be employed as a battering-ram to stave in the door. The Captain heard a mention of this from the outside, and called out in a still louder voice that if they broke in the door they would surely be killed, for we were fully armed in readiness. This settled the affair, and our callers retired after some further talk among themselves, well aware that results too serious for them would occur from any further advances. Toward morning we were awakened by our porter, who gave us word that some mysterious actions were going on beneath our car, and feared we were going to be blown up. We aroused quickly in response, and surely there were curious proceedings going on below. A slight investigation, however, put us at ease, as we found the cause of tnis noise proceeded from coyotes disputing for bones and offal thrown out by the porter. 
We heard a number of pistol shots during the night proceeding from the tented town, which we had no curiosity to investigate, but found in the morning that one man had been killed and several wounded-which accounted for the shots-resulting from a misunderstanding between some gentlemen of the town. There was no officer of the law at the settlement, but one Jack Smith claimed to be a sheriff, and exercised his authority that night with several assistants in holding up and going through a car-load of second-class passengers, that had arrived in the evening from California and was held over on the track for proceeding north the following day.

This fraudulently assumed sheriff, in the middle of the night, with half a dozen drunken assistants, stood up and robbed every one of the passengers on this car, assaulting and knocking down several of the victims who stopped to protest, or were too slow in handing over. In fact, no official agent of the law existed at the settlement, where every one was dependent upon himself or his friends.

The conditions at Deming, New Mexico, mentioned, reminded me of that which existed at Cheyenne in Wyoming Territory in the winter of $\mathrm{I}^{86} \mathrm{7}$, during the building of the Union Pacific railroad on its way to Utah to connect with the Central Pacific railroad from California. The "hell on wheels" camped here had signalized itself in a particularly atrocious manner at Julesburgh while on its way accompanying the railroad, and had for some weeks made a rest at 'the then moderate settlement of Cheyenne, where its force was largely 


\section{A Sportsman}

augmented by numerous ruffians from the surrounding region, among whom were many bushwhackers from Missouri, relics of the Civil War who had been scattered and driven west by the successful Union army, and who largely infested Colorado and Montana, where many were shot or strung up for their misdeeds. The night I came into Cheyenne at the terminus of the railroad, to remain over night and take a conveyance for Denver the following morning, something over a hundred miles distant, a most unusual affair occurred. A crisis had arrived. The "Hellers" had become so aggressive and arrogant, that a secret action had been determined upon by the peaceful and law-abiding residents of the town, to get rid of the turbulent element, which had become so powerful as to seriously threaten their safety.

Boasts had been made by the Hellers that they proposed to run the town, and if they were interfered with they would burn it up. A fire among the then existing rows of wooden buildings, with the prevailing high winds, was a subject to consider seriously. From a conflagration the Hellers were comparatively safe, as their array of tents, booths and vehicles were on one side of the town, before which they paraded in force well armed every day. The plan of the townsmen was well carried out that night, when a hundred men with repeating rifles at midnight appeared in front of "Hell Town," calling for the surrender of the most prominent Hellers who had boasted of their ability to regulate and burn the town if they chose.

A few defiantly stepped out from the tents in response, who were instantly shot down in their tracks. Ample notice had been given for the Hellers to 
remove, which they had paid no attention to. A volley of bullets was fired through the tops of the tents and sleeping wagons, from which all of the occupants hastily retired by the rear to the bushes beyond, and although a number of shots were fired in the retreat at the vigilants, none were hit. The town had been prepared and was on guard, and three or four of the Hellers found out in the streets were shot down. I slept so soundly that I did not hear the shots, but in the morning found the little town in agitation. But order was restored, and at an early hour the Hellers removed their effects several miles beyond the town on the line of the building railroad.

Committees of order and protection were formed, and proper guards were established. All arriving in town were disarmed, and had their weapons returned to them upon departure. The Hellers, well known, gave the town a wide berth. When I returned a few weeks afterward to take the cars for the East, I found the town largely increased and in good order. The "hell on wheels" had gone far on westward. I was shown an adjacent graveyard devoted to the burial of roughs, where I was informed over a score of bodies rested, without one occupant who had died a natural death.

In the forenoon, about ten o'clock, our conveyance arrived-an open wagon with four horses-and we were glad to leave the interesting town of Deming, somewhat perhaps to the regret of sundry individuals who insisted upon aiding us in storing away our baggage. A detachment of troops from the Fort Bayard government station, forty miles 
distant, arrived at Deming that day to assist in preserving order, at the request of the railroad people.

In a few hours we arrived at the nearest settlement from Deming, twenty-five miles distant, at the celebrated Hot Spring, owned by one Hudson, who conducted a moderate hotel for the convenience of invalids and others. This spring was of a remarkable character, and of ancient origin, having been referred to by the earliest travellers in the region between two and three hundred years ago. It has formed a basin of fifty feet in width, and some fifteen feet in depth above the surrounding level, formed by the débris of overflowing water during past centuries. The water was clear and greenish and bubbled up plentifully from the bottom of the basin. Its heat was almost up to a boiling temperature when it escapes from the bottom, and about the banks of the pool will pretty"well cook eggs in twelve or fifteen minutes. The water in the banks being higher than the surrounding land is conveyed in a ditch for irrigating a spacious garden, where vegetables, flowers, and vines are grown, as well as fruit and ornamental trees; and, although the water is not pure, is sufficiently free from impurities to answer for drinking, and is accounted by some to have favorable medicinal qualities, for which the spring is sought.

It seems to be a universal habit with humanity, when discovering any springs which are off the line of purity, to ascribe curative qualities to them, and no doubt many are highly beneficial. Those of Saratoga, the Sulphur Springs of Virginia, the Hot Springs of Arkansas, those of Carlsbad, Vichy, and other localities are noted in this respect. Beneath 
the city of Pueblo, Colorado, one of sixty thousand inhabitants, there is a large area of miles in extent where warm mineral waters of various quantities can be reached in from six hundred to twelve hundred feet below the surface, which have artesian pressure sufficient to convey the water up a hundred feet above the ground, and flow thousands of barrels a day.

Besides the Hudson spring there are many others of a similar but minor character on the plains within twenty or thirty miles of the Hudson. The flow from the latter is of such quantity as to make a moderate-sized stream, which runs off for a considerable distance before being soaked up by the dry soil.

While on the subject of springs, I will mention that New Mexico, a somewhat dry region during months of dry weather, abounds in many noted mineral springs of large volume. One I saw, the Berrendo, which broke out on a level plain, with a stream as large as a moderately sized man's body, which made a pool sufficient at all seasons to supply ten thousand cattle. At another place, where a large well was sunk twenty feet, it could not be proceeded with by further sinking, as water of fine quality flowed along at the bottom in a steady stream.

The Membres stream in the mountains fifty miles west from Deming, to which we were proceeding and where we made headquarters-camping there for a few weeks, and where we found fairly good trout fishing-disappears in the ground thirty miles from Deming, but, having a flow beneath the surface, supplies the town with a bountiful supply of good water, reached from twenty to forty feet below the surface. This flow of water is drawn plentifully 


\section{A Sportsman}

upon in the dry season by a large number of pumping wind-mills.

After a rest of an hour or two at Hudson we drove on for the Membres Mountains, twenty-five miles further on, reaching there about dusk, and prepared a rough camp for the night, building a better one the following day. We had a terrible scare on the way. The subject of Apache Indians was one of more or less conversation. We were aware that they had lately gone off the government reservation some sixty miles from our neighborhood, but no reports had been given of their being anywhere near our vicinity, and the United States troops from Fort Bayard, near our route, had gone out in force after them.

We had arrived in the foot-hills of the mountains, and it was mentioned that it would not be a very pleasant place to be met by Indians, for the road was narrow, and the neighboring hills, covered with pine growth, would afford fine opportunities for being waylaid. Looking well ahead, we were astounded to see two Indians with guns emerge from a ravine into the road, and walk along, followed shortly by several others likewise armed. It was a bad place for a scrimmage, as the road was too narrow to turn about in. We all leaped out with our repeating rifles, directing our driver to turn in and tie his horses in the brush by the road, while we separated on each side, prepared to make as vigorous a stand as possible for life, as there could be no surrender to savages so notorious for their cruelties and torturing as the Apaches. Behind trees and rocks we scudded with alacrity.

The Indians apparently had not observed us, as 
they were some way ahead. Singular, we thought, that these keen-eyed savages had not seen us. As we regarded them in the distance we were wonderfully pleased to see a white man on horseback emerge from the roadside and join them, and that he was in the uniform of our government, and we instantly conjectured that he was in charge of a party of Indian scouts, which proved to be the case. Our heart beatings began to subside, and we regained our seats in the wagon and drove on among them. They were a most villainous-looking troop, and paid no more attention to us than if we had not addressed them in the usual "How," "How." This sullen, cruellooking band shortly after broke away and joined the Apaches from the reservation on the war-path, and committed many forays and murders among the scattered settlements of the southwestern parts of the Territory. These Indians were finally gathered in by the United States troops, after many long and wearisome followings directed by General Miles.

Our camping place was in the Membres Valley, near the stream, where a few settlements of cattlemen and small farmers were, and a few miles above, the somewhat deserted mining town of Georgetown. We found deer plentiful in the neighboring mountains, which supplied us with meat, and from the streams obtained sufficient trout for our wants. Quail were plentiful, and an occasional wild turkey graced our table. A considerable Indian scare was on, which deterred us from going on to the White Mountains, and the Black range, from forty to fifty miles west, from which we had glowing accounts of game by those familiar with the regions. 
We had some apprehensions of danger from the proximity of desperate white men, cattle thieves who were having conflicts about us in the valley with the cattle-men, and they seemed in large force. This induced us to remove our camp west some ten miles to the Santa Rita Valley, where there were a number of deserted adobe buildings, besides a partly ruined fort built a century before by Spanish miners, where cannons were originally mounted to defend the workmen employed in the copper mines. These mines were very rich, containing much native copper, and were extensively worked in the eighteenth century, before any others on the continent now occupied by the United States, and for many years supplied old Mexico with its copper coinage. The copper from these mines was transported on mule's backs more than 500 miles to the City of Mexico. Copper at that time was high in price, ruling from fifty to sixty cents a pound, now considered high at fifteen cents. From I837 to 1862 these mines ceased to be worked, owing to the unsettled condition of a region where the Apache Indians held the country in tribute.

In 1863 the Confederate forces, being in want of cannon, invaded the region and had the mines worked for copper to the extent of over a hundred tons, which was transported across the country to Texas ports. After the war, until the time of my visit, the mines remained unworked until I became interested in them, and they have been worked continually since. These mines diverted me from the purpose I had of writing a history of New Mexico, as I did of Colorado in 1865 . 
We found the valley of considerable extent, surrounded by high hills, and a most pleasant place, having fine grazing for our horses, and good springs of water. Upon the summit of a high mountain rising east from the valley was an immense monolith of granite, having the form of a kneeling nun, visible for many miles from all directions, a prominent landmark visible for more than twenty miles. At one place, by the small stream which meandered through the valley, was an old peach orchard planted more than a century before, where the trees, dying of old age, had renewed themselves with new sprouts as the old trees fell away, and were now bearing fruit, though of an ordinary kind. We found very good sport about this valley, as deer were plentiful in the surrounding hills.

When we returned to Deming-heretofore mentioned-we found a great change had occurred. A large general depot was being built for the two roads. Many houses were going up, and order was pretty well sustained, although a good many rustlers were about. Tucker had been made sheriff, and had signalized his promotion by shooting down a number of turbulent characters. When committing one of these acts, an immediate hearing occurred before the local court, from which he received a speedy acquittal. When I came down to Deming some months afterward he had on the day of my arrival shot down a desperate character for whom a warrant was out, who had shot a cattle-man in the vicinity in a most unprovoked manner.

Tucker had killed a partner of this man, for whom a warrant was out, who was slow about throwing 
up his hands in an arrest, and this last victim had openly threatened the life of Tucker in retaliation. He came in on the day of his death while heavily under the influence of liquor for the purpose of carrying out his threat. Of this, Tucker was well advised. The man came in at the station on horseback, thoroughly armed, with his repeating rifle in hand, inquiring for Tucker. He rode up on the hotel platform and through an archway constructed in the hotel for foot-passengers to cross the tracks on each side. Meeting in this passageway one of the hotel employés, who held up his hands to warn him from passing, he knocked him down by a blow on the head from his gun, and passed through, dismounting on the other side, and after tying his horse proceeded to the restaurant in the hotel, where he seated himself with his rifle placed on the table in front of him, and called for some food. He seemed unable to eat anything, either from excitement, or the condition of his stomach.

Tucker was apprised of the situation and on the alert. The man shortly rose from the table, and with rifle in hand made his way out to regain his horse. As he came out from the passageway, Tucker made his appearance from the hotel side, where he had been waiting, and promptly ordered hands up. Although the desperado was looking into the two barrels of a shotgun loaded with buckshot, he attempted to raise his own gun in defence, but before he could raise it he fell, mortally wounded from the discharge of Tucker's gun, and the work of death was over. Tucker's shotgun, which he habitually carried when on the lookout for a close encounter, 
had its barrels sawed off within six inches of the stock, and could be well stowed away beneath his coat, and this he kept loaded with buckshot.

The body was lying in the railroad baggage-room, where it was a star attraction of the day. An inquest had been held, and a court hearing, from which Tucker had been immediately acquitted, as acting in self-defence in the execution of his duty. The region was less another desperate ruffian, and I think the notches on Tucker's gun were well up to a dozen.

Tucker was not left unmolested by the rough element, whose ranks he had depleted, and received several close calls from friends of the men he had put away. He told me that, however cautious he might be, he feared they would some day get the drop on him, and soon after this conversation, having one evening been shot at and slightly wounded, he pulled out from Deming for Ohio, his native State. $\mathrm{He}$ gave me what he considered valuable advice to be followed in close encounters when armed with his favorite weapon, a double-barrelled gun, sawed off short and loaded with buckshot - to shoot always for the stomach, for, if it did not immediately kill, it incapacitated the recipient from making any further resistance, owing to the deathly sickness which followed. I have never had an opportunity yet of testing the system.

Within four years after the advent of the railroad, Tucker had a list of seventy-odd names of bad men who he said had been disposed of by sudden and violent deaths in Grant County, in which Deming was situated.

I proceeded from Deming with Captain Slawson 


\section{A Sportsman}

and his assistant to Santa Fé, the capital of the Territory, which I made headquarters for some time, and frequently visited it during my trips to New Mexico, at one time staying there while Gen. Lew Wallace was governor of the Territory. I formed a very pleasant friendship with him, and we planned several excursions to take together in distant and unexplored points of the Territory for adventure and new discovery, to be accompanied by a detachment of soldiers, but which were never realized. At that time he was engaged in writing his celebrated work Ben Hur and he would often read over to me portions he had written, which I much admired, little anticipating, however, the great attention this book would receive when published, as it has been more extensively circulated and read than any other of late days. We often dined and had pleasant smokes together.

The Santa Fé railroad, which was hurriedly built through the Territory and from Deming to Arizona, met with more than the usual mishaps of newly built roads, and I waited one time for two weeks in Santa Fé, during the rainy season, for the road to be put in order from the washouts which occurred on the line north going to Colorado, and after leaving Santa Fé was a week in getting on to Colorado Springs, over a distance covered in usual time in a day. And one time, near Las Vegas, when we had halted the train, after going over a shaky place, the track and road-bed washed away behind us. The engine, cutting away from us, went on to investigate the conditions ahead, could not return, as the track broke away between us, and our train was thus left isolated 
for a day and a half. Altogether our train waited for the repair of over twenty breaks, on our way to Colorado.

The selection of route by this railroad was an unfortunate one, which has cost the company many millions and will continue to be costly in the future during seasons of flood, until a radical change in route occurs.

While in Santa Fé upon my first return from Deming, a friend of mine from New York, Mr. Ballou, arrived there, accompanied by General U. S. Grant, for the purpose of visiting a somewhat famous copper mining district, forty miles southwest in the Sandia Mountains, known as the Cañon del Agua. I was invited to accompany them, which I did. I had previously arranged with Captain Slawson, a mining expert in my employ, and his assistant to meet me at the Mexican town of Bernalillo on the Rio Grande beyond the district to which Mr. Ballou and General Grant were going. So this district was on my route, and I had several days to spare. We made the journey comfortably in a day with a government ambulance wagon, drawn by four mules, furnished from the military station at Santa Fé to the General.

We made our residence at the mines in the house of the mining superintendent, where accommodations had been prepared for us. I remained here for three days. General Grant having been President of the United States for two terms, and having rendered distinguished service to his country, was in consequence a most important man, and had been sought for by some parties interested in the mining property we were visiting, to take the presidency of a com- 
pany, which had been organized upon it. The pecuniary condition of the retired President and General was not an independent one, and it is reasonable to suppose that he had a desire to improve it, and many opportunities had been presented to him by parties engaged in various enterprises to advance his fortune, and likewise benefit the proposers in the advantages to be gained from his prestige.

In this instance, it was expected that he would take the presidency of the company which had been formed, with a salary equal to that he had received when President of the United States, of $\$ 25,000$ per annum. I am informed that he actually did take the presidency of the company, which he relinquished after one day's holding, and the company had an adverse result. During the two days after our arrival we made excursions on horseback over the property and its surroundings, and the General expressed himself as highly pleased with the result, and expressed the belief that the property presented a field of profitable exploitation for thousands of men for many years. This did not correspond with my own impression, which in my situation I had no occasion to express.

I had an opportunity of observing General Grant during these three or four days, and was struck with his simplicity and reserved strength. He was pleasant and unreserved. His knowledge of the country in its geographical features was remarkable, as he was entirely correct, somewhat to the surprise of his hearers, in his estimates of distances from point to point, accounted for by his good memory of information acquired in his early days when stationed in New 
Mexico as a lieutenant in the United States service. As a tactician he was eminent, possessing that faculty characteristic of all great generals, from ancient times down to modern, which in General Grant's instance, coupled with military training and indomitable courage and persistence, gained for him the success he deserved. Beyond these traits so prominent, and of such incalculable value for the success of the Union armies, I failed to observe in him any conspicuous features of comprehensive greatness. The great bard tells us some are born to greatness, others achieve it, and others have it thrust upon them. Many live and die in obscurity, lacking the opportunity to display their particular merits. But the opportunities occurred for General Grant, Cromwell, Cortez, Lincoln, and dozens of others whose names are familiar from the pages of history. There are but few, however, who have been great in all senses, of whom our Washington may be accounted one. A peculiarity of General Grant's most noticeable was his habit of incessant smoking. He seemed never without his friendly cigar. When he came from his chamber in the morning, it was with a lit cigar, and during the day it was only laid aside at meals, and accompanied him to his sleeping quarters.

Going on from the Cañon del Agua, I reached Bernalillo in a day's drive, finding Captain Slawson and assistant, and put up with Mr. Bebo, a Hebrew storekeeper established there. This Bebo was a goodnatured, pleasant man, who had with his family carried on a country store for several years, who gave us comfortable quarters. No hotel was in the place, and only a few houses were about, and these were of adobe and occupied by Mexicans. 
Bebo had written Captain Slawson that he had a most extensive and valuable copper property in the Sandia Mountains, the proposed examination of which had brought us here. According to Bebo's account, it surpassed any known elsewhere. He had never personally seen it, although he had its complete control through an agent who had discovered it, and whom he had supplied with moderate means to keep it in hand. It could be reached in a few hours' travel from the town, and its existence, for various reasons, had been kept a profound secret, which was now to be divulged to me, a possible purchaser, in a most confidential manner. His man was to arrive from the mountains that afternoon, and the time had come for him to arrive. Sure enough, he came. A sorrylooking mule of stunted growth, mounted by a cavalier of ample form but dilapidated in general appearance, held up at the store door. His unshaved face, blotched with red splashes, and watery eyes, partly hidden by his flapping sombrero, were not attractive.

He sat over a pair of well-worn saddle-bags, and about his waist was suspended a brace of revolvers. It was Jack Williams, the possessor of a burning secret about to be revealed.

"Come in, Jack," said Bebo.

"Yes, you bet I will, and I am half dead for a drink of whisky," answered Jack.

"Well, come in and get one-and take off your belt," said Bebo; remarking to me in an undertone, as he passed by, "I have to do this, for Jack sometimes gets a little high when he comes in and I have to put away his pistols."

This was comforting, and Jack proceeded to the 
rear of the store and rapidly emptied a medium-sized tumblerful of reddish fluid. $\mathrm{He}$ returned toward the front of the store, smacking his lips, and saying he felt "all right now."

We stowed away for the night, and in the morning, Jack, mounted on a mustang of Bebo's, and I, similarly mounted, left for the great mine, which no one but myself could be permitted to see. It was a drizzling, wet morning, and I went on with Jack, who was laboring under the influence of an evening's indulgence in red-eye, to the hills, while Slawson and his assistant took the trail for Jericho, the name of a settlement where Jack lived, and where we were to pass the night. Jack was very groggy, and, being supplied with a fresh bottle in his saddle-bags, took frequent libations to clear his sight, though he mistook his directions several times and I began to doubt if he would be able to find his treasure. The sprinkle had turned into rain, and I wished I was well away from the prospective Golconda, which was getting to be a mixed feature. Over hills and valleys we crossed and criss-crossed without being able to find it, and finally I became a good deal alarmed, especially when Jack seemed to be approaching a maudlin condition.

The mine was simply a myth and utterly worthless. It was certainly not an occasion for me to express a disappointment, or my opinion of the mine, and of Jack's character, which now stood clearly revealed. I felt bound to conceal my disgust, and, after again pledging myself to the utmost secrecy, persuaded him to pilot the way to Jericho, where we arrived after dark. This Jericho was a small Mexican settlement, composed of a few adobe houses, 
and had lately had a small gathering of miners attracted by alleged discoveries of gold mines in the vicinity, which had not proved of much value.

Jack had offered the hospitality of his adobe, which I found was a miserable tumble-down place, leaky and unfurnished and hardly fit for a stable. I found Slawson had fallen in with an old mining man whom he had known in former years in Montana, and had gone up with his assistant across the little creek which ran through the settlement, to stop with him, and had arranged for me to stop there also. Jack was a good deal put out at this, as he was not on good terms with Brown the miner, who he claimed was inhabiting his adobe without paying any rent, and said he would have his scalp before he got through with him. But Brown cared little for this, being a resolute man, and said Jack did not own the house, as it belonged to a Mexican who received five dollars a month for its rental. It looked cheerful to me when I reached it, where a blazing fireplace was giving out warmth, and the odor of fried bacon from the rear room made the hearty welcome I received still more agreeable. The adobe building I will describe, as it was the scene of a rather exciting episode that evening.

It was composed of two rooms; the front living one was about twenty feet square, with a back one of ten by fourteen used as a kitchen, containing an earthen cooking range, and a table, with two or three boxes for seats. The front room had only a plain table, two chairs and a few boxes for seats, no bed, but a few bear and deer skins on the floor which answered for sleeping upon, a few blankets, and some small articles, with some wooden hooks on the walls 
holding clothing, with two guns and a brace of revolvess.

After a hearty meal of fried bacon, potatoes, bread, and tea we were seated on the boxes and chairs, while Brown was seated on a bear skin on the floor, opposite the fire. $\mathrm{He}$ and Slawson were reviewing their experiences in Montana, and the river-bank sluicing they had been engaged in. The open door was darkened by the entrance of Jack Williams, clad in an old blue army overcoat, who came in from the rain and seated himself on a vacant box near the fire. He had given no knock at the door, and unbidden took his seat without saying a word. Brown and Slawson after a moment's silence continued their conversation about times in Montana. Otherwise the silence would have been more awkward. After a few moments Jack spoke up to Brown, telling him he wanted him to vacate the premises, as they belonged to him. Brown, quietly seated, responded that he hired the house of a Mexican, paying his rent of five dollars a month, and that he proposed to remain, and doubted very much if Jack owned the property. Jack then with much profanity accused Brown of taking away his friends (meaning ourselves) who came out to stop with him. This and some more, when Jack became so abusive that Brown, still seated, ordered him out. Upon this Jack rose in a threatening attitude, addressing Brown with a string of vile names. At this Brown rose from his seat, and seizing Jack by the back of the neck pitched him with much force out of the door into the rain. It was too dark outside to see where Jack fell, but he quickly recovered himself, and pulling his pistol fired two shots at Brown, who still stood in the open doorway. Both shots 
missed, taking effect in the adobe wall close to the doorway, as we observed in the morning.

Brown at these shots rapidly fell back and seizing one of the revolvers hanging by the fireplace, emptied the barrels of his pistol from the doorway in the supposed direction of Jack. All was then still, and Brown expressed his belief that he had surely plunked Jack; but no search was made outside, nor was the door closed, and Brown shortly resumed his seat on the bear skin, and his conversation with Slawson about Montana matters, picking up the subject where they left off.

I confess I did not feel at ease, and took pains to seat myself out of range from the door and the two windows, one being in front and the other on the side toward Jack's house.

A few moments afterward the doorway was filled by another caller. It was a man named Graham (between whom and Jack existed a grudge), who hastily inquired the cause of the shooting he had heard. This Brown explained, relating the particulars. "Good God," said Graham, "then it was Williams who passed me as I was coming up here. Oh, if I had only known it was he, I could have shot him easily." Out he rushed, thinking he might overtake him. But we heard no further shots, and he evidently failed to overtake the valiant Jack, nor did Graham return.

The morning opened clear and bright, and we mounted our horses and returned to Bernalillo. As we passed Jack's miserable adobe he came out to meet us. Just then came Graham along well mounted on a gray mustang. He held up, and finding where we were going said he would accompany us. I looked for trouble, as both were armed with a brace of pistols 
usual with these cavaliers. I looked for immediate trouble, as Jack sneeringly remarked to Graham, chagrined to find he was going along with us: "Well! You can take me in now if you want to," but the latter rode ahead without making any reply.

I told Jack I would see Bebo, and we passed on, leaving him cursing as we departed. I told Bebo I could not do anything in the mine, without entering into any further explanation, and we rode on to the town of Algodones, further up the Rio Grande. From this town we rode on to a valley a few miles off the road in the hills to view the ruins of a former Pueblo settlement, now entirely deserted, and which had been for a long time. We were attracted to the place by the accounts we had received of the wood petrifications there. We found a large number of petrified trees, evidently palms, remnants of ages before, when the palms evidently grew in profusion, while now only stunted pines existed.

The evidence was conclusive that in some early period the climate of this region was semitropical, and that this condition existed not only here, but for hundreds of miles further north; and at the present day broken fragments of palm-tree petrifications can be gathered below the foot-hill regions on the plains beyond the present city of Denver, in Colorado, at places quite plentiful.

We found in the valley we visited, immense palmtree petrifications, whole trunks of trees several feet in diameter, and scattered in profusion over a larger area, fragments of Indian pottery, showing that at one time the region must have been largely inhabited by a lost race, of which no history exists. Great 


\section{A Sportsman}

climatic changes have occurred in this region and north beyond.

At one time the Atlantic Ocean extended to the base of the Rocky Mountains, as clearly indicated by the immense deposits of sea-shells and petrified marine animals now found at the base of the mountains.

The predecessors of the whales, black-fish, grampus, porpoises, and other warm-blooded animals of the sea, were here once in active life in prehistoric times, of which unmistakable evidence is found. At the time of the semitropical climate, when all the land from the present Atlantic Coast to the Rocky Mountains excepting a few hundred feet of Mount Washington in New Hampshire was submerged, and probably long before man had appeared in any form similar to that of the present, the saurian family existed in great variety, of which the ichthyosaurian remains found from California to Wyoming indicate the immense profusion of this class in variety.

The remains of this immense animal, showing a frame as large as that of our modern whale, are comparatively plentiful in Colorado and Wyoming, from which I have seen and secured petrified fragmentary specimens. These immense saurians were more or less amphibious, and may clearly be designated to have been the whales of the Triassic and Jurassic periods, showing in their anatomy the bones of the fingers, feet and arms, and joints as exhibited to-day in the flippers of the whale. These indicate an adaptability for land life, once experienced in the history of this largest animal of creation, representative of myriads of aquatic reptiles dwelling upon land.

The recent discoveries in Italy, California, Nevada, 
and Wyoming have resulted in the generalizing of diversified groups of aquatic mammals of earlier types in the mixosaurus and shastasaurus class of reptiles, distinctive links anterior to the life of the mammoth fossilized saurian remains found in Colorado, to be yet further detailed, from which the evolution of the whale and kindred genera is readily traced, as distinctively as that of the horse of the present day from its five-toed ancestral type of inferior size.

Curiously interesting is the history of evolution, yet but partially explained, but sufficiently to indicate a great future advance, though probably never to be fully illustrated.

$A_{\text {NoTHER to the Navajo Indian government reservation of }}$ $3,000,000$ acres, situated in the northwestern part of New Mexico, extending into Arizona. This tribe, formerly a numerous and powerful one, is in late years reduced to a few thousand. Comparatively peaceful by the restrictions of government, they, however, break out occasionally in moderate ravages from the restless character of the young braves, but are held in good restraint, and follow a halfcivilized life, having horses, sheep, goats, and other domestic animals, and cultivate small tracts of land in corn, beans, and other vegetables.

On their native looms they manufacture a good many blankets of various colors, known as the Navajo, which have an extensive sale. Many of these are of fine texture, and often sell as high as $\$$ Ioo or more. They are 


\section{A Sportsman}

warm and durable, and are often in gay colors from native dyes, and are plentifully met with in New Mexico.

These Indians are governed by their native chiefs by rude laws of their own, and some are quite industrious, though in this respect behind the Pueblo tribes, of which there are many, who are village dwellers and have always been peaceful with the whites, excepting in the general uprising which drove out and exterminated all the Spaniards, their cruel oppressors, in I680.

A marked degree of difference is also observed between the Navajos and many of the other Indian tribes upon reservations, located in the vicinity of white settlements, where the effect of example is distinctly evident in the respectable appearance of the Indians.

The Navajos are still fierce-looking, and cling to their old costume of buckskin leggings and moccasins, enlivened by the gay-colored government blankets, which are much less durable and expensive than their own. Their fondness for ochre pigments is as strong as ever, and is shown on their faces generally, and painting up is a feature of observance upon the eve of any visit from the reservation, or in fact any event out of the ordinary line.

Could the history of this once warlike tribe be given, it would be one of great interest, and give much light upon the early history of the vast region once occupied as the scene of their plundering forays and murderous descents upon the peaceful Pueblos and Mexican settlers, when whole families and settlements were exterminated. With the many Apaches occupying the regions south, and with whom the Navajos were in perpetual conflict, but were mutual in plundering and murdering all they could reach 
over a large area held in terrorism, it is likely that many dark pages of history could have been written of Indian savagery, now forgotten in oblivion, and only attested by the ruins of large community buildings, the stone watch-towers upon heights, and the deserted habitations of the cliff-dwellers.

After the declaration of peace with Mexico in I 847 from which the United States acquired its immense western domain, the ravages of the Navajos and Apaches were frequent subjects of attention by Congress, and many detachments of troops were required before the Indians could be made to occupy the reservations determined for them. Despite all efforts of the government, it was many years after the Navajos were settled before the various tribes of Apaches were gathered in.

In making the excursion to the Navajo country, I was accompanied from Santa Fé by my wife and my cousin, Mrs. Wood, also by Captain Slawson and his assistant, and one Meyers, who had induced the trip by representations of valuable copper mines near the Indian reservation, which he claimed to own. There are a great many kinds of people in the world, a description of whose varying peculiarities would fill many volumes.

I have described previously the character of Jack Williams, who lived upon the credulity of Bebo. There are many prototypes of Williams, varying more or less according to attending situations, from Williams up to the plausible villains who palm off bogus gold bricks and mines without value.

There seems to be in mines a fascination to many, which creates a credulity and easy confidence not 


\section{A Sportsman}

allowed in the consideration of other business subjects. The large advantages gained by some in mining, exceptional cases of success, stimulate the feeling for gain beyond the exercise of sound reason. Mining interests therefore attract a class of adventurers more plentiful than connected with other interests. Many of these adventurers are ready to take advantage of the public in any manner and by any dishonesty they can bring to bear, while other adventurers, with a blind confidence arising from ill-regulated and inexperienced conditions, although sensible otherwise, will lead on men far superior to themselves in acuteness, and involve them in the following of an "ignis fatuus" phantom which leads to mire and loss. This class is perhaps more dangerous than the first. But the worst of all is the plausible rogue who has confidence in his ignorance.

This Meyers represented an entirely different type than that of Williams, being a man of education and some scholarly attainments, and the author of some interesting articles regarding mechanical and mining appliances, which had appeared in a prominent mining journal. Despite this he proved to be a man of impracticable ideas, deficient in good sense, fantastic in action, and hyperbolic in illustrations; arrogant to those we met on our route, untruthful, and in fact a complete knave whose questionable actions afterward gave him several experiences within prison walls. He, however, stood well in the simple community where he resided, excepting with the store-keepers, and posed as an eminent authority in scientific affairs, and having a comfortable and scholarly appearance sustained at first pretty well 
the good recommendation given of him from one of the substantial townsmen with that ready willingness so common in the extreme West.

Meyers claimed that he had acquired an immense tract of land known as the Nacimiento Grant in perfect title from the Spanish and Mexican governments, ratified in patent by the United States, which abounded in immense ledges of sandstone, impregnated by nodules and particles of pure copper, which would yield large profits if worked by modern methods. The presentation was attractive from a prima facie view, and to some extent as alluring as that which induced the adventurous Coronado in earlier days to traverse the same region in search for the golden cities of Cibola. The evidence in result was that the romancing Meyers had not a penny's interest in the grant, or any means for acquiring one, and the copper existing in the ledges was of such insignificant proportions as to prove unprofitable even if worked over by the complete manner followed in the Lake Superior regions, where less than one per cent. of native copper gives large profits. But the region was very extraordinary and interesting, where the geological features were unique in character. Once it had been the bed of an immense lake into which had flowed streams carrying trunks and branches of trees, principally palms. The water of the lake from some cause had been strongly impregnated with copper in solution, which saturated the logs more or less, and the wood became petrified completely, and the copper solidified in the wood in a metallic form in minute particles. Then a convulsion of nature occurred, a mighty upheaval of 
the bed of the lake, which with titanic force threw about the sandstone ledges in a confused manner. I saw some specimens which would be difficult to duplicate elsewhere, of strips of petrified palms carrying bright particles of native copper, and, more wonderful yet, small running veins in the wood of as bright, hard anthracite coal as could be found anywhere.

Our outfit consisted of a two-seated carryall with a pair of spirited horses from a town stable, driven by the proprietor, a Mr. Strong, to carry my wife and cousin and self, with the driver; in addition a common covered Bain wagon with a pair of horses, to carry Captain Slawson and his assistant James, with a tent and supplies. Mr. Meyers was to accompany us on horseback as we understood, and so started out from Santa Fé, but presently demurred when a few miles out, saying that he had expected we would have a place for him in the carriage, which we thought at the time was unusual for him to expect, since he was supposed to have more invited us upon the trip, to view his property for sale, than we had invited him. But as he found so much fault from horseback riding, to which he claimed he was unaccustomed, we gave him a place in the wagon, having his horse led behind. Presently he found the wagon, without springs, too severe, and we took him in the carryall, as my wife volunteered to take his place in the wagon. As I thought it over, it seemed so unreasonable for an apparently strong man to take the place of a woman in the carriage, I intimated rather strongly that he should return to the wagon. This he was compelled to do, but instead of taking the wagon he mounted his horse and went on 
ahead, as he said to arrange at the Mexican town of Pena Blanca, twenty-five miles further ahead, where we intended to pass the night, for our accommodations. That was the last we saw of him until the following morning. When we arrived there about dark we looked for him in vain, and put up in two or three of the ordinary adobe houses, there being no public house.

In the morning he appeared on horseback as we were about starting away on our journey, accounting for his non-appearance before by saying he had not been well, and had gone to the house of a Mexican friend for the night. We now commenced a journey over a waterless district of fifty miles after fording the Rio Grande, and it was necessary to take on a barrel of water to carry ourselves and our horses over, having a stock of hay and grain in the wagon with our other supplies.

We passed over this desert in two days, reaching the Rio Purco, a muddy stream, but where the country was more fertile, with reaches of pine timber and pleasant stopping places. The habitations were few and far between, and we found the camping out preferable to abiding in any of the few adobes we met with. The scenery was attractive in many respects, though away from the streams and valleys the faces of the mountains were barren beyond any hope of ever making fertile.

One prominent mountain height seemed ever conspicuous, that of Cabazon, or the Cabbage Head, which was the guide for the direction we were to pursue. This we finally passed, following up the Rio Purco, and reached the mesa of the Nacimiento in six days 


\section{A Sportsman}

after leaving Santa Fé. We were a great surprise and attraction at the few Mexican settlements we passed through, as no white woman had ever been seen there before, and the inhabitants, men and women, old and young, and the children would come about us as if we had been visitors from another planet. It amused us to tear out leaves from a few illustrated magazines we had and distribute them among the people, which were sought for with the greatest eagerness, and the fortunate possessor of one of these pages became immediately the centre of a delighted group. We met on several occasions small bands of Navajos, looking more savage than peaceful Indians should. They were accompanying small bands of sheep which they were driving out for disposal at Mexican towns. Mounted and dressed in their buckskin garb, with gay blankets and hideously painted faces, with red bandana handkerchiefs bound about their heads, they looked ferocious enough to pursue the wanton pastimes of their ancestors.

At a spring one day, where my cousin, Mrs. Wood, was temporarily lingering away from our party, she was much alarmed by the approach of a Navajo painted brave, who came on horseback at some speed, brandishing a quart bottle which he held by the neck in his hand. Espying her he stopped and addressed her in the mixed dialect of Spanish and Indian tongue, at which she was much alarmed, but relieved at the approach of Captain Slawson, who explained the object of the brave as being to have the loan of a drinking cup which Mrs. Wood had with her.

Intoxicants are forbidden by law from being 
furnished to Indians, but little attention is given in New Mexico to this, and the Navajos, though temperate in the main, have means of obtaining liquor when particularly desired, as indicated by several of their number whom we saw under its influence. Most Indians are gamblers, and the Navajos are particularly addicted to it, and skilful, and adepts at cheating. We saw the success of one of these warriors, at a Mexican village near Santa Fé, when on our return, where he obtained all the cash of a small sheep-owner and his flock also, of something over a hundred head, which he was driving home to the reservation.

We had some adventures in fording some of the small streams on our way. At one of these fords our carryall as well as our wagon stuck in the mud so effectually that we had to wait some hours for a pair of oxen to haul us out. We had an amusing incident with Meyers, the fourth day out, illustrating one of the peculiar features of his disposition and make-up. It had rained in the night, somewhat to our inconvenience, and commenced again in the morning as we were about to start on. As our cuisine department was not equipped with a cook we had first depended upon Hussey, the driver of our wagon team, who had recommended himself to us favorably in connection with his expressed opinion that he was high up in the line, and intended to open a restaurant in Santa Fé upon his return. We found his work so wretched in this particular that I took this department in hand myself, and delegated him to the dish-washing line, but his results in this were so unsatisfactory that my wife and cousin were com- 
pelled to take it on. Meyers had the quality of a great soldier and worker in the essential of a vigorous appetite, and exhibited a commendable promptness in appearance at meal times, and to use an expression of Hussey's "could bolt four days' rations at a single meal." His cultivated taste was evinced particularly in the selection of our delicacies, which were limited for the campaign. We had not called upon him for assistance in any particular, nor had he proffered any. As we were ending our breakfast it commenced to sprinkle, with an appearance of increase, and we made haste to finish up and take the shelter of our teams. As we were completing the dish-washing act, I asked Meyers if he would assist in packing away the washed tableware, and aid in stowing away the cases and baskets in the wagon which stood ready for departure. I could hardly believe my senses when he declined, and there was no time for discussion at the moment. At midday, when we rested for the noon meal and he stood about in readiness for his usual onset, I asked if I could be sure that he had declined to aid in loading up our wagon, at the commencement of the rain that morning; to which he answered, "Quite so," and that before coming to America he had solemnly vowed never to engage in any menial labor. I had pretty well digested the matter before asking, and quietly informed him that his vow was a most unfortunate one, as it would effectually debar him from any participation in our meal now preparing, or in any other during our excursion, as we were doing our own work, the cooking and the cleaning up, hand in hand in social union, each doing his share, and quite willing to do so in proper 
appreciation, but I certainly could not allow his further participation in benefits derived from our mutual exertions, which his claimed superiority of station must from that moment debar him from. He received my decision in silence, and mounted his horse for a neighboring settlement. I thought he would then probably desert us, but he came into camp at night as usual, and afterward caught up his meals as he could outside of our supplies, and accompanied us to the Narcimiento, leaving us there, and we saw no more of him.

HAVING had over forty years of annual experiences 1 about the Rangeley Lake waters in winter and summer, and having passed several months in many of my visits, I have observed some features about trout and animals which may be of interest to fishermen, and which may throw some light upon the lives of those fish, which are so gamy, beautiful and delectable.

I will simply give my experiences and opinions without any intention of entering into any controversy with other fishermen whose experience, perceptiveness, and conclusions may be different from or superior to my own.

In referring to the Rangeley Lakes I include that chain of larger lakes situated in Oxford County, Me., commencing with the Rangeley, the Mooseluckmeguntic, the two Richardsons, and the Umbagog, with the adjoining and connecting small lakes and ponds. The large lakes mentioned comprise a surface area of eighty square miles, and the principal tributary lakes and ponds, more than thirty in number, comprise an equal surface area, or a total of 160 square miles. 
The drainage area tributary to the system comprises over 3000 square miles, which is almost entirely forest. The average precipitation of rain, which includes that from melting snow, is estimated at 42 inches. The altitude above tide water varies from I 200 feet to I 600 feet.

The Rangeley waters are all well stocked with trout, excepting the Umbagog, the lower lake (partly in New Hampshire), which a dozen years ago was found to contain pickerel, and these have been disastrous to the trout, and in consequence have thinned out the greater proportion of the small fish, although some quite large ones are now occasionally caught. I have heard of several being caught weighing from eight to nine pounds. In winters, until the railroad was completed to Bemis lately, it was difficult to get at the principal lakes, excepting Rangeley Lake proper, which adjoins the small town of Rangeley, and there are no settlements or towns adjoining the big lake or the smaller lakes or the Richardsons, excepting the town of Andover, which is twelve miles from the head of the lower Richardson, and which is connected by a road so little used in the winter that I formerly had to get it broken out for my party, and have sometimes had to go to the expense of $\$ 40$ or $\$ 50$ to do so.

In one instance, a number of years ago, five feet of snow fell while I was at the lake, and drifted so badly that I had to snow-shoe my way out with a companion over the mountains, twenty-two miles (we being up the lake twelve miles), which required our almost constant exertions for seventeen hours, leaving at 6 A.M. and arriving out at Andover at II P.M. In one instance we were two days in getting over the road 
from Andover, twelve miles to the arm of the lake, although we had two stout teams, but had to shovel and tramp through heavy drifts of snow, and were compelled to camp over night on the road. Several other times I have been compelled to camp at the arm of the lake by having the ice break up after it had frozen, and in one instance I had to wait a week at the arm for the ice to form sufficiently strong to get over. In fact I have had quite a number of adventures in getting up to camp on the Upper Richardson Lake over the ice in the winter, and especially since the comparatively late law on deer shooting, which ends the season on December 15 .

To get the December shooting about the lakes is difficult, as one must get up the lake by boats, or on the ice.

From the middle of November the ice generally makes about the shores, making it difficult to get boats in or out, and very seldom does the ice hold after its first freezing over, although it may get an inch or two thick, and sometimes it breaks up when it is three inches thick from the sea made by a high wind on open places. The open places will grow larger, and sometimes will break up the entire lake surface; at other times it will open in three or four or more parts, while the parts left closed will accumulate ice to the thickness of seven or eight inches, and at such times one must haul a boat over the frozen portions and row through the open ones.

The lake generally freezes up from the Ioth to the I 5 th of December, wholly, or sufficiently so to pass teams over. Parts of the lake in the vicinity of springs or currents will continue weak at all times in the winter, and it is not very uncommon to break in with 
horses, though they are generally hauled out safely, owing to the firm ice which adjoins the soft parts. The weak parts are pretty well known however, and avoided.

While the cold in the winter, as indicated by the thermometer, would seem extreme, it is not particularly severe to those who come well prepared and have a comfortable camp, for the dryness of the atmosphere militates against the effect of the cold in a most favorable manner. That chilliness and bone-penetrating cold which one experiences even in moderate weather on our eastern or western seaboard, is little felt at the lakes in the winter; and, familiar as I am with many climes, I will say that I have suffered more from cold, which my memory vividly reminds me of, south of Washington and amid the orange-ripening localities of California, than I have in all my experiences in winter at the Rangeley Lakes.

Yet during my excursion here in the winter of 1890 and $189 \mathrm{I}$ the self-registering thermometer in front of camp indicated for thirteen consecutive mornings an average of 8 degrees below zero, the warmest, lowest marking being 26 degrees below, and the warmest morning being I 2 above. That was an extremely cold spell, as noted by the usually reliable oldest resident in the country, who had no remembrance of so cold a period in forty years.

One of our family trips made in 1895 , was particularly pleasant, and not far behind 1890 in cold; yet no day at the lake was too cold for the children of our party to be out snow-shoeing, skating, and tobogganing.

Our trip was not made for shooting or fishing, as we arrived on the last day of the open shooting, December 
$3 I$, and we were strict observers of the game laws. We came to enjoy the cold bracing weather, to enjoy the sports of winter, and to view the beautiful ice-bound lakes and the forest and mountains; to witness the dark and purple hues of the fringing woods, and of the distant ravines; to observe the countless minor features incidental to the season at the lakes, of which a recounting would be tiresome perhaps, but of constant note and attention to all lovers of the woods and waters. The woods and waters are always fascinating, be it winter or summer, the former equal to the latter-the woods in their dark green or with their coatings of white, the water delightful with its calm and changing surface, or clasped with mantles of ice or snow. This is the sanitarium for many invalids, while enervating warm climates are pernicious. Here will be found the enemy of insomnia, here the stimulator of appetite and the true pepsin of digestion, here the conqueror of ennui and care.

Our party of nine, four being children and two ladies, exclusive of guides and assistants, came in safely from Andover, Maine, on the last day of the year. We were held up two days at that town by the general blizzard, which coming from the west gave the New England coast a cold blocking storm. The weather during the two days at Andover was simply howling, the mercury holding obstinately below zero, and the air most of the time filled with cyclonic whirls of snow. But we were comfortable at French's Hotel. On the morning of the 3 Ist it was still and clear, with the thermometer I 8 degrees below zero, and it held below zero all day, closing at sundown at so below and opening the following morning at camp 22 below. 


\section{A Sportsman}

The trip of twenty-two miles through the woods and nine miles up the Richardson lakes was entirely comfortable and free from touches of King Frost. It was slow going, however, from the necessity of breaking out the road and testing the ice, consuming four hours, including thestop of an hour and a half midway for lunch and warming up at the foot of the lake.

During our stay of two weeks we had but few mornings when the lowest marking of the thermometer was above zero. On January 5 three of our party left to meet friends at Montreal. The marking of the thermometer was I4 degrees below zero at their time of leaving, ten o'clock, for Andover, and closing at night 8 degrees below, but the trip was made without any discomfort whatever. The night of January 4 was the coldest of any, there being a perfect gale of wind from the northwest all through the night, with the thermometer I 8 degrees below zero, but the morning opened still and clear, and comfortable enough.

A gale of wind with the thermometer nearly 20 degrees below zero constitutes unmistakably a blizzard, which would be fatal to human life unless somewhat protected from its fury. In our case, although the camp was openly exposed upon the lake shore to the full blast, we experienced no inconvenience. With double windows and large fireplaces in every room, filled to repletion with consuming birch and maple we were hardly conscious of the extreme cold outside, and passed the evening in witnessing the theatrical entertainment given by the children. To be sure, the cold gale was searching, and, despite the fires continued through the night, it found out the water 
pitchers in remote corners, and glazed them over with its imprint.

The night was a comfortable one, for a slight freezing in one part of a room with a glowing fire in another part cannot be otherwise than comfortable in a dry air, to a well clad and well nourished mortal. Still the contrast was striking between the blizzard of the night and the still air of 18 degrees below in the morning. It seemed hardly necessary to wrap up for snow-shoeing.

I would account a still clear cold of 60 or 70 degrees below zero to be far more comfortable than a gale of wind having a velocity of twenty miles an hour with the mercury at I 5 or 20 degrees below zero. The first could be endured very comfortably in an ordinarily well protected apartment before a glowing fire, but the latter has a searching power, which insinuates itself through the slightest crevices of the doors, windows, and floors, and of penetrating, when one is exposed to it, all the clothing one can put on. A moderate head wind at zero is far more biting than still cold at 30 degrees below. In fact no one but an Esquimau or the exceptional man can endure the facing of a gale at 20 degrees below zero, with any part of his face exposed, for more than a few minutes, for the white frosting will form on the skin almost immediately, and with double veiling the eyelids will soon glue together, and a glazing of ice will form over the mouth and nostrils. The face would freeze so quickly that one would hardly be aware of it, as it would be comparatively painless.

I was snow-shoeing in the afternoon before the blizzard came on.

The morning had opened 22 degrees above zero 


\section{A Sportsman}

not very cold, but began to drop steadily after ten o'clock. I had crossed the lake with my son Vincent, to enjoy our lunch by a fire built upon the opposite shore, perhaps two miles from camp. I observed that the sun had a peculiar cold aspect and that the air was filled with countless particles of snow, which although as minute as diamond dust flashed and scintillated in the sunlight, a sure indication of intense frost. The tiny flashing crystals came from the moisture in the air, for the sky was cloudless, although tinted with an ominous hue which indicated some change from the quiet of the previous few days. I deemed it prudent to retrace our steps to camp, for the winter's short day was drawing to a close. When half way across the lake we observed from the upper end approaching eddies of whirling snow, and before we reached the camp they were about us, the sun had disappeared and the whole sky had become obscured from our sight by the driving flurries. The blizzard which lasted through the entire night had commenced. The wind fortunately was at our backs, and with well hooded faces we experienced no inconvenience. The air was so clouded with snow about us that no lake shores were visible; and only from our old snow-shoe tracks, not entirely obliterated, could we find our way correctly.

It was four o'clock, about sundown, when we reached camp. The thermometer indicated ro degrees below zero. Before six o'clock the mercury fell to I 8 degrees below, where it remained all night, accompanied by howling bursts of wind which seemed bent on forcing in windows and doors. But the fury of the gale was lost upon us, and the morning opened quiet and serene, 
and seemed moderate in its still coolness of 18 degrees below.

A few days after this blizzard we learned that an unfortunate visitor at the big lake two miles above us (the Mooseluckmeguntic) had been caught out in it and very nearly lost his life. Alone and on foot he attempted the passage of eight miles from Haines Landing to the Upper Dam, and when overtaken by the whirling clouds of snow, which hid the shores, lost his bearings.

He could not face the gale and drifted with it until he reached the shore, a long way from his course. Here, after passing into the forest a bit, and getting some shelter, he succeeded in building a fire, which saved his life. His ears, hands, and feet were half frozen. In the morning he found he was near the closed camps of Capt. Barker at Bemis Stream, four miles out of his course. He was unable to proceed further, still being eight miles from the Upper Dam. He broke open one of the camps, where he found plenty of firewood, but nothing to eat, and remained two days without food. He then made his way to the Upper Dam, eight miles distant, where he arrived, though he fell senseless on the ice when within half a mile, but was observed and brought in and finally fully recovered, though left in a very bad condition-as from freezing the flesh sloughed off from his hands and feet, and all his fingerand toe-nails-yet he still visits the lake.

In Igoo I came to camp on Thanksgiving day from Bemis on the Great Lake, with my son Vincent and a friend.

It was eight miles from Bemis across the lake to the Upper Dam on our route, and two miles from there to 


\section{A Sportsman}

camp. The temperature was at zero, and the big lake was almost entirely frozen over with a thin ice. We had a fine time, with a stiff gale blowing in the direction we were going, with two boats breaking our way through it, doing so for nearly all the distance with heavy tree boughs from the boats, but found the ice, when within a mile of the dam too strong to break. At this we landed on the shore, and finished the last distance through three feet of unbroken snow, which was slow work. The lower lake was comparatively free from ice, which we finished with boat, arriving at camp soon after dark. Two weeks after our arrival we had a severe blizzard, the 9 th of December. On that morning the thermometer stood at 24 degrees above. I noted then that the barometer had fallen very low-lower than I have seen it for some years, excepting that year, September I 3 th, when the remnant of the Texas hurricane which destroyed Galveston reached the lake, lashing the water into great fury. Then the thermometer sank rapidly in a severe gale from the northwest, with flying clouds of snow, and by six o'clock in the evening was down to ro degrees below zero, and finally reached I7 degrees below, when the gale from the northwest increased with great force, and continued throughout the whole night. On the morning of the Ioth the thermometer exhibited 13 degrees below zero, with the gale moderated but still strong. By ten o'clock the thermometer was up to 9 degrees below, but remained below zero all day, but we put in half an hour skating on the new glare ice, which was quite sufficient for us. We secured three deer upon this excursion.

The trout of the Rangeley waters, designated as 
the Salvelinus fontinalis, are the true speckled, carmine-spotted, and of the highest type in game qualities and flavor of any which inhabit any waters, excepting those of a kindred character, and it is very difficult to find any other waters of equally favorable characteristics. I say without prejudice, having taken trout from some forty different localities in the State of Maine and in many other States in the Union, as well as in foreign countries, that the Rangeley Lakes trout altogether are of finer form, color, and flavor than those of any other waters I know of, while for average size they surpass any of their class. Take them at any month of the year, they are fat and deliciously flavored. There will not be one in a hundred which from age or disease is out of condition for food, although I will except the spendthrift milter, in the late autumn; for, though arrayed in his most brilliant intensified suit of scarlet waistcoat with dark trimmings, mottled coat, spangled sides, and white and black leggings, he has a sinuousness and a lacking of flavor which should give him liberty and an opportunity for recuperation. I will not, however, except the full spawner, which, owing to high feed, remains in good condition, deteriorating somewhat at the termination of the spawning period, from which, however, a speedy recovery is made.

The opinion that pure water of crystal clearness is essential to the perfect existence of trout is not sustained by the condition at the Rangeley waters. Owing to the densely wooded country about, and the excessive precipitations of moisture, and the constant forest leaching which occurs, all the waters with a very few limited exceptions are somewhat opaque, 
having a yellowish tinge, which indicates the impregnating effect of the abundant adjoining plant life. This vegetable stain has its sequence in the furnishing of the first source of trout existence by the apparent spontaneous prodigality of infusorial life. This is clearly evident without microscopic aid, and throughout the waters, in a greater or less degree, is plainly evident to the unassisted eye. This is the primary constituent essential to young fish life. The young trout or salmon, when relieved of the umbilical sac, is of minute proportion, and is unable to live upon the surface ephemera or food of after life, and subsists wholly upon the infusoria, as do all the small fry generally designated as minnows, of which there are a dozen varieties in the Rangeley waters. It is also the principal food of the fresh-water smelts. The profusion of small fish in the lakes supplying the principal food of the trout and salmon accounts for their number and superiority, without which they would be lacking, so that in reality the primitive cause is the infusorial element. This element abounds in all ponds, lakes, rivers, and even ditches where decaying vegetable and animal matter exists, and in countless profusion. It is found in thermal springs, and rivulets flowing from snow-banks and glaciers, and in salt as well as fresh water. No form of life can be more universal and extensive, while of so minute a character in the sea, and in many fresh waters, as to require the strongest magnifying power to clearly observe. Even distilled water, upon exposure to the air, will exhibit the life. Freezing does not destroy it, nor will a deprivation of its watery element. It may be dried in the sun for many days, but its germ form when drifted with the dust to reviving 
waters will again take on active life. Ehrenberg, a celebrated German authority upon the subject, estimates the reproductive capacity of a single one to exceed $200,000,000$ in the space of a month. The variety of the infusoria is extensive, more than a hundred being classified.

The Poligastrica and Rotatoria, two prominent species of the infusoria, are white, pulpy substances, some of which are of pinhead size. Through the winter ice over a clear sandy bottom, with a thin blanket head cover, which by no means excludes the light, one obtains abundant opportunity to observe that the white specks, at first mistaken for pollen or other foreign intrusion, have a motion equal to several inches in a short time, and can be observed in the still water moving in various directions, some apparently with a revolving motion, and others without visible action. Many have advanced the spontaneity or protoplasm theory concerning the protozoa, which is a subject of much discussion, and lately a prominent German savant has advanced the theory that this element is the primitive origin of all life--vegetable and animal-which now exists upon the earth. A somewhat startling theory, but that life must necessarily have started upon this once molten mass in a very primitive form is clearly evident; but how, may or may not be solved.

Trout are not migratory in their habits, although in exceptional instances when disappointed in love affairs and driven away by successful rivals, or from a natural excess of love adventure or physical disturbances, will roam about, and oftentimes in such cases will take extended departures; otherwise they will frequent the 


\section{A Sportsman}

same feeding grounds, although taking their spring and autumnal outings. We all know of the particular fellows which are found year after year in the same deep pools and by the steep rocks, which so long bid defiance to human art, but which finally yield up their liberties and lives to their unconquerable taste for the insidious fly.

For years after years I have seen trout, so marked by their size or peculiarities as to be unmistakable, come annually to the same spots and defy all fair efforts against their privileges. In vain are the most dainty flies of all colors and sizes flaunted in the air, and ripplekissed, on surface and beneath, live bait, fat worms, and other delectable morsels. And these large fellows do not, any more than their lusty prototypes, when they have once taken possession of a first class domicile, allow of the invasion by other trout of their habitation, unless ousted by superior prowess. This occurs often in the season of amatory dalliance, when two are considered sufficient company, and when eternal vigilance is found to be an essential of satisfactory housekeeping, and where robbers and tramps have to be continually chased and banged at.

Nothing can be more comical and amusing than to witness the watchfulness and incessant unrest of a worthy burgher of mature years, who has taken unto himself a helpmate to regulate the domestic routine of his establishment, and to whom he has promised immunity from outside prowlers and sneak thieves: good-natured fellow, who has grown corpulent and high-colored from numberless golden chubs, striped minnows, and viscous suckers, which his vigorous 
activity has secured. Now will he forth for a season in a more highly oxygenized element; he will hie for the rushing waters, and promenade among the belles of the high world. So dressing himself in his gayest colors of red, white and orange, with many delicate tinted shades and sheens, and touching up his carmine spots, he sallies forth on a rollicking tour, which leads to speedy subjugation. No lover can be more complacent and attentive than he, none more willing to shoulder the matrimonial noose, or more fiercely jealous of the intrusion of others. It is amusing when mated to witness his torturing anxiety at the approach of other trout, and his inhospitable reception of them, which is indicated by his advance toward them with open mouth. The small trout and chubs cause him no end of trouble, and he has no rest night or day. No sooner does his mate indicate her intention of depositing an egg, by her movements before the deposit, than several active chubs and small trout appear on each side eager for the delicate morsel, and while those on one side are dispersed, another daring rogue from the other side rushes in and secures the prize; and thus it goes on in particular instances throughout the spawning season, and it may be doubted if a single egg escapes to a hatching on some spawning beds. This destruction of eggs by trout themselves is a very serious evil, and is shared in by chubs and suckers, and the attending male is often charged with a taste in that direction, and often when caught about the spawning bed is found with spawn in its stomach. I incline to doubt, however, if the full-charged and dispensing milter is guilty of this action, and probably not in the last stages of amatory play, as he is then 
very thin and flat, with most intensified colors, and when so caught has almost invariably an empty stomach.

I have observed the spawning trout on the beds a great many times, about the shores of the lakes and ponds, in the late autumn on clear, still days, and in November and December through the ice. The latter observation is the most satisfactory, and is obtained by cutting a hole a foot or two square through over the spawning beds, which may be but two or three feet below the surface. By placing a blanket or two on the ice for reclining upon, and by placing another over the head, shutting out the immediate light, the trout can be observed in full play. The disturbance occasioned by cutting and clearing out the hole is over in a few minutes, and the trout below soon become entirely fearless. On some beds the spawners seem to be without particular mates, having a half-dozen or more cavaliers in attendance, whose amatory distractions donot seem to interfere with their appetites, and who indiscriminately make a grand rush for the eggs as soon as deposited, and it may be that there are several spawning heaps or beds immediately adjoining and half a dozen spawners at work, attended by a dozen or more males, who apparently secure every egg for digestion. I have sometimes seen fifty and even a hundred trout thus congregated in an area not over ro ft. square, and in such close proximity that there was hardly any intervening space between them. The spawning beds are generally composed of a slightly raised mound of gravel two or three feet in diameter; sometimes the beds are on the clean sands, without any coarse gravel whatever; sometimes among pebbles and a bottom grass.

The spawning beds often receive a hard scouring for 
eggs after the spawning season is over. It is not uncommon in the late autumn before the ice makes over the deserted beds, near the shore, to find half a dozen speckled chaps digging over the bed for some egg which may have escaped observation. It is not uncommon to see them digging into the beds from a horizontal position with their heads down and their tails flapping above the water surface, which occasions the first observation. Last of all comes the Chinaman of the lake, the sucker, who works patiently at lower wages than the dominant race, who with his porcine snout makes havoc with the bed, and fairly roots it apart for the last lingering morsel which remains.

Probably nine-tenths of the Rangeley trout spawn in still water, where a moderate freshening occurs from springs. The same quarters will be occupied year after year, unless physical changes occur.

Nearly all the trout spawn between the middle of September and the middle of December, although exceptional cases occur throughout the year, and there is no time during the year but what trout can be found in spawn in a form of more or less development. I have observed them through the ice spawning well into January, and not very long ago I caught a 7-pounder in the first part of August which was full of ripe spawn, and dripping. This fish was caught at a depth of about $30 \mathrm{ft}$. on a slow troll, with a heavy sinker, with a No. 2 fly. I know of a good many spawning beds about the lake and ponds where after the ice first freezes over I have taken much interest in regarding the trout below. One of these, situated opposite a landing at one of my adjunctive camps on a pond, I had an amusing incident when accompanied by an enthusiastic friend and sports- 


\section{A Sportsman}

man, Col. H. C. Nutt, one season after the ice had freshly made. We had skated up the lake five miles to take our lunch there. The Colonel regretted the passing of the fly-fishing season, of which he was an ardent votary. I said, "Well, you shall have some if you want." He said that that was not possible, as the waters were frozen over. I rejoined, "Nevertheless, you shall have some." He was incredulous, and offered to wager that he could not. "Very well," said I, "but I don't want to win your money on a sure thing; but I will wager you a big cigar or a box of cabman's thirds that I will take a trout with a fly right here from the platform in front, and put him in your hands within five minutes from the time I commence fishing." This offer was taken. I then had my man go in front with an axe and break up the ice, which was between 2 and 3 inches thick, over a space of ro by 15 feet. Then we put in a boat from an adjoining cover and rocked it in a violent manner, driving the ice out of the broken place, some over the ice and some under. We then went in for lunch half an hour, and after I reached down a fly-rod, equipped, from over the door and cast, the Colonel standing with his watch in hand. On the first cast my trout struck, and in three minutes from the start I placed a third-of-a-pound trout in the Colonel's hands. I let the Colonel go on then, and he caught with his plain fly from twenty-five to thirty trout in a short time. The water where we fished was not over 3 or 4 feet deep. The trout were of moderate size, the largest not being over half a pound. The spot I had long known as a favorite spawning ground for small trout, and perhaps over a hundred were left there. 
I think the trout in the Rangeley Lakes, excepting the Umbagog, are about as plentiful as ever, although the raising of the waters has changed their spring and autumnal habitats a good deal, and some of the old fishing places are of the past. Trout Cove in the large lake above the Upper Dam was a spring fishing place for a period of ten or fifteen days, where in the gentle current one could satisfy his most ardent passion for trout, and become fairly surfeited; that is, if one could ever become completely surfeited with fly-fishing.

Not far from Trout Cove was the run below the old, now submerged, stone dam, which for large trout in the autumn surpassed any spot I ever knew of. I used to have the fishing there alone and unrestricted to my heart's exorbitant content, over twenty years ago, when there was scarcely another rod going. Day after day I fished it in the height of the season, wending my way to it a mile through the woods by lantern light to get the first fishing of the blushing morn; and after resting through the day I would take in the evening fishing, and wend my way home an hour after dark by the same light which had guided my morning footsteps. Sometimes I would get hold of a big fellow after dark, which would so tire my patience that I would feel like straining my leader to separation.

The water there ran dark and smooth in a passage of 30 or $40 \mathrm{ft}$. wide between large rocks into a pool of several acres in area below. In the passage and below were the leviathans of the deep. Now of late years, the lake, raised I 2 or I $5 \mathrm{ft}$. higher, has destroyed the current, and made a sea of the locality.

Some days one might whip the run and pool for hours without a rise, although gigantic breaks about might 
occasionally be observed, but the favorable hour in the right season was sure to reward the seeker. Once I caught the pool on a day of high carnival, a day of exultant joy, of moving and commotion among trout, which on some days and occasions exhibit an eager recklessness, and are fearless and bent on destruction. It was a cold, blustering, gusty day, with occasional sleet, late in September, when I had to go back frequently to a fire on the shore to thaw out my benumbed hands. At intervals the water boiled about me with swirling breaks, and visible currents of pursuing fish. My first cast, a short one, scarcely Io ft. away, responded with a 5-pounder in an instant, and I begrudged the time it required to bring him to net. Another and another rose in succession to my fly, which scarcely flecked the merry ripple tops ere it was taken. No under of fly surface draw seemed required for my first few fish, and I screamed with delight at each strike. My third was an $8 \frac{3}{4}$-pounder and the largest of the day, and the smallest was $3 \mathrm{lbs}$., and my total catch ten fish, which weighed $57 \mathrm{lbs}$.

I secured all alive in two large cars I had at the run, excepting the largest, which was gilled, and on the following day weighed the balance and gave back to the pool all but three, which answered any use I could have.

The largest trout I have seen after being caught weighed almost exactly i $1 \mathrm{bs}$., although there are wellauthenticated instances of trout which have been caught weighing $\mathrm{I}_{2}$ and $\mathrm{I}_{5} \mathrm{lbs}$., and Io-pounders have been taken in several instances. The largest I have ever taken weighed $9 \frac{1}{4} \mathrm{Hbs}$. and the second largest 9 tbs., and I have taken a good many from 7 to a little over 8 1bs. 
I once secured a $9 \frac{1}{2}$-pounder from the apron below the Upper Dam some fifteen years ago, which came over the fall of the dam above and was left dry on the apron logs. The logs of the apron were separated somewhat, allowing the water to pass through as it flowed over the dam. I was some distance off, and saw the commotion on the apron, which I first thought was my Skye terrier at play, as he frequented the spot; but succeeded in arriving at the apron and in securing the fish as he had almost reached the end of the apron and was about to drop into the water below. I have seen eels of Io and I 2 1bs. weight caught securely between the logs of that old apron, which came over the dam at night, large, lusty, black-backed and yellow-bellied fellows, which had doubtless done their share in ravaging the lakes.

I remember well this large trout, the II-pounder, which for several years in the autumn came to the same place in a moderate swirl of water above a dam, where in his mighty solitude-for he seemed quite alone-he would signify his presence occasionally by an uplifting at the surface which would make an angler's heart quake. He became the target of many ambitious efforts, both of fly-casters and bait-dabblers, but maintained a dignified and conservative indifference. In a quiet surface and with the sun's rays in a favorable quarter he was often observed either in quiet meditation or slowly taking his constitutional promenade. In vain were flies sunk for his convenience, and equally vain were the tidy worms and natty grasshoppers trailed before his majestic presence. Some vowed he was $3 \mathrm{ft}$. long, that his mouth was large enough to take in a black duck, and 


\section{A Sportsman}

that he must weigh I 5 tbs. Well, he was taken one day by an old guide, who would have scorned to have taken him any other way than fairly, but most curiously he was taken while everybody was at dinner, and according to the guide's account he had allowed his wormbaited hook to rest on the bottom for a while, from which it was seized by the old patriarch, and in natural sequence completed his foraging adventures and he soon lay gasping on the green grass. He did not prove to be $15 \mathrm{lbs}$. in weight, or $3 \mathrm{ft}$. long; in fact, was a very short trout for his weight, measuring exactly $27 \frac{1}{2} \mathrm{in}$. in length, and of magnificent color. His photograph, life-size, is before me.

A remarkable and well-authenticated catch was made by my friend the Hon. H. O. Stanley, of Dixfield Me., some years ago, in the large lake, of five trout in one day, and all with a fly, which weighed 42 tbs., the largest weighing Io $\mathrm{Hbs}$. and the smallest $7 \mathrm{Hbs}$. It is doubtful if this catch with a fly has ever been exceeded by any fisherman at the Rangeley Lakes in a single day.

We find in men the characteristics peculiar to climate, soil, and food. So with trout, excepting that they show much more prominently than with the human race the disparities occasioned by their surroundings. Once when fishing through the ice for several days with a friend at a certain place on the lake where we had remarkably good luck in getting short, thick trout, and which place, by the way, produces the heaviest trout in the lake for length, and after pulling out a fat 4-pounder which hardly measured I 6 in. in length, I remarked to my friend that he would probably be surprised to catch a $I_{2} \frac{1}{1 b}$. trout which would exceed the 4-pounder in length. In demonstration of this we set a dozen lines in $30 \mathrm{ft}$. 
of water, by an island where above all the places in the lake I had observed the trout to be very long and slim, and where the color indicated most positively that the bottom was not only very muddy, but extremely dark. Here we caught fifteen or twenty trout, which were invariably slim and eel-like and black-bellied. Among them were several running from I to $\mathrm{I} \frac{1}{2} \mathrm{lbs}$., which were not less than from $I_{5}$ to $I_{7}$ inches in length. In that locality it is unusual to catch any trout of great weight, although I once caught one there of the most unusual weight, long, slim and dark, which was the longest trout I ever saw, measuring 30 inches in length and weighing 7 1bs. He was an old one and evidently dying of old age and lack of food, which his waning activity failed him in gaining. A short time ago a lady, a friend of mine, caught a plump 8-pounder, which measured exactly $23^{\frac{1}{4}}$ inches in length, which was caught in comparatively shallow water in a quarter where I have taken thousands of trout, but where I have never known a slim black-bellied trout to be taken, not even a stray, though often strays are picked up. I have often taken trout which I knew had arrived where caught, within twenty-four hours, from a distance at least of two or more miles, having the markings in color too strong to be ignored, and which had not been long enough at the new place to get fitted out in the prevailing garb.

Inexperienced fishermen may think this somewhat improbable, but men with whom I have almost yearly fished for the past thirty years will recognize the features I have illustrated. We often remarked to each other, "That is a cedar tree trout," or a so and so trout, and probably correctly. Why trout will remain about 
one place for life is difficult to explain; but they do. And so we may say about men. Why will they stay in one place and eke out an uncertain and precarious existence, when they can go where they could do so much better? I often think of this while I am travelling about the world and witness the prosperity of some localities and the misery of others, and find humanity pleased and satisfied in each place. No matter where I go it is mostly the same with the inhabitants, lauding the respective merits of their region and claiming advantages not possessed by others; and so they stay and die, and their children grow up after them and follow in the footsteps of their parents. And so it is, I presume, with the trout. If they could talk and express themselves and be understood, it would probably be found that they had very good reasons of their own for continuing where they could not be otherwise than slim and black, when they might go where they would soon get fat and mellow with unctuous delicacies. Occasionally a trout strikes out, as with humanity, and never returns, linking his fortune with another colony, and unknown evermore among his old friends and relatives.

Trout are well protected and plentiful, and no season has been better than those of late years, and if the fishermen who display their skill at the Upper Dam during the season could see the large trout on the spawning beds in October and November they would hardly expect any diminution of the noble fish in the immediate present. The water below the Upper Dam when drawn down after October I, and the shallows below, are covered with large trout of $4,5,6$, and 8 1bs., that make great commotion and exhibit their immense 
backs and tails with prodigal profusion. Ornamented in their highest colors, they present a most fascinating sight; now swimming along in pairs at a slow pace, then whirling in great eddies, then ploughing across reaches with speed and streaming wakes.

With cautious steps they can be approached to within Io or $15 \mathrm{ft}$. and most closely observed, and if disturbed and driven away to deep water will speedily return.

I have never in many seasons seen the beds below the Upper Dam more fully occupied by large trout than in late years. Many believe the trout to be less plentiful than before, and prophesy that in a few years troutfishing at the lakes will be a feature of the past, but I do not agree with either opinion, and my annual experiences extend over forty seasons.

Although many trout come in at known fishing places they bear but a small proportion to those in the lakes. They are well distributed, and the favored fishing localities but few. Probably nine tenths of the trout have their spawning beds in retired places, in comparatively still water and entirely unknown to the average visitor.

I think next to man the blue heron (Ardea herodias) is the greatest destroyer of trout at these lakes. This bird is an incessant nocturnal as well as daily feeder, and of inordinate appetite, and although its principal food is chubs and frogs it destroys a great many trout and will get away with $\frac{1}{4}$-pounders, if not larger. They will have no hesitancy in striking and fatally wounding trout of over I1b. in weight. Yearly I see trout swimming about which have been struck and pierced by this bird; lately I caught two which were unfit for food, each over I $\mathrm{tb}$. in weight, having holes in the back nearly 
through them as large as pipe stems. It may be a question if this bird, of which hundreds frequent the shores of the lakes from the early spring to the ice, do not in the aggregate kill more trout, principally small ones up to $\frac{1}{2} \mathrm{tb}$., than all the fishermen. Aided by the loons, kingfishers, and mink, they undoubtedly do. The mink is a voracious feeder, and will destroy large numbers with the greatest ease from congregating pools and the breeding streams which feed the lakes.

A mink will kill a dozen trout in a day when they are easily accessible, eating only the heads and leaving the bodies to decay. If one can get into a fisherman's car it will strip it clean of trout in a single night, even if there are several dozen, and carry every one off.

I had a car, which was accidentally left open, stripped one night of a dozen trout weighing from I to $2 \mathrm{fbs}$. It was a very large car, having but a small opening in the top, of about 8 in. square, and was but half submerged, leaving fully I ft. of raise from the water to the exit aperture. I could hardly see how so small an animal as a mink could haul out trout weighing more than itself; but a few days after, when I had replenished the car with ten or twelve more trout, one or two of which pulled above $2 \mathrm{lbs}$. and one nearly $3 \mathrm{lbs}$., I saw how it was done. I was sitting upon the shore when I observed a commotion in the car scarcely $40 \mathrm{ft}$. from me. It was covered, but the trout were splashing about at a great rate; and presently I saw a mink appear on one side of the box, swimming about and beneath it, endeavoring to find entrance. I watched him for some minutes with great interest and amazement. He would swim around the box several times, then beneath, then crawl up the sides and inspect the top, then 
dive down beneath again and appear upon the other side, then hesitate on top apparently for reflection, and then in the most active manner commence his journey around and about the box again. He paid no attention to me whatever, as I remained perfectly quiet. He finally dived into the water and disappeared. Interested to know how he would act in taking the trout, I took advantage of his absence to go to the box and remove the cover, and returned to my previous sitting place. In a few moments I saw him appear at the box again; he swam about several times before mounting. On top he immediately discovered the opening, down which he disappeared. At first I thought I would run up and replace the cover, but then it occurred to me that I should perhaps catch a tartar; and besides I wished to see how the work was done, as I had been the victim of several losses of this character. The splashing in the car indicated his entrance, and in half a minute he appeared at the top dragging out a struggling $\mathrm{I}-\mathrm{fb}$. trout. But the struggles were comparatively faint, as the mink had evidently given the fish a distinctive quietus. Down into the water he slid and disappeared. I saw him soon appear along the shore above, when I lost sight of him. In less than three minutes he appeared again at the box and repeated his first act with a second trout, which he disappeared with as before, and returned after about the same lapse of time. The third act was more prolonged, as he attacked the largest trout in the car, heavier than himself, but finally dragged it out and carried it off. I concluded it time to put the cover on the box and end the play, well satisfied that otherwise all the trout would soon disappear. 
The trout of the Rangeley Lakes probably average larger than from any other waters. I should estimate the average weight of those caught in the lakes at a pound. I have not kept any particular record of my catches of late years, but did until some twenty years ago, when I had a record of over 6000 trout, which averaged over a pound, but my catches then included those of winter fishing through the ice, when the lakes were but little visited, and before it was any infraction of the law to so fish. I was very fond of those excursions of two or three weeks at the lakes, with trout for the object, and the auxiliaries of the robust open-air life, the shooting, skating, and other sports.

With a few companions, we would have no difficulty in securing an average of fifty pounds of trout a day, which, well frozen up, were carried out for distribution among our friends. These winter trout would average a full pound and a third, seldom taking under half a pound, and up to an occasional seven- or eight-pounder.

I have given considerable attention to the freezing of fish, especially trout, during the winters when I have been at the Rangeleys, during former years, when the season was open for winter fishing through the ice. Insensible to cold as the Rangeley fish seem to be, they will invariably die in a short time when confined in a car and pushed down under and next to the ice, while they will live a long time in a weighted car if sunk to the bottom. The sluggishness of the trout is clearly apparent in the last part of the winter, and I have often caught them in this advanced condition, when I have wondered at their ability to take the bait. I am of the opinion that many of them go into the mud along-side the other fish. 
In December and January there is a notable scarcity of live bait, and in February and March they are very difficult to find, although I have sought for them in dozens of places, both in deep water and shallow, and those places where I have taken any in the late months were in the vicinity of springs, and hardly any to be obtained, excepting in the early hours of the morning and those preceding sundown. I have frequently had to go out fifteen or twenty miles in the adjoining country and fetch them from spring holes. Yet the trout caught are seldom empty of small fry or chubs, and it is quite likely that the trout root them out to a considerable extent from the mud; and that trout do root in the mud a good deal is indicated by the earth and often lumps of clay found in their stomachs. I have caught large trout often with a small handful of clay balls in their stomachs, which have remained after the probable exudation of loose earthy matter. The parasites attached to trout fins, so noticeable in the winter and early spring, and which soon disappear in open water, indicate their earth-frequenting. While in December and early January the trout are comparatively plentiful in a few feet of water below the ice, they are mostly off in from $\mathrm{I}_{5}$ to 40 feet of water afterward, but I have seldom found them below 50 feet. In winter they are mostly at the bottom or within I or 2 feet of it. In this season the contents of their stomachs are quite miscellaneous - glutinous ground feed, chubs, varieties of small fry, rarely blue-backs, and suckers.

The results in freezing I have so far obtained are as follows, relating especially to trout:

That trout may be frozen solid without destroying life. 


\section{A Sportsman}

That they may be fully resuscitated after several days' freezing.

That they must be frozen quickly and at a temperature equal to ro to I5 degrees below zero.

That while frozen they must be completely protected from the sun.

That while frozen they must not be submitted to a temperature below zero, but in one sufficient to prevent any thaw.

That in resuscitating in water an abundant supply must be given.

That the water must be at a temperature of from 32 to 35 degrees.

That the temperature of the apartment must be kept at about the same level.

That the thawing must be so regulated that from 25 to 30 hours must be given before the fish is restored.

Upon being numbed and frozen quickly before life is seriously affected by exposure out of water, and kept and thawed as mentioned, they will resume their natural and normal condition, and when returned to the lake will swim off at a lively rate. The commoner kinds of fish may be frozen and restored with much less care.

The bull-heads or horn-pouts, which have a great tenacity of life, may in cold weather be frozen up and thawed out to life very readily. I remember an instance of some being caught in another locality from the lakes, where they were left carelessly on a boathouse floor, and speedily froze up together, which in a week afterward were, all but one or two, fully restored to life and activity by the cold-water cure. The bullhead is a good liver out of water if kept moist and cool. 
I well remember when a boy catching them on a misty night, and after leaving some of them in the wet grass behind me finding them alive in the morning.

Most fishermen are familiar with the marsh grass chub netted along the sea-shore, which retain life so long out of the water. In former years, late in winter I have frequently carried them up to the Rangeleys for live bait, packed in cigar boxes, with flannel between layers. They will keep lively for some days if kept cool and put in water over nights.

I am of the opinion that all kinds of fish in the lakes hibernate more or less as frogs do during the winter months, and certainly become dormant to a considerable extent; and I do not doubt that trout in a limited way go into the fluffy mud somewhat as about all the chubs and small fry do. In the open season the waters fairly swarm with the latter, while they are difficult to find after January.

Trout stalking when the conditions are favorable may be accounted the most fascinating, exciting, and artistic method of taking the speckled beauties.

The season in the northern waters of Maine is September, when the summer heat is over, and when the cool days and nights have lowered the temperature of the surface waters down to $63^{\circ}$ Fahrenheit, and below; the field, that of a placid lake or pond where trout abound, when the surface is entirely smooth, or agitated only by faint ripples.

The afternoon is more favorable than the morning, although some days are throughout favorable.

With the above conditions, and a light boat and companion guide at the stern who can skilfully propel the boat over the water with scarcely a ripple from the 
paddle, and with a light casting rod of good length, and a light leader and a No. 8 or ro fly, and a landing net, one is equipped for the sport.

It may be sunny or not, overcast or clear, it matters not if the wind is absent or light, but on a bright or sunny day the necessity of skilful work is more apparent than when the sky is overcast or dull. When the sun is shining or partially obscured, the boat should be worked between the sun and breaks, to the advantage of the fisherman and the disadvantage of the trout. The effect of shadow is light compared with the advantages so gained.

Many of the lakes and ponds in Maine where trout abound are favorable localities for this sport, although all are not, and there are usually quite a number of days in September when the temperature of the surface water and other features are entirely favorable.

I will confess to have allowed some decades of fishing experiences to pass before I became familiar with this sport, to which of late years I have looked forward with much interest and expectation.

The trout, which were plentiful near the surface from the going out of the ice until the middle of June when the surface water warmed up to a temperature of $65^{\circ}$, have sunk away to cooler depths, where they remain until the surface water again becomes favorable from the cooler weather of autumn.

But in surface stalking one does not get so large fish as in spring trolling, for it is the medium-sized fish that gives itself the frolicsome play of surface feeding, weighing from $\frac{1}{4} \mathrm{lb}$. to $2 \frac{1}{2} \mathrm{lbs}$., and, in the waters which I frequent, averaging a trifle over $\frac{3}{4} \mathrm{lb}$.

There are certain autumnal days when the conditions 
are favorable, when it would seem as if all the mediumsized trout in the waters were surface feeding.

Not in an eager and conspicuous manner with splashing breaks and flashing swirls, but in a quiet sucking in from the surface of the varied ephemera which plentifully abound, in a manner so quiet as to be observable only to the experienced eye.

No minnow, however minute, can agitate the surface of the water more delicately than a $\mathrm{I}_{2} \frac{\mathrm{Hb}}{\mathrm{tb}}$. trout, if he wills it, and he does when so feeding, although the occasional more conspicuous break and swirl occurs in the presence of an unusually attractive lure, apparent to the most ordinary sight.

Equipped, the boat is propelled deftly by its stern paddle over the feeding water. The fisherman is seated in the middle of the boat, casting softly to the right and left with the progress of the boat, for the advantage of a possible surface trout that may be about. A delicate apparent minnow break is observed off to the right, perhaps 50 , perhaps 100 or more feet distant, of which, as soon as over, nothing remains to mark the exact spot except a possible air bubble or two. The boat is propelled toward the side of it, to within 35 or $40 \mathrm{ft}$., when the cast is given over or near the spot. Perhaps the fluttering fly is taken at the instant of its fall, for the trout may be directly beneath, but generally not, for the fly is almost always taken below the surface, which position the fly will assume on a long cast and a slow draw.

The trout is likely to have moved Io or $15 \mathrm{ft}$., perhaps more, but he is almost sure to be picked up in the neighboring area if he has not been alarmed by unskilful movements of the boat or its occupants.

Often an active trout will be on the go as feeding, and 
by the time that the boat has reached a position for casting over the first break, a second will be observed still beyond a possible cast, presumably from the trout which made the first break, and before the second break can be reached a third appears still farther on, and sometimes so on; and I have often followed up and secured my trout which has carried me by a dozen breaks and fifty or sixty rods beyond the initial appearance.

Ordinarily, if a break occurs within a few boatlengths' distance, which can be speedily reached, the chances are more than half in favor of securing the fish. If within casting distance the fish is almost sure of being secured.

Often breaks will occur so near the boat that nothing can be done but for the stern man and caster to remain motionless until the boat, if under a headway, may pass on, when the chances are half in favor of the trout being picked up in the rear. If the boat is still, the chances of taking the trout are diminished, as the motions essential to shortening line and the proximity of the trout are likely to alarm the fish, and when alarmed he invariably strikes down. Occasionally the breaks are so plentiful that one may take half a dozen fish without moving his boat. I remember an instance a few years ago, when accompanied by an English fishing friend whose experience had been mostly in the dry fly drop of the Thames, where he had notable success, that we caught well out on the pond fourteen trout averaging nearly a pound in weight, without touching the paddle to the water, and my friend became exceedingly enthusiastic, which he well might be. 
This fishing must not be confounded with pool fishing, or that which we often find in isolated ponds which are unfrequented, and where the little chaps, entirely uneducated to the penalty of the hook and fearless, will crowd about a raft or boat until a hundred or more may be picked up.

The fishing I refer to is the stalking of the fish in well frequented waters, where they are sought and followed up under the peculiar conditions which regularly occur where the trout are scattered over the surface, and not in schools, and must be sought for by their feeding breaks; a fishing distinctive in character, and which I am sure is not extensively practised by all fishermen.

It is not probable that localities favorable for this stalking exist about all trout waters, but there are hundreds, I dare say, of lakes and ponds in Maine where it can be most successfully followed.

A habit I had much pleasure in, in winter was of watching and teasing the trout in the water below the ice. This I accommodated myself to by selecting a good locality for trout, where the water was not over 8 or 9 feet in depth, with a sandy bottom. Lying upon some blankets, with a single one over my head, and a hookless line with a small chub tied at the end and a sufficient sinker, I would bob for the trout, which after a while would come swimming along, and noticing the bait would, first indifferently, but afterward more vigorously, engage with it. By drawing away the bait at the critical moment, after considerable teasing, the trout would follow up the bait, it being withdrawn, and having a fair-sized hole of something less than a foot square, and two feet or more of ice, I would shortly 
get the trout up near the bottom ice, and finally, at a last excited dash, rapidly withdraw the bait, with my hand at my side. The trout, following to the surface in its excitement, would for a moment be too confused to dive below, giving me in that moment the opportunity to rapidly put my hands below and cast him out upon the ice, unharmed, but much alarmed. This may appear difficult to do, but it is really quite simple, and I have taken four or five trout in a forenoon from a single hole in this manner.

HOW FISHES FIND THEIR WAY IN THE WATER.

This subject has been a subject of much discussion without resulting in any definite conclusion to many.

One opinion given is that fish are directed by an observation of bottom ground, or other land guides, by depth of water, its temperature, etc. Temperature undoubtedly has a bearing on the subject, as fish seek and occupy zones most to their liking, of which a prominent illustration is shown by the Gulf Stream, inhabited by a class of fish which are not found outside of it, excepting in corresponding temperature.

All fish are cold-blooded, yet the cetacean family, comprising the whale, orca, porpoise, seal, and kindred, avoid warm temperatures and invade the most frigid regions. But the seeking by the anadromous families of their appropriate spawning localities when scattered about in the depths of the sea, and the directness of their efforts, has been a subject of surprise.

A conclusion generally arrived at is, that fishes are directed by instinct; by that mysterious inward impulse which, unreasoning, blindly directs its possessor for the preservation of its kind. True enough in the 
respect of propagation in the necessitated element of fresh water, which nature impels a seeking for at the appropriate season.

The question arises, how does the fish find its way to the fresh-water stream, as instanced by those which unerringly arrive at the locality where their young lives commenced. We will admit, a priori, that fishes do find their way in the water. It is my opinion that fishes find their way through the water by explainable methods, as readily as humanity does in a forest where prominent objects direct the way.

The sense of smell or a sense analgous to that is very strongly developed in fishes, especially in the Salmo family, with which I have had more experience than with any other. In the Salmo family and with many others there is a prominent line mark extending on the body from the head to the tail, which, when examined closely, exhibits a cellular structure apart from the adjoining body. What bearing this feature has upon the possessor is conjectural, but it may comprise a sense of communication which has not been estimated. There are probably other senses in creation which we do not know of, independent of the human category of five, which have a bearing little understood.

In the absence of a strictly appropriate designation I will define scent as the element of perceptiveness which enables fishes to find their way in the water, and I will present my views in support of that theory from such observations as I have experienced.

All fishermen have noted the rapid way trout have in expelling the artificial fly if not hooked, and the attractive way bait-fishing has of drawing trout from 


\section{A Sportsman}

a distance if followed in one place, the odor of which moving by slow currents reaches the perceptive organs of fish. Beyond this there is a condition of body which imparts to other fishes, and likewise attracts, that is inexplicable to our ordinary senses-that which is indicated by the members of a school of fish in keeping together, though often widely separated beyond any possibility of being aided by vision, conspicuous with porpoises, orcas, sword- and flying-fish and an endless variety of other fishes. Whales upon a uniform feeding route will be widely separated, and it is a well-known fact that the harpooning of a whale belonging to a school will be almost immediately communicated to the other members, separated half a dozen miles apart, as observed by whalers.

An eminent naturalist, Matthias Dunn, describes the lateral line as consisting in its cells of jelly or mucus, having patches of sensitive hairs here and there, as electrical implements pure and simple, inclosing the whole body of the fish, and says these cells are of the same character as those in the electric or stinging ray; that the fish brain is a magnet polarized by the influence of the peculiar structure of the lateral line, constituting a new sense which he designates as the electric dermal, which, he thinks, aids the migrating fish directly to its destination for spawning grounds or other localities. The latter conclusion may perhaps be of some doubt, though it may under natural laws guide the fish in response to magnetic effect from the rocks, sands and other elements.

Stahr, the naturalist, considers that the sense of hearing is imparted by the influence of the lateral line.

Fishermen have observed the feeding activity of 
salmon and trout before the commencement of a storm, the coming event being communicated probably through the lateral line. This activity may be the result of electric stimulus, or a provision of nature in communicating by wireless telegraphy the necessity of obtaining food or depth shelter before the effect of combating elements. That fishes have a limited memory there can be but little doubt.

Seth Green related in his hatchery experience of a pet two-pound trout in one of his hatchery pools, which, being so tame as to take food from his hand, would dart wildly away if approached with a fly-rod, although it gave no attention to a walking-stick waved out over the water. This resulted from Mr. Green's having once caught the trout on a fly-rod with a barbless hook. Contrary to this instance of memory I have often caught trout which had but a short time before escaped by the breaking off of the fly, or the leader, with the evidence of the previous hooking visible from the imbedded fly and perhaps with a dangling remnant of a leader. I have many times caught trout which had been hooked before.

I remember a visit a few years ago of a friend, George A. Hull, who fastened to a good-sized trout, between four and five pounds in weight, which broke away after being played for some moments when about to be netted, carrying off the hook and half of his leader. He estimated the trout as a somewhat heavier weight than it proved to be, and came in disappointed. In less than a quarter of an hour afterward I had this identical trout on my fly, and brought it successfully to net, verified by the indisputable evidence of the 


\section{A Sportsman}

particular lost fly and parted leader. This did not show much memory, and would shade the theory of Dr. Dunn that the primitive memory of anadromous fishes directed them to the particular stream of their early life, directed by the dermal sense in its magnet polarization as the needle guides the mariner to point of destination.

A. H. Gouraud, in one of his articles concerning the movements of shad to the Connecticut River from Long Island Sound, said they approached the mouth of the river from the east, but did not reach the mouth by direct course from the waters of the Sound, as the discharge from the river pursued a westerly course in its current, making a loop, so to say, and the shad took their course up the current of the river waters, thereby occasioning a distance of a score of miles more than would be required if the shad had gone direct. This loop course in the sound had been clearly defined by the net fishermen. This would indicate that the current of the river was the guide for the shad to follow. He adds: "This fluvial characteristic may be due to distinctive mineral particles which, retained in solution far out at sea, may be revealed to the delicate perceptiveness of the fish, and so guide it from the deep to its bourn."

I would add to the mineral particles also the vegetable, an important element, distinct, and noticeable by fish. It is the following of these elements that guides the fish, which may to an extent have an educated perception as well as taste. I have frequently found whole fresh-water clams up to two inches and over in length in the stomachs of trout, which are 
apparently easily digested, having been scooped up by an appetizing eagerness from the scent of the open clam.

It is doubtful if salmon depart far in the sea from the estuaries of their native stream, not beyond the reach of its diffused water, which they readily follow up on approach of their propagating period, from three to four years after their exit, as the salmon are not extensive travellers, as indicated by the results of seining, and upon the Pacific Coast it is evident that they seldom depart more than a hundred miles from their streams, and that their principal habitats are at no greater depth than from Ioo to I 50 fathoms. I could give pretty conclusive evidence of this from the observation I have made in this respect.

The Pacific salmon have their respective streams, and at their season of stream-ascending are generally distinct from any of the other several varieties, although not entirely so, being accompanied occasionally by derelicts from a kindred family.

I should consider it very improbable that a young salmon conveyed from one of the St. Lawrence tributaries to an European stream would ever find its way back to its native stream, as its connecting link would be lost, and should doubt the efficacy of its magnetic dermal sense to direct it there. It is possible that a salmon by its delicate perceptiveness may distinguish the diluted odor of its natal tributary in the general flow of its fresh-water stream,--else why should its ascending course be sustained short of its objective point? It is not likely it has any distinct memory of its early association in the tributary where the first year of its life was passed, and perhaps two years, though 


\section{A Sportsman}

the familiar flow of its water may be detected and appeal to its motive in pushing on.

Thomas Tod Stoddart, an English author-fisherman, relates that while fishing on a stream with spawn-bait during the day, at the close he caught several black-bellied trout not frequenting the stream, excepting in a muddy-bottomed pond connecting, situated between two and three miles below, which had undoubtedly been attracted to follow up the stream by the odor of the spawn bait.

My friend Walter M. Brackett, the veteran salmon fisherman and distinguished fish painter, with whom for nearly half a century I have compared fishing notes, is as strongly convinced as I am of the extraordinarily acute sense of smell possessed by the Salmo family, and relates in his own experience at his own Canadian salmon stream, where he has never used any attraction other than a fly, of noting large numbers of salmon and trout as having been attracted and drawn up from considerable distances down the stream, from a quantity of spawn being attached to the stern of a canoe fastened at the river bank above.

After the ice disappears in the spring, and at the spawning season, these habitating trout leave their localities more or less, but by no means lose their reckoning.

Trout, if removed from their habitats and dropped in any parts of the lake, will speedily return home; of this I have had abundant evidence. This is especially evinced during the spawning season, when trout taken away from a spawning bed will return with celerity. A particularly thin and slabby milter weighing about two pounds I purposely experimented with, by carrying 
him off into the lake a mile before liberating him from the towing car, and caught him at the first place again that evening. I liberated him the second time fully three miles away and found him the following morning at the old stand.

The general movements of the Salmo family occur in the night, as in ascending streams, however tortuous or difficult, lying by in the daytime. Their feeding also is done principally after dark, when they are more daring and predatory, and they do not assume their full night vigorousness in the dusky twilight, nor by moonlight, but in the darker hours, when their boldness is conspicuous, and will take the fly of sombre color in preference to one of white. I have wondered with their night adaptiveness of sight how little their day shyness is indicated, when I have frequently had them, in pursuit of small fish, dash up within hand reach on flat rocks or the sandy beach where I have been sitting.

The lake water appears uniform as does the sea to the casual observer, but there is a varying quality, and many currents in both. These qualities are not apparent to our coarser senses excepting in a very ordinary way, but the respiratory organs of the fish, the gills, etc., may be keenly sensitive to conditions of temperature and water admixtures, even as our sense of smell detects the faint odor of smoke in the country fields or forest. The different qualities of water in this lake of six miles in length which I inhabit now more than others, are quite apparent to my taste, and I have often remarked the odor in drinking water from the sheltered coves, arising from vegetable matter; also in that taken from a forty-or fifty-foot depth. 
Every stream or rivulet which empties into the lake has a distinctive taste, apart from the others, stamped and impregnated with the quality of the ground and foliage through which it makes way.

The ice indicates perceptibly to the eye the prominent instances in this respect; currents imperceptible to the eye are constantly moving in various directions, and are the directing signboards for the fish.

Fishing on the California coast with fresh fish bait, I caught some hundreds of salmon by trolling with a light steel rod and 600 feet of line. I observed the following features: That as schools of salmon comprising many thousands came in from deep water, following up the anchovies, sardines and squid, which came in from spawning, they would at certain periods mostly all disappear, to be followed after a lull by other schools. I observed that the salmon would disappear a few days after a rise of water from either the San Joaquin or the Sacramento river, emptying into the bay of San Francisco, giving abundant salmon for the seining and canning works upon the banks of the latter. By the San Francisco papers the noting of the salmon arrivals would be four or five days after their disappearance from the Monterey waters.

The Japanese current known as the kuro siwo, the great current stream from the Yellow Sea, corresponding with the American Gulf Stream, pursues its way across the Pacific Ocean to the California coast, regulating the climate from California to Alaska as does the American Gulf Stream that of England, France, and Iceland; pursues its way north some 300 or 400 miles west of California until it reaches the long extending loop of the Aleutian Islands, which ends 
but a few hundred miles from the Asiatic coast. This loop of islands diverts the Japanese current inland and the stream curves in its route until it proceeds south along the Washington, Oregon, and California coasts; and the remarkable feature is presented of two mighty streams, but slightly apart, proceeding in opposite directions in greater volume than all the combined land rivers of the world could exhibit if united in one body.

The speed of this mighty current south opposite the outlet of the bay of San Francisco is estimated at between thirty and forty miles per day of twenty-four hours. Into this current pour the brackish and roiled waters of the bay.

The fresh water combining with the salt is quickly detected by the salmon a hundred miles below, and a general exodus of the salmon takes place, leaving but a few stragglers remaining.

In three or four days after their departure the canners on the Sacramento River are abundantly supplied by seiners.

Shortly afterward a fresh school comes in, which departs as those before after a few days following a fresh rise of the river waters, and appears as in the first instance a few days after their departure at the usual seining localities. These instances occurring several times during my fishing period plainly indicated to me the result of the river freshets. No mistake could occur in the identity of the particular schools in disappearing from the Monterey waters and appearing at the Sacramento River, as the same class of salmon known as the king or chinook, inhabiting the Columbia River several hundred miles north of the 


\section{A Sportsman}

bay of San Francisco, average about 22 pounds in weight, while those of the Sacramento and San Joaquin rivers average almost exactly i 7 pounds, as shown by the average weights taken at each locality.

No salmon-ascending rivers existing between the two mentioned points would clearly indicate the identity of the Monterey and Sacramento River class. So the salmon of the Pacific Coast go to their spawning grounds, never to return to the refreshing sea again; or if by chance a few should be able to, their bruised condition and totally impaired digestive organs result in but a brief existence. No authentic instance is known of a river salmon's survival on the Pacific Coast. If any had been taken they would show their identity by their disfigured appearance, which has never been observed.

In the banner year of 1902 , I 5,000,000 salmon were canned on the coast; yet no serious diminution in numbers has occurred, nor have the results of conducted hatcheries shown great success, despite the general opinion to the contrary. Therefore the great mass of salmon regularly taken may be assumed to be the progeny of those who sacrificed their lives for successors.

That electrical elements are prominent features in the denizens of the sea and fresh-water bodies, is clearly apparent and of undoubted efficient service, and may be a part of that element I have designated as scent, as a general sense which gives perceptiveness of fresh water in the sea, or of minerals and earth in solution, from magnetic qualities. This electric quality, or whatever we may choose to call it, we observe in freshly-caught fish which curl up and break in cooking, 
giving a feature not apparent when fish have been kept a day or two.

Eels display this element prominently, and also the bull-head or horn-pout. The marine mammals may receive large benefits from it in their long passages in the sea.

I am reminded of an account related to me by an English friend, of a pet seal owned by some one he knew who kept a lighthouse on the coast of England, which, captured when a cub, was domesticated with the family, being fed and allowed the range of the kitchen on the ground floor, to which the seal had ready access. This seal would make its way daily down to the water and pass many hours in the element, securing more or less food, but always returned to its place in the kitchen at night. Blindness finally came on with age to the seal, but it continued its journeys to the sea and, returned home as regularly as before. Complete blindness finally came to the seal, and, fully fed by the household, its visits to the sea became less frequent. As old age came on, it caused annoyance by its peculiar cry for food and lessened ability to get about; so much so that the family accounted it something of a nuisance, and, not wishing to kill it, arranged with a fisherman to carry it well off, some twenty miles away, and drop it in the sea, expecting it would naturally die in that element. But it appeared the second day after at its accustomed place. Another effort was made to get rid of it, by arranging with a sailing vessel to take it several hundred miles out to sea and then drop it in. This was done, and a number of days passed away without the seal. Six or seven days after, during the night, the kitchen maid, who slept adjoining the 
kitchen entrance, fancied she heard the plaintive call of the seal at the kitchen door, but being of a superstitious cast, and believing the call was from the banshee or bad spirit, covered her head beneath the bed clothes. In the morning the emaciated body of the lifeless seal was found at the kitchen door. The story may be authentic or not, but I do not consider its truthfulness to have been impossible.

The vegetable growth in the water, kelp, etc., and currents were familiar to the seal, and sight would have been of little aid to it compared with following the perceptions of its other senses.

Some naturalists have expressed the belief that fishes find their way to their spawning rivers or desired localities in a direct course by the pointing of instinct, and that alone. This conclusion does not seem to be well evidenced or satisfactory.

But the mysterious fish of the lakes is the blue-back trout (Salmo oquassa), entirely distinct from the Salmo salvelinus, with which it has no affiliation, being, strictly speaking, an arctic trout, which in some peculiar manner has found its way to the Rangeley waters, as well as to a few other northern lakes. As ordinarily taken they weigh about five to the pound, the maximum being near half a pound. The fish is quite distinctly a trout, with fine coloring and red spots. It has in contradistinction to the square tail of the Salmo family a swallow tail, and a blue back and exceedingly small teeth. The fish is long and slim for its weight, and for food purposes inferior, though claimed by many to be equal to the ordinary trout, but to my taste soft and muddy. One might fish the Rangeley for years and never encounter one or suspect its pres- 
ence, yet they exist in large quantities. Rarely-in fact I have never heard of but one or two instances where they have been caught with bait, and that in deep water. They are strictly denizens of the deepest parts of the lakes, and apparently subsist exclusively upon ground feed. This ground feed of the lakes is an important element with all fish, composed of insectivorous varieties and largely viscous matter, which settle profusely.

In the latter part of the month of October-from the 2oth to the 3 oth-the blue-backs find their way to the mouths of some streams, and ascend more or less into the quick water, where they deposit their spawn. Their appearance can be counted upon by the 24 th almost to a day, and the quantity assembled is immense, and in some instances so compact is the mass that barrelsful can be netted from a small space. During the brief period of spawning they are easily taken after dark from the shallow quick water by one wading among them equipped with a lantern and a hand net. I have often taken several hundred of them upon an occasion of this kind. Their tenacity of life I have noted as a peculiar feature, for I have had them out of water for several hours of a cold evening and fully revived some of them by placing them in a barrel of fresh water, where they have survived for several weeks, and in fact would have survived much longer but for the freezing up of the water. This fish would undoubtedly stand solid freezing under favorable conditions equally well if not better than the Fontinalis. The only one I ever saw out of season I picked up some years ago on the surface, which was in a dying condition, having been wounded evidently by a loon, as evinced by a large hole through its body. 


\section{A Sportsman}

They remain on the spawning beds during the nights of about a week in the latter part of October. The large trout often get among them on the spawning grounds at night and make havoc. One evening as I was wading with rubber boots, with lantern and net, I felt a heavy movement on my legs, and turning my light saw a large trout, which, I netted, weighing seven pounds.

Of late years the landlocked salmon (Salmo confinis) have become fairly plentiful, particularly in the Rangeley Lake proper, where first introduced, some twenty years ago, and also in the large lake, and in the Richardson Lakes. In the latter a member of my family caught one weighing seven and one-half pounds. The salt water smelt introduced a few years ago has increased extensively and extended rapidly to all the lakes of the range. This fish seems readily to habituate itself to most fresh-water lakes, and has increased to a very large extent in the Rangeley waters, although confined to a small size of three or four inches in length. Although large numbers are observed dead, floating upon the surface of the water in the spring-time, the increase seems hardly to be affected. This fish is apparently an admirable food for the salmon and trout, and in the spring would seem to be the principal food, as their stomachs seem to be crowded with them, and I have repeatedly observed from fifty to seventy in a single trout of large size.

I consider without question the smelt to be the most valuable fish for food stocking of fresh-water ponds and lakes.

The landlocked salmon varies in size largely in the fresh-water lakes where placed In the Sebago Lake 
they reach a weight in some instances exceeding 20 pounds, and in the Rangeleys they are often caught up to 2 pounds, while in the Schoodic Lakes, where they have been long domesticated, and where I have caught many hundreds, they seldom exceed 5 pounds. In California, near Point Reyes, in Crystal Lake, controlled by the Country Club, and where I aided some years ago in introducing the landlocked salmon, they gained most incredibly in weight in less than four years, from a few ounces up to 5 and $5 \frac{1}{2}$ pounds. In this lake the feed was almost entirely insectivorous, and largelyand in fact I might say almost wholly-the larva of the caddis fly, which abounded most plentifully, and which seemed to be the whole contents of all the stomachs I examined at various times. I regret to say, however, that the flavor of these salmon is distinctly off from any I have ever eaten, arising, I believe, from the almost exclusive diet. These salmon, however, will rise well to the fly, and are vigorously gamelike. Crystal Lake is infested also with a red salamander lizard, known as the water devil, quite common in California waters, and one of the toughest and most tenacious reptiles of the batrachian family, although quite harmless. These lizards are 3 or 4 inches in length, and swim rapidly about with the aid of their tails. Their skin and structure is so tough that it requires a very sharp knife to separate them, and they have a very tenacious life. I found one day on the shore of the lake a salmon between 4 and 5 pounds in weight, freshly dead, and upon examining it found one of these lizards firmly fixed with a deathly grasp in the throat of the salmon, likewise dead. It was plain enough that the salmon had seized the lizard and the latter had 


\section{A Sportsman}

secured his deadly hold in the salmon's throat, from which I had a good deal of difficulty in parting it. I was told by one of the cattle herders that he had seen other instances, and in his opinion the salmon fed upon the water devils and the latter in the lake had much diminished since the salmon had been put in. The odor of the water devils when cut up is very disagreeable, and it may be that this accounts for the inferior flavor of the fish.

While trout are fonder of insectivorous food in preference to any other, and it is a well-known fact that while growing will gain doubly in weight on this food over a fish diet, it is observable that a deterioration in flavor occurs from this exclusive food. I have taken trout in ponds at high altitudes in the Rocky Mountains, above timber growth, where such waters were hardly free from ice in July, where the trout food was exclusively insectivorous, and they were decidedly lacking in flavor.

This landlocked salmon is very gamy in action when struck, more so than the trout, and good eating in the Rangeleys, though in this respect not equal to the trout. The latter in my opinion are superior for eating over any from localities I know of, for trout vary much in this respect.

THE forests about the lakes are naturally adapted for deer (Cervus Virginianus), which have always been comparatively plentiful, despite the inclement winters and deep snows, and undoubtedly, owing to the rigid Maine laws, are increasing about the lakes, for the practically enforced regulations against shining and crusting give an opportunity to increase, and they 
do so slowly but surely when protected and free from wolves, as in this locality.

While I have killed many in this locality, I find that their shooting is attended with a great deal of exercise. I may not be a very good hunter, but I find that I have to travel altogether nearly fifty miles for every deer that I get.

It seems when I start out that I am likely to get a deer about every time I go, but I do not, nor one in a dozen times. But the interest is unflagging. The pleasure of being out in the forest compensates for all exertions, and exertion is a pleasure. The forest, never tame, is always exhilarating, and leads on with its varied attractions. With a good compass and a tolerable knowledge of the localities about, it is a supreme satisfaction to be alone for a while and to be lured on by a charm which is indescribable to those who have not experienced it.

The object which fascinates the mind is before you, no matter whether you accomplish it or not. It may prove aimless as your rifle with good opportunity, but little does it count, for expectation is rampant, and hope lures on to the satisfaction of wholesome fatigue.

Deer are often seen about the camps during the close season, and particularly about the ponds. At one fishing place, near a lily-pad growth which I often visit in the summer, I frequently find several deer about, and occasionally a doe with her fawn who retreat upon my near approach, but speedily return upon my departure.

We often notice the inclination of animals and birds to frequent the immediate vicinity of human beings, 
and invite their companionship, evincing a disposition to be friendly if they could, but, alas, too often compelled to pay the penalty of death for their temerity.

In the later season deer are doubly cautious and shy, and if observed browsing in the woods appear to be on the closest guard, and steal off upon hearing the slightest crackling of twigs or rustling of leaves, and generally before being observed by the sportsman. When lying down, they will often rest until sighting the intruder, sometimes allowing a close approach, expecting possibly to be unobserved, and when rising will immediately bound off at a rapid rate, and most adroitly take advantage of shielding trees or bushes to cover the retreat. Rarely they will stand a moment or so before the sportsman but generally bound off in the partially open forest, and occasionally, under favorable conditions, they are first observed. These are the opportunities sought for by the sportsman, and fortunate he is if his shot is a stopping one; for often, although fatally wounded, they will travel for miles.

I have almost always during my stay at the lakes in October and November during the open season taken in one, and sometimes two (the latter being the limit allowed sportsmen in one season). Last season I had a most aggravating incident, when I did not obtain a single deer. I had only one fair opportunity to shoot one, and that recollection is by no means satisfactory, for it was so fair and open that I could not have wished it better if I would. The conditions were very favorable, the ground and leaves moist, a darkish day, a gentle breeze, and myself approaching from the leeward. I was proceeding at the time down an old 
logging road which I had been on several times and where I had observed the tracks and indications of a very large deer. Proceeding along cautiously, as was my wont, looking at every spot where I was putting my feet, to avoid the crackling of a twig or decayed limb, and still looking ahead, I observed, perfectly motionless, not ten rods ahead of me as I turned an angle of this old road, one of the largest bucks, I think, I have ever seen, the one whose tracks I had observed. He was standing apparently clear entirely from the timber by the side of the road, broadside toward me, perfectly motionless, with his head and large antlers slightly turned toward me and gazing upon me with apparently the same interest that I felt in seeing him. Mentally I thought he was mine surely; with the rifle in my hand which had brought down several deer before at single shots, and with nothing distracting my view, nor troubled by buck fever, which I have never experienced, but as coolly and deliberately as I would fire at a target ten rods off, which was the distance of this buck, I brought carefully my rifle sights to a level, and without any haste, taking the most deliberate aim which was afforded by the opportunity, I fired. I fired at his body slightly back of the shoulder blades. It was a rough surprise to the buck. He turned, however, quickly taking his back track, and throwing up his signal flag of departure, which indicated that he was not hit, or at least had not received any wound of importance, and went off with bounds too rapid for me, owing to the then obstructing foliage, to get another shot. Astounded at my failure, I started after him, after having rapidly thrown another cartridge into the barrel of my rifle. I could follow 
him, owing to the condition of the leaves, without difficulty, but I found no trace of blood, and saw that he indicated no intimation of having been wounded. I returned to the spot where he stood when I shot, and there I found to my mortification and great annoyance a leafless maple sapling of about an inch and a half in diameter, which I had not observed when I fired, and at the level corresponding with the place which I shot at the sapling was shattered and nearly cut off by my rifle ball where its soft nose had exploded and become diverted from its passage in some direction away from the deer. This was the result of all my stalking, but it could not take away the satisfaction-the daily satisfaction-I had experienced. One must have an object for all exertions that is sustaining, and lends vigor and enjoyment to pursuits, which when aimless are of slight value.

The last two deer I shot I came upon unnoticed. They were standing a moderate distance off. It seemed a pity to shoot at them, so beautiful and innocent as they appeared. But I did. One was half broadside toward me, which I shot through the heart, when he dropped in his tracks, and perhaps was not conscious of his wound. The other was feeding, heading away from me, and I had to whistle for him to turn, and as he did, my bullet broke his neck. Last year, one day when I had hunted over a ten-mile tramp most carefully carrying my rifle in front, ready for immediate action, without seeing or hearing a deer, I approached within a quarter of a mile of camp, when I relaxed my careful walk and search, and threw my rifle carelessly over my shoulder. The forest was thickly grown, and as I passed a small thicket a deer rushed across my path 
within four feet of me, so that he almost ran over me; but he appeared so suddenly and leaped so rapidly into the thick brush that I was unable to unlimber in season, scarcely a second passing between his advent and disappearance. This deer had apparently been lying down when surprised.

One of our party had a curious experience two or three years ago in this locality. He shot at a buck a considerable distance away, observed it to fall, and when approaching discovered that in falling the buck had imbedded its horns in the ground and at the same time had thrust the front part of its head beneath a shelving rock, from which it was impossible to withdraw it, although the buck was not fatally wounded, having been struck in the shoulder, where the bullet remained, without passing through or breaking the bones. The struggles of the deer to disentangle himself were immense, but without avail, and his throat was cut after some difficulty. The deer's head was so firmly fastened beneath the rock, and so held by its horns, that after its death it was so difficult to remove that it could only be accomplished by digging out the horns. That the deer could never have liberated itself was quite apparent.

Several years ago, in January, while coming up the lake on the ice to camp, we observed something about a mile ahead, which we thought might be a broken bough, as they often blow out on the ice when it is clear. As we came nearer we observed it had some movement, and upon a near approach we discerned it to be a large buck, stranded by his inability to stand on the slippery ice. He made desperate efforts to get on his feet as we came nearer, but the 
moment he got up his legs would divide and down he would go. How he got out so far, at least half a mile from shore, was a puzzle, and indicated the great tussle he must have had.

He probably had stepped out at first from the woods on some snow ice, and made a little progress on the lake, when his footing gave way, and in his misguided, struggling efforts he had worked away from shore instead of toward it. He was pretty thoroughly exhausted, although belligerent toward us still. His efforts to get up were incessant, but his legs would divide in a moment, which must have been very unpleasant to him. We concluded to give him a new start in life; so, throwing a halter over his head, we dragged him over the ice with our young and well shod horse to the shore, and then by hand and other efforts some twenty feet inland. Even then he seemed unable to get on his feet, so wounded in sinews he must have been from his battle on the slippery ice. We held on, however, until he got on his legs, and saw him well off on his tottering limbs, although his progress was slow and undoubtedly agonizing.

We observed one day in front of camp an animal swimming in the water about a quarter of a mile from shore. Manning a boat, we soon overtook it and found it was a yearling doe, which after some exciting work, as the deer was very active, we succeeded in capturing alive, and brought it ashore. We confined it in an enclosure and supplied it with boughs to browse upon, and some boiled pototoes and oats, which it fed from during the first night, and fed regularly after, until we let it go back to the woods. It was very shy at first, but rapidly became tame, and when we let it 
go it seemed loath to leave, commencing to feed near as soon as liberated, and allowed us to approach closely, but gradually worked its way into the forest and finally disappeared from view.

An amusing incident happened to a friend of mine who had hunted most persistently without success. He wore glasses, without which he could not well see. While passing through a thick clump of tall bushes he was astounded by a terrific snort from a large buck scarcely five feet in front of him, which, facing him, accompanied his unmusical ejaculation with sufficient mouth-watering to becloud my friend's glasses beyond use. He was compelled to clean them, and when ready for action sought in vain for his insulting momentary associate, who had made good his retreat. My friend in relating his experience said, "I met a big buck today, but he spat in my face, and left. Confound him, I am going after him now, hot."

A lady friend at my camp a few years ago who had killed a deer concluded to go out after another, and did so, with a guide at a proper distance in the rear. She had gone but a short distance, but proceeding with slow pace and great care, when she was suddenly confronted from a clump of bushes near, by an enormous buck, which stepped out in a leisurely manner and stood for several seconds not ten feet off, there they stood gazing in astonishment at each other. Then with a few graceful bounds the buck disappeared among the trees. Upon relating the incident upon her return I asked, "But why did you not shoot him?", to which she replied, "I never thought of it. I wanted to see what he would do"-and she saw. 


\section{A Sportsman}

Deer, though often sought for most diligently, may be difficult to find, and yet may be stumbled upon at times quite readily. A few years ago a friend of mine lately arrived from England, went out with me early in the morning on October Ist, the first day of the open season, and being in advance of me, and not more than half an hour after starting, shot and killed two deer which came with a third running down upon him, thus completing his quota for the season.

Now, completing my sporting reminiscences, I have in view the writing of my business experiences. These, having been exceedingly varied in character and extending over half a century, will frankly exhibit the perils, with good and bad fortune, which have attended my ventures, from which now I am fully retired. 






ie 

